\title{
DAVID LIBESKIND
}

biografia de uma casa

Luciana Tombi Brasil

orientador Prof. Dr. Luis Antônio Jorge

Tese apresentada à Faculdade de Arquitetura e Urbanismo da Universidade de São

Paulo para obtenção do título de Doutora

em Arquitetura e Úrbanismo. Área de

Concentração: Projeto, Espaço e Cultura 
Autorizo a reprodução e divulgação total ou parcial deste trabalho, por qualquer meio convencional ou eletrônico, para fins de estudo e pesquisa, desde que citada a fonte.

Serviço Técnico de Biblioteca

Faculdade de Arquitetura e Urbanismo da Universidade de São Paulo

Brasil, Luciana Tombi

David Libeskind: biografia de uma casa / Luciana Tombi Brasil; orientador Luís Antônio Jorge. - São Paulo, 2019. 240 p. : il.

B823

Tese (Doutorado) - Faculdade de Arquitetura e Urbanismo da Universidade de São Paulo. Área de Concentração: Projeto, Espaço e Cultura.

1. David Libeskind, 1928. 2. Arquitetura moderna. 3. Narrativa. 4. Poéticas Visuais. I. Jorge, Luís Antônio, orient. II. Título. 
Para Vitória 
RESUMO 
O trabalho é um ciclo de vida que tem como ponto de partida e de chegada a casa do arquiteto David Libeskind, construída em São Paulo, no ano de 1961, visitada em dois momentos: a casa habitada (1961-2014) e a casa vazia (a partir de 2014 com a morte do arquiteto).

A biografia da casa proposta no trabalho remonta à organização biográfica da obra do arquiteto para propor um desdobramento da leitura da sua produção de modo a estabelecer relações entre a produção da arquitetura moderna e seu ambiente cultural, nas décadas de 1950 e 1960, a partir das inter-relações sugeridas sobretudo com dois destacados interlocutores: Joaquim Albuquerque Tenreiro e Alberto da Veiga Guignard. Para tal, convoca-se para essa construção o Libeskind arquiteto, designer gráfico e pintor.

Ao ampliar a interlocução com o debate contemporâneo - sobretudo através do método estabelecido de leitura no trabalho - procura-se contribuir com a construção da crítica historiográfica brasileira em referência aos elementos de natureza histórica e teórica.

Este método de elaboração pressupõe a leitura da coleção de imagens da referida casa em associação com outras produções em arquitetura, arte e desenho gráfico do arquiteto e de seus pares de projeto reconhecidos no trabalho, provocando diálogos que dirigem as narrativas verbal e visual. Desse modo, as operações sintáticas sugeridas apontam para o reconhecimento de um lugar próprio da produção deste arquiteto na arquitetura moderna realizada no Brasil, sinalizado na síntese revelada no trabalho como expressão poética e simbólica da sua produção impressas na sua própria casa.

Palavras-chave: David Libeskind; arquitetura moderna; casa; poética; narrativa verbo-visual; Joaquim Albuquerque Tenreiro; Alberto da Veiga Guignard; Brasil. 
ABSTRACT 
The work is a life cycle that starts and finishes at the house of the architect David Libeskind, built in São Paulo in 1961, visited in two moments: the inhabited house (1961-2014) and the empty house (from 2014 with the death of the architect).

The biography of the house proposed in the work goes back to the biographical organization of the architect's work to propose an unfolding of the reading of his production in order to establish relations between the production of modern architecture and its cultural environment in the 1950s and 1960s, from the inter-relationships suggested especially with two prominent interlocutors: Joaquim Albuquerque Tenreiro and Alberto da Veiga Guignard. For this, the Libeskind architect, graphic designer and painter is summoned for this construction.

By broadening the dialogue with contemporary debate - especially through the established method of reading at work - we seek to contribute to the construction of Brazilian historiographical criticism in reference to the elements of historical and theoretical nature.

This method of elaboration presupposes the reading of the collection of images of the said house in association with other productions in architecture, art and graphic design of the architect and of his recognized work pairs, provoking dialogues that direct verbal and visual narratives. In this way, the suggested syntactic operations point to the recognition of a proper place of the production of this architect in the modern architecture realized in Brazil, signaled in the synthesis revealed in the work as a poetic and symbolic expression of his production printed in his own house.

Keywords: David Libeskind; modern architecture; house; poetic verb-visual narrative; Joaquim Albuquerque Tenreiro; Alberto da Veiga Guignard; Brazil. 
ÍNDICE 


\begin{tabular}{ll}
4 & Resumo \\
6 & Abstract \\
8 & Índice \\
12 & Introdução \\
24 & Biografia de uma casa \\
31 & Primeiro ato: um projeto de arquitetura \\
52 & Visita à casa do arquiteto \\
89 & Segundo ato: arquitetura vivida \\
106 & Tenreiro e a ambiência moderna \\
131 & Terceiro ato: arquitetura em trânsito \\
150 & Guignard e as cidades que flutuam em névoas \\
178 & Interlúdio: a casa vazia ou a morte do arquiteto \\
191 & Último ato: arquitetura do desenho \\
228 & Textos, artigos, periódicos e sites \\
196 & Apêndice: desenhos arquitetônicos da casa \\
202 & Legenda e crédito das imagens \\
216 & Bibliografia \\
\hline 26 &
\end{tabular}




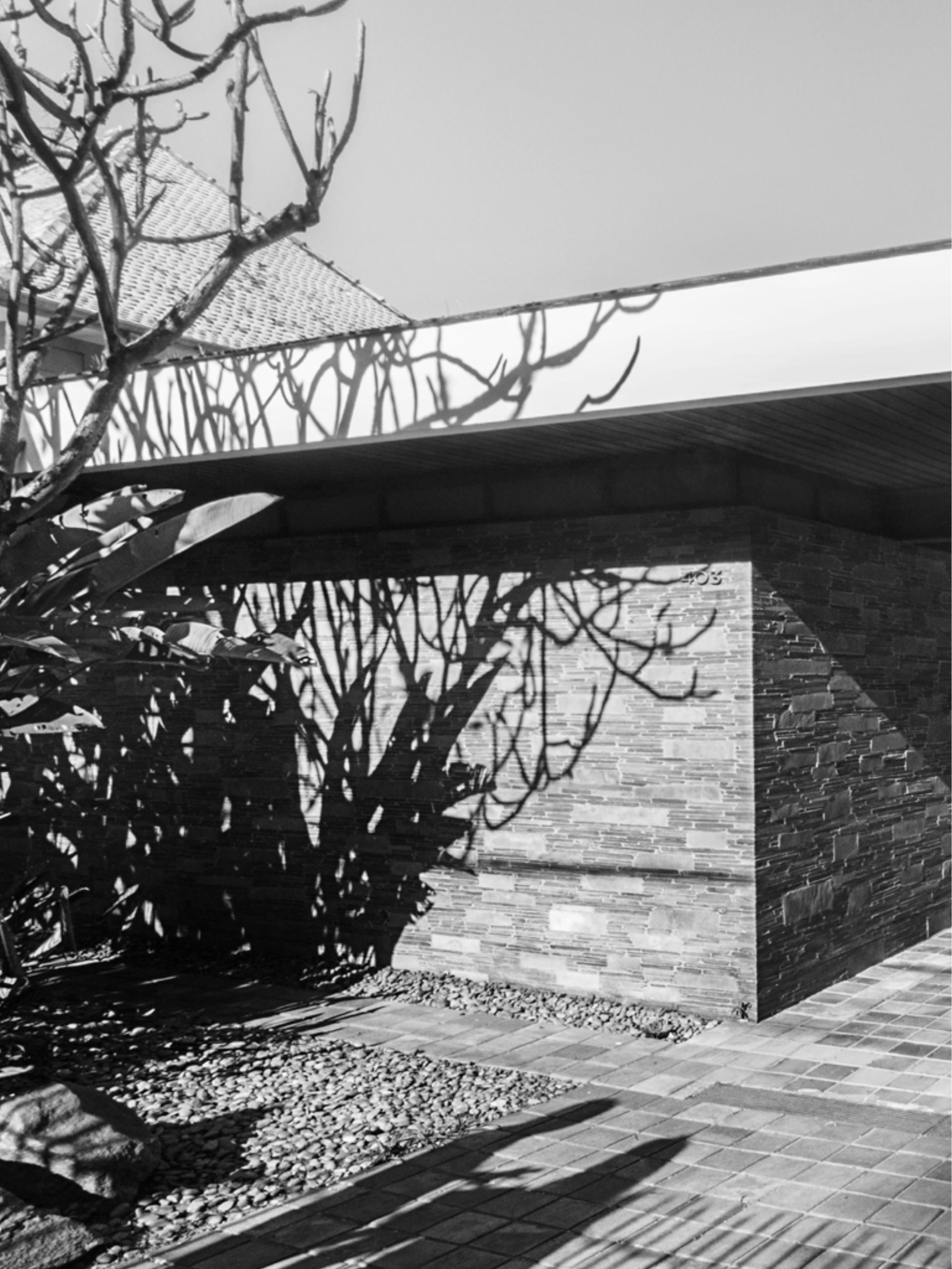




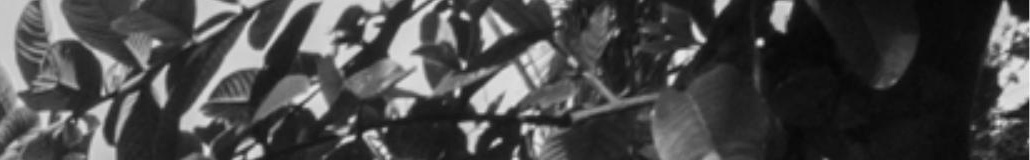

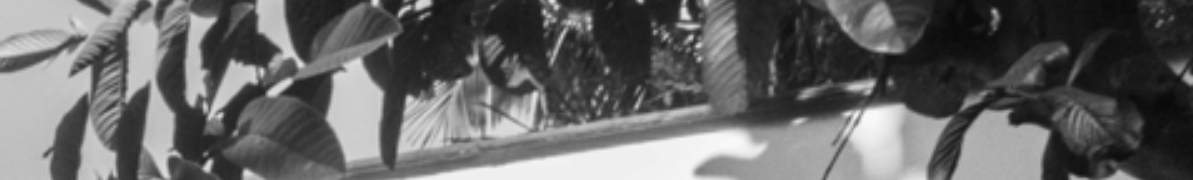

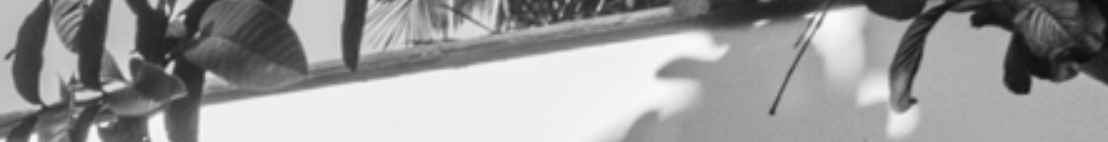

cons

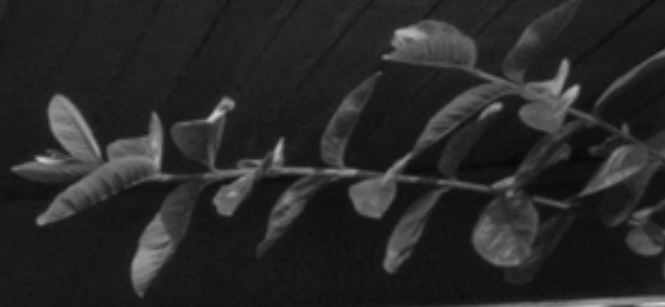

a. $=$

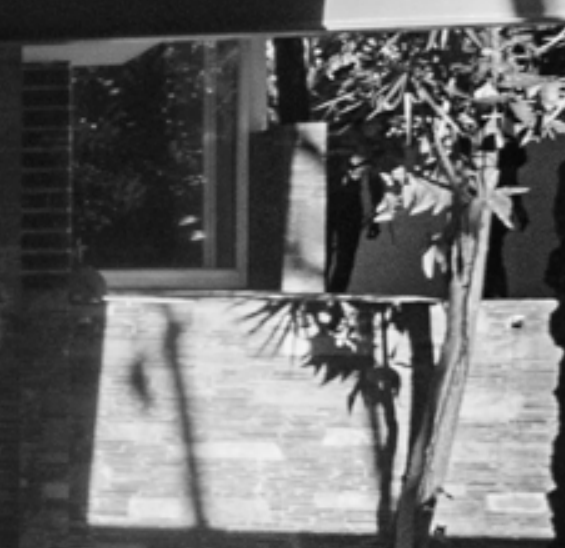

$2=-3=-2=$ 
INTRODUÇÃO 
“... é preciso saber se tudo aquilo que houve foi projeto ou destino, se

o homem construiu segundo os próprios desígnios ou se, pensando fazê-lo, fez algo que já estava dito e decidido. Fazendo a vida para nos subtrairmos à morte, fazemos realmente a vida ou fazemos, com nossas mãos, a nossa morte?"

Giulio Carlo Argan

O trabalho trata da biografia da casa do Arquiteto David Libeskind através do tempo em ordenamento não cronológico, o que permite olhar para parte da produção deste arquiteto de forma livre, propondo associações e analogias entre as várias camadas de ação durante a sua trajetória: Arquitetura, Arte e Design. Essa biografia de uma arquitetura, de um objeto inanimado revela a história da sua criação pelo arquiteto, a vida dos seus moradores, a história das coisas que a casa abrigou e ao abrigá-las modificou a si própria, numa eterna reconfiguração, ou ainda, como as coisas se completam mutuamente.

Parte-se do pressuposto de que há a estreita relação já esboçada na pesquisa de mestrado entre a produção arquitetônica e a produção artística, ambas amparadas por antecedentes de natureza histórica que se entrecruzam de forma indissociável na obra do arquiteto.

A reunião e a organização da obra de Libeskind outrora realizadas no âmbito da dissertação (2000-2004) na camada da historiografia, possibilitaram agora um mergulho de outra natureza, desvinculado da relação inerente a uma linha do tempo, mas que se ampara e se organiza em narrativas construídas a partir da leitura da casa do arquiteto em dois tempos da sua existência:

\section{a casa vazia e a casa habitada.}

Essas narrativas não prescindem das associações advindas do campo das imagens, o que para este trabalho se constitui em parte integrante e estrutural para a compreensão do que se pretende: compor uma outra camada possível de leitura da obra de Libeskind, através de um discurso visual, criando um retrato não verbal da casa, revelando a atmosfera das imagens a partir da sua própria vida e da constelação formada entre elas. Ainda para esta narrativa das imagens convoca-se um conjunto de figuras e metáforas ou um conjunto de imagens mentais e psíquicas que apresenta a problemática da visualidade contemporânea, mas numa relação entre o presente e o passado da imagem.

"A ideia clássica da janela é substituída pela interação permanente entre imagem e modelo, pela possibilidade de penetrar no interior da imagem, 
que se transforma em lugar, ao ver abandonada a bi dimensionalidade à qual estava condenada. Experiência em si, em potência, que possui outras possibilidades para além daquelas imediatamente visíveis"1

A casa do arquiteto, no bairro do Pacaembu, construída em 1961, na cidade de São Paulo é o tour de force, o objeto de recorte da sua produção que motiva a possibilidade de estabelecer a aproximação com o campo das artes plásticas e do design - desenhos, pinturas, ilustrações gráficas - permitindo afirmar que este arquiteto engendrou através da sua ação artística o desenvolvimento e a consolidação de uma linguagem, nos aspectos próprios do que isso se estabeleceu enquanto cultura moderna. Permite reconhecer em qual dimensão os aspectos regionais se inserem na obra de Libeskind - uma ambiência moderna brasileira que se complementa para além da arquitetura. A casa absorve como uma esponja aquilo que nela se fixa. E aí, surge uma brasilidade da contenção, no rigor do desenho, num lugar do modernismo que alia o funcional, a técnica, o apuro, o equilíbrio.

Também é possível afirmar que o "invasor moderno", como uma entida-

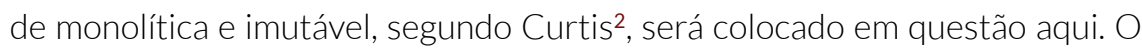
estágio alcançado pelas ideias nos países de influência condicionou, até certo grau, segundo o autor, "o ponto de partida nos países influenciados. Brasil, África do Sul, México e Japão, por exemplo, receberam uma arquitetura moderna quando ainda era novidade nas décadas de 1920 e 1930 e produziram suas próprias variantes no período entre guerras".

Desta forma, ainda segundo o autor, no período seguinte à Segunda Guerra Mundial estará caracterizado "por uma diversidade muito maior no movimento moderno nos seus centros de origem e por uma maior valorização do nativo, do variável e do regional. (...) As investigações pan-americanas de Wright, os ensaios de Le Corbusier sobre os temas vernaculares mediterrâneos, e até mesmo as ideias de Mies van der Rohe para casas com pátio tocaram pontos sensíveis em lugares inesperados onde os arquitetos lutavam com a necessidade de expressar aspirações modernas, mas ao mesmo tempo evocar algum tipo de continuidade regional ou nacional".

Assim colocado, o trabalho apresenta uma estrutura que a partir da leitura do objeto "casa" se abre para coleções de referências identificadas com

1 FABRIS, Annateresa. Redefinindo o Conceito de Imagem. Revista Brasileira de História. Vol.18, n.35. Escola de Comunicação e Artes - Universidade de São Paulo. São Paulo: 1998. p. 217-224

2 CURTIS, William J. R. (1982) Arquitetura Moderna desde 1900. 3. Ed. Porto Alegre: Bookman, 2008. p. 491 
a genealogia das ideias do arquiteto. Há, nesse sentido, uma impossibilidade

de controle, ou um limite de conteúdo, pois na órbita de tantas informações e imagens, procura-se construir um filtro, o que revela a tentativa de um encadeamento cauteloso, mas também muito pessoal dessa realidade.

Ainda sobre a ideia de um limite de conteúdo, há um limite de linguagem, e nesse caso, amplia-se a leitura para "tudo aquilo que é Arquitetura" 3 , ou na extensão da própria esfera humana e do sentido da afirmação do edifício construído.

Procura-se então circunscrever um ambiente cultural que redireciona a forma de identificar nos projetos o seu modo de operar, não mais agora orientado por uma leitura que se apoia nos registros tradicionais de apreensão a partir da representação gráfica da arquitetura, ou, dito de outra forma - a partir do desenho de arquitetura - mas na organização aberta de uma constelação que também pretende esboçar o perfil intelectual predominante de uma época, mais precisamente, das décadas de 1950 e de 1960, em São Paulo.

Assim, a busca em recolher imagens e referências externas traçam um percurso bastante distinto daquele proposto no mestrado, onde o método de leitura dos projetos era o próprio desenho per si e a sua análise geométrica, formal e programática aplicada aos projetos.

Coloca-se nesse procedimento um dilema, o paradoxo entre as imagens, como pensamento, e este, imaterial, em contraposição à matéria, que "personifica" as imagens, e, portanto, significam. Entre um e outro há o retrato verbal da casa, que estabelece relações entre o que se pensa e o que se vê, que tem por missão estabelecer um discurso lógico, expresso em ideias concatenadas.

A tese se conforma a partir da ideia de que a relação entre arquitetura (definida como espaço concebido e construído) e ambiente vivido, ou lugar (preenchido pelas coisas) definem a própria existência da casa e amparam a compreensão do significado da arquitetura.

Tem-se de um lado a imprevisibilidade da vida e a biografia da casa e das coisas em conjunto com o seu arquiteto-habitante e por outro lado, o gesto original, a casa vazia revisitada em outro tempo. Duas maneiras de olhar a casa que percorrem um arco temporal que descreve a dinâmica dos significados, o percurso dos sentidos das coisas, da arquitetura e da vida, numa estratégia para narrar a experiência sensorial da visita, que instrui através da descrição como forma de olhar e contar sobre a casa hoje.

3 URSPRUNG, Philip; LOPES, Diogo Seixas; BANDEIRA, Pedro. Eduardo Souto de Moura: Atlas de Parede Imagens de Método. Porto: Dafne Editora, 2011. p. 122 
Aqui também habita um pretexto para falar de algo que transcende a visita e que amplia as relações entre biografia e arquitetura, revelando o que a casa é, na medida em que o universo de referências se estabelece como costuras para compreender a obra também composta pelas coisas negligenciadas, elementos através dos quais o caráter dessa arquitetura se manifesta.

Outrossim, as imagens afetivas reúnem o acervo remontado, que se presta a revelar o que essa arquitetura deseja ser e sobre este arquivo de coisas não paira a exatidão do termo catalogação, num sentido mais rigoroso do termo.

Este conjunto reflete vários processos associados ao projeto de arquitetura e revela o Libeskind arquiteto, desenhista, ilustrador, artista. Aí, ele aparece como um mediador de imagens, entre passado e futuro que através do indício visual culmina na possibilidade da existência do projeto e da sua própria história. $^{4}$

Esta mediação será posta no trabalho pela observação da autora que legitimará um certo relativismo entre o projeto de arquitetura e a obra acabada, entre a ideia da edificação e a sua experiência vivida, ou entre concepção, vazio, imagem e materialização; e que, de forma ampliada, revela o domínio absoluto dos meios quanto à capacidade de Libeskind em conferir uma profundida expressão a uma visão de mundo idealista. Assim como colocado por Curtis ${ }^{5}$, sobre a obra de Wright, guardadas as devidas proporções, pode-se afirmar que, analogamente, em Libeskind, também parece plausível dizer que "As soluções incorporadas a suas obras parecem resolver questões de relevância muito maior do que suas circunstâncias particulares. Elas (sic) cristalizam as preocupações de um período e influenciam outros distantes no espaço e no tempo".6

Abrem-se a partir deste ponto, duas janelas fundamentais de articulação no âmbito da produção de Libeskind, entre pintura e arquitetura e entre design e arquitetura reveladas através das presenças de Alberto da Veiga Guignard na primeira e Joaquim Albuquerque Tenreiro, na segunda.

As analogias com estes interlocutores que resultam no trabalho estão numa relação livre e resolvem ou sintetizam a própria expressão da arquitetura de Libeskind numa organização de narrativas em fragmentos, colisão de

"Pensar em imagens de forma associativa, selvagem, livre, ordenada e sistemática, em imagens arquitetônicas, espaciais, coloridas e sensuais - isto é a minha definição preferida do ato de projetar". In: ZUMTHOR, Peter. Pensar a arquitetura. Barcelona: Editorial Gustavo Gili, 2009. p. 21 
diferentes temporalidades, em busca de uma dimensão poética e subjetiva no

contexto de uma modernidade que procurou uma ambiência brasileira afinada com o desenho moderno de tradição mais rigorosa e funcionalista.

O esvaziamento completo da habitação com a morte do arquiteto é a condição que mais aproxima a casa do espaço idealizado, do espaço projetado, pois a morte é, neste caso, também o começo.

No ano de 2016, a casa vazia é revisitada como ponto de partida ou de chegada que retorna para o tempo da casa vivida e habitada, durante os anos de 1961 (conclusão da obra) e 2014 (morte do arquiteto David Libeskind).

Em sua condição de nudez escancarada a casa permite ser percebida como a materialização do espaço imaginado, abstração das ideias do projeto concepção - espaço sem vida.

A casa desabitada e sua coleção de objetos ausentes não conta mais a história da vida, ela narra a memória do projeto, da escala da assepsia, da linguagem dos elementos construtivo-espaciais sem distrações - a expressão pura da arquitetura. A casa que se esvaziou do seu habitante-artista. A casa é devolvida para o plano conceptivo, anterior às marcas e aos hábitos que lhe foram adicionados com a vivência.

A construção do trabalho se apoia nas ideias de simultaneidade e ambivalência, nas frestas transparentes que se revelam com as sobreposições das texturas impressas pelo tempo.

Este ensaio sobre a ausência ou sobre a desaparição dos seus habitantes e dos seus objetos permite discutir o espaço enquanto sintaxe moderna - ideário das figurações dos elementos compositivos e construtivos. Assim, de que maneira este espaço está composto, como se relaciona com o sitio, o que está priorizado no jogo das hierarquias das articulações internas, mas, sobretudo, como que este conjunto permite revelar os canais de diálogo abertos por Libeskind com suas referências intelectuais expressas de projeto, Frank Lloyd Wright e Richard Neutra.

Fato este que permite afirmar que há uma condição material primordial que se apresenta então, para além da arquitetura resolvida enquanto articulação dos planos horizontais e verticais inerentes à dança geométrica da casa, mas num apelo visual e táctil que a conecta com o caráter perdido na arquitetura no âmbito de algumas experiências modernas.

Este caráter apontado pela expressão de sua arquitetura recupera o sentido simbólico do espaço, que se organiza através do diálogo sensível entre forma, ambiente, materiais e num sentido mais ampliado, que se manifesta na ideia do próprio campo cultural. Uma construção que ganhou lugar nas expe- 
riências de um grupo de arquitetos paulistas, não obstante, que também estavam envolvidos com a concepção dos móveis e das obras de arte que figuraram enquanto qualidades complexas da arquitetura como expressão de uma cultura brasileira ainda em busca de um lugar genuíno nas décadas de 1950 e 1960.

Wright, em "In the Nature of Materials: a Philsophy", texto de 1943, revela o interesse nos materiais, a partir das suas características específicas e naturais e no seu emprego sob circunstâncias particulares: pedra, tijolo, vidro, concreto, metal. Os pensamentos e ensinamentos de Wright representaram um antídoto poderoso à cultura dispersa e depredada pela guerra na Europa, segundo Zevi. ${ }^{8}$

É possível construir essa ponte entre as ideias de Wright e de Libeskind, uma vez que a casa é um contentor de experiências, advindas da vivência do espaço interior, de uma integridade em busca do significado da forma. Um novo ideal para a arquitetura seria, então, um ideal adequado para a cultura geral, num sentido de plenitude e de busca de sentidos coerentes com o contexto vivido.

E apesar da riqueza expressiva, que, sob algum aspecto, poderia remeter à ideia do ornamento, é importante esclarecer que a procura é pela síntese, por uma poesia inerente, que, segundo Wright, "possa comunicar a mesma simplicidade orgânica da $5^{\text {a }}$ Sinfonia de Beethoven, aquela revolução espantosa no tumulto e no esplendor sonoro, construído com apenas quatro notas que qualquer criança seria capaz de dedilhar no piano com apenas um dedo. A suprema imaginação que, provavelmente, poderia remeter ao edifício mais nobre jamais projetado no mundo". 9

Essa morte-vida da casa, no âmbito das narrativas pretendidas para este trabalho, revela este arquiteto-artista e seu trabalho de "genesis animada" dessa arquitetura, onde é possível imaginar em cada janela uma pessoa recostada, para cada porta, uma pessoa passando, para cada escada uma pessoa subindo e descendo, para cada terraço, alguém descansando, para cada sala, pessoas socializando. Ainda que, essa arquitetura também possa revelar a si mesma, não habitada e isolada dentro das suas próprias leis de existência.

"Uma casa não é uma casa se ela não for quente no inverno, fresca no verão, serena em cada estação, recebendo a família em espaços harmo-

7 From Frank Lloyd Wright, An Autobiography (New York: Duel, Sloan and Pearce, 1943), p. 33749. Apud: OCKMAN, Joan (1993). Architecture Culture 1943 1968: A Documentary Anthology. 2nd. Ed. New York: Columbia Books of Architecture, Rizzoli, 1996. p. 31-41

8 ZEVI, Bruno (1951). Saber ver arquitetura. 4a. ed. São Paulo: Editora Martins Fontes, 1994. p. 51

9 WRIGHT, op. ct., 1943. p. 31-41 
niosos. A casa não é uma casa se ela não contém um canto para ler poe-

sia, uma alcova, uma banheira, uma cozinha. Essa é a casa do homem. E o homem não é um homem se ele não possuir essa casa. Essa casa existe? Ela alguma vez existiu?"10

Construir e habitar a casa revela dois papéis assumidos por Libeskind considerando que esta foi a única casa que ele projetou para si e para sua família viverem; assim, o arquiteto converteu-se em idealizador e ao mesmo tempo habitante do edifício por ele projetado. E habitar, segundo Heidegger em seu texto seminal "Construir, Habitar, Pensar"11 propõe que um edifício sempre tenha como seu objetivo final, ser habitado, ou, alguns edifícios, mesmo que não programados para a habitação, estejam sob o domínio do habitar. Este domínio ultrapassa a noção de que um edifício só é habitado respeitando o programa de necessidades de uma casa. Nesse sentido, habitar extrapola um teto abrigado; habitar e construir se relacionam como fim e sentido. Construir não é simplesmente um meio para habitar - construir já é, em si, habitar. É preencher de vida, completar a arquitetura e dar sentido ao projeto com a matéria vida.

A casa do arquiteto é a casa manifesto. Fato que reúne, mesmo que esta casa esteja submetida a questões de outras ordens (que por vezes não afetam os projetos para clientes) o universo das possibilidades que convoca história, memória, afeto, desejos, sonhos, política. A casa se converte, na prática, em ação das escolhas estéticas preteridas, materialização da vida até o tempo presente de sua existência, onde "todo o passado vem habitar na nova casa,(...) memória e imaginação permanecem associadas, cada uma trabalhando para o seu aprofundamento mútuo".12

A presença de Libeskind na casa após a sua morte também possibilita refletir sobre a condição de como que a contiguidade entre vida a morte foi se destruindo com o tempo provocando a separação entre o mundo material e o mundo imaterial. Esta ideia, colocada por Eduardo Sacriste ${ }^{13}$, revela a relação entre o habitante e a sua casa que se rompe com a morte: "a casa também morre"14.

Tradução livre de "A house is no house if it is not warm in winter, cool in summer, serene in every season, receiving the family in harmonious spaces. A house is no house if it does not contain a corner for reading poetry, an alcove, a bathtub, a kitchen. This is the house of a man. And a man is no man if he does not possess such a house. Does this house exist? Did it ever exist?". E. Nathan Rogers publicado in "Programma: Domus, la casa dell'uomo" in Domus, January 1946. Apud OCKMAN. p. 79

HEIDEGGER, Martin. Poetry, Language, Thought. Hofstadter (org.). Nova York: Harper \& Row, 1971. p. 41

12 BACHELARD, Gaston. A Poética do Espaço. São Paulo: Martins Fontes, 1993. p. 232

SACRISTE, Eduardo. Queés la casa. Colección Esquemas, Buenos Aires: Editorial Columba, 1968.

"As habitações dos mortos, já separadas das dos vivos, mesmo que ainda semelhantes às deles 
Dessa forma, a casa do Homem, é a sua gênese. Libeskind, que concebe o projeto da casa, habita o espaço e recolhe neste espaço todos os elementos afetivos, históricos e simbólicos que conferem a definição de um caráter diferente para a casa, que atribui a distinção entre casa e habitação.

Assim a casa também se transforma, sobrevive materializando as marcas de uma vida passada. E nessa sobrevida permanece, mesmo após a morte do seu criador, como obra da vida, inacabada, continua, suspensa e precária, como o tempo da vida impresso nela mesma.

A casa, a partir daí, obedece apenas à sua própria lógica impermanente: sua ordem interna de existência.

em sua estrutura aparente, apresentam uma distância intransponível: os povos malgaxes (de Madagascar) chamavam as tumbas de "a casa fria", porque nelas jamais se acenderia o fogo. E para os nômades tuaregues (povo nômade africano) as casas são as tumbas dos vivos.

Na Nova Caledônia (arquipélago situado na Oceania) as casas são construídas de tal modo que quando morre o seu proprietário, a mesma se converte em sua tumba. A porta é selada e a este sarcófago particular denomina-se "maciri", quer dizer, "lugar dos mortos".

Um ritual bastante difundido em algumas culturas é o abandono da casa cujo o amo morreu. E como a casa serve para uma vida, a construção se "alivia" e se converte em "morada efêmera."

No Cairo, assim como em quase todas as cidades árabes, a maioria dos palácios são feitos de material leve e se encontram em ruinas. São muito pouco reparados e no idioma nativo os termos reparar e construir praticamente não se distinguem. Um proverbio árabe alude esotericamente a essa relação íntima das coisas concluídas: "Quando a casa está concluída, penetra a morte." 



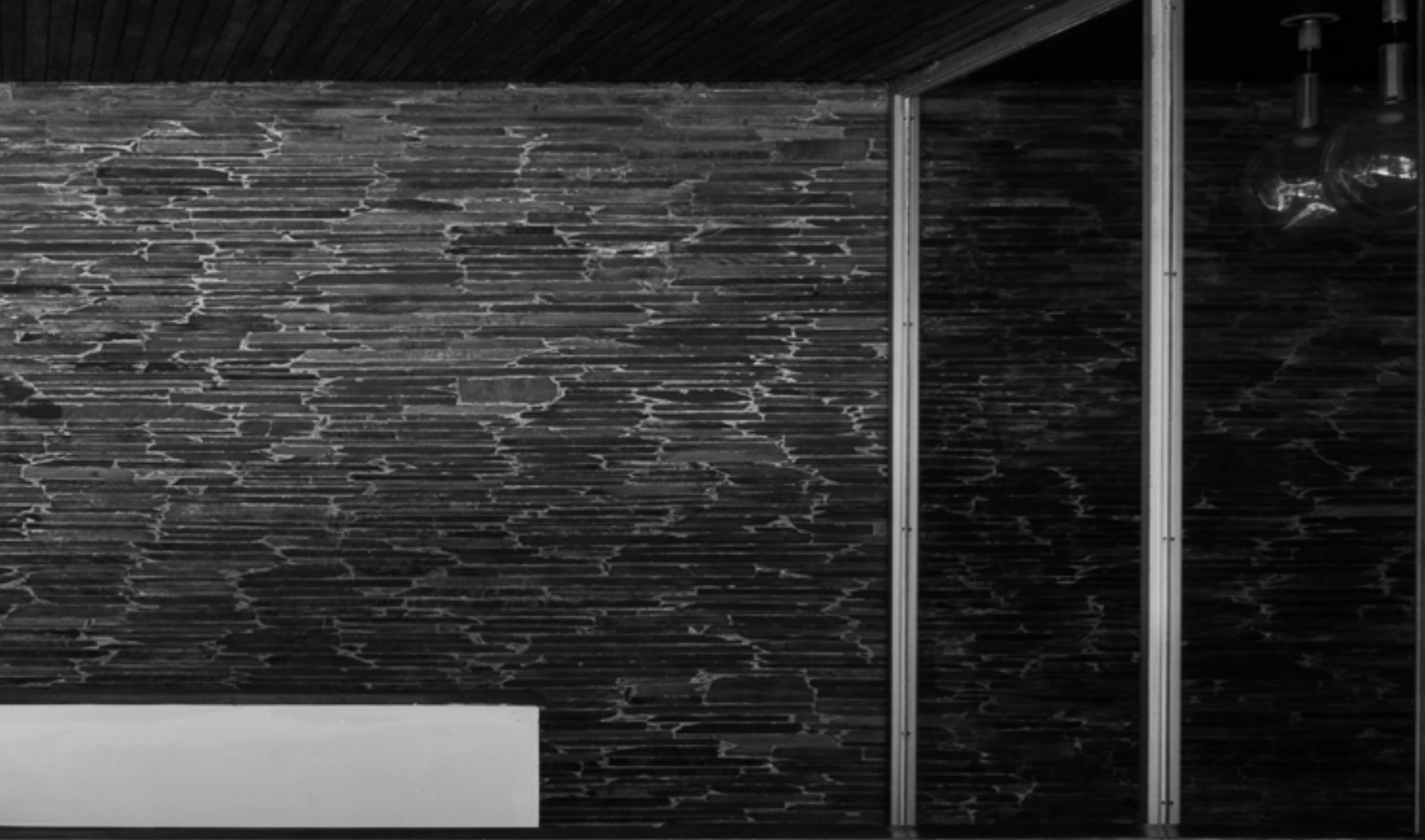
BIOGRAFIA DE UMA CASA 
"A arte é uma cultura cujos conceitos são expressos por imagens em

vez de palavras; e a imaginação não é uma fuga do pensamento, mas um pensamento tão rigoroso quanto o pensamento filosófico ou científico."

Giulio Carlo Argan

A biografia da casa de Libeskind não é narração escrita dos fatos particulares das várias fases da sua vida: descrição, história, lembranças, memórias, recordações e relatos.

É isso também, mas convoca, em face do desaparecimento, a história documental e as imagens - aquilo que existe para além do registro formal.

A biografia de Libeskind foi feita no mestrado, sujeita ao encadeamento de fatos no tempo - datas, lugares, pessoas, organizados para que o universo da sua produção fosse revelado. Não apenas isso, mas o material resultante da pesquisa colaborou para oferecer informações inéditas para a historiografia em construção da arquitetura moderna brasileira naquele momento.

A biografia da casa de Libeskind, objeto de estudo deste doutorado, sugere uma operação que insere a autora numa situação de experimentação inédita que entretece as narrativas oral e visual. É uma escritura para além da prosopopéia, porque não pretende dar vida a um ser inanimado, atribuindo-Ihe existência e sentimentos. É a extração da vivência de Libeskind nessa casa que encerra, contem, sintetiza e permite ser, ela mesma, um ato biográfico. Porque nela está contada a história, não exatamente ordenada e encadeada de forma temporal linear, mas cada elemento ou célula deste organismo revela o seu lugar de origem. Há uma inscrição arquitetônica, fruto dos apontamentos de diversas matizes que surgem na casa, subjugadas por aquilo que Libeskind entendia ser. A casa é a representação dele próprio e assim vai em progressão se autoconstruindo no emaranhado de elementos que a ela são associados, pois, "o passado, a partir daí, não será uma simples herança, mas uma construção."1

A construção da biografia de uma casa é a descrição de um arco temporal que ultrapassa o tempo de existência da casa, recolhendo ocorrências anteriores em um encadeamento narrativo com sobreposições e colagens de fatos e personagens contíguos ou conviventes. A casa exprime a sua própria história, narra sua biografia ou história de vida. Há um caráter cinematográfico nessa biografia, com um roteiro entre palavras e imagens que se completam, 
não como ilustração, mas como recurso para que as histórias dessa casa e do arquiteto se entrelacem.

Indica-se assim, com a tese, que essa é a única história possível a permanecer, percebida na força de uma experimentação sensorial e intelectual. Portanto, apenas a casa pode ser uma biografia autêntica, porque nela a vida se construiu e se consumiu, incorporando valores e aspectos simbólicos. Aquilo que a narrativa de fatos concretos jamais poderia evidenciar.

A biografia da casa de Libeskind também é o retrato dos vestígios de uma lembrança, reflexo do invisível amparado por toda a coleção de informações do seu acervo profissional e pessoal, o que possibilita apreender o caráter metafórico e essencial presentes no seu imaginário.

Nesse sentido, casa é um conjunto de biografias no devir do seu percurso. E independe do seu habitante físico quando pode contar, ela mesma, uma história, porque deixa de ser apenas um repositório de padrões, quer dizer, exemplares e modelos circunscritos no tempo e no espaço. Neste caso a História é uma potência, motor que impulsiona uma outra história, narrada pela casa. E o tempo, flexível, para que essa biografia possa desfrutar do ir e vir da memória.

Esta coleção de biografias contida na própria biografia está posta ao lado de todas as narrativas paralelas convocadas para assentar a operação acima referida, a hipótese de que os fatos concretos apenas amparam, mas não escrutinam, na realidade, a história.

Esquadrinhar esse conjunto composto por inúmeros personagens extrapola mais uma vez o objeto na sua concretude, convocando aquilo que displicentemente é considerado periférico ou de menor importância, porque para construir a biografia de uma casa tudo importa. Na sua existência habitada ou vazia, o que está impresso, registrado, denotado, marcado, fincado habita em consonância com o que está em suspensão, sumindo, derretendo, desmanchando e desaparecendo. Mundos em oposição que só podem se encontrar através de outros recursos não limitados pelo registro escrito.

A biografia da casa permite descobrir o que existe para além da pedra e da forma, pesquisa metonímica sobre Libeskind e sua obra, esboço de uma ontologia de um projeto de arquitetura. Nessa reflexão se torna evidente que não há um lugar demarcado onde começa a Arquitetura e termina a Pintura, ou onde começa a Arte e termina o Desenho Gráfico.

A condição fundamental que faz a casa concentrar em si a possibilidade biográfica é o habitar do arquiteto. Qualquer outra obra de LIbeskind teria condições de exemplificar os seus princípios projetuais, revelar suas preferên- 
cias no trato das superfícies, das resoluções estruturais, das formas espaciais,

mas só ali onde os fatos da vida e da casa formaram um amálgama com as escolhas arquitetônicas seria possível desvelar um valor a ser ultrapassado, perseguido neste trabalho. 


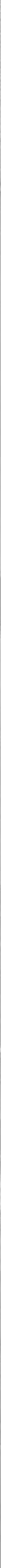



PRIMEIRO ATO: UM PROJETO DE ARQUITETURA 


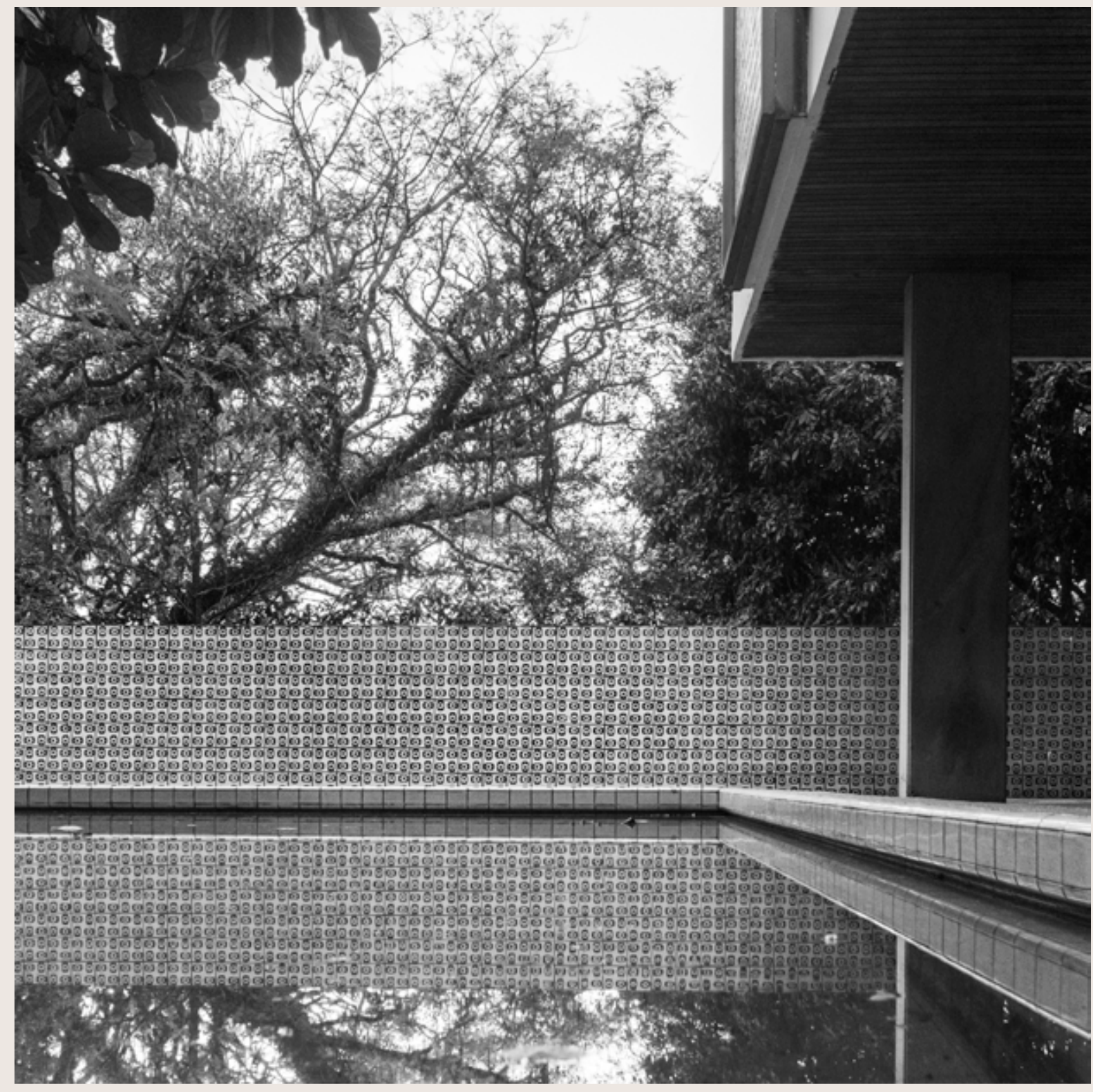




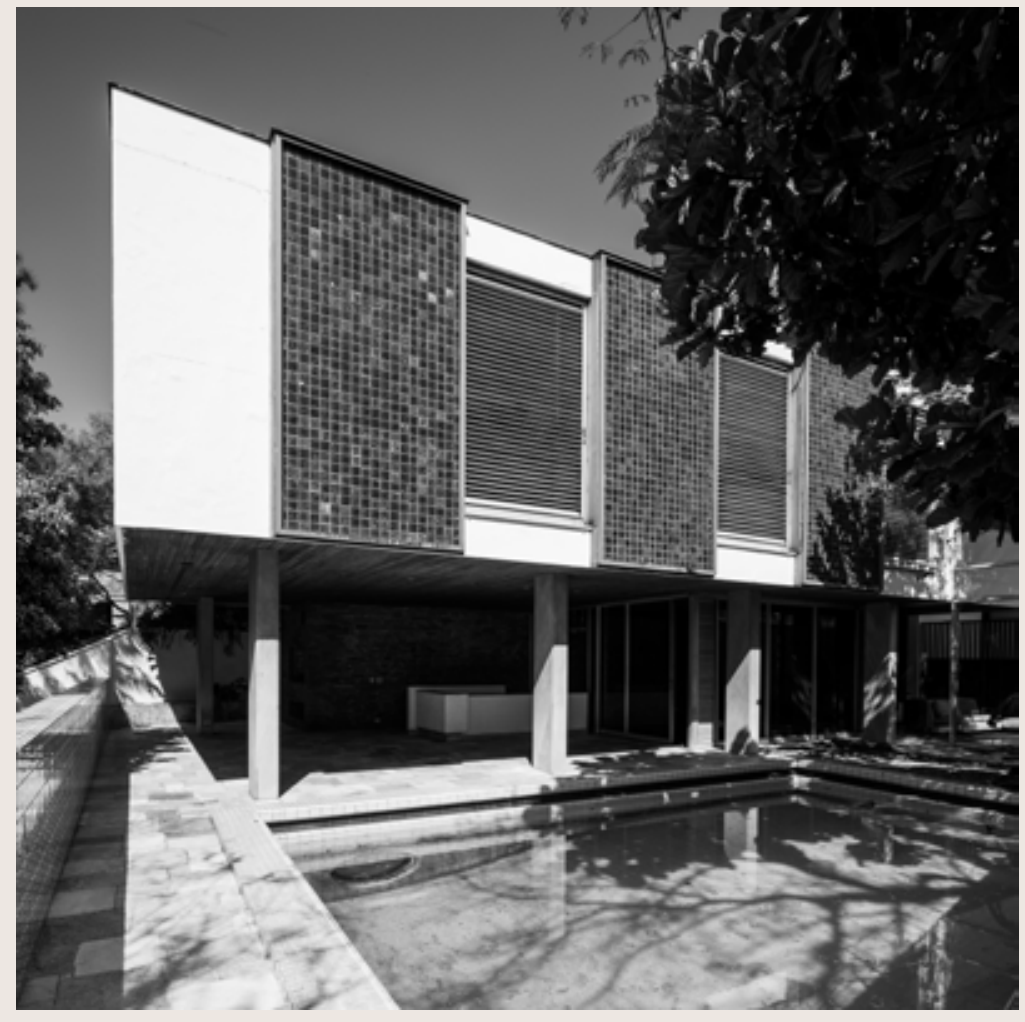



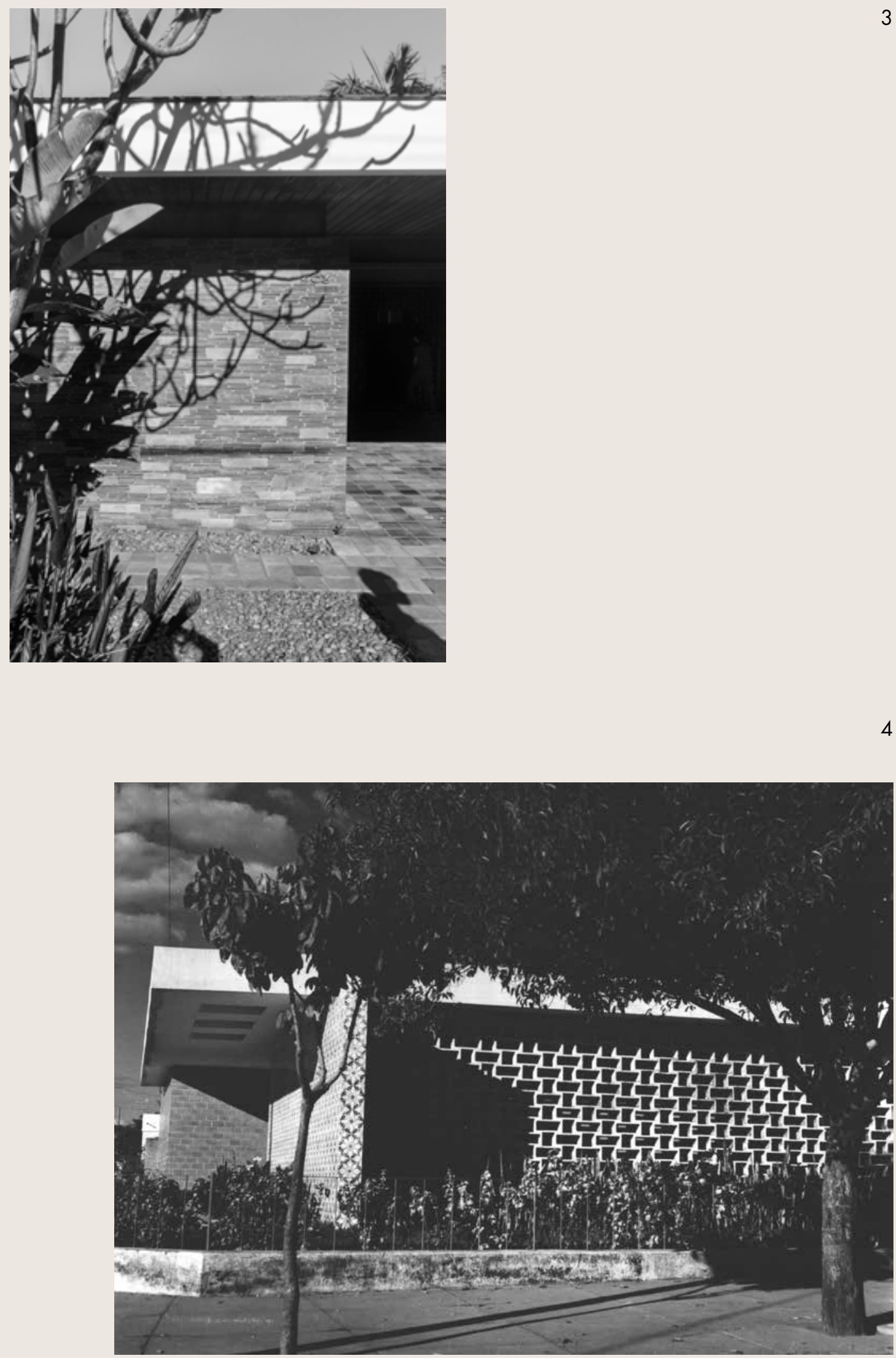


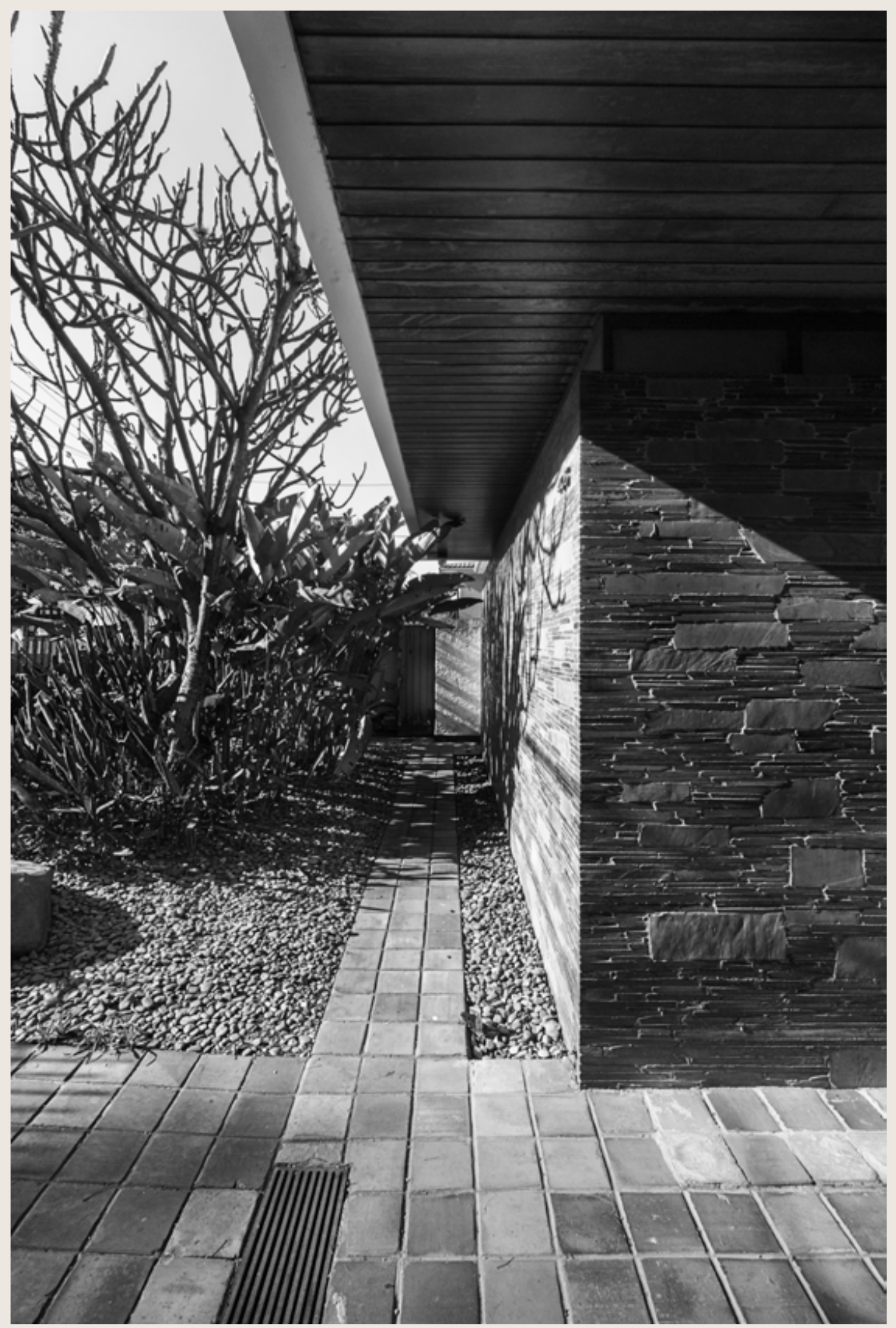




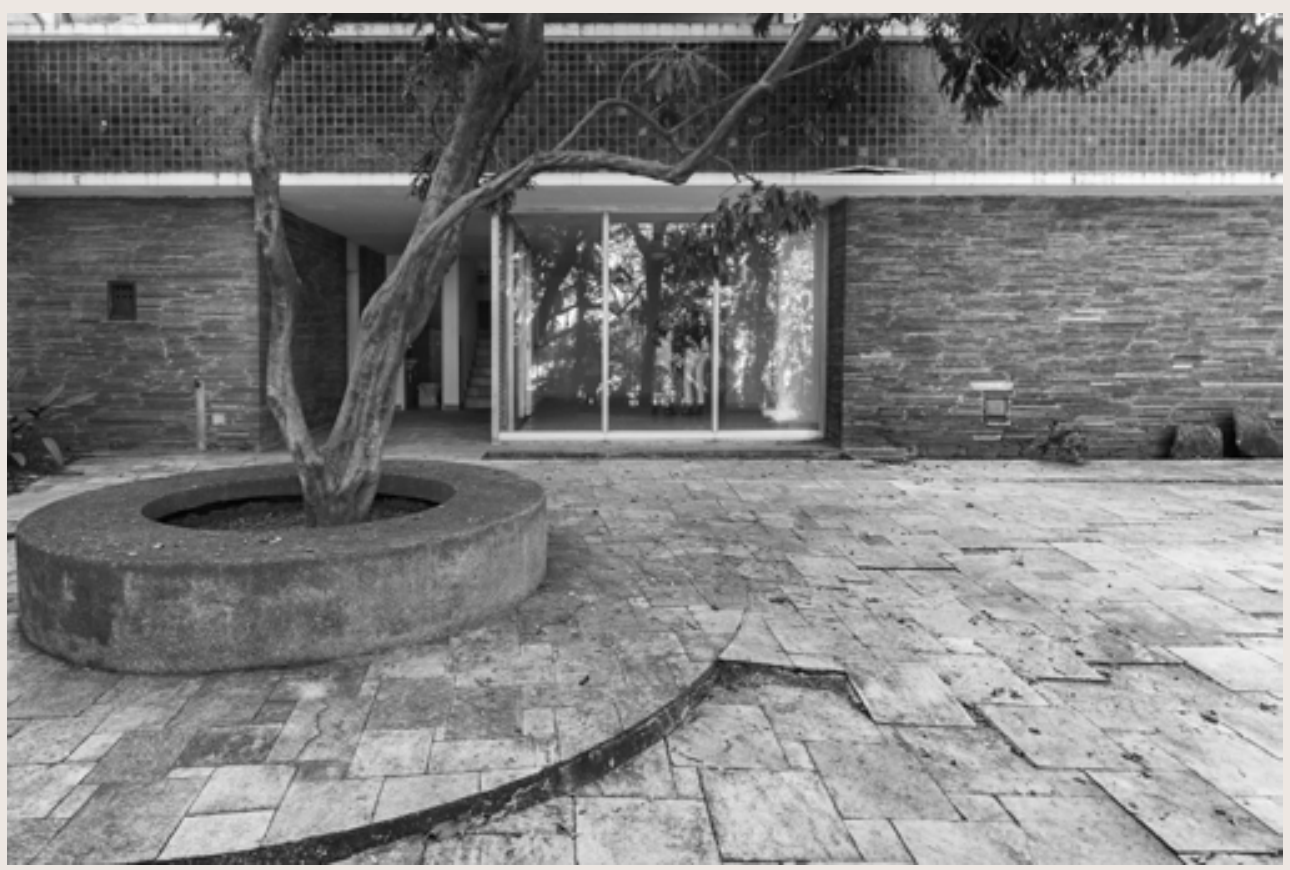



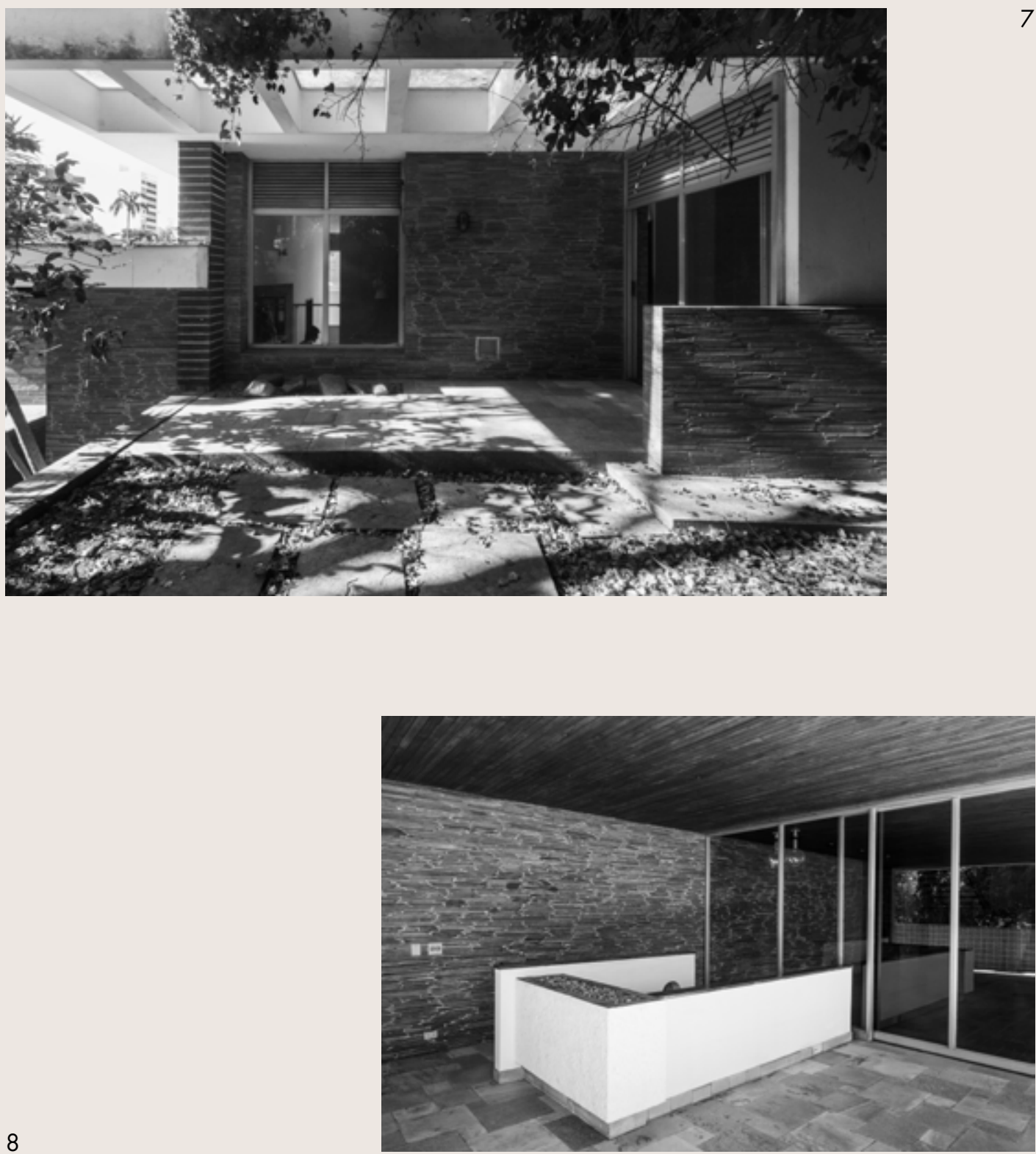

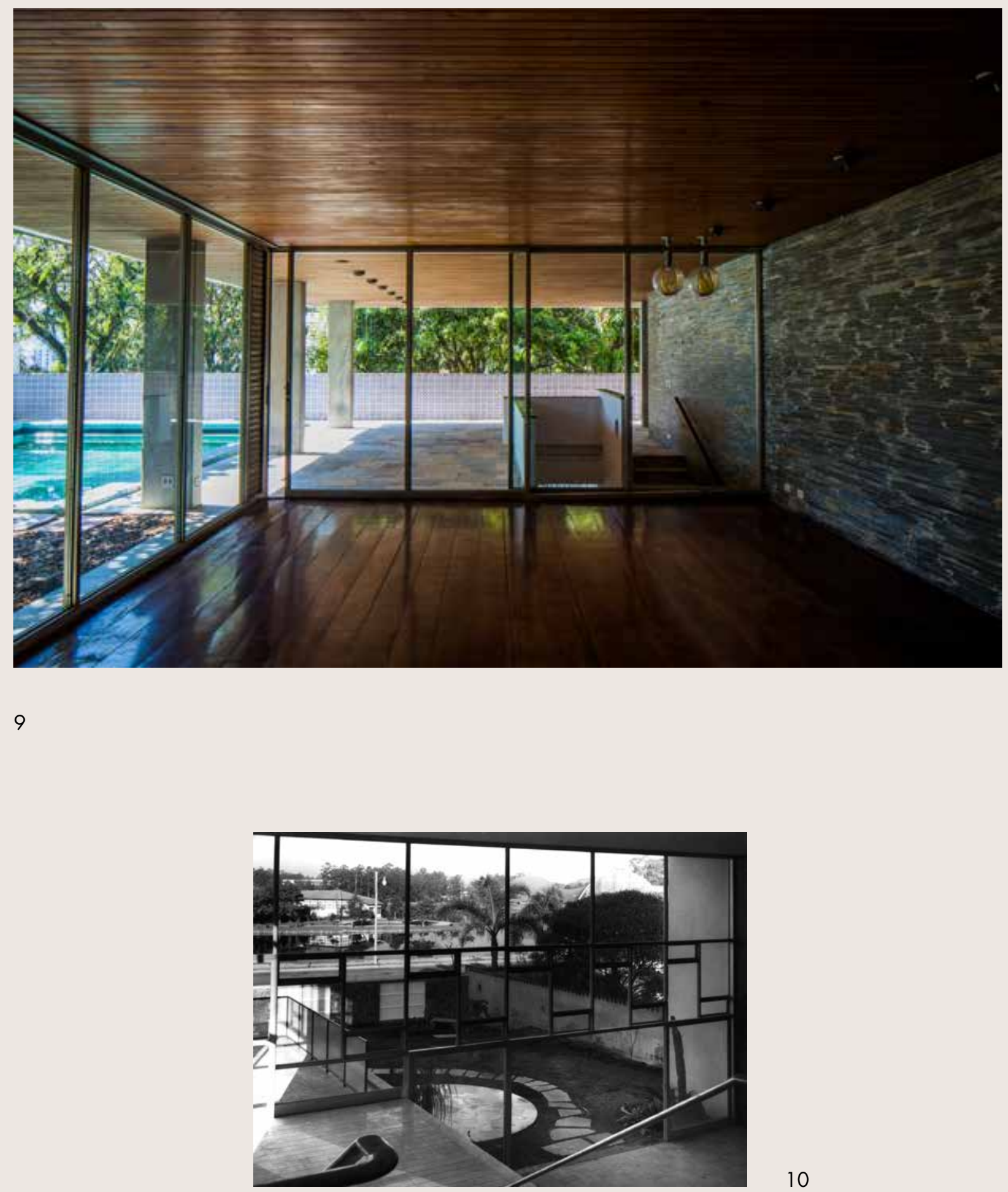

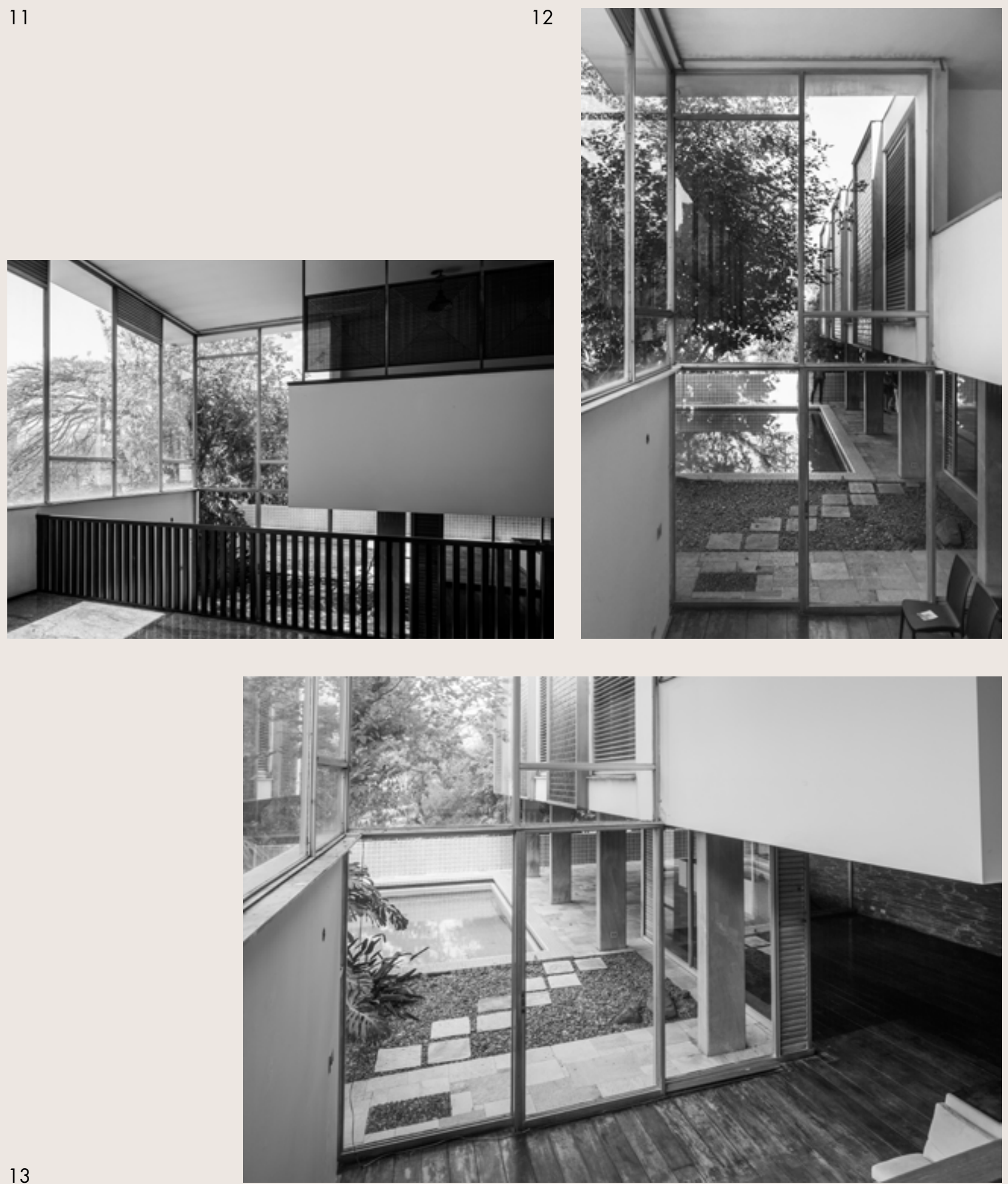


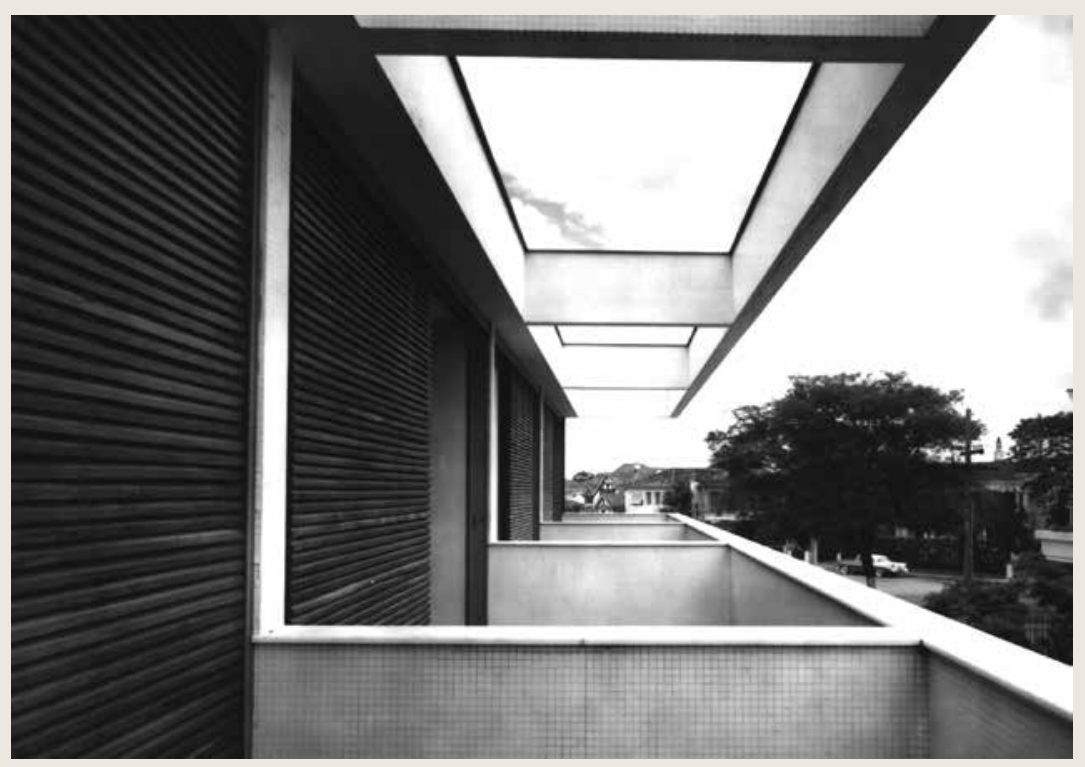

14
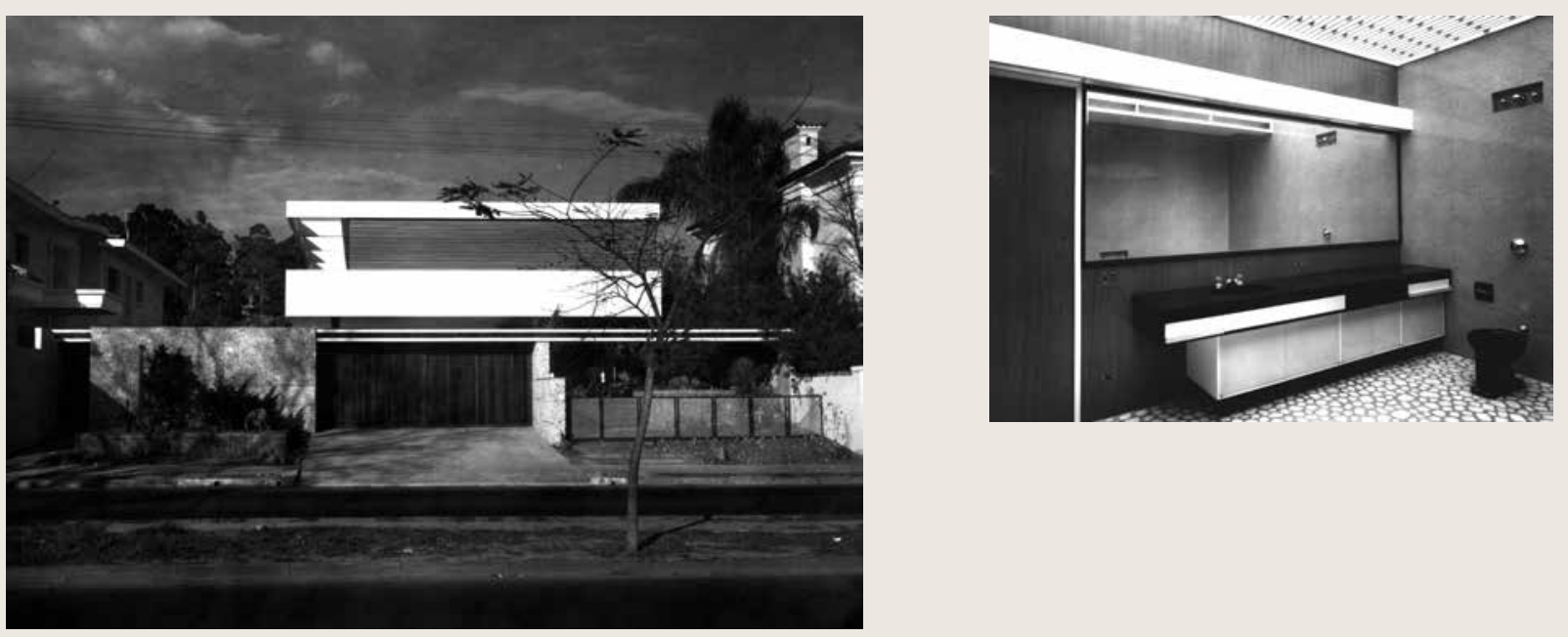

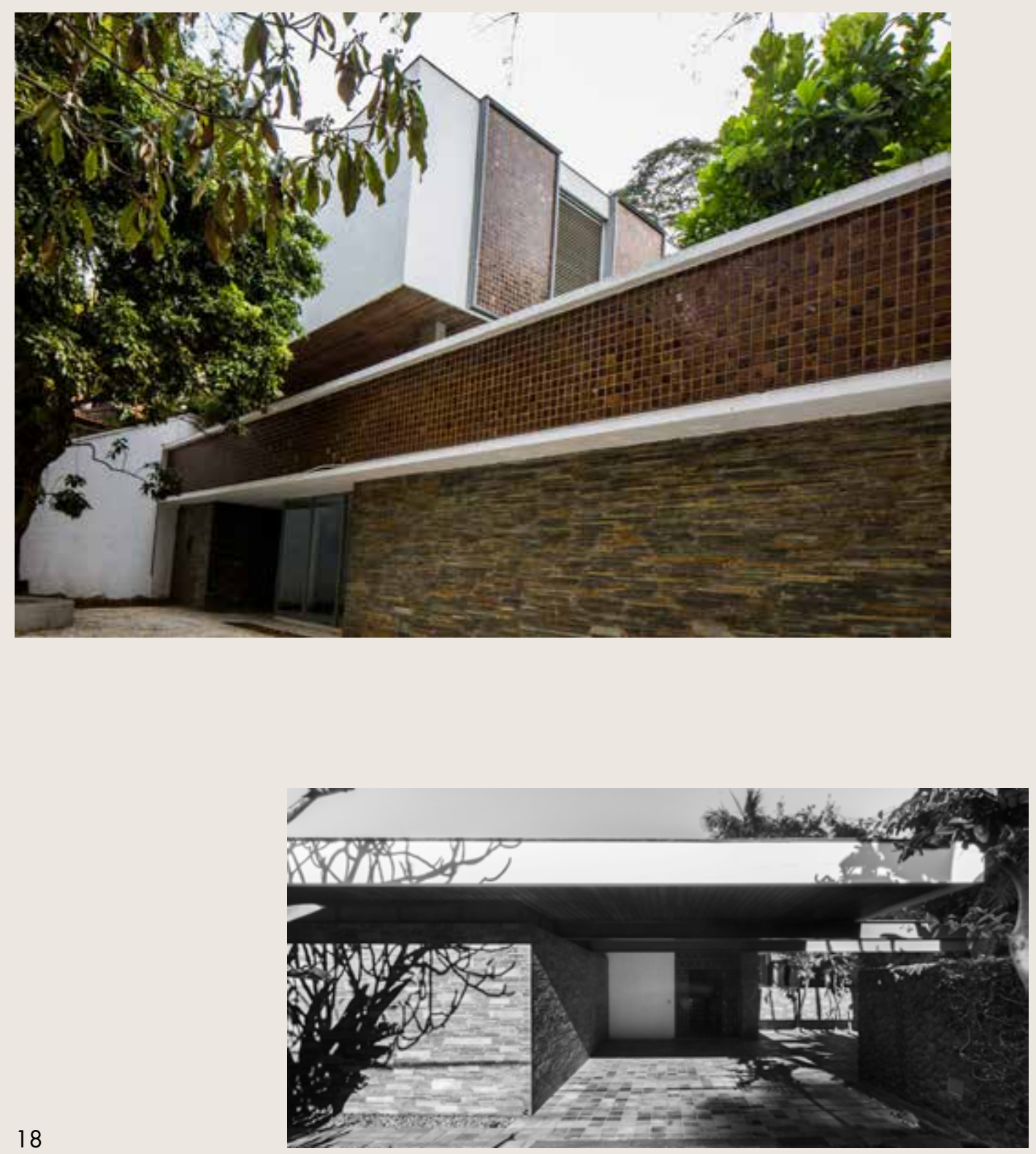


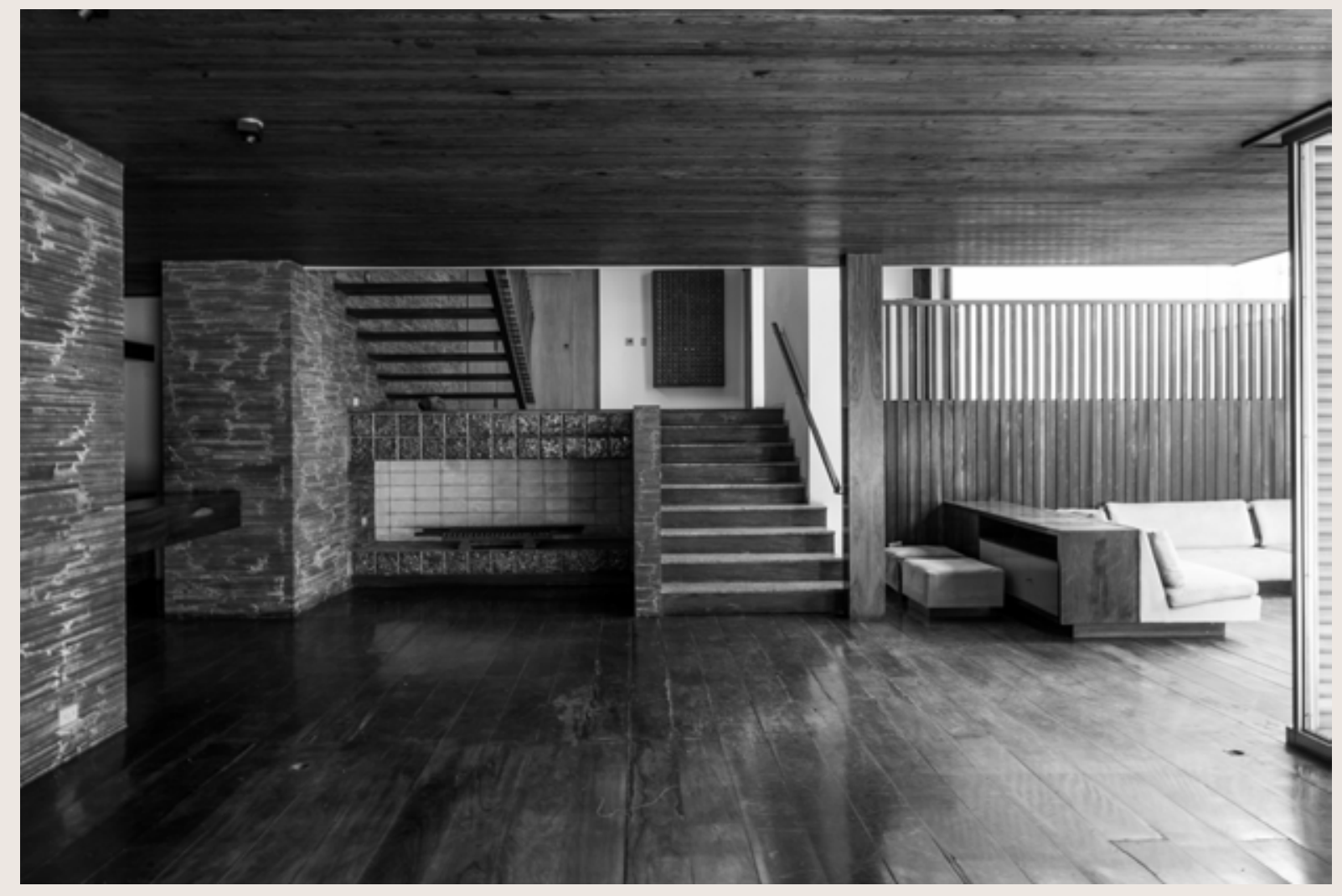



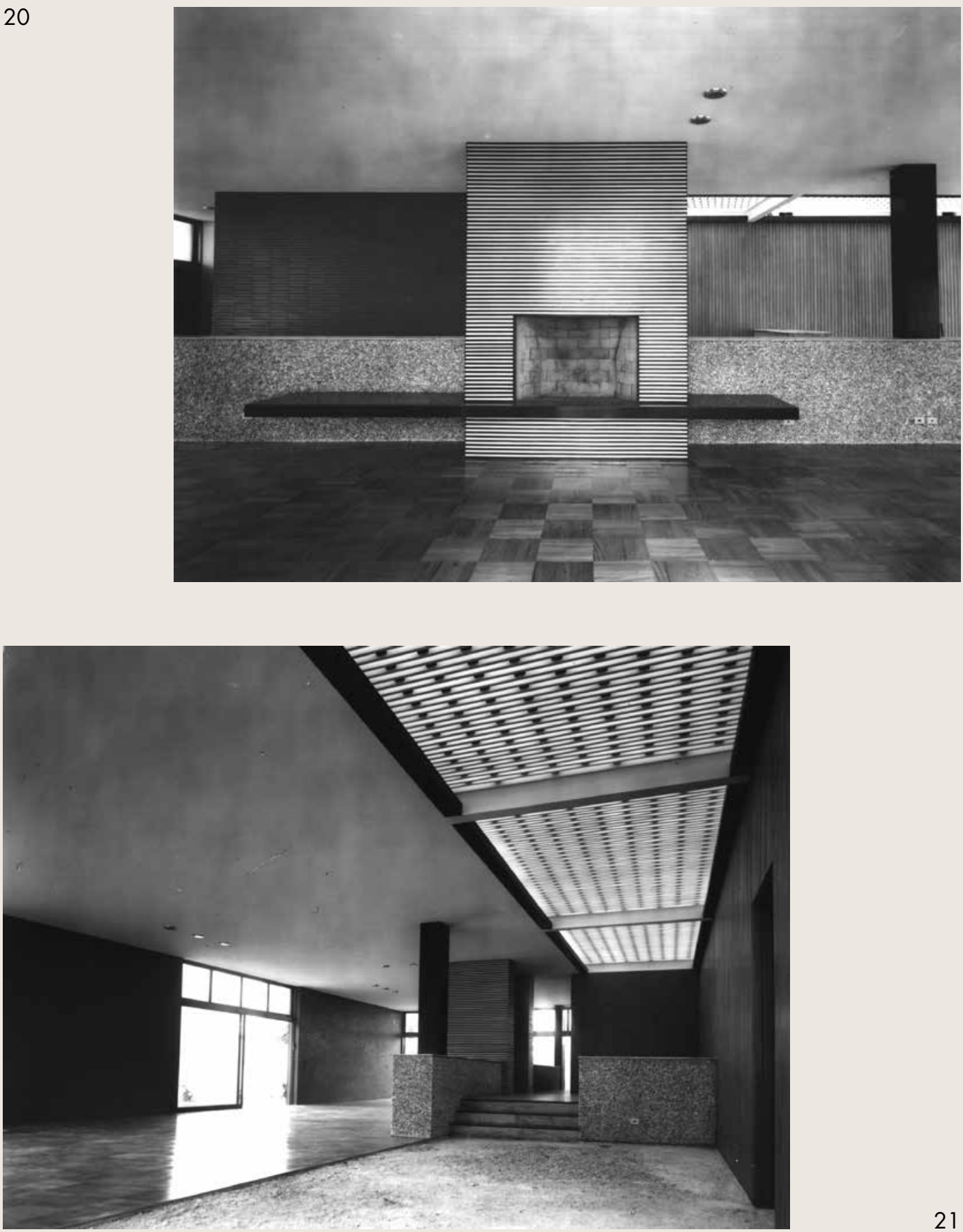

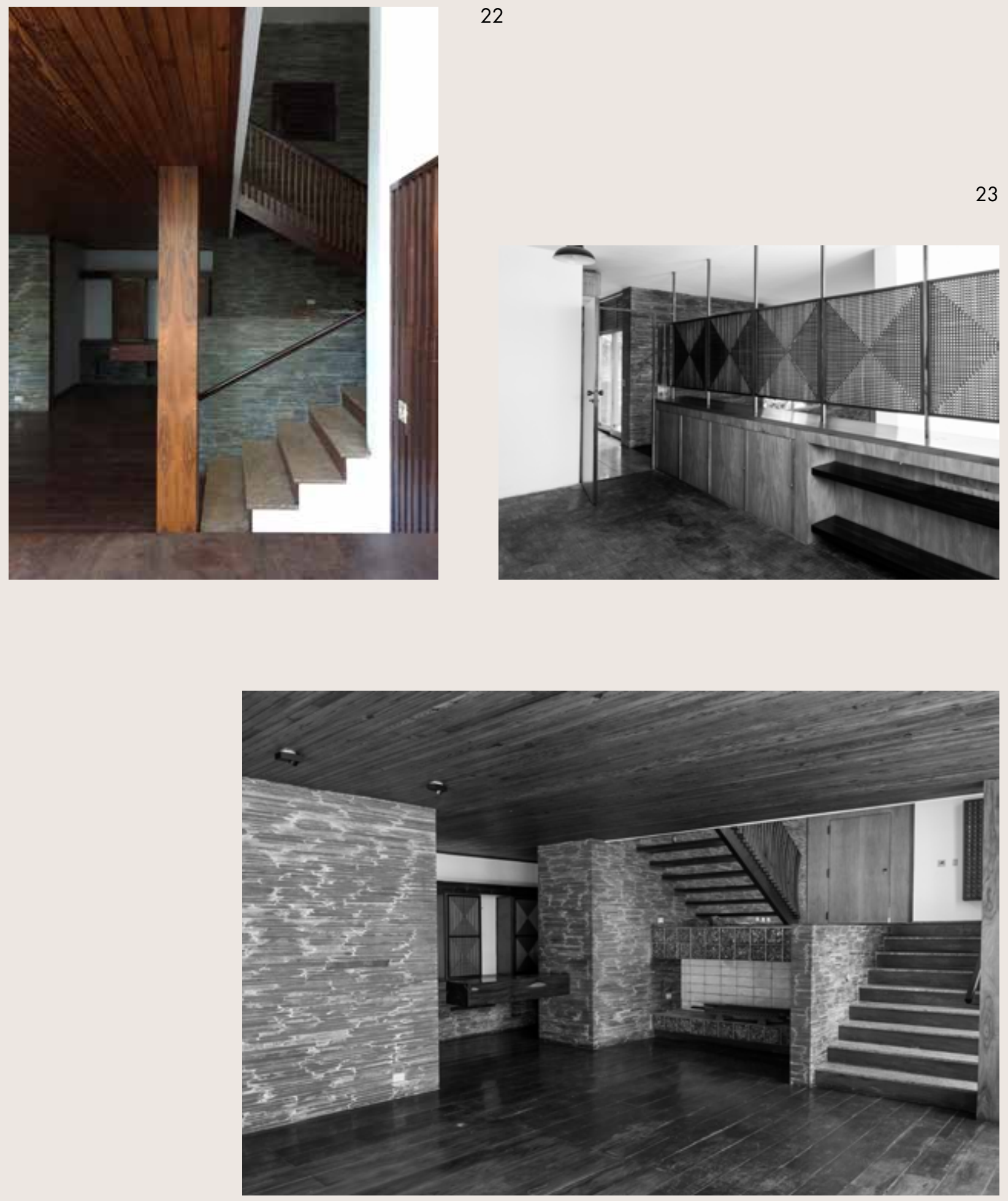


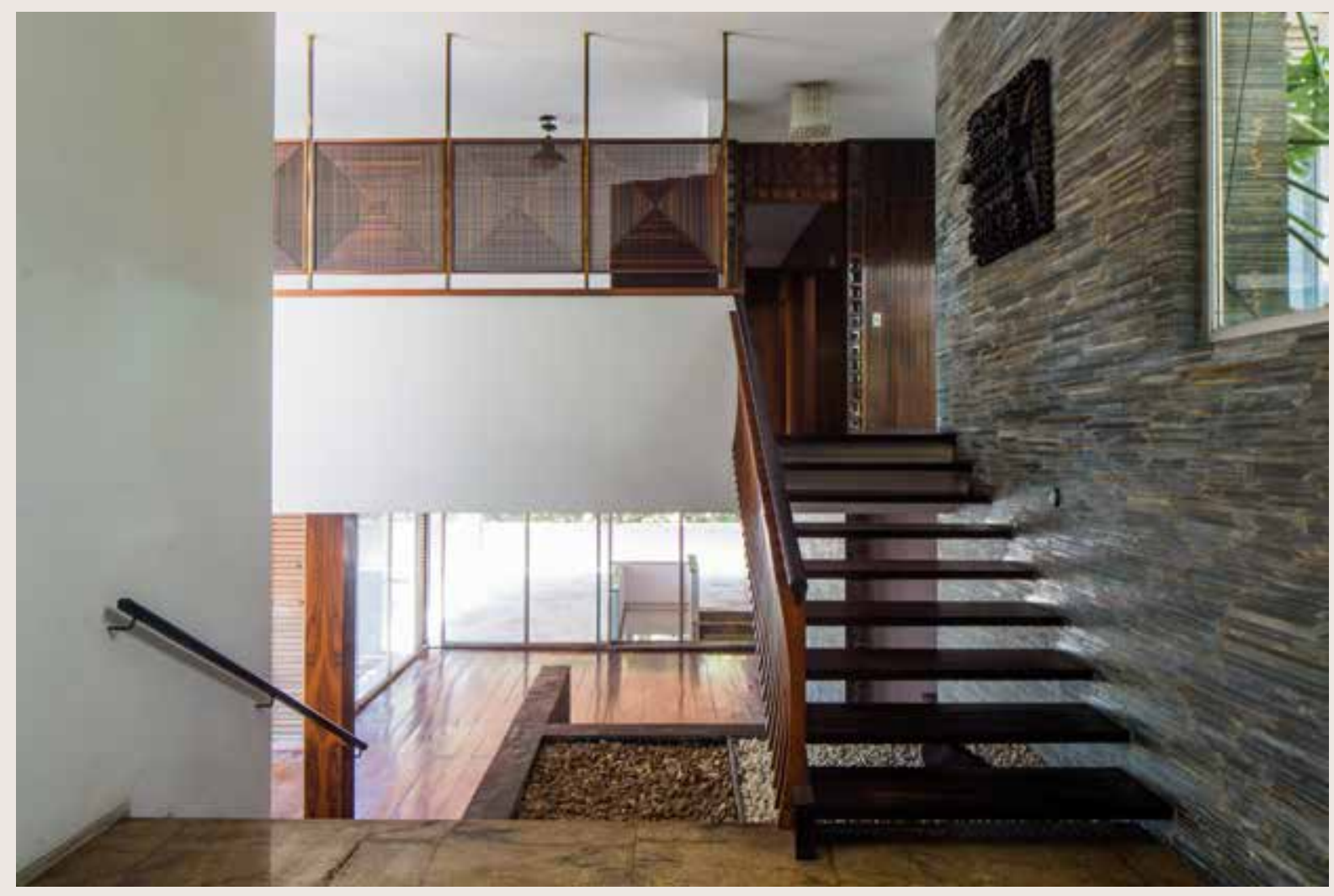



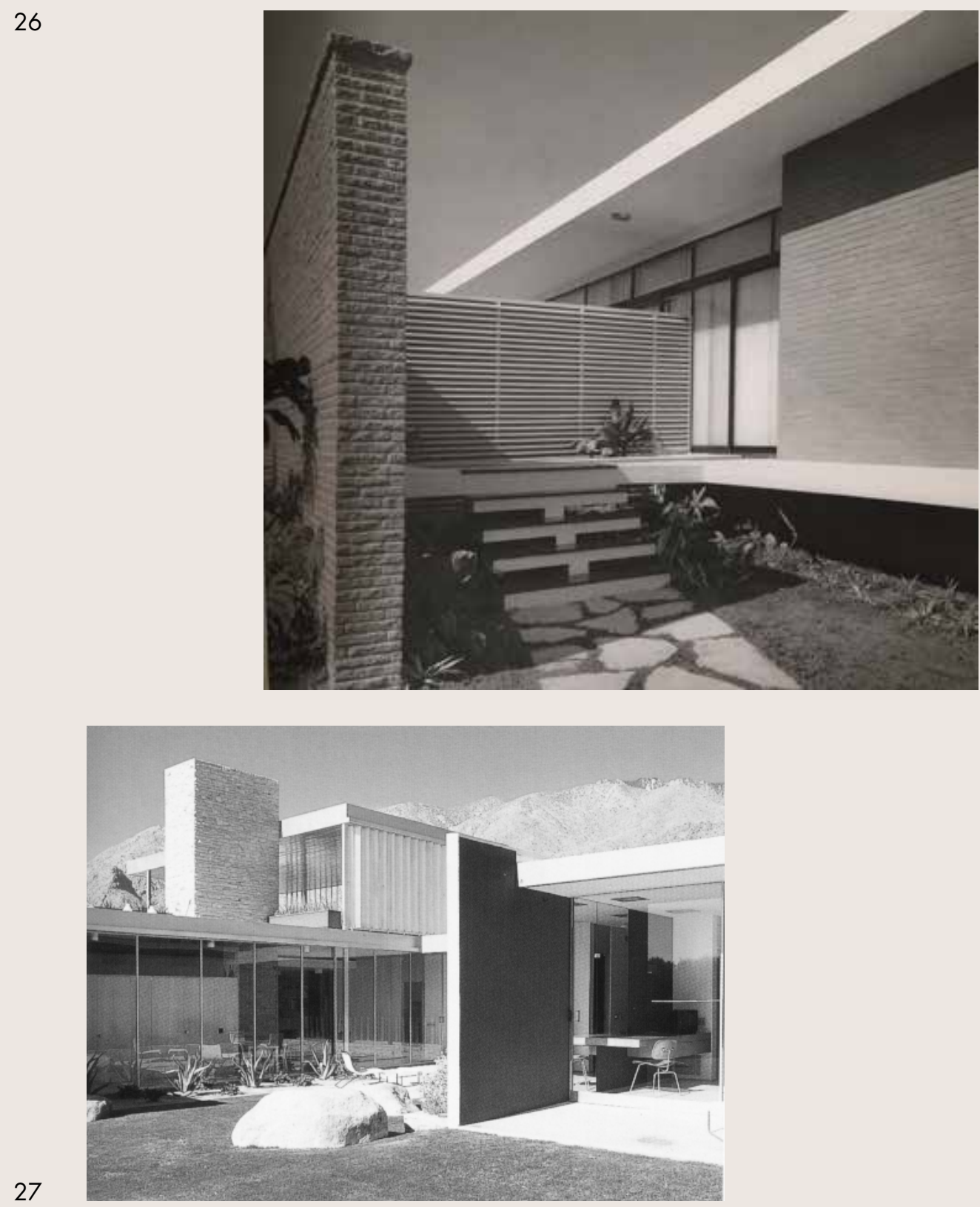

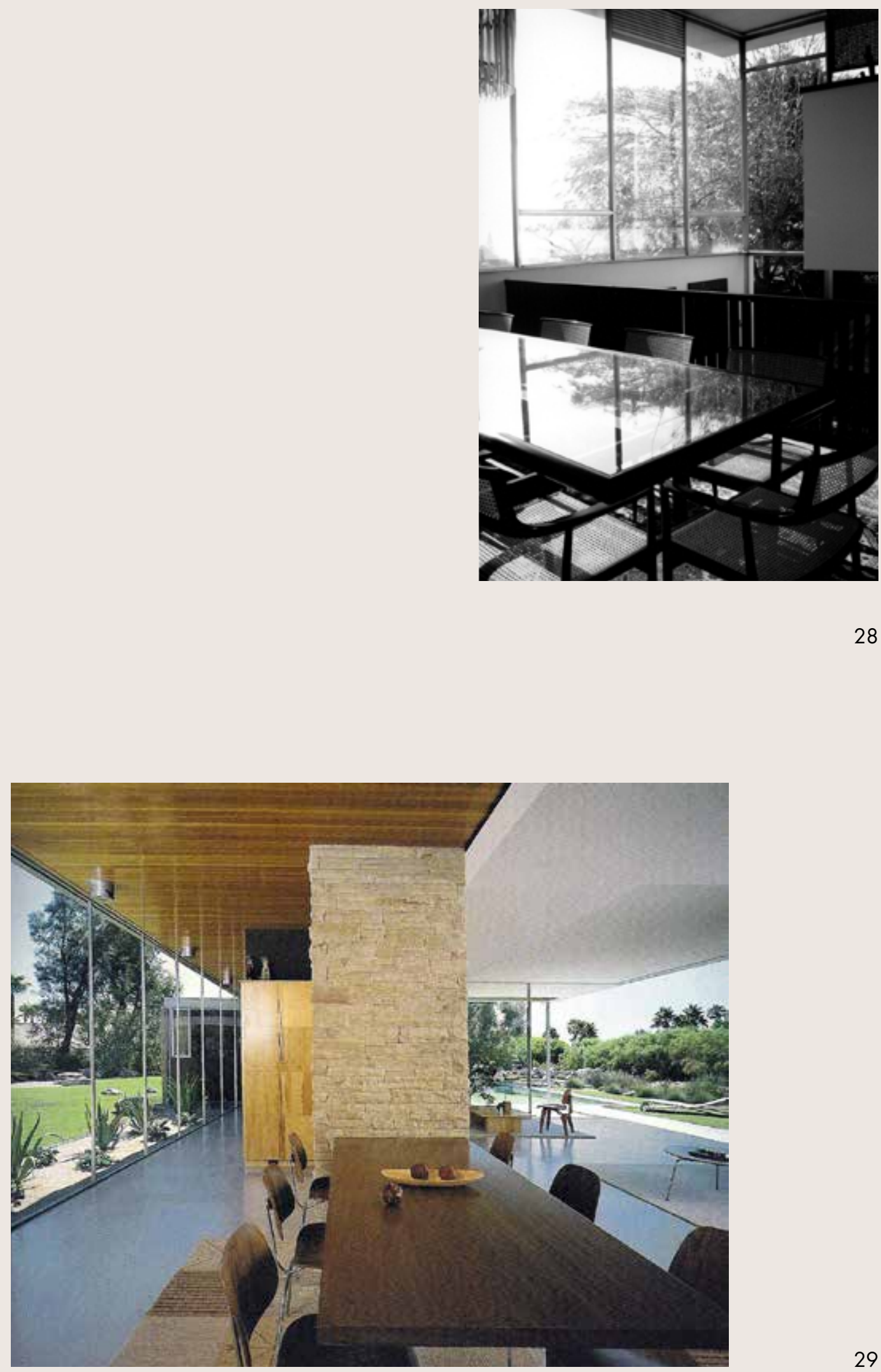

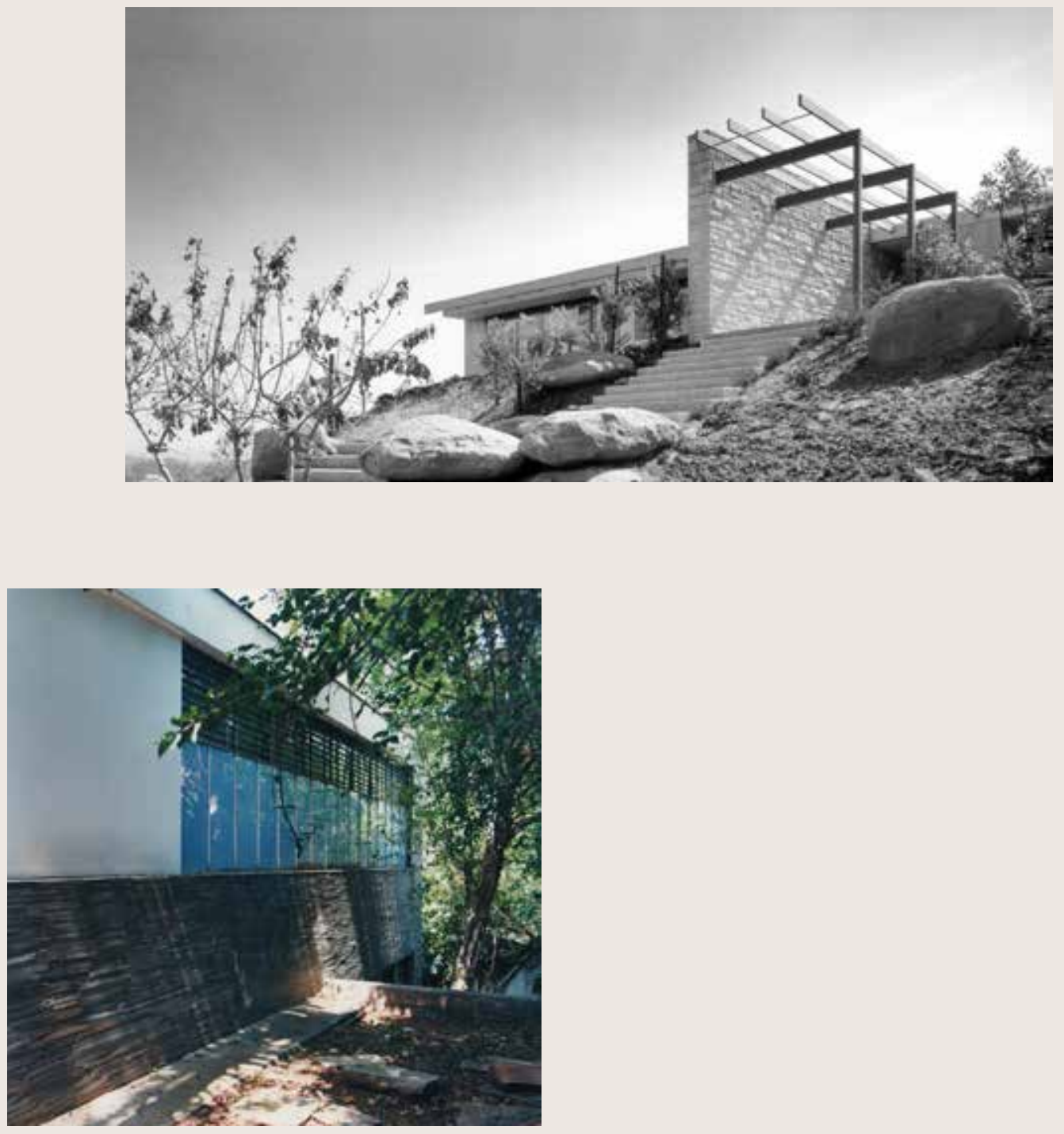

31

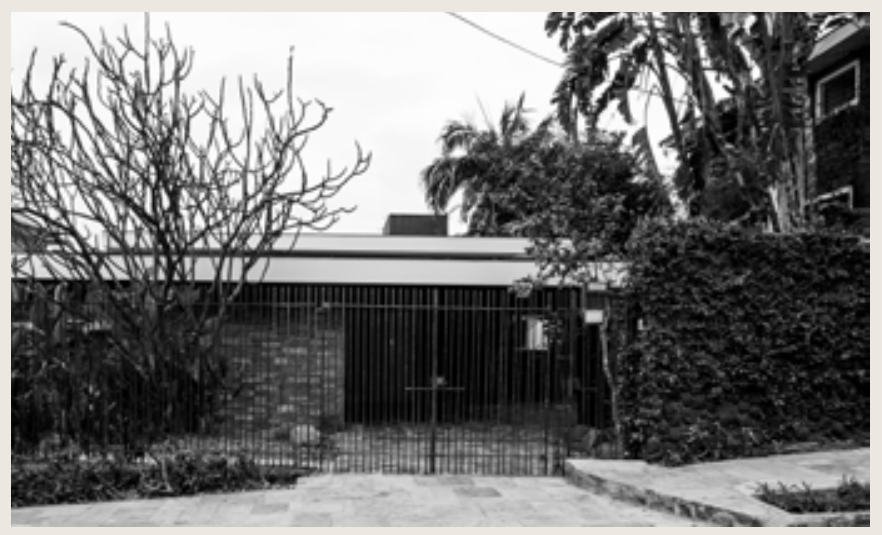



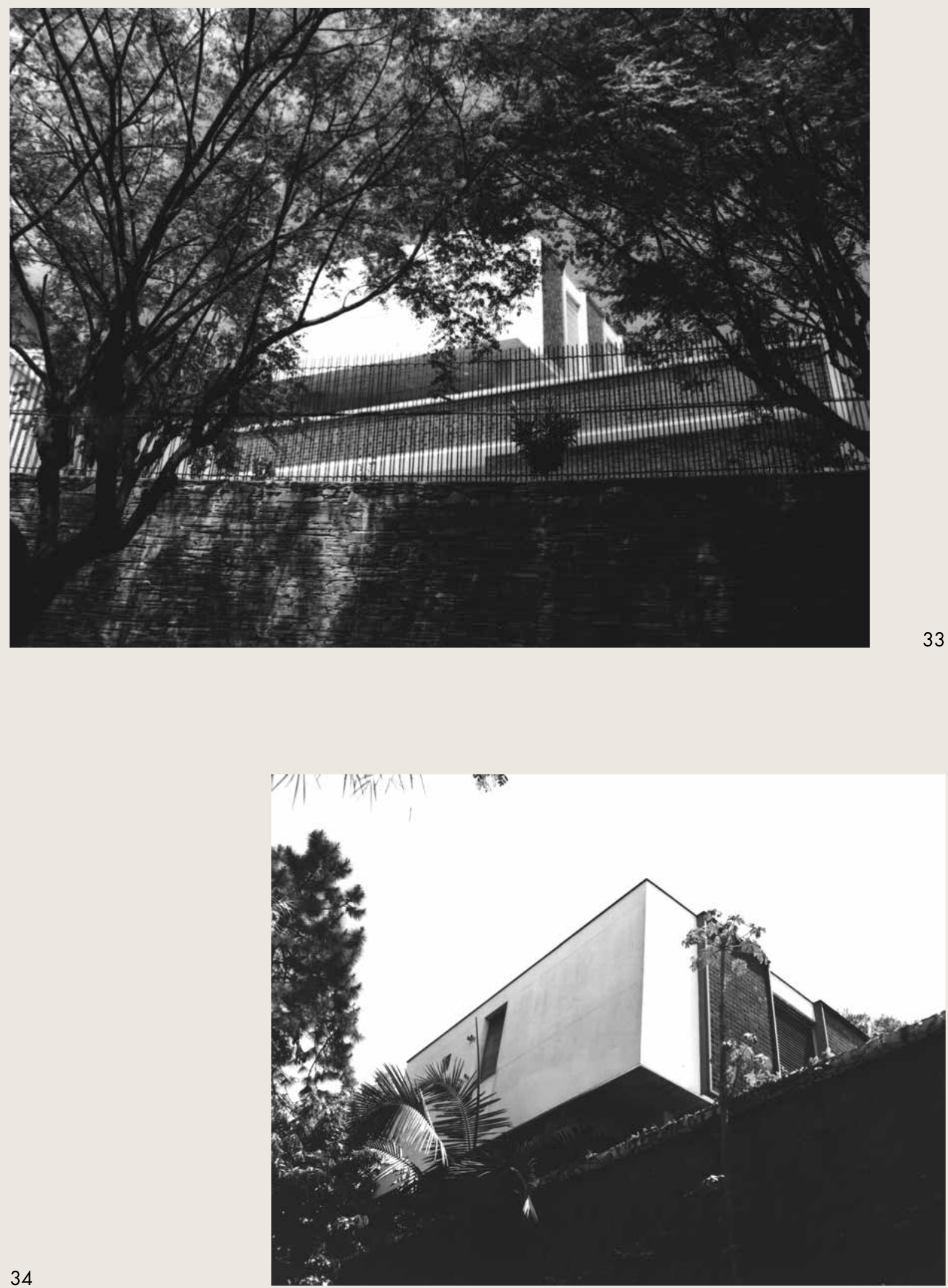

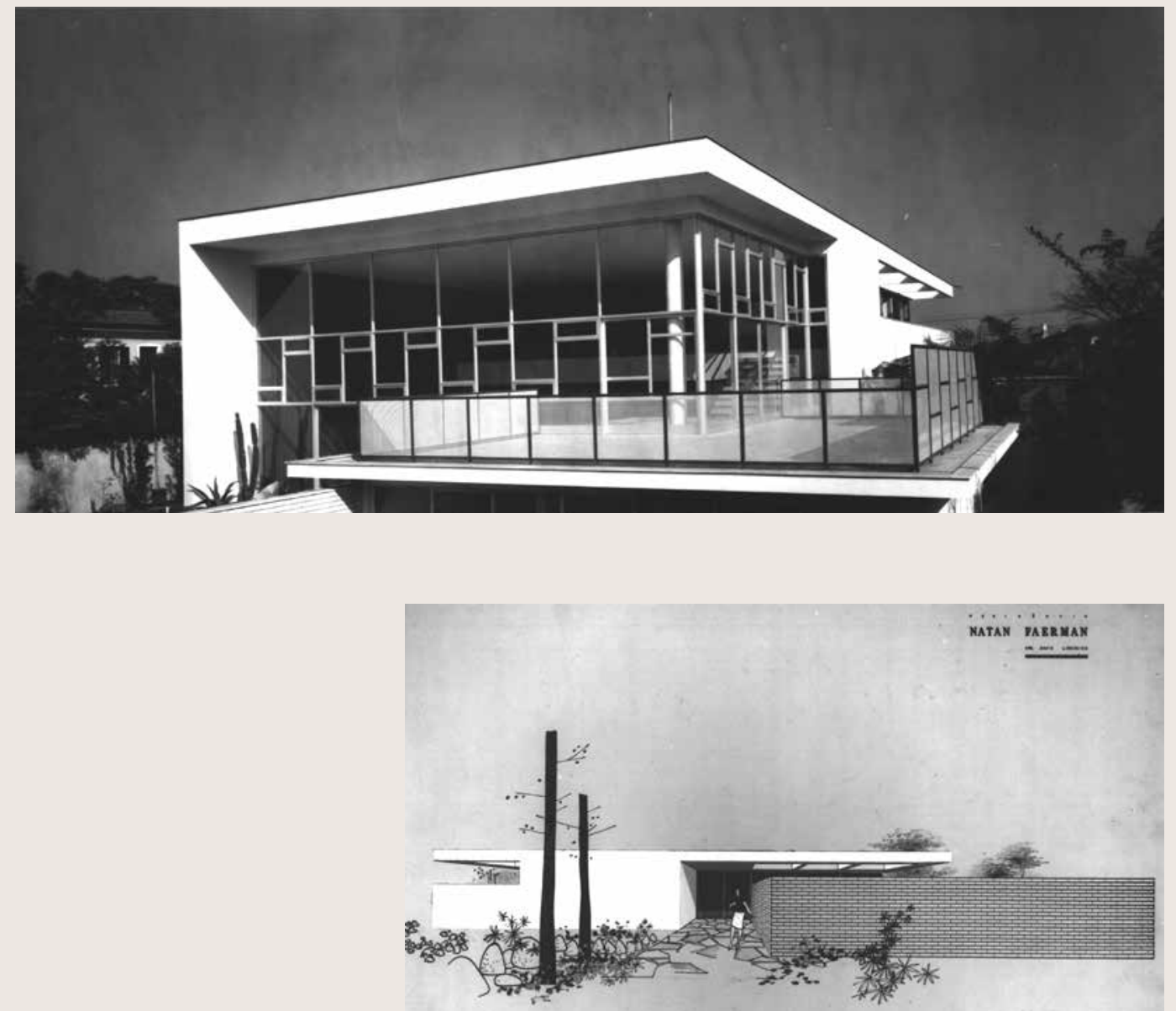


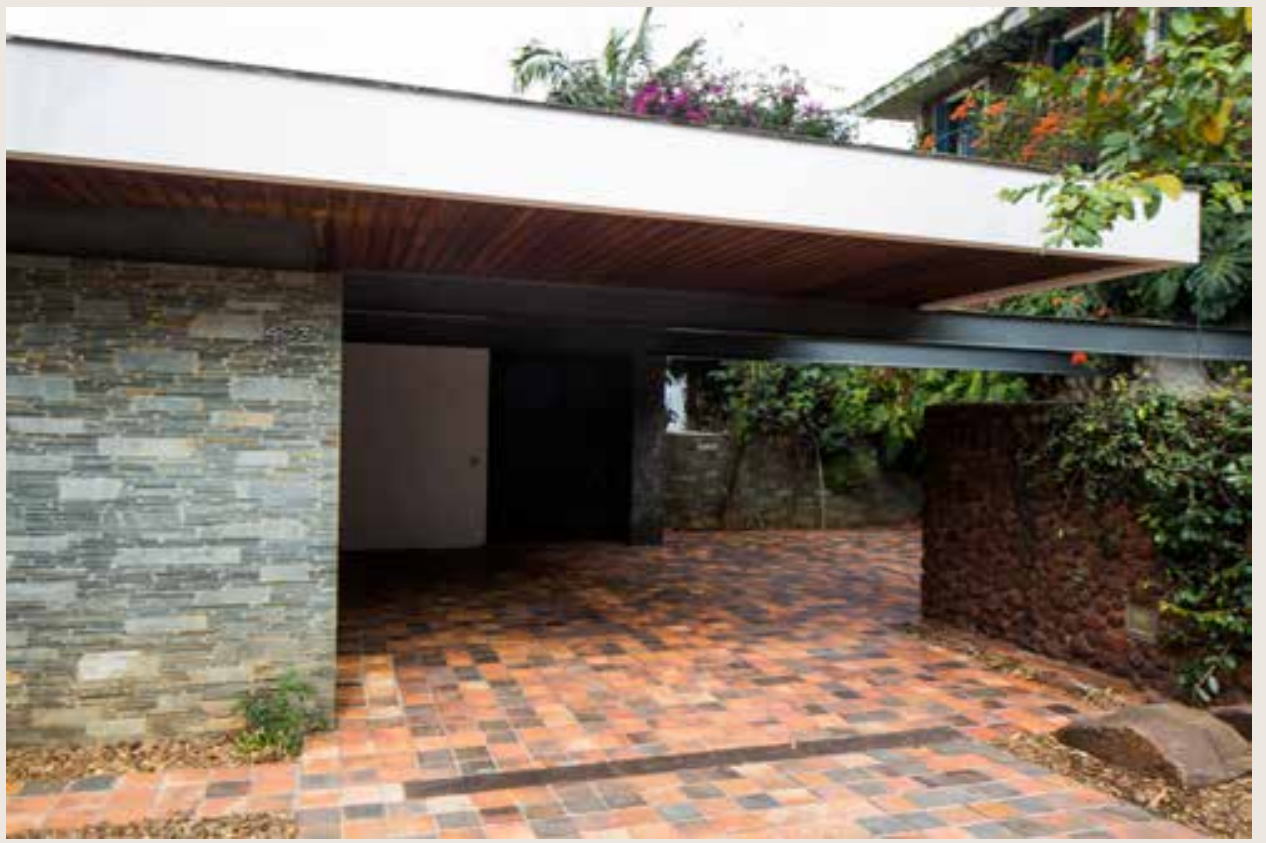


VISITA À CASA DO ARQUITETO 
“(...) Ali erigido, o edifício repousa sobre o solo rochoso. Repousando

sobre a rocha, a obra extrai dela o mistério encerrado em seu suporte

tosco, mas natural. Ali erigido, o edifício aguenta firme a tormenta que se desencadeia sobre seu teto e assim faz com que a tormenta se revele em sua violência. O lustro e a luminosidade da pedra, cujo brilho parece ser apenas um efeito do sol, evidenciam a luz do dia, a amplitude do céu, escuridão da noite. O firme alçar-se do templo torna visível o espaço invisível do ar. A estabilidade da obra contrasta com as ondas do mar, e a serenidade daquela põe em evidencia a fúria deste. A árvore e a grama, a águia e o touro, a cobra e o grilo adquirem dessa maneira sua forma distinta e aparecem como são. Os gregos designavam essa aparição e surgimento em si e em todas as coisas de physikós. Ela ilumina e explica também aquilo sobre que é em que o homem funda sua morada. Nós o chamamos de terra. $\bigcirc$ que essa palavra indica não deve ser associado nem à ideia de uma massa ou material sedimentado em algum lugar, nem à noção puramente astronômica de um planeta. A terra é aquilo de onde surgimento traz de volta e acolhe tudo o que surge sem violação. Nas coisas que surgem, a terra está presente como

o agente acolhedor. A obra-templo, ali erigida, abre um mundo e ao mesmo tempo volta a situá-lo sobre a terra, que somente então aparece como solo natal. Mas os homens e os animais, as plantas e as coisas, nunca estão presentes nem se conhecem como objetos imutáveis para depois proporcionarem a esse templo uma ambiência adequada, que um belo dia vem somar-se ao que já está lá. Estaremos mais perto do

que é se pensamos tudo isso às avessas, supondo, é claro, que, para começar, estejamos preparados para perceber como tudo nos aparece de outra maneira. Por que meramente pensar de modo inverso, só por fazê-lo não resolve nada. O templo, por simplesmente estar ali, dá às coisas sua face e aos homens a visão de si mesmos."

Martin Heidegger

A descrição como método foi a forma escolhida de aproximação e compreensão dessa casa, enquanto vazia ou habitada. Descrever é um modo de perceber com os olhos, mas sobretudo de contar uma experiência vivida a partir das visitas realizadas durante os anos de 2000 a 2004 - período de convívio com o arquiteto David Libeskind - e de 2016 - após a morte do arquiteto (2014) quando esta casa já estava completamente esvaziada dos seus objetos, fato 
que provocou o impacto e o desejo de retomar o objeto de pesquisa, agora, remontado.

A narrativa a partir dessa descrição pretende montar livres associações, que com o recurso das imagens procura revelar como é possível olhar uma obra de arquitetura. Mas a organização das imagens - parte deste trabaIho - é pura interpretação da autora, organizada de forma a revelar o universo cultural de referências para a construção da obra deste arquiteto.

Construção de uma narrativa acerca das experiências vividas, e, portanto, percebidas a partir do contato com o mundo das coisas, ligação entre aquilo que foi visto, porque era real, material, com o que foi percebido através da experiência com a casa e com a presença do próprio Libeskind na sua casa, somado ao que foi conhecido pelo estudo da sua obra no mestrado.

Entre os anos das visitas à casa, Libeskind era o único habitante do lugar e a narrativa está, portanto, circunscrita nos limites da existência solitária posta nessa relação casa-autor.

No período de realização do mestrado, entre os anos de 2000 e 2004 , houve uma série de encontros que se desdobraram em horas de conversas com o arquiteto. O levantamento do material realizado na época, a partir do contato com as fontes primárias da sua produção, foi, em muitas ocasiões acompanhado pelo próprio arquiteto, que já havia, de certo modo, iniciado uma organização preliminar da sua produção, desde que suas atividades práticas haviam se reduzido substancialmente devido à doença que o acometeu em finais dos anos 1990.

Essa foi a circunstância que possibilitou conhecer essa casa, visitá-la em companhia do seu autor, perceber a sua ocupação, suas dinâmicas e suas rotinas.

A casa havia se convertido numa espécie de museu, onde os objetos pessoais, obras de arte e peças do mobiliário pareciam figurações em companhia ao próprio autor da obra.

"A arquitetura moderna é um produto da civilização ocidental. Começou a tomar forma durante o fim do século XVIII com as revoluções democrática e industrial que produziram a era moderna. Como toda arquitetura, a moderna tentou criar um ambiente especial para a vida humana e compor uma imagem dos pensamentos e ações dos seres humanos como eles mesmos desejavam parecer. Nessas duas tentativas fundamentais, o homem moderno enfrentou dificuldades psíquicas sem paralelo no Ocidente desde o colapso de Roma. O modo de vida antigo, cristão, pré-industrial, pré-democrático, foi progressivamente se rom- 
pendo à sua volta, de modo que o homem obteve um lugar jamais ocu-

pado por um ser humano antes. Ao mesmo tempo, tornou-se um átomo minúsculo em um vasto mar de humanidade, um indivíduo que se reconhece como sendo definitivamente solitário. Portanto, vacilou entre o desejo frenético de encontrar algo mais amplo a que pertencer e a paixão igualmente avassaladora para expressar a sua própria individualidade e agir por conta própria. A arquitetura moderna refletiu as tensões desse estado mental e materializou o caráter da época que as gerou. Foi muito mais que um mero reflexo de sua sociedade. Como toda arte, revelou algumas verdades básicas da condição humana e, também, como toda arte, desempenhou um papel na mudança e reforma dessa própria condição. Desde o seu início, apresentou-nos a nós mesmos como homens modernos e nos disse o que somos e o que queremos ser."1

O reencontro com a obra de Libeskind no doutorado suscitou a possibilidade de propor uma outra forma de trabalho retomando a memória dessas conversas, desses encontros com o arquiteto podendo confrontar os dois momentos da casa - dois tempos sobrepostos - um deles em companhia da presença do seu habitante e idealizador e o outro tempo, após uma outra condição, a casa e todas as ausências que ali se estabeleceram. Esse olhar também se apoia em levantamentos fotográficos de vários momentos, contribuições realizadas ao longo do tempo, registros da casa e da sua ocupação. Essa iconografia possibilita rememorar o espaço outrora habitado e proceder à narrativa proposta, de certa forma reiterando as palavras de Argan: "a realidade do fato narrado é incontestavelmente diferente da realidade do fato acontecido, mas a narração que se faz hoje de fatos acontecidos no passado tem, para a vida que se vive hoje, um valor que o fato acontecido, como tal, não pode ter". ${ }^{2}$

O terreno em que está implantada a casa originou-se de um desmembramento da propriedade vizinha no bairro do Pacaembu. Com frente para duas ruas - Atibaia e Traipu -, o lote apresenta desnível aproximado de dez metros entre elas. Libeskind acomoda os vários planos da casa entre terraços e jardins, que são revelados pouco a pouco, escalonados a fim de amenizar o muro de arrimo para a rua de menor cota (Rua Traipu).

1 SCULLY JR., Vincent (1961). Arquitetura Moderna: a arquitetura da democracia. São Paulo: Editora Cosac \& Naify, 2002. p. 15

2 ARGAN, Giulio Carlo. História da arte como história da cidade. São Paulo: Martins Fontes, 1992. p. $25-26$ 
Em depoimento, Libeskind comentou sobre alguma restrição econômica na realização da casa. Contudo, mesmo contando com recursos mais escassos do que usualmente dispendidos pelos seus clientes na construção da maioria dos projetos residenciais, o arquiteto não sei viu impedido de colocar em prática seus desejos, concretizando de forma precisa e adequada a sua própria moradia.

A casa é aparentemente térrea. É assim que ela se apresenta a partir da vista da Rua Atibaia.

Bastante discreta, revela muito pouco do seu conteúdo, da sua forma, do seu programa ou da sua escala. Há desde esta vista muros com tratamentos distintos (pedra e ladrilho) que apenas permitem perceber a porta de acesso principal da casa, feita em madeira, com desenhos geométricos.

A horizontalidade predominante deste volume frontal é reforçada pelas vigas metálicas aparentes que correm sobre a garagem e fazem a conexão com o muro lateral.

A casa e seus limites, seus planos que demarcam a ocupação de um lote não são apenas o marco de uma representação, mas também de uma situação precisa: é uma casa urbana. A casa de um arquiteto cosmopolita. Os muros demarcam a realidade de um homem urbanizado habitando uma cidade em grande atividade, a metrópole de São Paulo.

A partir da Rua Atibaia a casa se mostra muito pouco. A casa é um muro, com um portão de vergalhões de aço brutos que remetem à própria ideia construtiva e material da obra. Duas vigas metálicas tipo "I" atravessam longitudinalmente sua porção frontal, completando a ideia anterior, mas agora enquanto fato acabado, indicam o acesso à casa.

A volumetria da casa permite uma leitura inicial com o predomínio da horizontalidade a partir da construção geométrica dos planos que definem os seus limites. Esses elementos horizontais e verticais recebem tratamentos de materiais diversos, como pedra, madeira, ladrilhos e vidro, mas não se restringem à uma questão plástico-formal de composição de fachada. Ao adentrar na casa é possível perceber que esses planos tratados formam uma continuidade no espaço e conformam os vazios interiores. Há uma complexidade entre todo esse conjunto de planos - verticais e horizontais - e das suas materialidades, que organizam os patamares de arranjo do programa da casa.

Completa o cenário a presença da natureza em distintas versões: uma árvore, um pau-ferro pré-existente no lote e que aí permaneceu como registro de um lugar passado e um jardim elevado posicionado na porção frontal da casa voltada para a Rua Atibaia. O jardim no nível do escritório e do acesso 
à área íntima e o jardim que conecta o pátio do ateliê na cota mais inferior da

casa, visualmente relacionada à Rua Traipu.

O acesso ao vestíbulo é marcado com uma porta magistral, de madeira entalhada com desenhos geométricos que separa em definitivo o que está fora, a cidade, o externo, do ambiente interior da casa.

Este nível da Rua Atibaia permite o acesso à casa e nele se conformam o vestíbulo, a sala de jantar, o lavabo, a copa e a cozinha.

Essa cota de chegada, que se acerta com a topografia da rua permite ao observador ter uma visão quase completa da casa. Trata-se de um piso intermediário, lugar por onde é possível mirar acima, abaixo e também perifericamente numa gama de espacialidades múltiplas, onde Libeskind apresenta o domínio do conjunto de elementos fundamentais do repertório maduro do arquiteto. Controle e rigor das alturas, das vistas, daquilo que pretende mostrar ou reservar para um vislumbre posterior através do caminhar pela casa.

Desta forma a casa se organiza em meios-níveis: acima da cota do acesso principal, se localiza o escritório e a área íntima com três dormitórios, sanitários e jardim lateral.

Na cota meio-nível abaixo do acesso principal está implantada a área social - distribuída em duas salas de estar: sala de estar 1 (pé-direito duplo), sala de estar 2, contígua ao bar, adega e lareira, e a área da piscina.

Neste mesmo nível se estende pela área externa o acesso para o nível inferior sob a área de estar, na cota da Rua Traipu, que abriga o ateliê, laboratório fotográfico, depósito, sanitário, lavanderia e dormitório e sanitários de empregados.

A casa é composta pela ortogonalidade entre os planos horizontais e verticais.

O aspecto predominantemente horizontal da casa é totalmente desconstruído pela verticalidade do pé direito duplo da Sala de estar 1, que se conecta visualmente com a Sala de jantar e com o escritório.

O horizontal está sempre dirigido para o tratamento atento e apurado dos planos com texturas e cores, predomínio do tectônico, do construído, do aconchego daquilo que é interior, das atividades que olham para o seu interior, da dinâmica da vida doméstica.

O vertical é transparente, banha-se pela luz total possibilitada pela fenestração que desenha o limite sutil da casa e sua franca abertura para a piscina. Aqui a intenção é a mescla do interior com o exterior, a intersecção com a paisagem, com o mundo de fora, ainda que delimitado pelas arestas do limite do terreno com as edificações vizinhas. 
Essa casa não olha a cidade, ela filtra para dentro de si o universo, a vida da cidade decodificada a partir dos elementos que remetem ao passado e ao futuro de Libeskind. Ele passaria em torno de 20 anos vivendo sozinho nessa casa até a sua morte. Assim, ela, pouco a pouco, assume uma natureza autobiográfica. A casa encarna a memória do arquiteto e da sua arquitetura. Ela presentifica o ato de reviver a sua trajetória. Os seus guardados, os arquivos que ali foram vistos pela pesquisadora: a casa abriga os vestígios de uma vida criativa, de um profissional atuante, com suas eleições e afinidades estéticas e afetivas.

Os materiais construtivos e de acabamento empregados na construção da casa apontam para o claro desejo de oferecer um repertório de distintas temperaturas para os ambientes da casa, com a intenção de proporcionar para cada situação, não apenas o apuro da resolução técnica térmica, mas a sensação do lugar.

Libeskind enfatiza, por exemplo, o canto da conversa, do aconchego, da intimidade nas interações que ocorriam junto ao bar, resultando num ambiente de pé direito mais baixo, com luz indireta, contíguo à lareira - lugar do fogo -aproveitando as variações de alturas dos degraus sob a escada.

Textura, cor, luz, sombra, altura, largura e uma coleção de materiais pesquisa tátil presente no tratamento dos diferentes planos dessa casa - também são tributários das investigações de Libeskind no campo das Artes Plásticas num momento de aprofundamento das composições abstratas, informais e matéricas dos anos 1960, no trânsito de Libeskind nas montagens das Bienais acompanhado por Danilo Di Prete ${ }^{3}$, e no encontro com a obra de Alberto Bur$\mathrm{ri}^{4}$, assunto que será retomado no trabalho.

O que se pretende revelar, mesmo que a partir da descrição apoiada nos

3 Danilo di Prete (Pisa, Itália 1911 - São Paulo, São Paulo, 1985). Pintor, artista visual, ilustrador e cartazista. Autodidata, inicia carreira aos 20 anos, na Itália. Integra, na Segunda Guerra Mundial (1939-1945), o Grupo de Artistas Italianos em Armas e, com eles, ilustra episódios da guerra na Albânia, Grécia e lugoslávia. Sua pintura no período é figurativa, e entre os temas que explora fora do grupo predominam marinhas, naturezas-mortas e retratos. Chega ao Brasil em 1946, fixa-se em São Paulo, e por quatro anos dedica-se à atividade publicitária. Em 1951, participa da $1^{a}$ Bienal Internacional de São Paulo e conquista o prêmio nacional de pintura, com o quadro Limões. Motivado a trazer artistas do pós-guerra europeu ao Brasil, ele teria sugerido a Ciccillo Matarazzo (1898 - 1977) a ideia de uma bienal nos moldes da de Veneza. O artista não é citado por Yolanda Penteado (1903 - 1983), esposa de Matarazzo, em suas memórias, nem por Antonio Bivar (1939), seu biógrafo, mas é consenso que ele atua no planejamento da exposição. Participa de outras doze bienais. Em 1965, volta a receber o prêmio nacional de pintura, na $8^{a}$ Bienal Internacional de São Paulo. In: ENCICLOPÉDIA Itaú Cultural de Arte e Cultura Brasileiras. São Paulo: Itaú Cultural.

4 Alberto Burri (Città di Castello, Itália, 1915 - Nice, França, 1995). Pintor e escultor foi considerado como uma figura-chave da arte do Pós-Guerra como Novo-realismo, Pós-minimalismo, 
elementos construtivos e concretos, sobretudo, é a relação entre o invólucro,

o espaço vazio e os objetos que ocupam este espaço, tendo como protagonista deste espaço o usuário, a partir da compreensão de que a habitação não é um espaço acabado e consolidado, mas sim a soma das peças dinâmicas que a compõe.

Assim, a consciência dos vínculos entre as formas de pensar, de ver o mundo, os modos de vida e as técnicas de projetar não são neutras, mas contem em si mesmas a capacidade de manobra crítica do trabalho do arquiteto.

Compreender o viver nessa casa, o permanecer e o estar nesse espaço projetado por seu próprio habitante apresenta uma possibilidade de investigação sobre modelos de ocupação que reiteram comportamentos e modos de ser. Há uma condição presente na casa, reflexo do paradigma do habitar, tanto na materialização da concepção dos espaços que se alinham com a cartilha moderna, quanto em sua ocupação, pois os móveis, objetos e sobretudo as obras de arte completam esse cenário.

Visitar a casa é visitar as suas idealizações, do ponto de vista da sua privacidade e dos desdobramentos dos diferentes modos de assimilação do pensamento contemporâneo. Muitas referências pertencem mais ao âmbito da cultura do que ao do estritamente disciplinar e propõe enfrentar uma reflexão sobre a forma de viver, de apropriar-se do espaço privado e, por extensão, chegar ao espaço público. Pensar através do olho do habitante, pela experiência real da casa e do doméstico - da vida que a contém, também é propor compreender a passagem do tempo na casa. ${ }^{5}$

As imagens escolhidas, fruto de levantamentos fotográficos de diver-

e Arte Póvera.

Depois da sua diplomação na Universidade de Perugia e sua precoce experiência voluntária na $2^{\text {a }}$. Guerra Mundial, ele foi enviado para a Líbia como combatente médico. Utilizando o limitado estoque de materiais disponíveis no campo, ele iniciou suas atividades de pintura, sem nenhuma referência acadêmica e aos poucos abandonou a medicina em favor da pintura.

Sua pesquisa artística se tornou altamente pessoal num tempo bastante curto: entre 1948 e 1950 quando começou a experimentar materiais pouco usuais e não ortodoxos como areia, zinco, espuma, alumínio, cola, tecidos e outros. É considerado um dos maiores representantes da arte informal da segunda metade do século XX, recebendo sua maior exibição retrospectiva - a primeira nos EUA em 35 anos e talvez a mais completa já montada - que exibiu o seu trabalho pioneiro explorando a beleza e a complexidade na qual está baseado o complexo processo de produção de Burri. A exibição que aconteceu no Museu Guggenheim, entre 2015 e 2016 posicionou o artista como uma figura protagonista central e singular na arte da pós Segunda Guerra Mundial.

In: ENCICLOPÉDIA Itaú Cultural de Arte e Cultura Brasileiras. São Paulo: Itaú Cultural.

5 Em Nietzsche, a morte de deus e da metafisica ocidental marcam o principio de um pensamento da afirmação, da vontade de poder, que tem no "super-homem" e na teoria do "eterno retorno" sua conclusão propositiva. (...) ○ tempo deste sujeito deixa de ser o escatológico, próprio da tradição judaico-cristã, para propor um retorno ao tempo cíclico dionisíaco. (...) A ideia do eter- 
sos períodos de existência da casa congelam cenas e apropriações do espaço que remetem à ideia de que a casa foi se construindo por ela mesma, a partir do uso, do desgaste dos materiais, da incorporação de novos objetos e da ressignificação do espaço decorrente dessas camadas de tempo, ou do próprio habitar.

Analisar a casa do arquiteto é, além de percebê-la como este trabalho propõe - sob um olhar que convoca elementos de leitura provenientes de outros campos de linguagem - também reconhecer a presença dos outros projetos de Libeskind ali reunidos.

Nesse sentido, há quatro projetos de residências unifamiliares contemporâneos à casa do Pacaembu que reverberam nesta, sobretudo na pesquisa dos materiais empregados para o tratamento dos planos, no acerto das geometrias e como o arranjo dos elementos sintáticos da arquitetura já estavam presentes ali revelando a pesquisa realizada por Libeskind por uma ambiência e por uma expressão genuínas que em 1961 já se apresentavam com bastante maturidade, postas por um caráter muito pessoal dessa arquitetura.

As residências José Felix Louza, de 1952, em Goiânia; Antônio Mauricio da Rocha, de 1957, em São Paulo; Joseph Khalil Skaf, de 1958 e Natan Faermann, de 1958, também em São Paulo são projetos que dialogam intensamente entre si e com a casa de Libeskind, amparados por um certo idealismo cultural e de métodos próprios da expressão moderna.

Não obstante a condição cronológica e histórica, nessas casas é claramente possível detectar aproximações com o discurso dominante da Arquitetura Moderna Brasileira e também localizar referências internacionais bastante presentes, códigos estes que contribuíram de forma aguda na definição de uma linguagem para a produção residencial unifamiliar dos anos 1950, com destaque para um grupo de arquitetos representantes da modernidade paulista ao qual Libeskind fazia parte - por exemplo, Rino Levi e Oswaldo Bratke, este último amigo pessoal de Libeskind.

A residência José Felix Louza, de 1952, foi a segunda residência construída do arquiteto apresentando um primeiro ensaio da linguagem que se

no retorno para a suposição de que a vida é reversível a partir de uma imagem de uma ampuIheta. Ainda que um tanto angustiante, esta hipótese é pra Nietzsche uma forma de instalar no homem o prazer, como se tal situação o impulsionasse a compreender a intensidade de cada instante exigindo um compromisso com o presente, de modo que sempre iria querer repetir a experiência. É a recuperação da fugacidade do devir frente à estabilidade do ser, (...)o eterno retorno é em Nietzsche a recuperação do perecível e mutável pelo homem, uma recuperação do presente frente à tirania do futuro divino ou ao passado tradicional, uma volta à vida e ao cultivo das paixões. In: ÁBALOS, Iñaki. La Buena Vida - visita guiada a las casas de la modernidade. Barcelona: Editorial Gustavo Gilli, 2000. p. 25 
afirmaria nos próximos projetos de residência unifamiliar. Esta casa já guarda

uma distância das primeiras experimentações presentes na residência Ângelo Aurélio Rezende Lobo, de 1952, em Belo Horizonte. Neste caso, Libeskind ainda apresentava influências plásticas e de soluções como o uso de pilotis, telhado em forma de "asa de andorinha" e plasticidade nas formas como clara citação à obra de Oscar Niemeyer ${ }^{6}$, forte presença no início da carreira do arquiteto, ainda em Belo Horizonte.

Segundo Hugo Segawa, algumas temáticas são reincidentes nesses projetos: a presença de pátios e exteriores ajardinados, - que funcionam como conectores dos diversos cômodos das áreas sociais e íntimas; a clara setorização funcional dos ambientes domésticos; e a hegemonia formal com uso de planos e volumetrias.

Os elementos que permitiram, de forma conclusiva, tecer associações entre a obra de Libeskind e exemplares das casas californianas e por extensão, com as obras de Oswaldo Bratke e Rino Levi são muito mais de compreensão de linguagem - como os conceitos de espaços fluidos, espaços de transição, diálogo entre os espaços interiores e exteriores, uso de diferentes materiais e o tratamento das superfícies dos planos, como na lição deixada por Marcel Breuer, "O espaço (...) nunca está completo e finito. Ele está em movimento, conectado com os próximos espaços, e com os espaços seguintes - e com o espaço infinito. Ele é materialmente definido pelo plano, ou por paredes de alvenaria e tijolo (...) pelo requadro estrutural, por um domo, ou por uma lâmina de vidro. Mas definido apenas, e não isolado (...). Nós temos uma nova experiência espacial (hoje): o espaço em movimento, o espaço fluido. E porque nós temos essa nova experiência não estamos muito mais envolvidos com o pequeno detalhe, mas com a grande unidade deste novo e maravilhoso meio: o espaço fluido que nós tentamos moldar."

A Residência Jose Felix Louza foi concluída em 1952, imediatamente após Libeskind concluir o curso na Escola de Arquitetura da Universidade

6 Qualquer pessoa que ande por uma cidade média no Brasil encontrará, se a intensa especulação imobiliária ainda não os tiver destruído, bairros residenciais construídos nos anos 1950, em que se encontram inúmeras casas à la Niemeyer: pilotis em $V$, coberturas em tesoura invertida, a elevação do primeiro piso para permitir uma rampa em curva, um indefectível jardim de seixos rolados à la Burle Marx, etc. Certamente não são obras de Niemeyer e, na maioria das vezes, nem sequer de arquitetos. De uma perspectiva sociológica estrita essas obras serão consideradas kitsch. Para nós esse fenômeno deveria interessar em outra perspectiva. Importa assinalar aí que, num dado momento da história do país, a classe média, inclusive das pequenas cidades do interior, teve o moderno como valor. E, mais surpreendente, tinha uma imagem clara de um projeto arquitetônico - o de Niemeyer ou da "arquitetura brasileira" como expressão desse valor. MARTINS, Carlos Alberto Ferreira. "Há algo de irracional..." Notas sobre a historiografia da arquitetura brasileira (1999). p. 160 
Federal de Minas Gerais, e só chegaria em São Paulo um ano depois, no ano de 1953. Libeskind travou contatos em Goiânia por meio de um amigo da infância, Moisés Fux, que se formou engenheiro também em Belo Horizonte e tornou-se um grande empresário em Goiás, passando a indicar clientes para Libeskind.

Nas palavras do arquiteto, as casas de Goiânia são "introvertidas" - fechadas em si mesmas, com jardins internos e fachadas cegas, um primeiro indício que a conecta com as outras 3 residências reunidas aqui. Essas fachadas cegas são compostas por volumes diluídos em planos verticais que diferem nos tratamentos e na escolha de materiais. Esta residência está implantada em lote de esquina e não apresenta aberturas para o exterior, pois encontra-se em local de considerável ruído pela confluência de duas ruas de certo movimento. Libeskind também utiliza da mesma decisão de projeto para sua residência no Pacaembu, mesmo que se trate de uma rua absolutamente silenciosa. Essa decisão, parece, nesses casos, partilharem de uma vontade de desnudar a casa para dentro do lote, de certa forma ignorando a rua, pouco se revelando à condição pública.

Na casa de Goiânia as faces paralelas às ruas são compostas por planos totalmente fechados compostos de materiais à vista, aproveitando-se ao máximo as qualidades estéticas e a expressão tátil desses materiais, como a cerâmica e o elemento vazado.

Vale dizer que as cerâmicas e os azulejos empregados por Libeskind como tratamento dos planos nos seus projetos - fato que extrapola o programa residencial - são investigações artísticas realizadas pelo arquiteto, oportunidade para experimentar plasticamente algumas soluções.

A composição dos planos externos que acentua o caráter horizontal do volume retangular para a rua é um ponto comum na concepção desse conjunto de residências, sendo que na Felix Louza essa operação se dá a partir do volume resultante dessa composição. Nota-se o uso de um plano vertical que se fragmenta em três planos ao longo da fachada norte, obedecendo uma hierarquia de posicionamento e recuos que é arrematada pelo plano da fachada oeste. O primeiro plano, próximo à rua é de tijolos e está ligado ao terceiro plano - de revestimento cerâmico - pelo plano intermediário e semitransparente de elementos vazados, que faz a transição visual entre os outros dois.

Essa condição de transparências de naturezas diversas que se alteram criam um conjunto riquíssimo de quadros, constituintes do todo que se dispõem e se integra, e que partilha de um recurso perceptível nos outros projetos desse grupo de casas: o plano alongado, ou o plano que transpassa a 
intersecção com outro plano. Esse plano contínuo se alonga, com referências

aos princípios neoplasticistas, como comentado por Norberg-Schulz sobre a casa Schröder: "A nova arquitetura atravessou o muro, e ao fazê-lo eliminou por completo o divórcio entre dentro e fora. Os muros já não suportam cargas: limitam-se a ser pontos de apoio. E, como resultado, gerou-se uma nova planta aberta, totalmente diferente da planta clássica devido à interpenetração do espaço interior e exterior."

Outra particularidade que reúne essas casas dentro de um grupo, como tese, é o fato de que os ambientes internos da casa desfrutam do contato direto com o exterior, através de aberturas generosas, pátios e jardins, elementos bastante recorrentes no discurso da arquitetura moderna brasileira, ainda que sobre a ideia dos pátios e a relação com as casas de Rino Levi se demonstre na condição de "aprisionamento" do exterior no interior.

Os espaços de transição foram amplamente explorados nos projetos de habitação unifamiliar da arquitetura moderna por vários arquitetos, e dois exemplos significativos e referenciais para Libeskind são Richard Neutra ${ }^{8}$ e Oswald Bratke. Na obra de ambos está presente o estabelecimento de uma relação especifica entre arquitetura-natureza e interior-exterior, principalmente através da continuidade visual entre eles, ou seja, na maneira como estes espaços abertos são capturados pelo corpo da arquitetura.

Estes espaços são elementos de projeto que apareceram com muita força na arquitetura da década de 1950, como pode ser comprovado nos exemplos do programa The Case Study Houses ${ }^{9}$. A diluição dos limites entre interior

7 SCHULZ, Norberg (2000). Los pricipios de la arquitectura moderna: sobre la nueva tradición del siglo XX. Estudos Universitarios de Arquitectura. Barcelona: Editora Reverté, S.A. 2005. p. 71

8 Richard Neutra (1892-1970), seguidor de Adolf Loos e Frank Lloyd Wright, muda-se em 1923 para os EUA, e se instala em Los Angeles, onde trabalha com Rudolph Michael Schindler. Desde então se dedica a realizar sua característica arquitetura de vilas de formas transparentes e dinâmicas, próximas a dos padrões de Le Corbusier, Mies, Wright e do neoplasticismo. Depois da Segunda Guerra Mundial chega ao ápice de sua produção com obras como as casas Kaufmann Desert, em Palm Springs (1946-1948), e Tremaine, em Santa Bárbara (1947-1948).

9 Em 1945, John Entenza lança por meio da revista Arts \& Architecture um ambicioso programa chamado The Case Study Houses, que no transcorrer dos 19 anos seguintes construiu nos arredores de Los Angeles, com o patrocínio de empresas do ramos da construção civil, 24 dos 36 projetos publicados na revista. Os arquitetos eram especialmente convidados para o programa e tinham como obrigação básica experimentar as novas possibilidades para as residências oferecidas pelos novos padrões de industrialização obtidos no pós-guerra. O programa desmistificou e popularizou a estética do movimento moderno, assim como engrandeceu mundialmente o lifestyle californiano. Entre os arquitetos que participaram deste programa figuravam nomes célebres, como Richard Neutra, que projetou uma Case Study House para o próprio Entenza. Craig Ellwood (premiado na II Bienal de São Paulo, de 1953), que projetou três aclamados projetos para o programa, Charles e Ray Eames, Edward Killingsworth e Pierre Koenig, premiado na VI Bienal de Sao Paulo, de 1961. As casas produzidas naqueles anos 
e exterior, e a luminosidade e ventilação generosas que foram propostas pelos arquitetos envolvidos com os projetos dessas casas, estabeleceram um novo padrão de morar na Califórnia, reforçado pela não compartimentação do programa residencial através da associação dos espaços e das atividades cotidianas.

"Todos nós, cujas carreiras começaram pouco antes ou pouco depois da Segunda Guerra Mundial, estávamos fazendo isso. Estávamos destruindo os valores estabelecidos. Estávamos questionando o que era a casa, o que era o lar. Era um processo destrutivo assim como um processo construtivo." ${ }^{10}$

A potencialização desse pressuposto está vinculada à ambígua identidade dos dois espaços, onde um está sutilmente ligado ao outro através de interpenetrações recíprocas. Isso só é possível graças à utilização de divisórias transparentes ou vazadas.

Ainda em relação à adoção dos pátios internos, ou outros elementos de transição entre o espaço interior e o espaço exterior, cabe ressaltar a individualidade dessas casas, apontando que nada tem em comum com os programas de investigação dos arquitetos modernos ao redor do objetivo de obter tipologias sistematizadas de baixo custo.

Pela residência Antônio Mauricio da Rocha, Libeskind recebeu, em 1960, um ano antes do projeto da sua residência no Pacaembu, o Prêmio Prefeitura de São Paulo conferido pelo Salão de Arte Moderna, seção de Arquitetura.

Essa casa, amplamente publicada em revistas especializadas da época, causou impacto pela espacialidade banhada de luz e pelo uso contrastante de materiais, cores e texturas, conforme pode-se observar em matéria da revista Casa e Jardim n.92, de 1962: "A luz entra profusamente através de largas portas e janelas de vidro, dentro de uma composição linear simples e audaciosa ao mesmo tempo. As paredes geralmente nuas dispensam ornamentos supérfluos que possam romper o despojamento voluntário do conjunto. A cor desempenha um papel importantíssimo; diversos coloridos criam contrastes

tiveram a coragem de propor a reorganização dos espaços internos em função da superação dos velhos estereótipos domésticos e familiares da conservadora sociedade americana. Nesta arquitetura, profundamente influenciada por Mies van der Rohe, tudo gira em torno do conceito, muito difundido por ele, de espaço fluido e continuo (free flow of space), predominantemente horizontal. 
imprevistos, modificando os espaços, sugerindo novos limites. A textura va-

riada dos diversos materiais de revestimento e a disposição geométrica das linhas vêm acentuar a impressão de dinamismo criada pela arquitetura e decoração modernas. $\bigcirc$ jogo de linhas e volumes adequadamente distribuídas cria um equilíbrio muito agradável à vista."

Ponto em comum entre esta casa e a residência do arquiteto, é o volume retangular que se estende no sentido horizontal, em blocos compactos, destacados pela variedade de materiais empregados, como tijolos de cerâmica, vidro, pedras e divisórias de madeira.

Outro aspecto que as une é o programa que se distribui de forma fluida, com a integração plena entre os setores social, íntimo e de serviços garantida pelo vestíbulo do acesso principal, de onde se pode atingir qualquer setor da residência sem cruzar os demais; o mesmo vestíbulo que articula, também garante o perfeito isolamento desses setores. Ainda, o setor de serviço possui um pátio particular, ou coradouro, espécie de quintal, espaço frequente nos projetos residenciais de Libeskind, já visto na residência Spartaco Vial, de 1956.

As experiências plástico-matéricas alcançaram grande expressividade na residência Natan Faerman, projeto de 1958, resultado da busca por uma arquitetura que para além das resoluções funcionais e programáticas perseguia a linguagem de uma expressão implícita.

Este caráter da arquitetura perseguido por Libeskind já revelava a esta altura um processo de sedimentação da sua formação para muito além das lições da escola de arquitetura.

É possível perceber a presença de Minas Gerais, sobretudo de Guignard, no seu procedimento do risco com lápis de grafite dura, preciso, rigoroso, mas que escapa, na imaginação, das amarras acadêmicas. "Esse interesse por uma grande transformação provocada pelo paulatino abandono da mímese da realidade e pela busca de novos tipos de expressão no mundo da máquina, da geometria, da matéria, da mente e dos sonhos, com o objetivo de romper e diluir as imagens convencionais do mundo para promover formas totalmente novas. Os recursos básicos dessa transformação foram os diversos mecanismos gerados pela abstração para suplantar a mímese nas artes representativas: invenção, conceituação, simplificação, elementarismo, justaposição, fragmentação, interpenetração, simultaneidade, associação ou colagem. (...) A crise da visão estabelecida das coisas e a negação da mímese resultam em uma festa dos sentidos: a nova arte dedicar-se-á a estimular a relação entre a obra e o receptor a partir do ponto de vista dos mecanismos da percepção."11 
Nas residências Natan Faerman e David Libeskind há uma preocupação pela recuperação da expressividade e pela procura de uma certa monumentalidade, o que na arquitetura moderna significa um ressurgimento de um problema irresoluto - o do "caráter" -, exposto na segunda metade do século XVIII e marginalizado pelo movimento moderno. ${ }^{12}$

Da mesma forma que na residência José Felix Louza, de 1952, Libeskind utiliza o muro de proteção entre a casa e a rua mais baixo que o volume principal, reforçando a ideia de que a casa se fecha para fora e volta-se para si mesma, aberta para os seus espaços internos de pátios e jardins, reiterando os aspectos já apontados anteriormente.

O vestíbulo se expande em três momentos e se transforma em um eixo longitudinal - uma grande faixa de transição dos espaços abertos e sociais para os espaços compartimentados e mais privados. Assim como na casa de Libeskind, um desnível configura uma outra cota, que incorpora a lareira e o acesso ao setor intimo da casa, o qual se desenvolve no plano elevado.

É grande a diversidade de materiais empregados nos pisos e nos elementos de fechamento e separação dos ambientes. Materiais como a pedra, a madeira e o mármore aqui também comparecem e contribuem para configurar os ambientes, permitindo uma leitura muito clara, porem sutil, dos espaços, que, embora contínuos, ainda guardam, cada um, a sua própria identidade. Isso ocorre com o bloco delimitado pelo vestíbulo, sala de estar, lareira e sala de jantar, que ocupa um espaço único, continuo e fluido, mas com demarcações distintas através do uso de diferentes materiais no piso.

No emprego dessa gama de alternativas expressivas há um risco, pois, o conjunto poderia resultar em excessos, por vezes, num "expressionismo" tão veementemente refutado pela arquitetura moderna. Mas no caso específico

São Paulo: Editora G. Gilli, 2012. p. 15

12 Ibidem, p. 79. "Na realidade, as próprias convicções da arquitetura moderna foram convertendo-se nos maiores obstáculos para uma "expressão monumental". Nesse sentido, a arquitetura moderna distinguiu-se por sua vontade de negar a expressão como qualidade autônoma da forma. O conceito de caráter, que já atingia toda a história, seguiu evoluindo ao longo do século XIX, (...) que no final da tradição acadêmica e inicio do funcionalismo moderno, entende caráter como "identidade entre a expressão arquitetônica e a expressão moral do programa." (...) Assim, os próprios conceitos básicos e recursos formais da arquitetura moderna - expressividade por meio de negação, ausência de caráter, procura de protótipos, anti-historicismo, desejo de romper com as convenções, defesa da cobertura plana - eram motivados por suas contradições a fim de atingir uma maior expressividade. A partir da década de 1930, e especialmente depois da Segunda Guerra Mundial, entra em crise a pretensão de que o arquiteto não tem necessidade de acrescentar nada à precisão técnica e funcional do objeto para fazê-lo instrumento de intenções estéticas. É também nesse período que se comprova a impossibilidade de atingir a monumentalidade seguindo estritamente os princípios do urbanismo racionalista e anti-historicista. 
de Libeskind se trata de uma fusão entre Arte e Arquitetura, associações onde

nem uma, nem outra, comparecem como forma de complementação entre si, mas uma e outra são uma coisa só.

Nesse caso existe uma delicadeza que "alivia" o risco colocado acima, e isto é possível graças ao rigor, um gosto profundo pela feitura da arquitetura, arriscaria dizer, um processo quase autodidata exposto por algo que extrapola a técnica e os cânones da realização de uma arquitetura de qualidade. Havia neste processo uma exploração pessoal, e isso é colocado como tese, que, na sua casa, mesmo após a sua morte e o seu posterior esvaziamento, este caráter, ou esta vida ainda persiste.

Então as fachadas não revelam nada, porque o que a casa é ou, segundo L. Kahn, "o que ela quer ser", só se revela à medida que o percurso acontece e todas as coisas negligenciadas da arquitetura também são convocadas para vivenciar este espaço.

Mas a casa do arquiteto também possibilita afirmar a sua individualidade, seu próprio mundo interior, "a casa como o império do eu", pois o habitante é o próprio autor da obra convertido em habitante solitário.

Voltando a percorrer os espaços da casa de Libeskind, há um sentido essencial na presença do seu escritório como ponto estratégico na casa.

Este ambiente, além de ter uma localização privilegiada, de onde é possível ter um domínio visual para outros ambientes - Sala de Jantar, Sala de estar 1 (pé direito duplo), vestíbulo de acesso à casa e acesso para área íntima e ainda uma vista parcial para a lateral da casa, representa o centro de onde a energia produtiva de outrora passou a ser, em seus últimos anos de vida, o motor de ânimo para organizar a sua produção, quando sua condição de saúde o impedia de trabalhar. Lugar do labor, mas também da criação.

É um recinto com posição estratégica na casa, que comporta uma mesa de trabalho, uma mesa de reuniões, um móvel aparador que também serve como guarda-corpo e uma estante que ocupa toda a parede oposta ao acesso principal.

Na estante estão guardadas relíquias da vida do profissional: inúmeras pastas azuis e verdes, cada qual etiquetadas e enumeradas como que se ao longo de uma vida produtiva uma outra vida das memórias já se construísse pelas mãos do arquiteto: lenta, paciente, caprichosa.

Este era o espaço de figuração central da mistura entre vida, arte e arquitetura, lugar onde o arquiteto partilhava seu mundo particular materializado em fotos, pequenas anotações, agendas recheadas de contatos, desenhos, croquis, livros, revistas, gravuras, telas, objetos que se dividia entre apego emocional ou valor real. 
Libeskind sentado à sua mesa aguardava pacientemente alguém que compartilhasse desse seu mundo da casa, registro da ambiguidade entre a sua própria biografia que se confundia com a história da casa. Mas a sua obra seguia, indiferente a esse acontecimento. A obra é um auto registro do tempo. Ela revela tudo, desnuda costumes, políticas e hábitos. Mostra-se ao mundo escancarada com a sua verdade e através dela o arquiteto se expõe, comprometido com as suas motivações e o rigor para alcançá-las. A sua espera fora recompensada através das horas de contato com sua própria obra, agora democratizada, exposta, revelada, difundida.

Na sua casa, seu habitat-hábito-do-mundo, o seu próprio método experimentado. Essa foi sua 24․ casa construída e seu 41․ projeto, dentre vários outros programas arquitetônicos por ele desenvolvidos.

Em 1961, ano de inauguração da casa, aproximadamente vinte anos já haviam transcorridos desde que Libeskind saíra de Belo Horizonte, recém-formado, e mais de uma década da consolidação do seu grande sucesso construído na metrópole paulistana: o Conjunto Nacional, que cabe pontuar, não foi reconhecido pela crítica de imediato.

A elaboração de uma tese sobre a casa passa pelo desafio de procurar compreendê-la em 1961, recém-concluída e habitada pela família; o que ela representou através da presença do seu morador, que habitou posteriormente sozinho, e, finalmente, o que ela ainda representa, vazia.

O ambiente vivo através do olhar de um visitante, guiado pelo próprio autor possibilita perceber essa arquitetura feita de narrativas.

$\bigcirc$ arquiteto-artista não verbalizava quase nada, afinal, dizer muita coisa sobre a sua criação seria um excesso. Libeskind preferia contar histórias e casos, liberar aos poucos pequenos detalhes e quase não falar da sua produção, como que se ao falar da vida e dos episódios em torno da arquitetura alimentasse com maior riqueza a sua própria obra.

Esse fato, que parece de menor importância convoca em si exatamente o que se pode afirmar como um dos pressupostos para este trabalho: como Libeskind fez a síntese através das relações externas.

Aos poucos o arquiteto revelou referências e em sua estante repousava já bastante gasto um belo volume sobre a obra de Richard Neutra. Neutra, que segundo Libeskind, fora sua grande referência, ao lado de Mies e de Wright. Neutra e Mies, assim como outros arquitetos modernos haviam sido apresentados para o jovem Libeskind na Universidade, através de raríssimas publicações que chegavam, àquela época (década de 1940) até as suas mãos.

A conexão entre os personagens leva a compreender a genealogia da 
formação, o campo das ideias, o lugar dos enfrentamentos e as respostas dadas nas soluções espaciais que afirmam ideais de uma época, momento de grande crédito na cultura e no poder do crescimento e no avanço econômico, mas, sobretudo, na força da arquitetura enquanto lugar de reflexões sobre o ser, o habitar, sobre construir cidades, sobre o estar em sociedade.

Libeskind era esse homem urbano que acreditava no poder da arquitetura enquanto um discurso forte, amparado pela arte, pelas manifestações culturais, pelas possibilidades incontáveis de construir um ideal, de materializar as referências, de experimentar o gesto completo entre a Arquitetura e a Arte.

E esse homem, arquiteto, artista, metropolitano, tinha seus pares, seus grandes amigos de alma, Oswlado Bratke, Joaquim Tenreiro, Alberto da Veiga Guignard e Zanine Caldas, entre outros

Para este trabalho, Tenreiro e Guignard foram convocados; personagens que estabeleceram pontes fundamentais para a compreensão da biografia da casa como síntese da obra de Libeskind, o que permite dizer que a arquitetura da casa também é composta pelo que está ao lado ou fora dela, presenças literais e simbólicas.

Ainda ao percorrer a casa, desde o escritório, é possível avistar a sala de jantar, lugar de grande destaque na casa. Espaço em continuidade visual com a sala de estar de pé direito duplo. Desde este ponto tudo se comunica visualmente, como deve ser na escola moderna: espaço fluido, transparente, conectado e sem compartimentação.

E nesse recinto repousava majestoso o conjunto de mesa e cadeiras de Joaquim Tenreiro. A vida da casa depende dos seus objetos, do mobiliário preciso, das obras de arte, dos quadros e esculturas, na mescla precisa entre espaço construído e espaço habitado: espaço fenomenológico. ${ }^{13}$

Deste ponto, é possível contemplar o escritório, na cota mais alta da casa, de onde tudo pode ser observado.

O pé-direito duplo e as aberturas envidraçadas permitem a entrada da luz e o ambiente se multiplica, potencializado, resultado de sequências que se alternam.

13 A fenomenologia, definida inicialmente por Edmund Husserl (1859-1938) como uma investigação sistemática da consciência e seus objetos, é entendida por Norberg-Schulz como um "método" que exige um "retorno às coisas", em oposição às abstrações e construções mentais. (...) Norberg-Schulz identifica o potencial fenomenológico na arquitetura como a capacidade de dar significado ao ambiente mediante a criação de lugares específicos. O teórico introduz a antiga noção romana do genius loci, isto é, a ideia do espírito de um determinado lugar (que estabelece um elo com o sagrado), que cria um "outro" ou um oposto com o qual a humanidade deve defrontar a fim de habitar. Ele interpreta o conceito de habitar como estar em paz num lugar protegido. SCHULZ, Norberg, In: NESBITT, Kate (Org). Uma nova agenda para a arquitetura: antologia teórica (1965-1995). São Paulo: Cosac \& Naify Editora, 2006. p. 443 
O vazio que surge sobre a sala de estar e a vista para a piscina a partir da sala de jantar, metaforicamente representam um recorte do mundo - a janela moderna, o caráter do lugar concebido na medida justa das larguras e alturas, as tonalidades, cores, texturas, e sobretudo, as transparências. Lição já decodificada através de vários outros projetos ensaiados por Libeskind na concepção espacial da casa.

As referências externas e as experiências dos projetos anteriores são também um modo de afirmar seu trabalho e de reconhecê-lo.

A luz constrói espaços, em seu potencial máximo, atravessando as grandes aberturas propostas para o território das Salas de Jantar e de Estar. Quando há ausência da luz natural, a iluminação artificial proposta para a casa também cria atmosferas, ressalta volumes, enfatiza claros e escuros dos diversos ambientes.

O uso dos materiais como pedra e madeira nos espaços de pé direito único, como na Sala de Estar contígua à Lareira e ao Bar ajudam a criar o ambiente mais escuro, aconchegante, quente. Confere o caráter de recolhimento ao redor do fogo, ideia primitiva do lar.

Já nos espaços banhados pela luz natural, o léxico moderno - o cristal dos panos de vidro avantajados e o aço - expressa a transparência buscada na dissolução entre o espaço interior e exterior, no contato das duas instâncias.

A quebra do conceito da parede como um plano contínuo e estrutural é desmontada para se transformar em grandes aberturas, como já afirmado por Mies: "Eu descobri que, Mies escreveu em 1921, "A partir do trabalho com modelos utilizando vidro real, aquilo que importa é o jogo dos reflexos e não o efeito da luz e sombras como ocorrem nos edifícios comuns."

A partir dessa colocação, o que parece importar, para além da transparência em si, são as possibilidades de novos quadros que surgem das múltiplas leituras propostas pela imaterialidade do vidro.

O bar situa-se junto à lareira.

Sua localização abaixo da escada vazada, conforma o ambiente contiguo à sala de estar. $\bigcirc$ bar também exibe marcenaria primorosa de Joaquim Tenreiro e abriga uma bela coleção de esculturas de vários artistas, dentre eles, Bruno Giorgi, Stokinger, também amigos de Libeskind.

Como era usual no período de consagração de nossa arquitetura moderna, a obra de Libeskind contou com contribuições ligadas a iniciativas complementares à arquitetura - caso das lojas de móveis e objetos modernos Ambiente, Artodos, Studio D’Arte Palma (dos arquitetos Giancarlo Palanti e Lina Bo Bardi), e Branco e Preto (dos arquitetos liderados por Miguel For- 
te) - e a colaboração de profissionais renomados, como Roberto Burle Marx,

José Zanine Caldas e Joaquim Tenreiro, em espacial este último, que através do seu mobiliário contribuiu para o renascimento do artesanato de qualidade, preparando o caminho para a fabricação futura de um mobiliário moderno de excelência. Esta natureza estética, entre a arquitetura de Libeskind e o design moderno brasileiro, representado na casa por Joaquim Tenreiro é relevante para este trabalho.

Na lareira o revestimento cerâmico vermelho vitrificado imprime a autoria do arquiteto-artista, sempre à frente das experimentações plástico-matéricas. Aí as peças são desenhadas por Libeskind, uma pesquisa cromática e de composição abstrata dos desenhos presentes no tratamento das superfícies com cores quentes.

A lareira não ocupa um lugar central; porque na casa não há um lugar geometricamente central demarcado, por assim dizer, pois ela se encaixa entre os planos verticais limítrofes entre o bar e a escada, planos espessos tratados com pedras. A lareira e esses planos manifestam seus vínculos com a materialidade explícita, uma certa evocação às casas do passado, uma referência ao ambiente doméstico tradicional, uma ligação da casa com um tempo em contradição com o tempo moderno. ${ }^{14}$

Aí também se dá o retrato do refúgio: o fogo e a bebida em um canto pequeno e protegido, a promover a aproximação das pessoas.

Pode-se dizer que há um efeito produzido no observador pelo correr do olhar e pela experimentação dessa arquitetura, uma questão fundamental da estética, a estética do sublime ${ }^{15}$ e o reconhecimento da arquitetura através do "estar-com-as-coisas".

Em particular, a lareira foi um elemento articulador da organização geométrica da casa bastante importante nos projetos de residência de F. L. Wright. Na Residencia Robie, por exemplo, de 1908-09, a chaminé da lareira maciça da tradição colonial mantinha o edifício fixo, enquanto as horizontais baixas, compulsivamente estendidas, dos espaços amplos irrompiam da caixa tradicional e buscavam alçar voo. "A antiga ordem sólida das coisas - ainda sentida no peso da construção - é fragmentada e seus componentes são reorganizados em padrões mutáveis de um movimento continuo pelo espaço. Dessa maneira a fragmentação, um dos elementos essenciais do significado que encontramos bem no inicio da era moderna, recebeu uma definição formal precisa e foi unida à continuidade na arquitetura da primeira maturidade de Wright, como aconteceu na pintura cubista europeia contemporânea." SCULLY JR., Vincent (1961). Arquitetura Moderna: a arquitetura da democracia. São Paulo: Editora Cosac \& Naify, 2002. p. 41

15 "Na arquitetura do século XX, toda menção ao sublime ou ao belo parece ter sido deliberadamente reprimida por teóricos e projetistas ansiosos por se desvincularem do passado recente. A "ruptura radical" com a história da disciplina que o modernismo almejava impunha uma mudança nos princípios adotados pela teoria estética. A retorica anterior foi suplantada por um debate de ideias acerca da necessidade de fazer uma tábula rasa da estética e de adotar princípios científicos no projeto arquitetônico, a ênfase positivista na racionalidade." In: NESBITT, 2002. p. 33-34 
Esse era o lugar mais acolhedor da casa, onde Libeskind costumava convidar para contar sobre as suas experiências com a arte e com a arquitetura. Um refúgio cercado de referências e obras de arte que foram presentadas ao longo de sua vida pelos amigos. O escritório e o bar eram seus lugares de preferência na casa, seguidos pelo seu ateliê.

Há uma espécie de negociação entre os materiais explicitamente reconhecidos como pertencentes ao léxico moderno, próprios da época industrial como o aço, o vidro, o concreto, e os materiais como pedras, madeira, ladrilhos, todos capazes de estabelecer um diálogo entre si. Enquanto a construção moderna - vidro, cobertura plana e regularidade modular contribuem para gerenciar o expediente espacial continuo e horizontal, o gesto de fundar e delimitar a casa recorre aos materiais como a pedra, um indício de retorno à condição ao ponto de origem, à memória.

E esses lugares da arquitetura estavam diretamente conectados com o caráter de cada espaço, cada objeto atuando como coadjuvante do teor da vida, como que se a casa guardasse em cada móvel, cada textura, cada obra de arte um sentir com os olhos e com a pele: a presença constante de Libeskind.

A partir da lareira em direção às duas salas de estar a luz invade o ambiente através de portas deslizantes que proporcionam a fusão entre a paisagem externa com o interior da casa. O que se vê através do conjunto de fenestrações é um jardim externo, um piso seco e a piscina.

O vidro, adotado por Libeskind para abrir completamente a casa para a paisagem exterior, enquadra sua própria criação, paisagem construída, aquilo que ele elegeu para ser visto.

A piscina faz parte de um conjunto composto por um muro baixo, revestido de cerâmica com desenhos do arquiteto-artista em companhia de uma escultura de Vitor Brecheret. Segundo Sandra Brecheret Pellegrini, filha do escultor, a obra é da década de 1920, época em que seu pai estudava na Europa.

"É uma escultura de granito, bem resistente. Não tem nome porque papai não costumava batizar suas obras. Mas as pessoas costumam chamá-la de "Banho de Sol", explica. Ela conta que seu primeiro proprietário a comprou para decorar a frente de sua casa. (Libeskind revelou que esse proprietário era seu sogro, que adquiriu a peça para colocá-la no jardim de sua casa, no Jardim Europa, casa na qual o jovem casal Libeskind recém-casado habitou ainda nos finais da década de 1950, antes do término das obras da Casa do Pacaembu). Depois, ela foi adquirida pelo David Libeskind, um dos mais importantes arquitetos brasileiros. Ele a vendeu para o Edemar Cid Ferreira no final dos anos 1980 ou no começo dos anos 1990." 
Descendo as escadas a partir do nível da piscina e terraço externo (mes-

ma cota das salas de estar) é possível acessar o ateliê. De um ponto de vista mais simbólico, paralelo em cota negativa com a piscina, este é o lugar de isolamento para o arquiteto-artista, para um recinto da criação livre, da expressão necessária e vital. Fusão de mundos, de ideias e de expressões, território criativo e singular do homem moderno. Lá, Libeskind ainda tentava bravamente, a despeito da sua condição de saúde, realizar inúmeras tentativas de retomar a atividade de artista plástico. ${ }^{16}$

Há nesses processos experimentais com as telas, tintas e materiais um campo de provas para a sua arquitetura, que revela uma sensível evolução desde a casinha de Belo Horizonte, ainda na década de 1940 (seu primeiro projeto construído) até a afirmação de uma linguagem realmente própria, ideia que apoia a seleção das quatro casas - conjunto construído na década de 1950 selecionadas em órbita com a residência do arquiteto, a casa do Pacaembu, de 1961. Nessas casas os planos tratados com elementos materiais revelavam a distribuição sensível dessas experimentações pelos espaços, por sua vez, categorizados através desses tratamentos.

Nos últimos anos de vida, por volta de 2012, Libeskind voltou a desenhar através de uma técnica de grafismo intenso, que tirou partido das suas limitações motoras, os últimos registros que unem os dois pontos da sua trajetória - do início das suas experimentações como artista plástico, ainda na infância, e da fase final da sua vida, ambas através da mesma linguagem: a representação figurativa.

Em seu ateliê, uma curiosidade: um visor em forma de escotilha que permite olhar para a água da piscina, criação do arquiteto para poder mirar seus fiIhos nadando enquanto pintava. Essa janela para a água reconectava Libeskind à vida real, à família, ao movimento do cotidiano correndo lá fora, mesmo que através de transparências sobrepostas.

Subindo de volta à "cota positiva" da casa, há um elemento que chama a atenção. A parede de pedras que abrigava os quadros da sala de estar - pinacoteca particular de Libeskind -e que hospedou as telas de célebres artistas modernos brasileiros: Anita Malfatti, Portinari, Rebolo, Di Prete, Manabu Mabe, ${ }^{17}$ entre outros.

Segundo Tassinari, "a variedade de movimentos artísticos foi decisiva para a arte moderna. Concorrentes, importava menos a convergência entre

16 Libeskind foi acometido pela doença de mal de Parkinson, aproximadamente no inicio dos anos 1990 e lutou praticamente durante 20 anos contra a enfermidade.

17 A 5a. Bienal Internacional de São Paulo, realizada pelo crítico e historiador da arte Lourival Gomes Machado em 1959, mostrou e premiou um grande número de artistas informais, tanto 
eles que as diferenças sobre o presente e o futuro de uma arte, ainda incerta, que posições antagônicas disputavam. Uma nova arte inventando-se, e sempre a inventar, só encontrava, quando encontrava, denominador comum na oposição à tradição."18

A coleção de obras de arte de Libeskind compreende peças obtidas ao longo de sua vida, objetos que muitas vezes foram trocados com os amigos artistas e fazem parte da tradição de uma época. A idealização do espaço da casa se completa com telas e esculturas, peças do mobiliários que formam um conjunto indissociável, reflexo da linguagem moderna e que serão analisados nos capítulos seguintes.

Não obstante sua relação espacial com a casa, é possível observar que a coleção imprimia sobre a parede de pedras, um registro histórico: a narrativa pessoal de um percurso e a completa liberdade expressiva que a Arte mantem com o seu suporte estrutural, o plano vertical de pedra. "Há encontro e conexão entre o suporte e as telas expostas, para designar os vários conjuntos em que a arte e a arquitetura são justapostas e/ou combinadas a arquitetura por vezes ocupando (o que antes se considerava) o lugar da arte".19

Libeskind lembrava dos amigos artistas que trocavam suas obras de arte por projetos de arquitetura. Assim fora com Mabe, com Di Prete, com Tenreiro. Um intercâmbio intenso, colaboração de universos.

Libeskind se recordava com muito carinho de Danilo Di Prete, o amigo artista que o levou para participar das montagens das Bienais de São Paulo e o possibilitou travar contato com as obras abstratas, nos anos 1960.

Ele adquiriu um quadro de Danilo Di Prete, acerca de 1957 e acertou o pagamento da tela em parcelas. Quando foi levar o referido pagamento de

internacionais como brasileiros. A premiação de três nomes de relevo do cenário informalista local - Yolanda Mohalyi (aquisição pelo Museu de Arte Moderna de Sao Paulo), Arthur Luiz Piza (melhor gravador nacional) e Manabu Mabe (melhor pintor nacional) - pode ser considerada um marco significativo da penetração da abstração informal no pais, bem como o premio de pintura internacional entregue ao espanhol Modesto Cuixart. De acordo com a estudiosa Maria Alice Milliet, a premiação de Mabe como melhor pintor nacional ameaçou a posição vanguardista assumida pelo romantismo geométrico no período. Na época, o critico Mario Pedrosa se referiu ao evento como uma "ofensiva tachista e informal", pois acreditava que a abstração geométrica se configurava como resistência ao gosto artístico internacional. Segundo o poeta e critico Ferreira Gullar, que poucos meses antes da Bienal havia assinado o manifesto neoconcreto, desse modo afirmando sua adesão às vertentes construtivas, essa edição foi tão impactante quanto a inaugural. Para ele, a exposição de 1959 representou uma importação das questões da arte abstrata internacional do período, em grande parte, informalista. Para Pedrosa e Gullar, o informalismo tratava-se, portanto, de uma necessidade de alinhamento da arte brasileira com a internacional, um sintoma de submissão cultural. 
uma das prestações a galeria havia fechado. Na tentativa de honrar com a dí-

vida Libeskind conheceu o artista e uma amizade nasceu. "Nessa época, conta Libeskind, Di Prete fazia experimentações com tintas coloridas sobre os guarda-chuvas dos transeuntes, lá embaixo, na rua, a partir da janela do alto de seu apartamento". ${ }^{20}$ Uma diversão que aos poucos reconectou Libeskind à liberdade da produção artística, agora sem a tutela de outrora.

Dos anos de formação artística na escolinha do Parque, em Belo Horizonte, sob a orientação de Alberto da Veiga Guignard, nos anos 1940, até seu encontro com Danilo Di Prete, [pelo menos uma década mais tarde e já em São Paulo] homem de confiança de Cicilio Matarazzo, para pesquisar a Bienal de Veneza e trazer na bagagem a formula para as Bienais paulistanas, Libeskind jamais parou de pintar. Mas a sua experiência artística se transformou e essa mudança se deve à sua experiência na Metrópole. São Paulo teceu o modo de fazer e como Libeskind se estabeleceu enquanto arquiteto-artista moderno.

A convivência no Instituto de Arquitetos do Brasil em São Paulo foi fundamental para que suas relações e a teia de conexões e contatos se estabelecesse a partir da sua chegada na cidade. Libeskind foi responsável pela 1 Mostra Individual de Guignard em São Paulo, na sede do Instituto. O apogeu da pintura como paradigma de toda a arte modernista reafirma esse intercâmbio entre Arquitetura e Arte e ainda que a primeira como suporte da segunda.

Quando chegou em São Paulo, com duas cartas de recomendação de Sylvio de Vasconcelos (seu professor na Escola de Arquitetura, em Minas Gerais), uma para Lourival Gomes Machado e outra para Luís Saia, Libeskind se hospedou numa pequena pensão ao lado do IAB. Ele costumava frequentar as reuniões do "clubinho", como era chamado carinhosamente o Instituto. Lá, ainda muito jovem, e sem um escritório fixo, desenvolveu os primeiros croquis para o projeto do Conjunto Nacional.

Os arquitetos paulistas, segundo ele, se dirigiam para os seus escritórios pela manhã, se reuniam para o almoço e em época de Bienal, passavam as tardes visitando as mostras, que apresentavam um caráter multidisciplinar nas suas primeiras edições.

Essas visitas, que Libeskind passou a realizar ao lado de Di Prete nos períodos de montagens das Bienais, o fez ter contato com a arte abstrata, mais precisamente com a obra de Alberto Burri, artista que influenciou significativamente a sua produção, objeto de maior investigação neste trabalho.

No percurso pela casa, estão colocadas lado a lado as categorias de tec- 
tônica e estereotomia observadas por Gottfried Semper e revistas por Kenneth Frampton. ${ }^{21}$

Compreendidas, de maneira geral (considerando o segundo caso descrito por Frampton) - a tectônica, como aquilo que se relaciona com a tensão, com a leveza, com a imaterialidade e com a luz, e nesse sentido as transparências são na casa exemplares deste espaço não construído, mais aberto e leve. No caso, a estereotomia representa o muro sólido, telúrico, que trabalha as perfurações ou subtrações da matéria.

Pode-se também, segundo o autor, falar em expressão tectônica para definir "um domínio da criação do espírito puro cujo objetivo é provocar emoções plásticas de acordo com a expressão do inventor."

Percebe-se então na casa uma divisão, através de uma linha abstrata que parte a casa em dois territórios, cada qual dessas partes ligadas às categorias elencadas acima.

A porção leste da casa, está demarcada pelo território dos muros e da pedra, daquilo que mais a conecta à ideia da terra, o que se funde com o solo. A porção oeste, representa a luz, a transparência, de certa forma, a imaterialidade.

Na casa vazia, por exemplo, é possível observar a luz que banha os espaços internos sem obstáculos. Sem tapetes ou cortinas, sofás, luminárias ou vasos com plantas ou quadros nas paredes, tudo se converte em puro plano vertical ou horizontal, na literal expressão da sua materialidade.

Os objetos desaparecidos proporcionam a leitura pura das ideias de concepção, juntamente aos elementos construtivo-espaciais da casa, que nesse caso, ressurgem sem distrações. O lugar, outrora povoado e vivo se transforma em outra coisa. O lugar, agora distante dos seus objetos, se torna a expressão pura da arquitetura.

Esse conjunto indissociável possibilita reconhecer um caráter de um tempo em movimento: a casa, os elementos construtivos, os materiais e os

21 Frampton em Studies in tectonic culture, de 1955, analisa a tectônica na obra de Frank Lloyd Wright, August Perret, Mies van der Rohe, Louis Kahn, Jörn Utzon e Carlos Scarpa. Num primeiro sentido, a palavra tectônica descreve geralmente a ideia da "construção considerada de modo artístico". Num segundo sentido, o termo se refere principalmente à ossatura leve tencionada (light tensile skeleton frame), um sentido derivado da própria etimologia do termo tectônica. Num terceiro sentido, mais genérico, o termo é utilizado para designar toda forma construída, incluindo assim a categoria do "estereotômico" que remete à ideia de peso, da compressão de uma alvenaria portante. Num quarto caso, tectônica é utilizada para descrever o modo de trabalhar e de montar um material, como nas expressões 'tectônica do metal' ou 'tectônica da madeira'. Enfim, num último caso, Frampton faz uso do termo 'atectônico', uma noção tomada de empréstimo a Edward Sekler, e que faz referência a um modo de expressão no qual a lógica estrutural de uma obra é escondida ou suprimida. 
seus objetos sobrepostos, superpostos, justapostos e finalmente desmonta-

dos e desaparecidos, momento em que a leitura se descola da obrigatoriedade das presenças.

O arco temporal permite, ao longo de mais de cinco décadas de existência da casa, identificar as permanências e transitoriedades. A casa habitada, preenchida, ou o vazio qualificado e seus lugares, e os fenômenos todos interligados a partir do seu esvaziamento, quando a transparência é total e a presença, agora, é uma silenciosa ausência.

Libeskind, o criador, se foi e os seus objetos também, mas a casa permanece e tudo o que nela se fixou como ideia e registro expressivo e simbólico permanece.

A casa vazia permite olhar através e além do fato real. Como se "o historiador pudesse ser tal com a condição de que o objeto do seu pensamento seja algo histórico e não apenas no sentido daquilo que já sucedeu, mas no sentido do acontecido historicamente, realizado para a história."22

Os volumes, os planos verticais e horizontais, as relações das variadas alturas dos pés-direitos se apresentam livres de quaisquer interferências. Mas a casa vazia reclama as presenças, a forma de se esparramar através dela e ocupar os seus lugares. A casa vazia tem o cheiro do nada. ${ }^{23}$ Mas pode tudo. Onde, agora, não há vida, ainda há arquitetura.

A discussão proposta por Xavier MONTEYS - colaborador na Revista Quaderns d'Arquitectura i Urbanisme na seção "Domèstica" - que avança no entendimento da relação entre invólucro, vazio, objetos e usuário para determinação do grau de "domesticidade" presente em um lugar, propõe reposicionar o papel da arquitetura na definição do que é a casa. Neste sentido, a arquitetura não é protagonista da cena; o autor fala sobre a falta de protagonismo necessário à arquitetura para protagonismo da vida cotidiana. Nos exemplos citados no texto, não importa a configuração material externa do habitáculo. O involucro é apenas suporte para conter coisas em seu interior. E, do mesmo modo que o habitáculo desocupado é apenas uma caixa vazia, o habitáculo preenchido com objetos é mais do que um depósito de móveis. É assim que o autor chega ao conceito de "aura vital" que emana do espaço, a partir do conjunto dos objetos no espaço mais a presença do usuário. No livro Casa Collage - un ensayo sobre la arquitectura de la casa (2001), o autor explora o assunto dos objetos da casa enquanto resquício da presença humana, ao discutir experiências nas quais os objetos da casa são todos removidos para a rua, ou nas quais a mesma casa é representada cheia ou vazia, alterando significativamente nossa percepção do que efetivamente determina o espaço doméstico, de modo a incluir o rastro do usuário em nossa percepção.

O autor mostra interesse pelo conjunto de objetos e pelas pessoas que ocupam os espaços da casa, buscando compreendê-la como a conjunção do espaço da casa com "as pessoas que habitam e os objetos que guarda". Ao incluir objetos e moradores e ampliar o entendimento daquilo que determina o grau de domesticidade da casa, o autor aposta no uso como o elemento chave da discussão sobre o espaço, e estimula a revisão do uso com o mínimo de operações arquitetônicas a partir da revisão de conceitos arraigados tanto na ação de projeto como no hábito de morar. 
No interior desse vazio latente e instável - quando as relações outrora impressas pelo arquiteto-habitante são reconstruídas no retorno metafórico ao tempo da concepção da obra - o rigor da linha e das geometrias, as relações planares e volumétricas se colocam ao dispor do observador, na escala nua.

A casa permanece viva em todos estes tempos da sua existência, somando a ela a consistência e a síntese, o que se fixou como o legado da obra de Libeskind.

Para L. Kahn, "Recorrendo à matéria, que é o fazer, o fazer ser, esta criação de presenças, é o elemento que introduz o mensurável na obra. Até que não entre em ação, tudo é essencial e coerentemente incomensurável. (...) Uma vez pintado um quadro, e apenas neste momento, podemos dizer: "Não gosto de roxo", ou bem, "prefiro as telas pequenas". Só então a existência revela ser o que o pensamento queria ser ou poderia nos oferecer. E o pensamento, por sua vez, revela possuir existência, mas não presença."

Enquanto vazia é possível realizar a leitura da massa da casa de Libeskind, a partir da materialidade impressa nos volumes e formas, distinguíveis pelos elementos construídos, sólidos - a gravidade da matéria; há nessa condição o desejo de desmaterializá-la e fazer emergir a transparência própria do vazio e da interpenetração dos espaços internos da casa, da diluição dos seus limites, num jogo de presenças e ausências.

"Essa dupla tensão entre materialidade e desmaterialização é recorrente em toda a arte e arquitetura do século XX."24

A ideia da transparência "literal", em que a estrutura e o espaço são revelados por meio do vidro e de aberturas reais, pode ser contraposta pela ideia de uma transparência "fenomenal", ou fenomênica, em que a estrutura e o espaço são tornados indeterminados mediante superfícies e peles "cubistas" que se interpenetram sem perder suas qualidades óticas. Isso seria fazer aparecer na arquitetura o valor da superfície, tão importante quanto a articulação do

24 Já no final da década de 1920, a clara exposição da estrutura e do espaço era considerado o critério essencial dos projetos modernistas. Para Sigfried Giedion essa transparência se baseava nas tecnologias de vidro e aço e concreto armado há muito estabelecidas, mas para que fosse valorizada como tal foi preciso esperar uma mudança no "modo de vida" ou na Lebesform no século XX, bem como o incentivo de pesquisas análogas em outras artes (era assim, por exemplo, que ele compreendia a motivação principal que estava por trás da pintura cubista). No mesmo período, Laszló Moholy-Nagy concebia transparência como uma operação transformadora presente em todas as artes visuais. Menos preocupado com a estrutura e o espaço do que com a luz, Moholy instalou a arquitetura em específico a integrar as diferentes transparências promovidas por meios como a fotografia e o cinema. Ele considerava que essa integração era necessária para a "nova visão" da cultura modernista no sentido amplo. In FOSTER, 2015. p. 129. 
espaço, e uma leitura das peles, dos tratamentos, dos materiais, tão relevante

quanto uma compreensão de sua estrutura. ${ }^{25}$

Segundo Rowe, citado acima, transparência, tempo-espaço, simultaneidade, interpenetração, superposição, ambivalência, na literatura da arquitetura contemporânea são palavras comumente utilizadas como sinônimos.

De acordo com a definição, a qualidade ou estado de ser transparente é, em ambos os casos uma condição material - permeável à luz e ao ar - e o resultado de um imperativo intelectual daquilo que é facilmente detectado, perfeitamente evidente e livre de dissimulação.

“(..) Transparência significa uma percepção simultânea de diferentes localizações espaciais (...) a transparência deixa de ser aquilo que é perfeitamente claro e se torna aquilo que é claramente ambíguo."

Transparência é uma qualidade inerente da substância, como no plano envidraçado; ou pode ser uma qualidade inerente de organização. Pode-se assim se distinguir entre a transparência literal e a transparência fenomênica, e, ainda localizar a discussão no campo da fusão entre fatores temporais e espaciais.

Pode-se, na casa de Libeskind estabelecer a leitura dessas categorias de transparências colocadas por Rowe. Percebe-se que em toda a casa existe uma espécie de contradição das dimensões espaciais que, segundo Kepes ${ }^{26}$ tomava como característica da transparência. Há uma continua dialética entre o fato e suas implicações. "A realidade do espaço profundo se opõe constantemente à inferência do espaço superficial, e, graças à tensão resultante, nos obriga a efetuar sempre novas leituras."

Surgem transparências e sobreposições no que concerne à leitura dos volumes internos em termos de planos verticais - toda e qualquer presença que delimita e marca um ambiente ou o divide em relação ao espaço vizinho - e planos horizontais - que sugerem a continuidade, a patamarização, o acerto pp. 46 [ed. Bras.: "Transparência: Literal e Fenomenal", trad. Leila Vasconcellos, Gávea, n. 2, pp. 33-50, 1985]

"A medida que o observador distingue entre todos os planos resultantes, vai tomando consciência da oposição entre certas áreas da pintura luminosa e outras, de coloração mais densa. Também pode distinguir entre certos planos aos quais pode atribuir uma natureza física aliada ao do celuloide, por exemplo, outros aos quais a essência é semi-opaca, e a ainda outras áreas de substancia totalmente oposta à transmissão de luz. E pode descobrir que todos esses planos, translúcidos e opacos, independente do seu contudo representacional, se encontram implicados na manifestação que György Kepes definia como transparência." In KEPES, György. Language of vision. Chicago: Paul Theobald, 1944. Reissued: New York: Dover Publications, 1995. 
com o lugar, mesmo que tratados com materiais de naturezas distintas: translúcidos, opacos ou transparentes.

O enquadramento da vista a partir da sala de jantar, por exemplo, descortina camadas de transparências em justaposição à volumetria suspensa do escritório. Em primeiro plano o guarda-corpo em madeira propõe uma transparência filtrada, que contrapõe sua horizontalidade ao ritmo impresso pela repetição dos seus elementos verticais em madeira. Essa mesma ideia se repete no desenho da caixilharia das aberturas que reforçam a verticalidade em oposição aos requadros horizontais que formam seu desenho.

Aparece um espaço intermediário, um vazio, um segundo plano subsequente ou camada de transparência que permite a percepção de cada plano unitário ou volume singular dessa imagem. Esse espaço, ocupado originalmente pela sala de estar e agora completamente vazio reforça a gravidade implícita do bloco maciço do escritório, que completa junto à fachada externa da casa a ideia do volume que penetra nesse vazio.

A ideia de transparência literal proporcionada pelas aberturas envidraçadas provoca leituras múltiplas pela qualidade implícita do material - o vidro que além de permitir a vista da área externa, imprime reflexos que redesenham simetricamente o próprio desenho da caixilharia.

Esse segmento de planos com categorias de transparências distintas é reforçado pela sequência de pilares que apoiam o volume que abriga a área intima da casa. Em fileira, esses apoios ajudam a construir a perspectiva e estimulam a compreensão da dicotomia entre a leveza do vidro e o peso do volume maciço. Seria aqui o encontro entre a tectônica e o estereotômico?

O plano final que arremata essa sequência, mais uma vez reforça a horizontalidade que se faz presente no primeiro plano de madeira (guarda-corpo da sala de jantar), ou, ainda, externamente à casa, no seu portão de vergalhões de ferro e as vigas metálicas sobre a garagem.

Ainda há relações que se estabelecem nos planos horizontais, de piso e teto, também gerando transparências e distintas leituras na composição. Destacam-se o piso de granito da sala de jantar, que reflete o guarda-corpo e os reflexos gerados na água da piscina, plano de transparência da água, que assume o espelhamento da paisagem circundante, reverberando em continuidade a própria casa, um "moto perpetuo".

Ao reconhecer o plano físico do vidro e das massas construídas e esse plano imaginário (mas não menos real) que se instala entre eles, é possível compreender que aqui a transparência não se obtém necessariamente por meio de uma janela, mas através da consciência dos conceitos primários que se "interpenetram sem a destruição ótica dos outros". 
Cada um dos planos está individualmente incompleto e até fragmen-

tado; entretanto, há uma espécie de estratificação vertical do espaço interior, uma sucessão de espaços que se estendem e se completam, um após o outro, gerando, segundo Kepes, a "transparência fenomênica".

Ao olhar, por exemplo, a imagem da mesa com tampo de vidro da sala de jantar (peça desenhada por Joaquim Tenreiro) que ocupava a casa enquanto habitada, numa situação de luz do dia é possível reforçar a leitura da transparência literal, criando nesta situação, mais leituras reflexivas, como uma impressão dos elementos da arquitetura no objeto do uso cotidiano. As cadeiras, com assento e encosto em palhinha também permitem a passagem de luz, que naturalmente é filtrada de uma outra forma de modo que as materialidades da arquitetura e do mobiliário criam novas camadas de transparências e infinitas possibilidades de arranjos através da articulação de frontalidades, sombras e espacialidades abstratas.

A imagem da casa refletida na água da piscina, impressa como num celuloide, marca o tempo de permanência da luz na água, espécie de ativação do tempo em sua imanência, uma vez que em todo o projeto da casa há a ativação da condição horizontal, com reflexos na continuidade e fluidez espacial, desvinculando-se com a ideia de luz zenital, de vínculo vertical.

Essas reflexões luminosas nos pisos e tetos também propõe um certo equilíbrio óptico, com equivalências de tonalidades num processo de desmaterialização da luz.

A partir da Sala de Jantar, agora tomada como exemplo, a vista para a escada e para o bar prescinde do material de transparência literal - o vidro. Desta forma, a construção espacial a partir das sobreposições imprime a transparência fenomênica colocada por Kepes, gerando um espaço cubista, onde os objetos e figura-fundo possibilitam o olhar que organiza os elementos em perspectivas aleatórias. Aqui os materiais opacos bloqueiam o "ver através" ou os reflexos transparentes; entretanto, ao espaço é conferida certa tensão entre arquitetura, mobiliário e obra de arte. As esculturas representam os elementos instáveis nessa cena, repousadas sobre bases descoladas do fundo - planos verticais brancos e neutros, ou orgânicos, coloridos, rugosos, que recebem as telas. A tensão se amplia com as linhas diagonais - guarda corpo e corrimão da escada.

Algumas obras de arte e peças do mobiliário convivem à revelia de uma solução em continuidade com os elementos da arquitetura e dessa forma ganham uma posição bastante particular nos arranjos organizados por Libeskind enquanto habitava a casa. Sobretudo as esculturas, vistas a partir de certos ângulos, pareciam flutuar entre os outros elementos da composição. Essas peças, 
aliás, em conjunto com as telas, estavam em contínua mudança de posição, algo que se revela pela observação das imagens do interior da casa em momentos diversos da sua existência. De um ponto de vista metafórico, o interior da casa vivia num regime de movimento envolto em si mesmo.

A noção de limite difuso que se estabelece a partir do contato-fusão entre os elementos físicos ou imateriais, permite a construção de novos lugares, que por sua vez também se estabelecem pelo arranjo das camadas e dos planos de acomodação da casa.

A partir do raciocínio colocado, o programa também se dilui, uma vez que as categorias a priori designadas para cada ambiente destinados à determinada função poderiam adquirir novas possibilidades de existência. $\bigcirc$ vazio se torna o lugar das possibilidades, dos eventos reconfigurados.

A leitura da casa em tempos distintos permite confrontar os aspectos espaciais enquanto entidade física, programada para desempenho de funções e espaço enquanto experiência espacial, este último, potencializado pelo vazio absoluto da casa, isento das interferências das coisas e dos objetos do uso cotidiano 27 .

"A arquitetura extrai seu significado das circunstâncias de sua criação; e isso pressupõe que o que lhe é exterior - o que se pode denominar imprecisamente de seu conjunto de funções - tem uma importância vital"28

A importância do significado da arquitetura e do conceito de lugar enfatizam a especificidade da experiência espacial, "um modo de resistir ao relativismo das teorias modernas da história pelo engajamento do corpo e sua capacidade de verificar as qualidades de um sitio."29 A casa é na totalidade constituída de coisas concretas que possui substância material, forma, textura, cor. Juntas essas coisas determinam uma "qualidade ambiental" que é a essên-

27 Luis Antonio Jorge, ao analisar a Casa Poli, dos arquitetos Pezo e Sofia Von Ellrichshausen, no Chile, ressalta: "A lição de habitar, ao falar da necessidade de se libertar de todas as coisas (...), de se despir daquilo que se acumulou e que, em certa medida, nos define. As coisas saem de cena nesta verdadeira "arquitetura de guardar" e ao nos abandonar, somos nós que nos despimos, sem a nossa biografia encarnada nas coisas familiares. Operação ardilosa para intensificar a tensão fundamental, o sentido mais profundo do confronto entre a mente geométrica - portanto abstrata e atemporal - $e$ a carne do mundo sensual no seu transcorrer temporal". In: JORGE, Luís A. A arquitetura é um acerto de contas com o lugar. Sistematização crítica da produção acadêmica. São Paulo: FAUUSP, 2016. (Tese de Livre Docência). 
cia do lugar, entretanto, a presença concreta também é vivida como um con-

junto de qualidades, ou, em geral, como um "temperamento" ou "caráter", que forma o pano de fundo dos atos e acontecimentos.

As transparências, materializações e desmaterializações no confronto entre a casa habitada e a casa vazia, sugerem territórios da incerteza, da contaminação e das transformações em curso, pois, se de um lado temos a capacidade de realizar uma possível leitura da casa, guiada por seu autor-morador, percebendo os objetos que fazem sentido à construção do caráter espacial, da atmosfera e dos princípios que nortearam a produção de Libeskind, por outro lado é possível realizar um exercício de esvaziamento das coisas ou da experiência com as coisas então inexistentes, de modo que as relações agora são outras, um território diverso que permite a construção de uma noção temporal diversa, "na medida em que o passado se reúne no presente, e em que o conjunto de experiência assim reunida se encontre no espírito, o presente adquire sua profundidade temporal perdendo a acidez e o fio da navalha da sua imediatez. É então (quando) se poderá dizer que o tempo se interioriza ou se torna transparente". ${ }^{30}$

A casa vazia é, de certa forma, um texto aberto, instável, povoada de novas possibilidades, mas que contém as impressões da sua vida permanentes.

Dá-se, como objetivo deste trabalho contribuir para a construção de uma crítica que suplanta a inicial pesquisa apoiada no reconhecimento, organização e compilação sobre fontes primárias, mas que demonstra que "hoje não parece necessário demonstrar a pertinência da análise historiográfica como instrumento adequado para a compreensão do processo de construção da hegemonia da arquitetura moderna de raiz corbusiana no Brasil."31

E nesse sentido, "sabe-se que um trabalho de arquitetura deixa pelo menos três tipos de vestígio documental direto, que os historiadores chamariam primário. (...) Especialmente em um período marcado por forte voluntarismo, os arquitetos justificam seus projetos por meio de texto, teóricos ou de combate, de desenhos e obras. A intervenção de um quarto nível documental, o da crítica ou da historiografia, é mais complexa do que indicaria chamá-lo simples-

31 Ainda se manifesta o ranço anti-intelectual, de que uma certa historiografia não está isenta de culpa, que vê no trabalho do historiador de arquitetura uma ação referenciada nos textos mais que na leitura de projetos ou, por outro lado, uma descrição dos fatores e condicionantes externos à ação projetual, mais que uma pergunta sobre sua lógica interna e seu valor como ação cultural. In: MARTINS, Carlos Alberto Ferreira. Arquitetura e Estado no Brasil: elementos para uma discussão da constituição do discurso moderno no Brasil. Dissertação de mestrado. São Paulo, FFLCH USP, 1988. 
mente de secundário. A análise das relações entre experiência artística e experiência verbal, superadas as visões de sua mútua irredutibilidade, leva a uma transformação da percepção do trabalho crítico e/ou histórico que reconhece "a crítica como uma participação ativa fundamental não só na propagação, mas também na geração da cultura arquitetônica."32

Na arquitetura de Libeskind é possível ver depuração, transparência, precisão e rigor geométrico na construção do espaço, no acerto dos planos, no equilíbrio entre alturas e larguras. E nessa mesma arquitetura comparece a pintura, no uso da cor, da matéria, da experiência plástica impregnada nos elementos de composição das superfícies. Da mesma forma que na casa do arquiteto as presenças de Tenreiro e de Guignard são partes integrantes e constituintes e, portanto, os componentes não são adicionados (porque nessa arquitetura algo esteja a faltar), mas todos os elementos nascem com ela, são fundamentais na concepção dos projetos porque são expressão e manifestação da existência, que é a vida do arquiteto, fato que torna a casa um testemunho, uma biografia da qual Libeskind não se desprendeu, em tempo algum, das lições de pintura (nem da figurativa que operou no desenho o rigor gráfico e nem da abstrata que permitiu viver o drama da matéria), mas estas são as estruturas da sua vida-arte-arquitetura. 



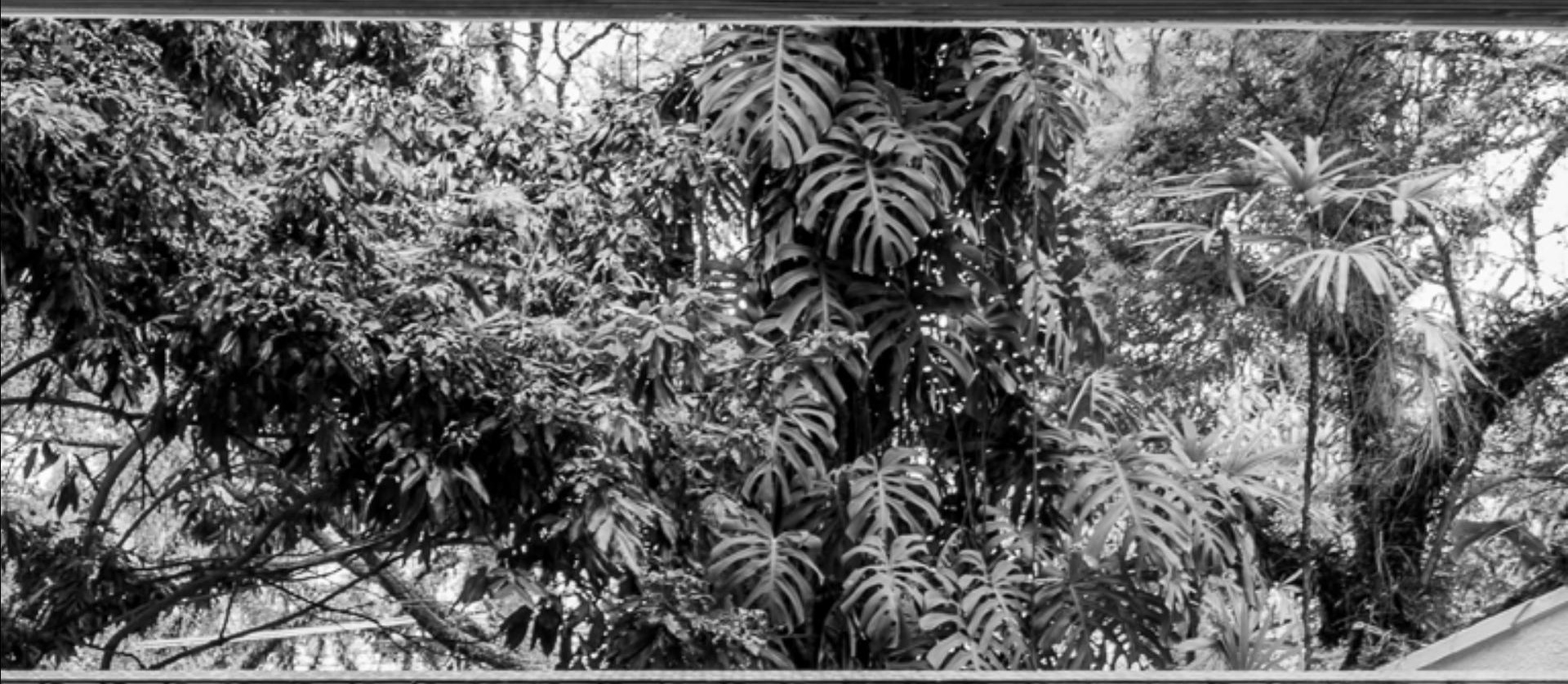

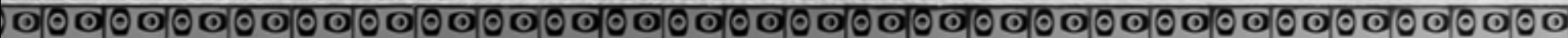

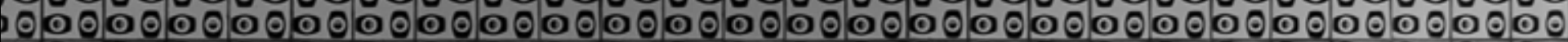

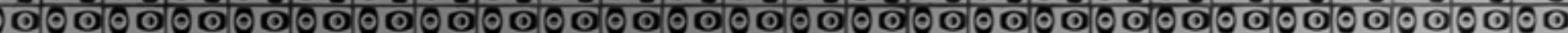

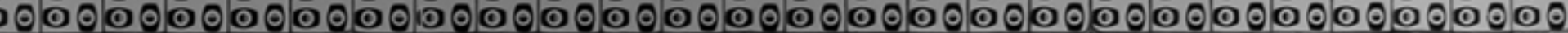

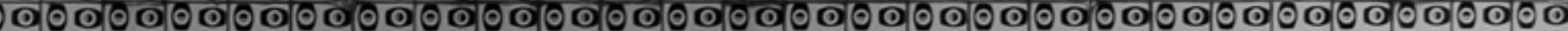

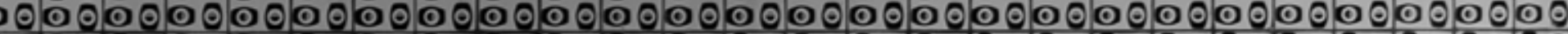

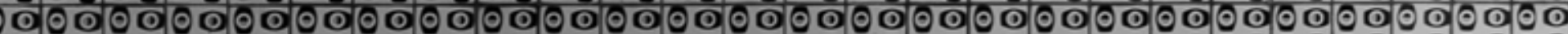

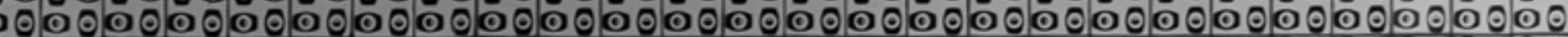

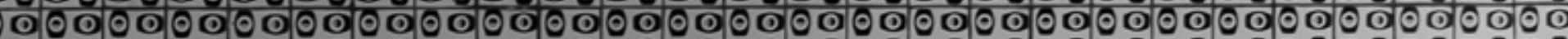

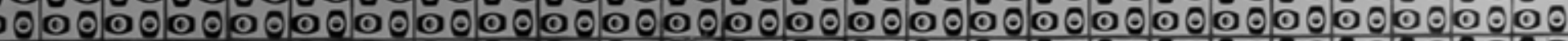

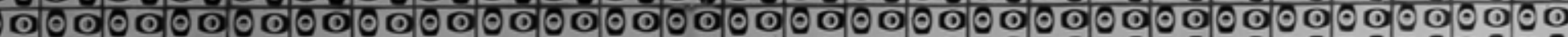

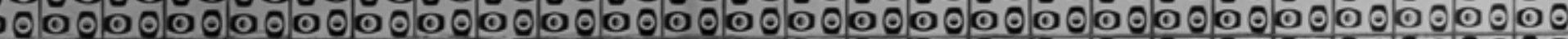

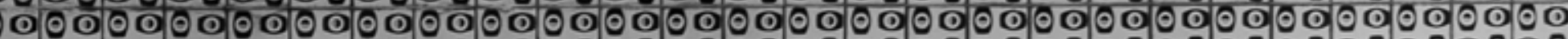

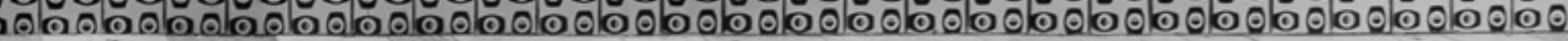



SEGUNDO ATO: ARQUITETURA VIVIDA 

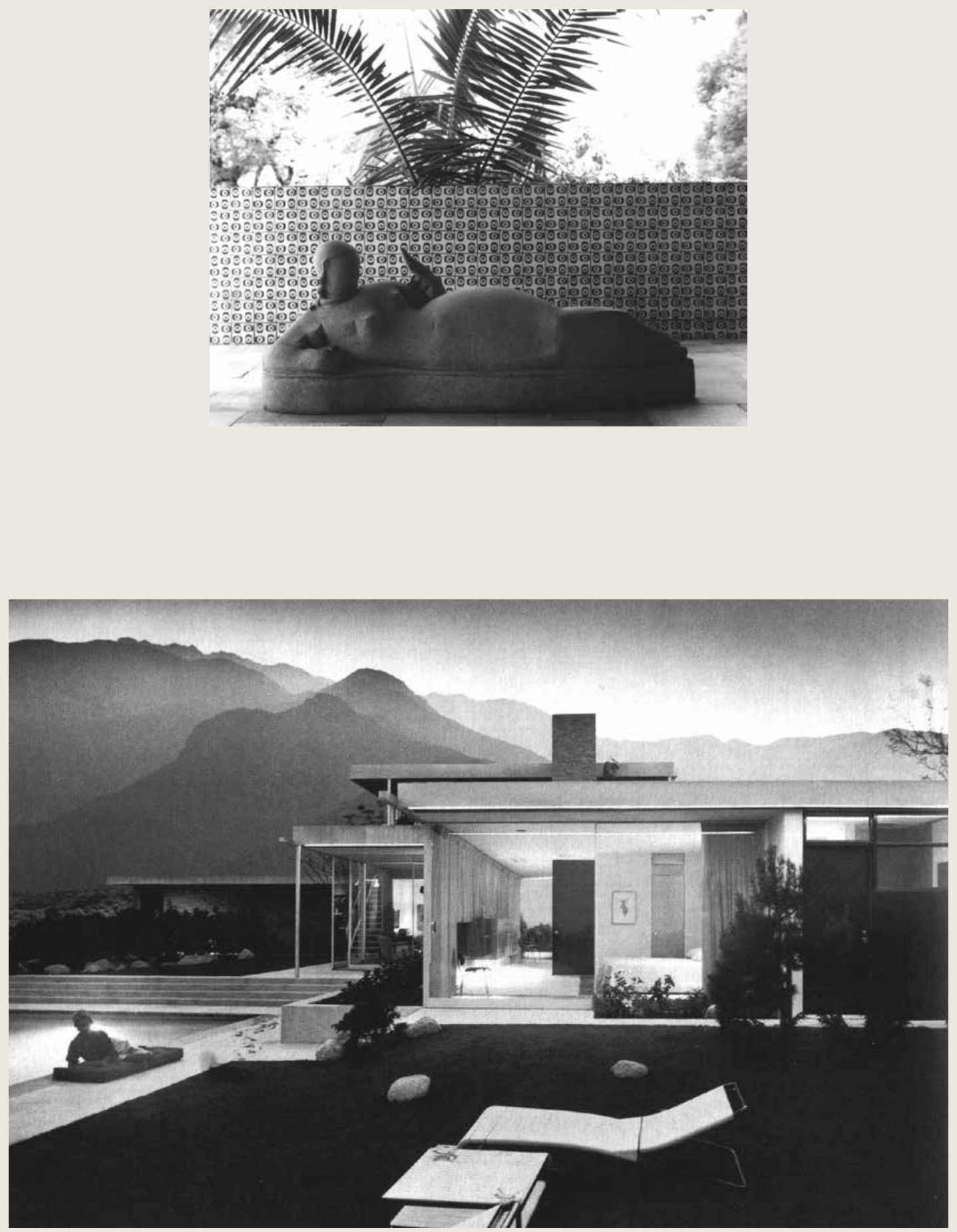


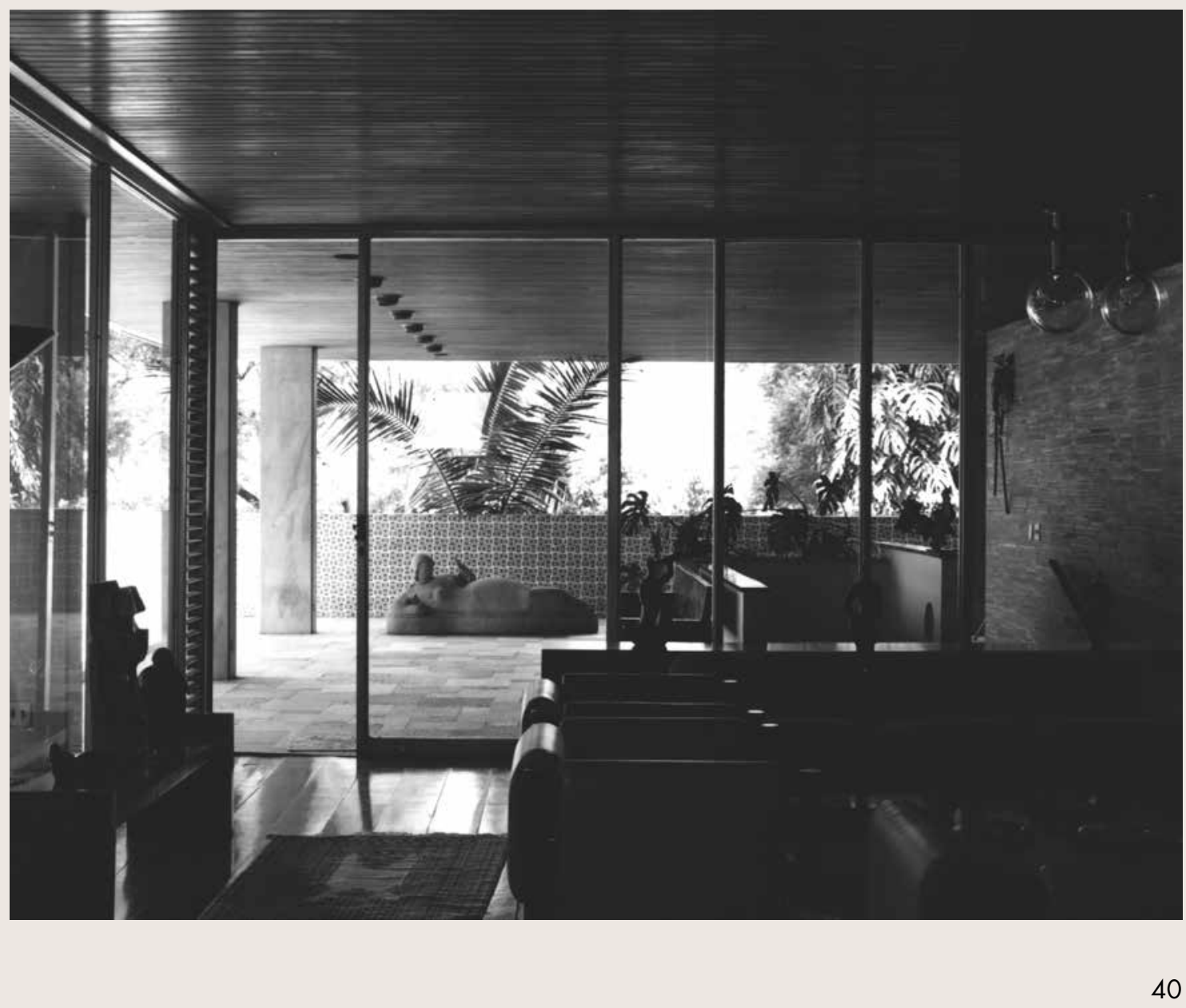



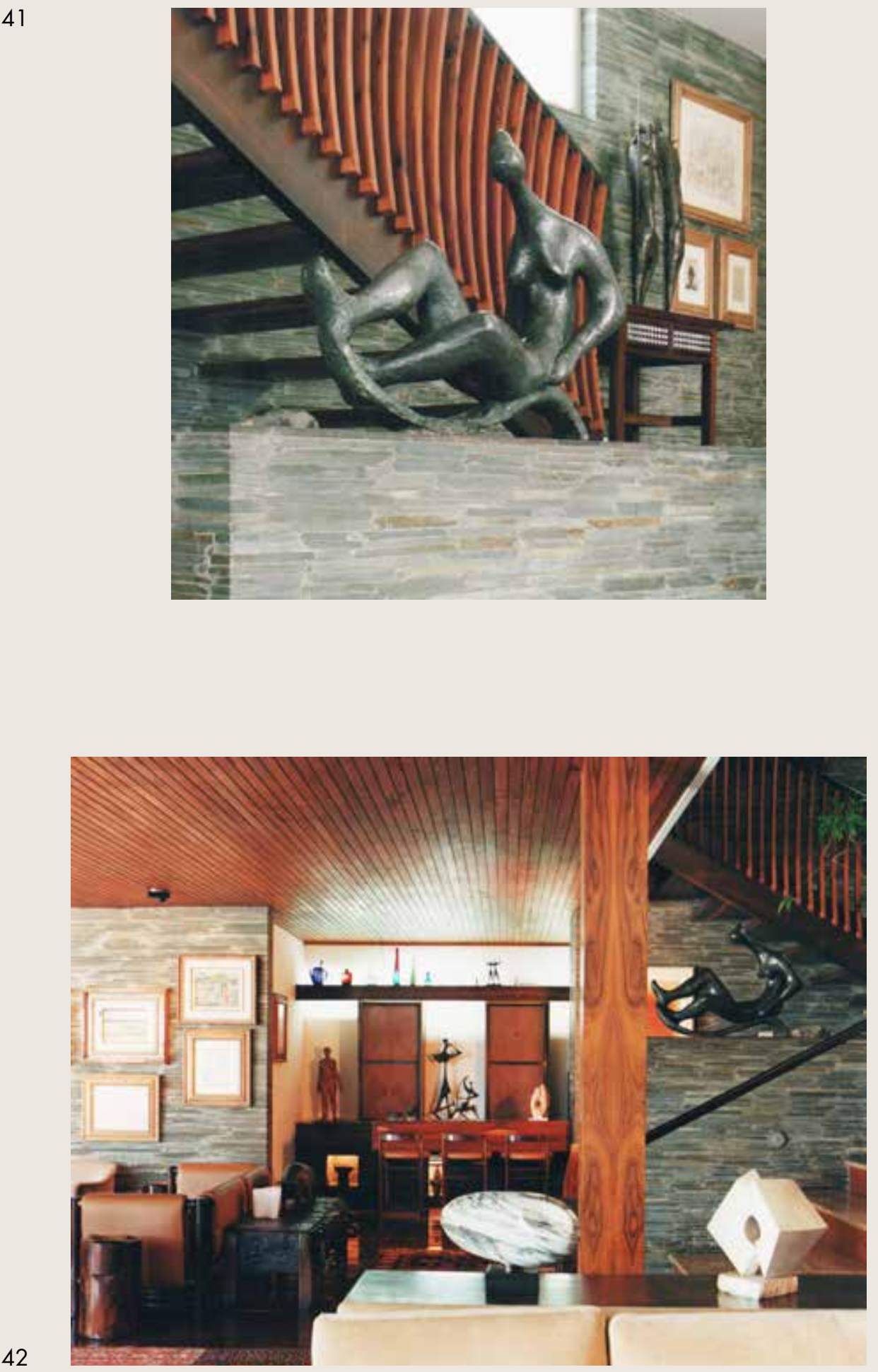


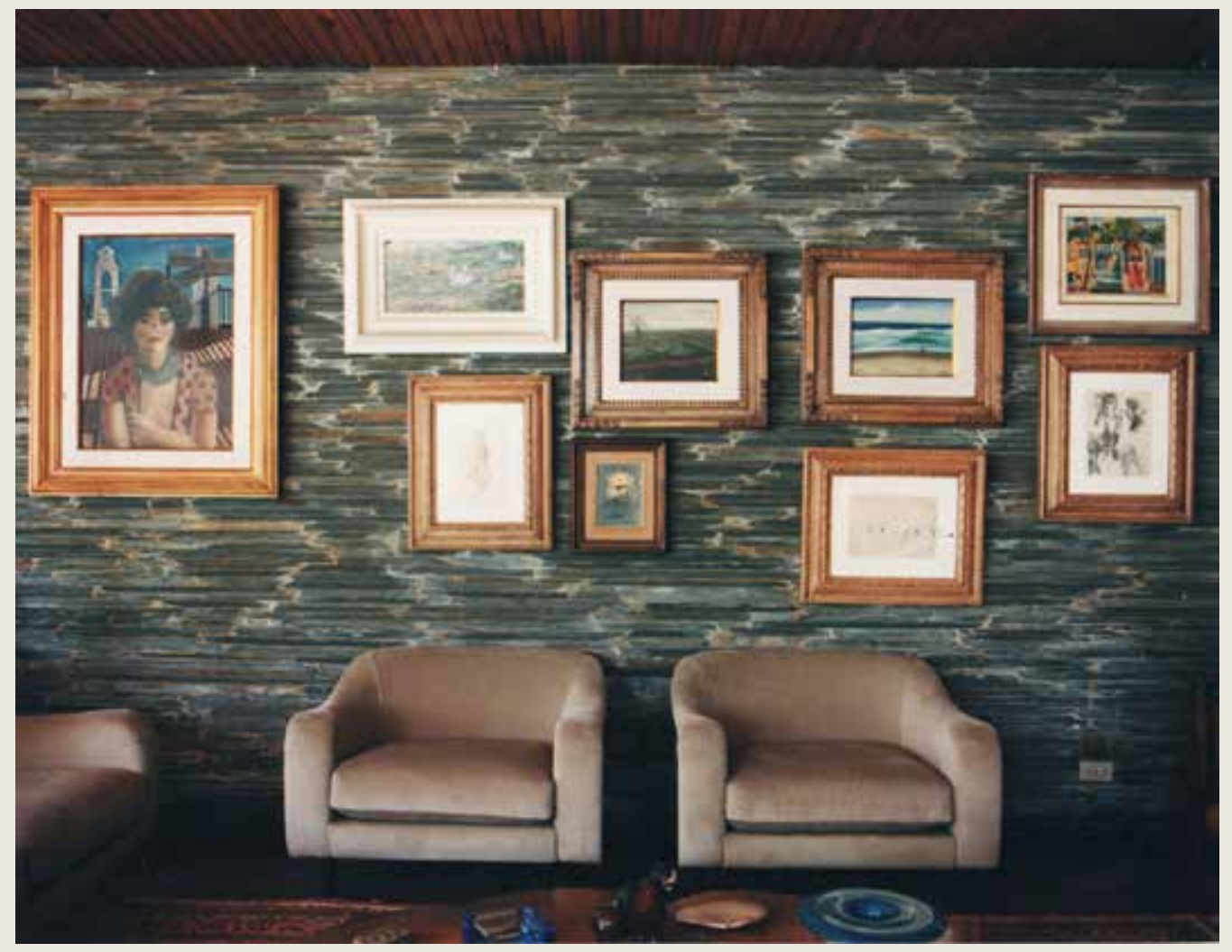




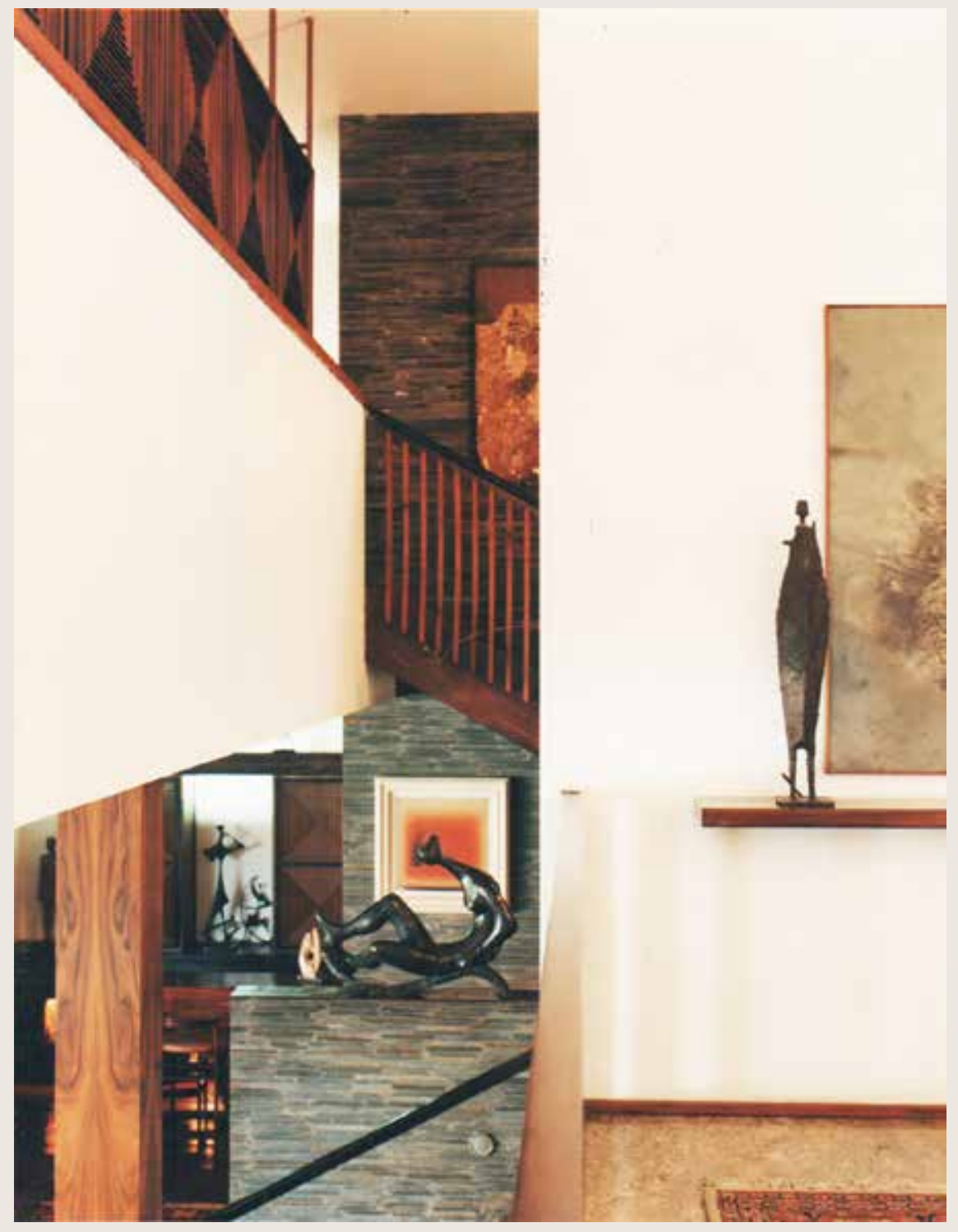



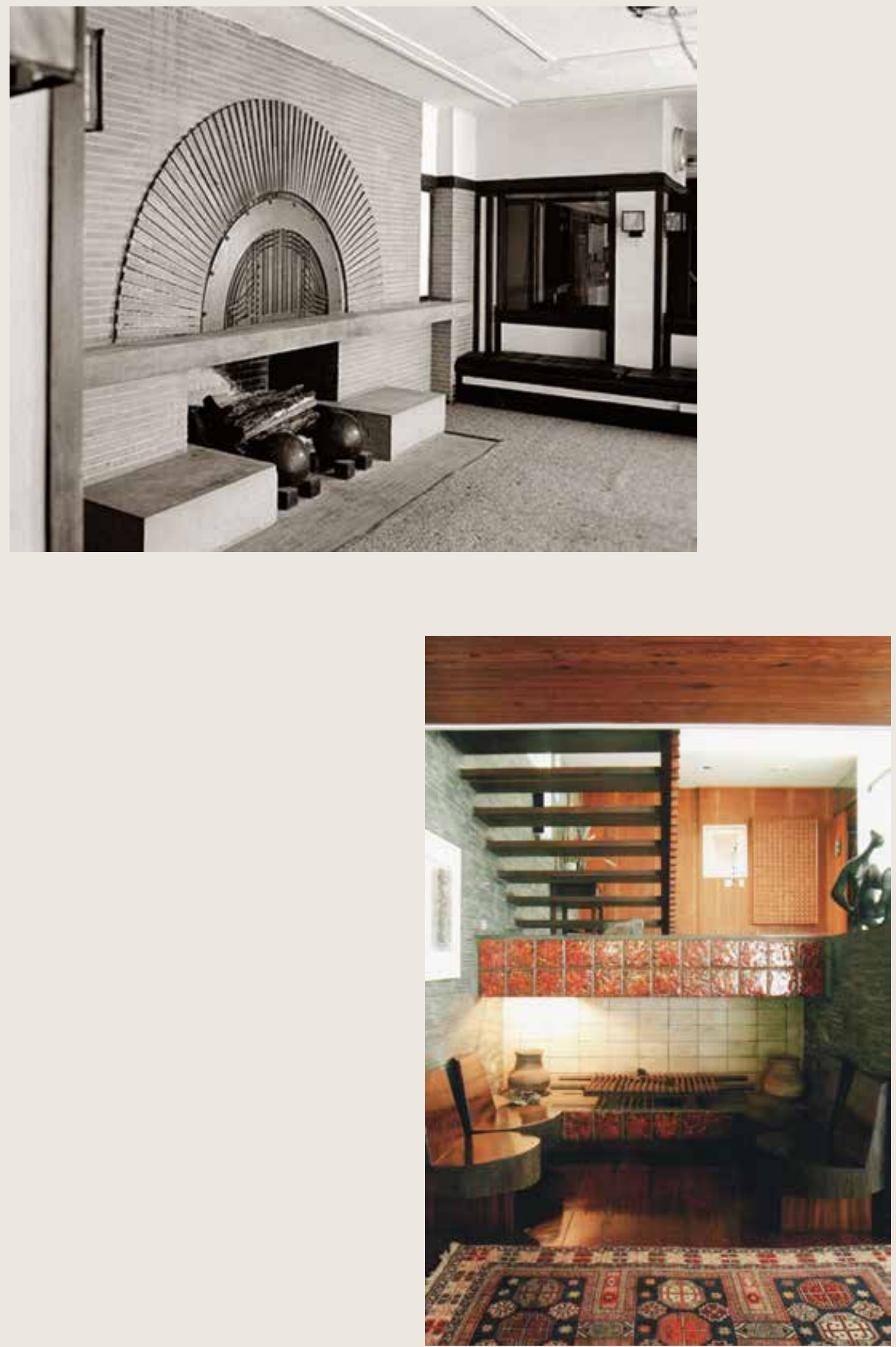


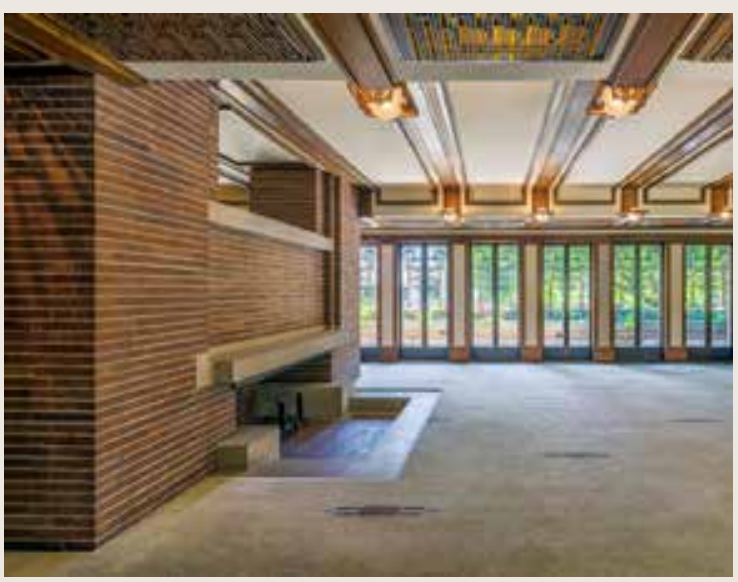

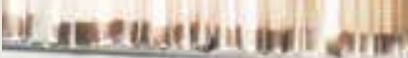
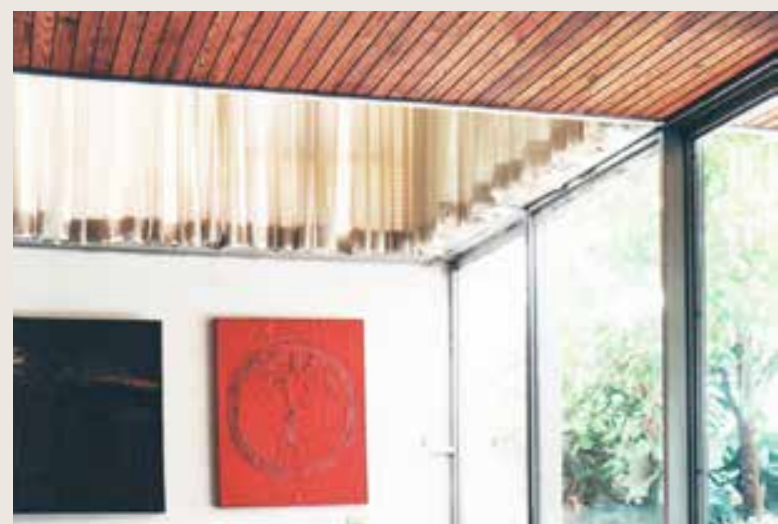

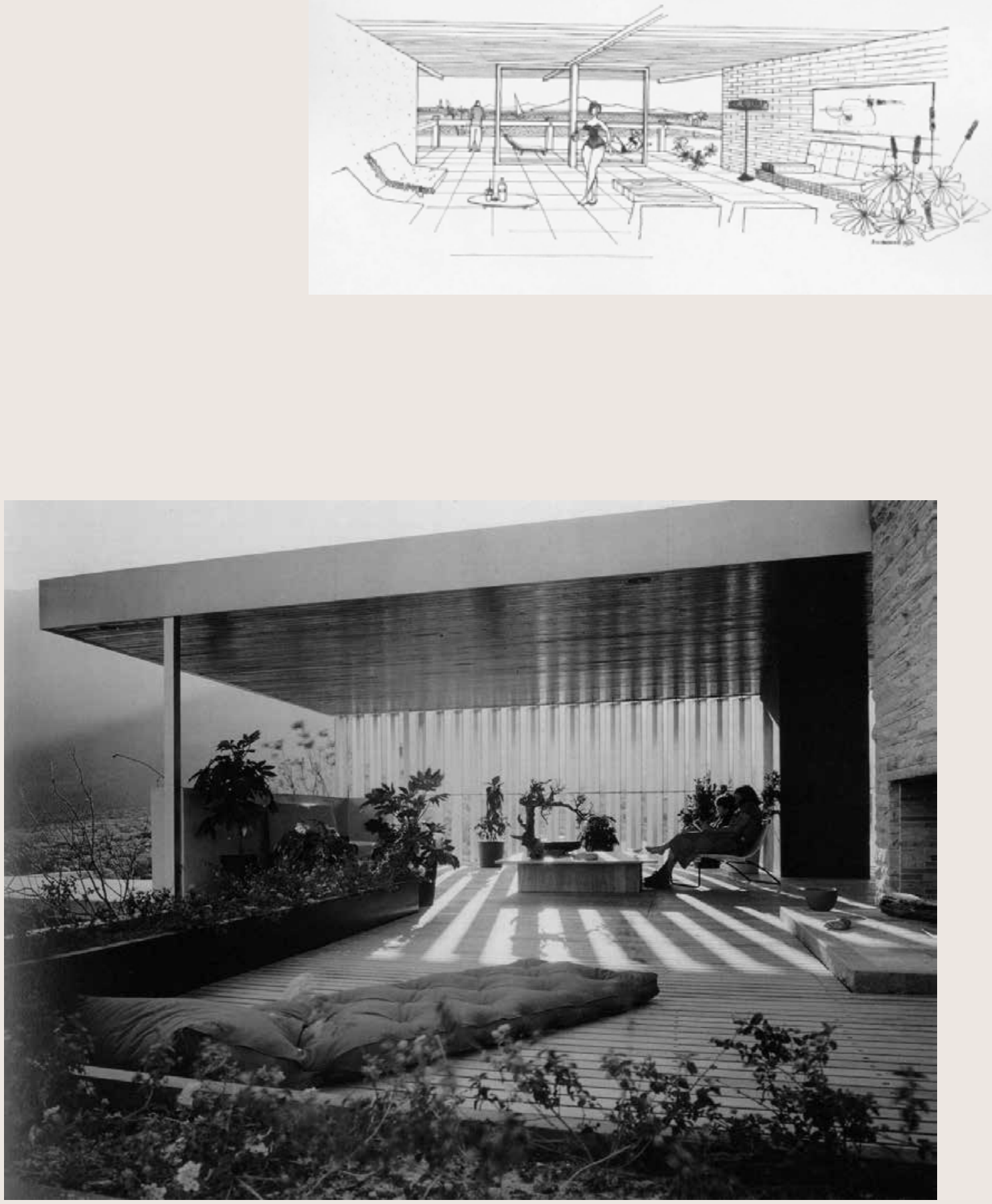

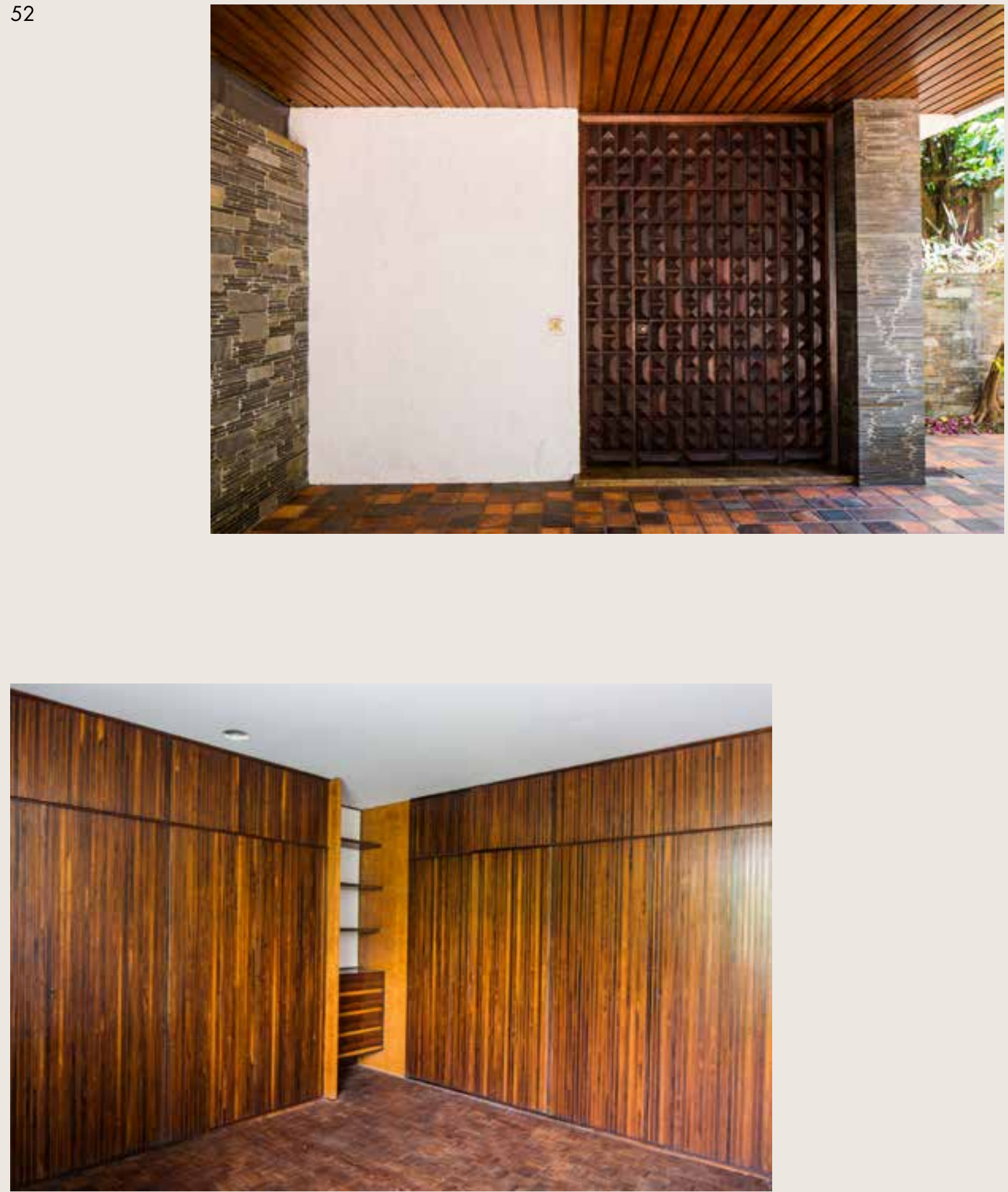

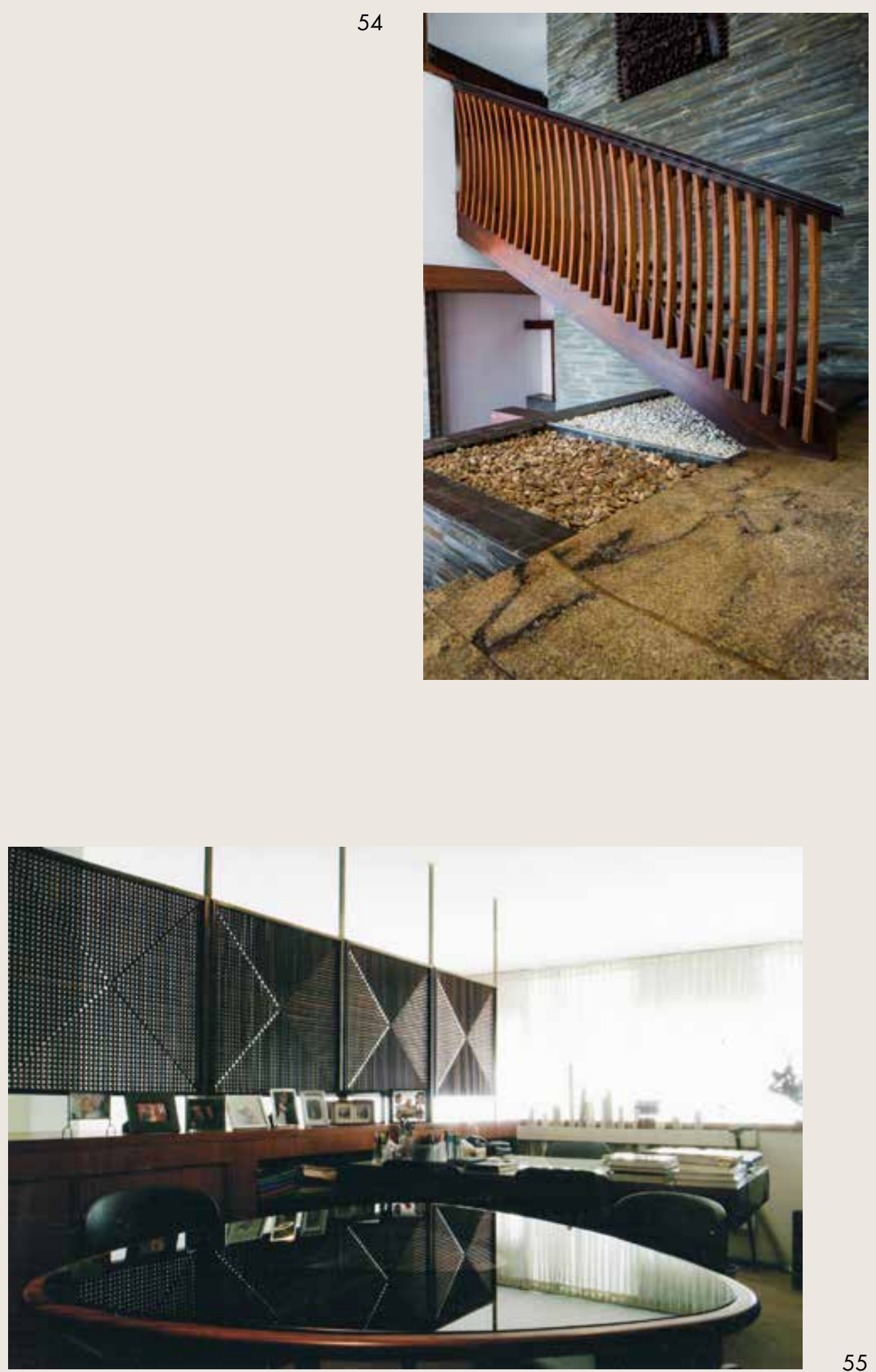

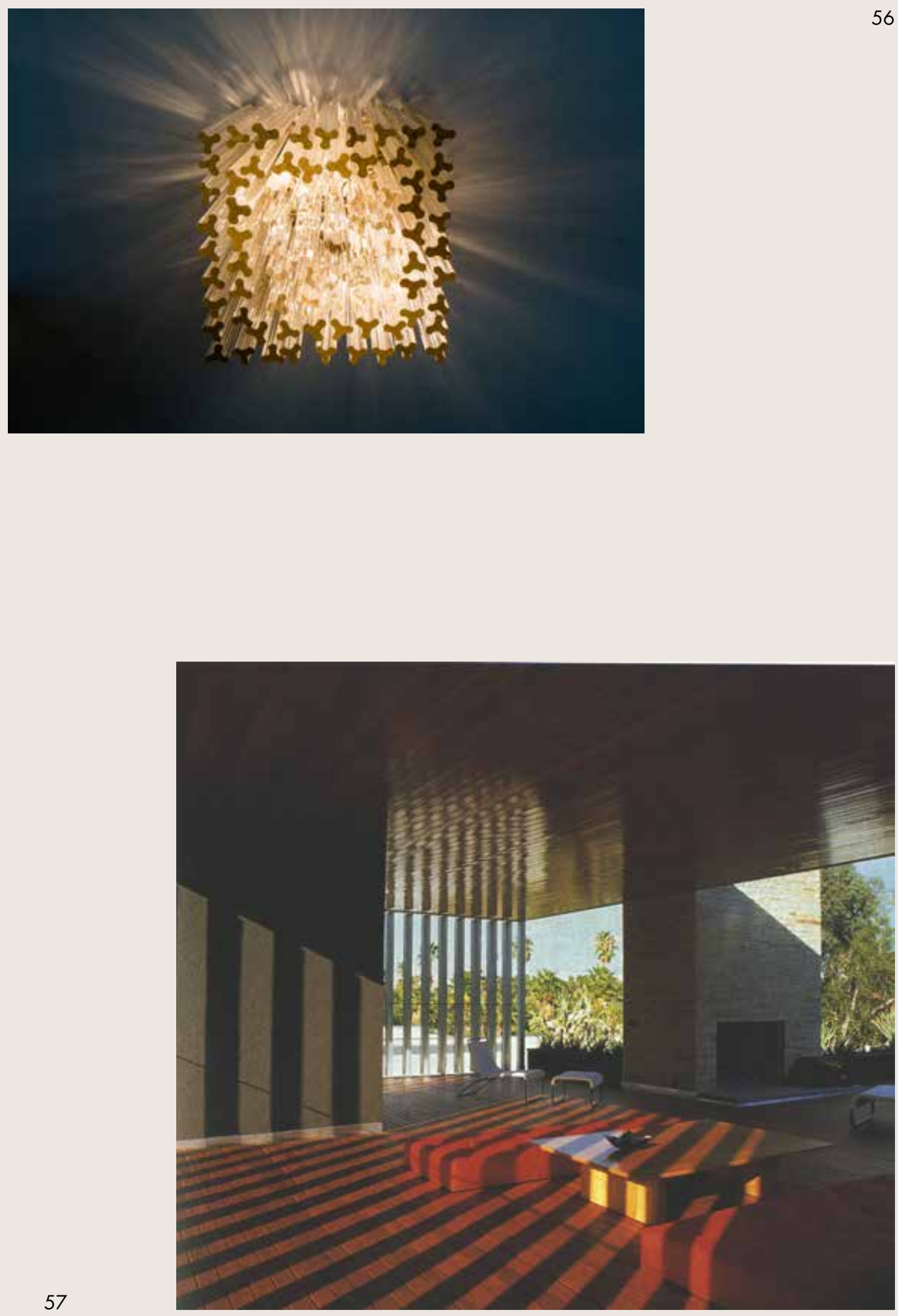


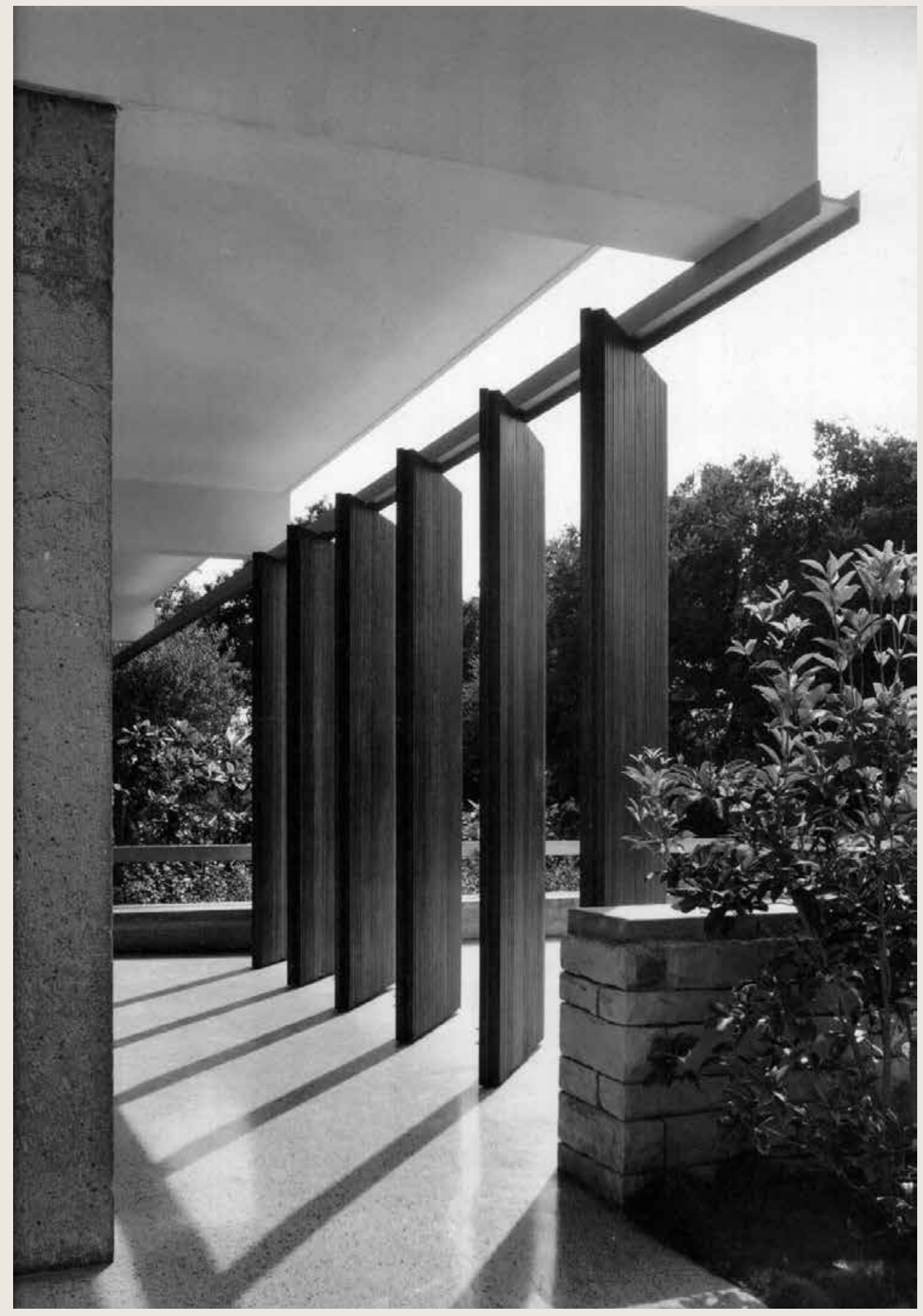




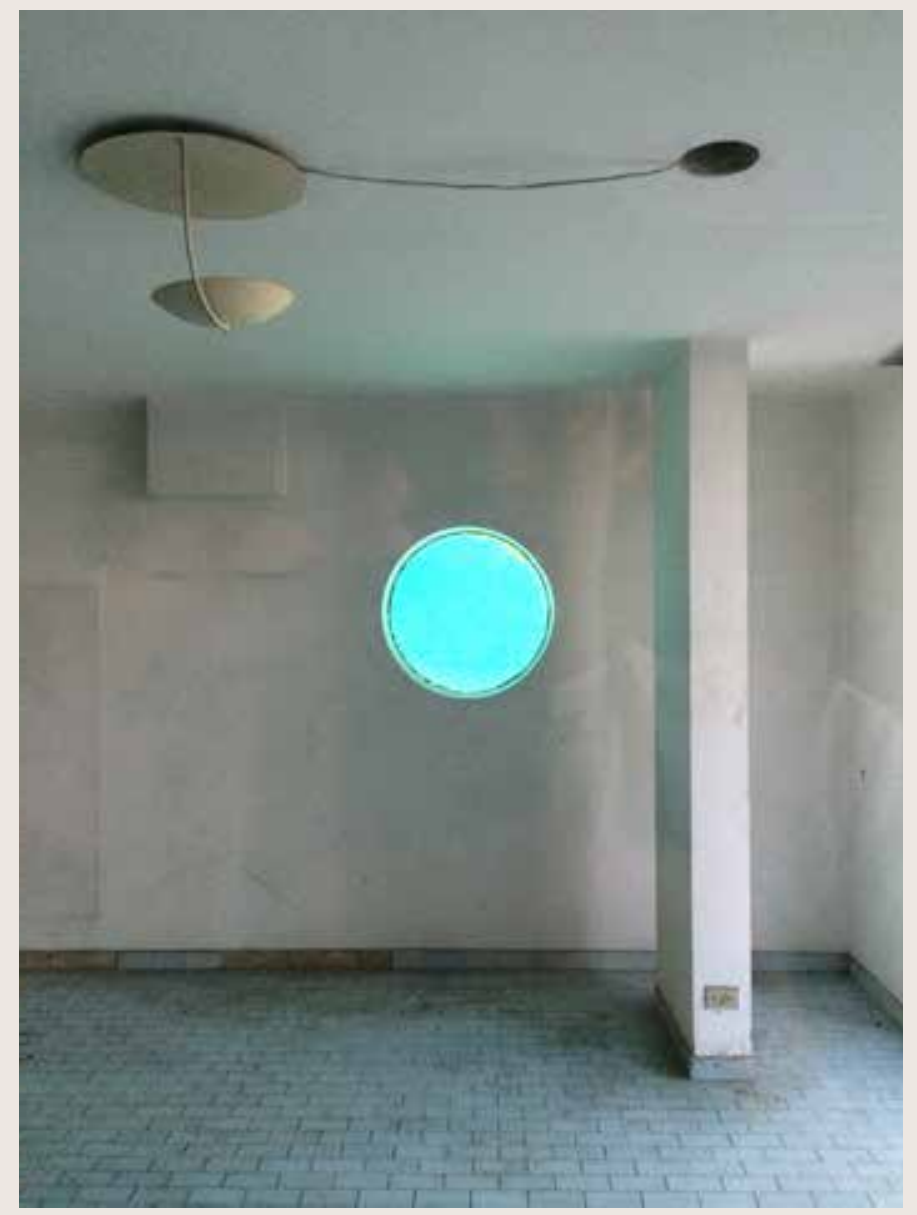



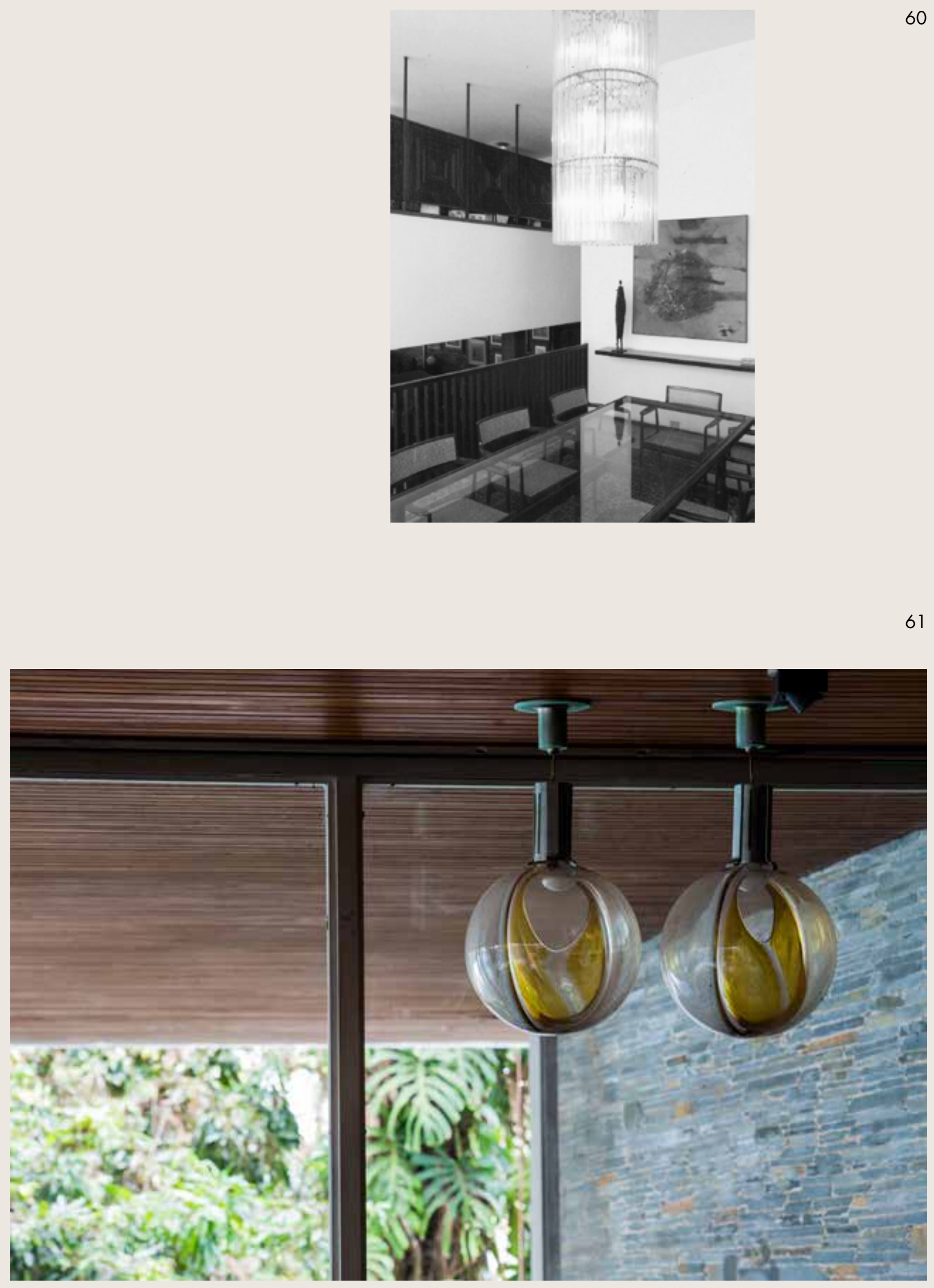


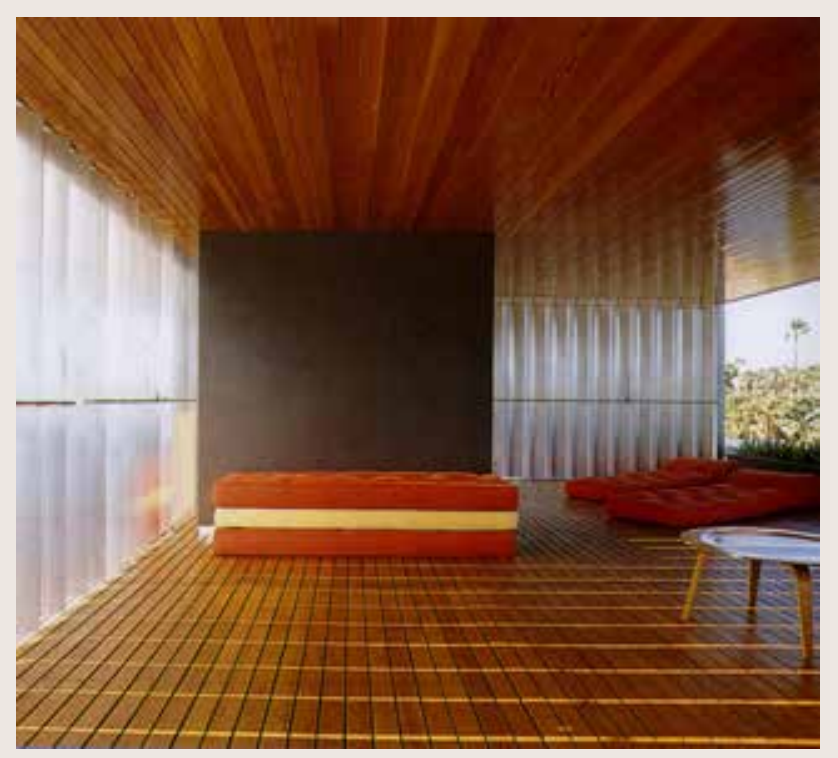




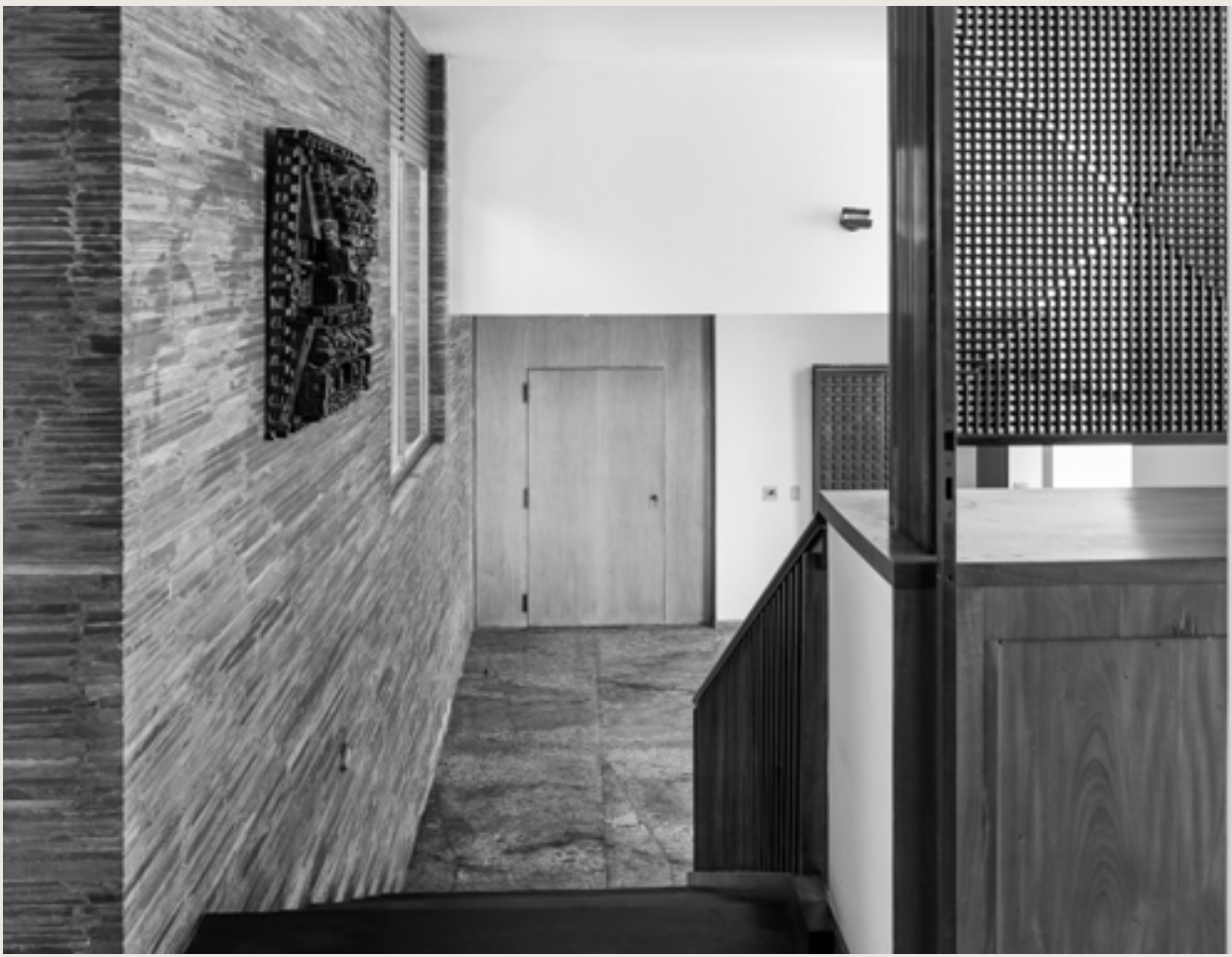


TENREIRO E A AMBIÊNCIA MODERNA 
"Ao analisar a produção de princípios dos anos 1950, Giedion aponta

as principais características daquela que já então se reconhecia como "arquitetura brasileira": o desenvolvimento de traços fortes no exterior dos edifícios, os avanços no tratamento dos espaços internos, os jogos de relações formais com a paisagem, etc., mas o que visivelmente mais

o impressiona - e certamente o que mais interessa hoje para nossa reflexão - é outra coisa: no Brasil, um certo nível de realização foi alcançado. Ainda que certas características possam ser especialmente visíveis no trabalho de algumas individualidades excepcionais, elas são

também evidentes no nível médio da produção arquitetônica: uma situação que não existe na maioria dos outros países."

Siegfried Giedion

A produção de Libeskind está inserida no notável e reconhecido conjunto da obra dos arquitetos modernos brasileiros, lugar onde as manifestações culturais atingiram excepcional expressividade na primeira metade do século XX, ainda que pertencentes ao contexto de um país economicamente periférico.

O surpreende arco temporal de apenas nove anos compreendido desde a sua formatura, em Minas Gerais, em 1952, até o ano de conclusão da sua casa, objeto central deste trabalho, em 1961, apresenta um conjunto total de quarenta e uma obras construídas que consolidaram uma linguagem, fundamentais para a compreensão do desenvolvimento da Arquitetura Moderna Brasileira, que também se forma e se apura num arco de tempo muito curto, de aproximadamente vinte e cinco anos: de 1936, ano em que foi projetado o edifício do Ministério da Educação e Saúde Pública, a 1960, ano da inauguração de Brasília.

Olhar a produção de Libeskind através da sua própria casa foi um caminho para compreender a efervescência política e cultural na história do país, um novo padrão estético "que podemos dizer sofisticado sem ser aristocrático". 1

Segundo Martins, ${ }^{2}$ há duas posições antagônicas, mas de certa forma complementares que possibilitam uma leitura sobre o desenvolvimento, estabelecimento e posterior disseminação da arquitetura moderna no Brasil.

1 WISNIK, Guilherme. "Modernidade congênita". p. 36-48. In ANDREOLI, Elisabetta \& FORTY, Adrian (org.). Arquitetura Moderna Brasileira. New York: Phaidon Press Limited, 2004.

2 MARTINS, Carlos Alberto Ferreira. "Há algo de irracional..." Notas sobre a historiografia da arquitetura brasileira. p. 132-133. In GUERRA, Abíilio (org.) Textos fundamentais sobre história da arquitetura moderna brasileira: v2. São Paulo: Romano Guerra, 2010. 
Esses dois argumentos estão de certa forma presentes na obra de Libeskind. Uma hipótese é que exista uma conexão da sua obra com a trajetória de desenvolvimento orgânico da arquitetura brasileira, desde os primórdios da Colônia, apontando sua capacidade de aclimatação, de adaptação progressiva dos modelos externos às condições climáticas, técnicas, materiais e sociais do país. Há, como personagem central dessa posição Le Corbusier, que impulsiona "o argumento narrativo de uma arquitetura brasileira que teve que se tornar moderna para voltar a ser legitimamente nacional."

Uma outra hipótese, segundo Geraldo Ferraz³, a arquitetura moderna é antes de tudo um fato internacional, "um produto das ideias do século 20, dado que sua adjetivação (...) pertence a um estado de espírito adstrito às transformações que se operam na vida do homem de nosso tempo". Atrelada à essa visão, a obra de Libeskind conecta-se com o resgate da tradição do racionalismo construtivo, pensando a síntese dos novos programas socialmente suscitados, as novas disponibilidades de recursos técnicos e materiais e o "estado de espírito moderno". Esta postura, alinhada ao estilo internacional e a busca por uma linguagem que desejava se libertar de um passado identificado com o peso de uma tradição cultural.

Há uma clara intersecção entre as posturas defendidas por Ferraz e a aproximação analítica da produção de Libeskind, pois a introdução da arquitetura moderna no Brasil está fundamentada no quadro das profundas alterações na vida econômica, política, técnica e social de São Paulo, a partir da Primeira Guerra Mundial.

Em relação à primeira postura, percebe-se, principalmente no início da sua obra uma forte influência de Lucio Costa, quando Libeskind trabalhou junto ao SPHAN, realizando os levantamentos gráficos e históricos de Ouro Preto, sob o comando de Sylvio de Vasconcelos. Essa conexão ainda se reafirma a partir do contato com a obra de Niemeyer, por ocasião das obras de Pampulha. À frente do projeto, Niemeyer promoveria a integração entre arquitetura e artes plásticas, convocando para colaboradores artistas modernos: Cândido Portinari, autor das pinturas e azulejos da Igreja; Athos Bulcão e Alfredo Ceschiatti, responsáveis pelas esculturas; e Roberto Burle Marx, a quem coube a concepção paisagística. Amigos de Libeskind que trabalhavam com Oscar Niemeyer o convidavam a visitar o escritório sempre que ele estava presente em Belo Horizonte.

Essa arquitetura sensível ao clima e às tradições locais, advinda dessa

3 FERRAZ, Geraldo. Warchavchik e a introdução da arquitetura moderna no Brasil: 1925 a 1940. São Paulo: Masp, 1965. p. 7-10 
tradição aparece no uso dos materiais como a madeira, por exemplo, como vis-

to na casa do arquiteto e em outros projetos de residências contemporâneos a este. A marcenaria, em especial desenvolvida por Joaquim Tenreiro, ressalta um trabalho artesanal, que em seu desenho aborda as questões de linguagem moderna, entretanto distancia-se da produção em série.

Já em relação à segunda postura, a linguagem predominantemente moderna se reafirma principalmente após a chegada de Libeskind em São Paulo e o desenvolvimento do projeto para o Conjunto Nacional. A partir daí cada vez mais percebe-se um refinamento da linguagem aliada ao espirito da época, da metrópole moderna, mas que talvez, a referência à arquitetura de Mies, aristocrática e dependente de mão de obra altamente qualificada e de utilização de elementos industriais perfeitos, "não poderia encontrar repercussão num país em que nenhum destes princípios poderia ser satisfatoriamente resolvido". ${ }^{4}$

Ou, ainda seguindo a mesma tese, a forma peculiar que o nacionalismo cultural assumiu no Brasil é a expressão de um povo que "concilia a vontade de progredir" a um "apego sentimental e racional ao passado".

Ainda cabe ressaltar, atrelada a uma busca da linguagem da época, mas que traz em sua gênese seu passado tradicional, a influência já pontuada anteriormente da Escola Californiana, através de um de seus mais significativos representantes - Richard Neutra.

Neutra, que estudou com Adolf Loos em Viena antes da sua chegada em Chicago, em 1923 para trabalhar com Frank Lloyd Wright, se tornou um dos maiores expoentes do Modernismo nos Estado Unidos. Seu trabalho se refere amplamente à arquitetura doméstica e sua força está predominantemente marcada em sua excepcional habilidade de implantar suas casas na paisagem e tirar partido dos materiais locais. Pode-se denotar uma estreita relação entre Neutra e Schindler (Rudolph Michael Schindler, Viena-1887/Los Angeles-1953), seu conterrâneo e amigo, principalmente no modo de trabalhar com a luz natural, a luz do dia, a luz do sol e o uso imaginativo da paisagem, de onde Libeskind retirou várias lições para aplicar em seus projetos de residências, mas não apenas nestes, pois essa fusão entre os dois mundos - o da pureza e o da síntese e o da referência às coisas materiais - estará presente também nos seus projetos desenvolvidos para outros programas, por exemplo, Edifício Arper (1959) e os projetos correlatos a ele - Edifício Arabá (1961) -

4 Bruand, rebatendo as criticas de Max Bill, argumenta pela impossibilidade de absorver no Brasil o modelo de Gropius, pois este era marcado pelo duplo conflito das relações entre arte e indústria e da democracia fatal da arte, quando "nenhum desses problemas tinha sua razão de ser no Brasil". 
5 Joaquim Albuquerque Tenreiro (Melo Guarda, Portugal 1906 - Itapira SP 1992). Designer, escultor, pintor, gravador e desenhista. Filho e neto de marceneiros, aos dois anos de idade muda-se para o Brasil com a família, fixando residência em Niterói, Rio de Janeiro. Retorna a Portugal em 1914, onde ajuda o pai a realizar trabalhos em madeira e inicia aulas de pintura. Volta a viver no Brasil entre 1925 e 1927. Em 1928, transfere-se definitivamente para o Rio de Janeiro, passando a freqüentar o curso de desenho do Liceu Literário Português e faz cursos no Liceu de Artes e Ofícios. Em 1931, integra o Núcleo Bernardelli, grupo criado em oposição ao ensino acadêmico da Escola Nacional de Belas Artes - Enba. Na década de 1940, dedica-se à pintura de retrato, de paisagem e de natureza-morta. Entre 1933 e 1943, trabalha como designer de móveis nas empresas Laubissh \& Hirth, Leandro Martins e Francisco Gomes. Em 1942, realiza para a residência de Francisco Inácio Peixoto seu primeiro móvel moderno. Em 1943, monta sua primeira oficina, a Langenbach \& Tenreiro e, alguns anos depois, inaugura duas lojas de móveis; primeiro no Rio de Janeiro e, posteriromente, em São Paulo. No final da década de 1960, Joaquim Tenreiro encerra as atividades na área da concepção e fabricação de móveis para dedicar-se, por mais 20 anos, exclusivamente às artes plásticas, principalmente à escultura. Em 1969, executa um painel para a Sinagoga Templo Sidon e, em 1974, dois painéis para o auditório do Senai, ambos na Tijuca.

Joaquim Tenreiro nasce em Melo, pequena aldeia de Portugal, e fixa-se no Rio de Janeiro em 1928. Filho e neto de marceneiros, aprende a trabalhar com a madeira ainda criança. Em 1929, cursa desenho no Liceu Literário Português, paralelamente estuda no Liceu de Artes de Ofícios. Participa, em 1931, do Núcleo Bernardelli, tendo como colegas, entre outros, os pintores José Pancetti (1902 - 1958) e Milton Dacosta (1915 - 1988). Trabalha, entre 1933 e 1943, como projetista nas firmas Laubish \& Hirth, Leandro Martins e Francisco Gomes, especializadas em móveis de estilos francês, italiano e português - "luízes de todos os números e renascimentos tardos de 400 anos", como relata Tenreiro, ironicamente. Funda, em 1943, a empresa Langenbach \& Tenreiro, colocando em prática sua concepção de móvel moderno.

Torna-se conhecido como designer em 1942, quando recebe a primeira encomenda de móveis, para a residência de Francisco Inácio Peixoto, em Cataguases, interior de Minas Gerais, projetada pelo arquiteto Oscar Niemeyer (1907 - 2012). Esses são os primeiros exemplares concebidos, projetados e realizados por ele, que se distinguem pela sobriedade e beleza das formas e pela sábia utilização de madeiras brasileiras. Dialoga também com a pureza das formas arquitetônicas de Niemeyer.

A Poltrona Leve (ca.1942) - realizada nas versões clara, em madeira marfim, e escura, em imbuia, com tecido estampado por Fayga Ostrower (1920 - 2001) - é uma de suas produções mais conhecidas, concebida de acordo com a ideia de que a mobília brasileira deve ser formalmente mais leve. Nas palavras de Tenreiro, leveza que nada tem a ver com o peso em si, mas com a graça e funcionalidade. Atestando a modernidade dos móveis feitos no Brasil, o design de Tenreiro tem por princípios a adequação à função e o despojamento.

$\mathrm{Na}$ Cadeira de Três Pés (ca.1947), inova ao associar a geometria a um uso muito particular das cores das madeiras nacionais. Composta de combinações de madeiras de diferentes tonalidades (imbuia, roxinho, jacarandá, marfim e cabreúva), essa cadeira apresenta um refinado jogo cromático. O uso da cor, anteriormente restrito ao acabamento dos móveis, torna-se um conceito central em sua criação. Na Cadeira de Balanço (ca.1948) utiliza a palhinha - uma tradição do móvel colonial brasileiro, retomada pelo artista - e o jacarandá. Como outros móveis de Tenreiro desse período, ela tem uma aparência leve e luminosa, contrastando com a mobília sólida e sóbria, criada anteriormente para a firma Laubisch \& Hirth.

Em algumas cadeiras e poltronas, o artista explora os efeitos plásticos da trama em palhinha e outros materiais que evocam o trançado e a cestaria indígenas. O uso de madeira e fibras naturais associa-se à necessidade de adequar os móveis ao clima tropical. Juntamente com estas composições orgânicas, outras peças de Tenreiro como, por exemplo, a Cadeira Estrutural, 
em consonância com a casa, o "apuro" do desenho através do projeto comple-

to da marcenaria, não apenas do mobiliário, mas de vários outros elementos como demonstrados a seguir.

Libeskind e Tenreiro eram amigos. Libeskind já havia realizado alguns ensaios de projeto e de fabricação de peças de mobiliário ainda na fase de recémformado, mas essa foi uma atividade para a qual não se dedicou com maior ênfase.

A relevância da presença do mobiliário de Tenreiro na casa revela uma espécie de simbiose entre o projeto da casa e do mobiliário, uma troca de experiências entre Libeskind e Tenreiro, pois há a participação efetiva de Tenreiro no projeto da casa. Não se trata, portanto, de peças do mobiliário de Tenreiro que foram utilizadas como decoração por Libeskind, mas de peças desenhadas para esta casa no âmbito das discussões travadas entre eles para a concepção dos espaços da casa.

A presença maciça do mobiliário, peças de iluminação e de composição de ambientes de autoria de Joaquim Tenreiro no interior da casa chama a atenção e leva a raciocinar a respeito dos aspectos e critérios de escolha de Libeskind para construir o ambiente interior da sua casa, mas, sobretudo, revela um momento de efervescência cultural do Brasil, nos anos 1960, a originalidade do produto nacional e sua receptividade dentro e fora do país, bem como a maior ênfase nas relações entre aspectos da cultura popular e do design.

O dinamismo do meio artístico e cultural brasileiro nos anos 1960 viveu um cruzamento de crises nos diversos setores das manifestações artísticas, que, segundo Maria Loschiavo, ${ }^{6}$ corresponde à constituição de um novo projeto estético, cuja tônica principal era a luta por uma arte autenticamente nacional e de contestação.

apresentam linhas retas e elementos geométricos, regulares, empregando estruturas tanto de madeira (1957) quanto de metal (1961). O conhecimento profundo da madeira permite a Tenreiro obter a qualidade poética de suas obras.

No fim da década de 1960, por questões pessoais e também de mercado, encerra as atividades de designer e dedica-se principalmente à escultura. Produz relevos, treliças e colunas em madeira policromada, nas quais se destacam a combinação da produção artística e o amplo conhecimento do trabalho. Algumas soluções, contidas na funcionalidade dos móveis criados por ele, são utilizadas de maneira mais livre na escultura. As técnicas de composição cromática empregadas, por exemplo, na Cadeira de Três Pés, são retomadas posteriormente em alguns relevos, em que o artista explora as diferenças de cor, texturas e os veios da madeira, como em Círculos (1979). A produção de Tenreiro alia, portanto, as características modernas do despojamento e simplicidade ao uso de materiais brasileiros. Assegura às peças produzidas uma qualidade artisticamente elaborada, renovando, assim, o desenho do móvel brasileiro. In: ENCICLOPÉDIA Itaú Cultural de Arte e Cultura Brasileiras. São Paulo: Itaú Cultural.

6 SANTOS, Maria Cecília Loschiavo. Móvel Moderno no Brasil. São Paulo: Editora Senac São Paulo/ Editora Olhares, 2017.p. 173 
De todos os designers de seu período, Tenreiro é, certamente, o mais representativo, seja pelo vigor de sua obra, seja pela alta qualidade de sua produção, seja porque nos remete mais profundamente às nossas tradições lusas no uso corriqueiro e elegante dos jacarandás e da palhinha trançada, destacado exemplo do design têxtil tradicional.

É preciso lembrar que, em mais de trinta anos de atividade como designer de móveis, Tenreiro conseguiu unir o artista ao técnico, numa proporção bem ponderada, trazendo soluções que se caracterizavam, sobretudo, pelo apuro, refinamento técnico e sobriedade. Assim, a decoração de interiores deixou de ser encarada como "[...] uma espécie de vaidade sem justiça, um orgulho sem lógica. Entusiasmo momentâneo que não vem de nenhuma necessidade de expressão plástica, nem de uma experiência e trabalho constante, assumindo maior dignidade, podendo ser considerada "[...] como um movimento de arte, um movimento criador, onde já se possam contar contribuições novas à decoração, criações com caráter próprio capazes de firmar-Ihes os fundamentos [...] Aí, a decoração não é um meio de que nos servimos para esconder um canto feio, com artifício, com elementos extras, mas uma força que modela, que cria móveis que preenchem finalidades funcionais e estéticas, cortinas que temperam a luz e tapetes que ligam a composição". ${ }^{7}$

Este caráter nacional, ou processo de aculturação a partir do enriquecimento do uso de elementos nativos implementam a absorção de padrões internacionais, e já estão presentes no repertório de Libeskind. Pode-se dizer que essa formulação é uma espécie de regionalismo, atento às linguagens estrangeiras, mas, enquanto ideário estético, buscando a expressividade brasileira, sobretudo reforçada na presença de Tenreiro como parceiro de construção de vários ambientes da casa.

"O caráter original do móvel moderno brasileiro emergiu da convivência entre esses dois contextos, da simultaneidade da produção artesanal e seriada; de metodologias intuitivas e racionalistas; da cópia mimética e do design autóctone. Veja-se, por exemplo, a extraordinária contribuição de Joaquim Tenreiro, que durante anos submeteu-se à produção mimética dos estilos e só mais tarde teve a oportunidade redentora para fazer o moderno. Nesse sentido, o Brasil se constituiu num laboratório continuamente aberto à experimentação, potencializada em determinados contextos histórico-políticos". ${ }^{8}$

7 TENREIRO, Joaquim. "Decoração: sobriedade, distinção e acolhimento". Módulo. Rio de Janeiro, 1(2):58-61. Agosto, 1955.

8 SANTOS, 2017.p. 17 
A modernização da arquitetura e da cultura brasileira, e conjuntamente a modernização do mobiliário, ainda segundo Loschiavo, foi se tornando mais complexa e enriqueceu-se com o uso de elementos nacionais: os tecidos, as fibras naturais e outros materiais da terra, trazendo mais autonomia para a produção do móvel e caracterizando obras significativas, elaboradas dentro de um marco estilístico que respondeu mais adequadamente à nossas condições.

A casa é, dessa forma, um laboratório, um campo de experimentações das peças recém desenhadas e construídas por Tenreiro aplicadas no espaço recém idealizado e materializado por Libeskind, o que permite observar ainda que, de forma muito sucinta, o caráter de marginalidade a que o móvel sempre esteve ligado é colocado em questão pela arquitetura moderna, ${ }^{9}$ pois a partir de então, o móvel passa a ser visto como elemento complementar e essencial no projeto arquitetônico, tendo a mesma importância deste.

Mas a presença de Tenreiro na casa não está limitada às peças do mobiliário, pois há outros elementos essenciais de construção dos espaços desenhados por ele.

Divisórias, biombos, guarda-corpos, portas, fechamentos de armários, luminárias são parte integrante de um conjunto de peças que se relacionam entre si e com a arquitetura.

Libeskind poderia fazer a opção por peças ícones do catálogo internacional consagrado do design para compor a sua arquitetura, mas o que se observa aqui é algo que reafirma a construção do caráter dessa arquitetura-manifesto na opção pelo uso das madeiras nacionais, pelas trama e fibras brasileiras na obra de Tenreiro que "revela essa proximidade familiar e quase amorosa com a madeira: seu fascínio pela textura da fibra, pela organicidade e tatilidade transparece no jogo de volumes, formas e cores que presidem a sua produção".

Se por um lado o mobiliário de Tenreiro funcionou quase como um manifesto em favor do estilo moderno, por outro, em relação ao modo de produção, é preciso lembrar que era ainda completamente artesanal: o protótipo tinha uma tiragem mínima e, muitas vezes, ficava no exemplar único, por questões de compromisso com o cliente.

É exatamente o caso de algumas peças presentes na casa de Libeskind, projetadas exclusivamente para ela, no ano de 1961.

9 De acordo com Mário Pedrosa, "A revolução da arquitetura não é, portanto, puramente externa. Ao contrário, ela está direcionada para o exterior e para o interior do edifício, onde nos permite, pela primeira vez, desde os tempos pré-históricos, quando o homem primitivo vivia o interior da terra, ter uma consciência física do espaço interior, da sua existência física". In: PEDROSA, Mario. Dos murais de Portinari aos espaços de Brasília. São Paulo, Perspectiva, 1981. p.253 
A partir de um inventário realizado pelas visitas, pelas imagens apoiadas em bibliografia de referência, foi possível identificar as seguintes peças:

- Conjunto da sala de jantar: mesa em madeira e tampo de vidro e dez cadeiras com acento e encosto em palhinha trançada;

- Móvel aparador da Sala de Estar (com pé-direito duplo), com tampo em mármore (peça fixa);

- Bar e três banquetas em madeira com assento estofado;

- Quatro bancos de tronco de vinhático gema de ovo na área da lareira;

- Sofás da sala de estar (contígua à lareira e bar) em estrutura de madeira com mantas soltas em couro |Santos, (2017), p. 125 e 129|;

- Portas do acesso principal, do acesso à área íntima e painel, portas e fechamentos de armários do bar, guarda-corpo da escada, divisória do escritório e painel, e móvel do escritório e guarda-corpo da sala de jantar que foram todos desenhados exclusivamente para esta casa.

- As duas cadeiras de balanço na sala de estar com pé-direito duplo: cadeira de balanço estruturada em madeira com assento e encosto em couro, de 1947 |Santos, (2017) p. 126| e cadeira de balanço em jacarandá e palhinha trançada, de 1959 |Santos (2017), p.117|foram itens de série, com uma tiragem maior.

- Ainda completa este conjunto, três luminárias em cristal e latão, também de Tenreiro, na sala de jantar, no vestíbulo de acesso à área íntima e na sala de estar contígua à lareira. (Data não identificada)

Os elementos projetados por Tenreiro que compõe a arquitetura da casa sugerem que houve um diálogo criativo entre o arquiteto e o design, pois esta fusão extrapola a decoração ou a ocupação dos ambientes por determinado mobiliário, ou ainda um arranjo compositivo como em um cenário. Há uma camada expressa pela madeira que reforça a expressividade buscada por Libeskind no trato das superfícies. Mas neste caso, a madeira não se restringe a ser um elemento de revestimento, ela é empregada como a própria operação de domínio material. A cargo de Tenreiro, essa expressividade contida colabora para a construção da estrutura espacial pretendida por Libeskind, sobretudo quando a intenção era revelar de modo parcial as vistas internas da casa. Essa situação é percebida no escritório e na sala de jantar com a utilização dos painéis e guarda-corpos que permitem a passagem da luz, mas conferem a privacidade necessária para o recinto do trabalho (no caso do escritório). 
Este elemento de fechamento parcial é um painel com desenho geométrico (uma superfície em trama com pequenas perfurações), composto de seis quadrados estruturados com metal. Faz alusão à trama da palhinha trançada das cadeiras e ao mesmo tempo a um "muxarabi".

A trama empregada em duas direções permite observar um desenho em " $x$ ", que juntos, dois a dois, esses quadrados formam losangos.

A luz filtrada resultante da incorporação deste elemento no ambiente proporciona a leitura geométrica deste painel, o que reforça a delicadeza e o rigor adotados por Tenreiro no uso do material. Os quadrados dessa sequência em linha são vistos desde o vestíbulo principal de acesso à casa e o mesmo desenho será utilizado nas portas dos armários do bar repetindo a proporção, mas com outras dimensões e outro arranjo compositivo. Neste caso, o mesmo recurso de desenho é utilizado, mas com outra intenção, pois não se trata de uma divisória ou biombo, e a passagem da luz, por sua vez, não é relevante. Mas a utilização do elemento permite a passagem do ar, proporcionando a ventilação necessária para um armário numa área mais fechada e úmida da casa.

Os guarda-corpos aparecem em duas versões. Na sala de jantar ele é a continuidade de um painel que tem o arranque no piso da sala de estar com pé direito duplo. Aí ele é a extensão de forma intercalada deste painel, um negativo-positivo das ripas de madeira que funcionam como superfície para esta sala, conferindo maior aconchego, e como um guarda-corpo para a sala de jantar que se lança no vazio.

Numa vista frontal a partir da sala de jantar em direção a este guarda-corpo é possível perceber a relação que ele estabelece com o painel do escritório, cada um ocupando patamares distintos da casa. Essa relação de vista velada permite o controle visual de ambos os ambientes e mantém a ideia de que na casa todos os espaços se comunicam. Isso reitera a afirmação colocada de que Tenreiro também projetou a casa num sentido metafórico (ele está presente na casa mesmo quando ela está vazia), mas não menos real, pois só seria possível compreender as intenções do projeto de Libeskind através da enorme sintonia entre ambos.

Devido ao desenho vazado do guarda-corpo da sala de jantar também é possível vislumbrar a vista externa da piscina através das generosas aberturas transparentes.

O guarda-corpo da escada surge apenas no lance que conecta os dois vestíbulos (acesso principal e área íntima) justamente onde a escada é vazada e formada apenas por tábuas de piso (sem os espelhos) e aí aparece um desenho 
mais elaborado, em curva suave, também repetindo a ideia do guarda corpo anterior alterando os cheios e vazios na sua configuração.

Os únicos elementos que empregam a curva em toda casa são este guarda-corpo da escada e as luminárias (pendentes) apontados na relação acima.

A sinuosidade do guarda-corpo é bastante delicada e apenas percebida a partir de determinados ângulos de visão, fato que reforça o caráter dessa arquitetura em associação com o design.

Cabe ressaltar que a parede oposta a este guarda-corpo é de pedra, resolvida num grafismo horizontal que se contrapõe ao ritmo vertical das peças do guarda-corpo.

Na casa há sempre um duelo entre áreas abertas e fechadas, transparências e opacidades, e no caso da escada essas relações dicotômicas também ficam evidentes. No lance que conecta a escada com a sala de estar a opção é por uma massa construída, bem assentada e apoiada na cota da lareira e do bar. Neste caso não há guarda-corpo vazado, posto que a intenção é resguardar, fechar, comprimir. De modo que cada elemento proposto por Tenreiro entende o ponto sensível onde a arquitetura de Libeskind quer chegar e as imagens da casa vazia são ainda mais significativas na explicitação dessa realidade.

Se no painel do escritório a solução era o negativo na subtração da matéria para conferir a passagem da luz, no desenho das portas (acesso principal e acesso ao vestíbulo para área íntima) a solução é o oposto. Tenreiro opta por um desenho geométrico (aqui a matriz também é o quadrado, assim como no painel do escritório), mas numa operação contrária, de extrusão da peça geométrica, conferindo tridimensionalidade aos elementos. Se no painel a regra era a subtração, e a partir da trama era possível observar o desenho formado, nas portas, também o é, mas através de um processo que adiciona mais matéria, investigação também presente nas pinturas e nas cerâmicas de Libeskind, onde há um objeto que salta do seu campo bidimensional, que sugere uma experiência tátil.

O painel do escritório é um véu, se assemelha à trama de um tecido, por isso recorre ao desenho da palhinha trançada, mas nas portas comparece uma lógica diferente, porque a matéria e o volume, ainda que geometricamente rigorosos, desenham a luz e a sombra em cada face do polígono extrudado. Ou seja, a natureza da luz em cada um dos objetos é distinta e essa também é uma questão importante para Libeskind em seus projetos: conferir muitas possibilidades e nuances de iluminação para os espaços, pois assim o ambiente está qualificado para além das estruturas convencionais do desenho. Isso está posto em todas as escalas, desde a decisão de aberturas, tratamentos de gran- 
des planos verticais e horizontais assim como nos elementos menores (não em importância) aqui apontados.

Os objetos de iluminação (três luminárias) de autoria de Tenreiro são realizados com outros materiais, o cristal e o latão que proporcionam uma relação de transparência "desmanchada" pela sobreposição do vidro, que com a incorporação da luz artificial gera um efeito multiplicador. As peças estão instaladas na sala de jantar (a maior delas), no vestíbulo de acesso à área íntima e na sala de estar contígua à lareira e ao bar.

Pode-se dizer que essas duas peças (localizadas na sala de jantar e no vestíbulo), de alguma forma apresentam um mesmo princípio, não de um ponto de vista da sua tecnologia ou dos aspectos próprios do design deste tipo de artefato - o que não é o objeto específico desta pesquisa - mas como também se integram ao espaço proposto e contribuem, mesmo quando não acionadas, para a integridade do projeto. Elas não são obstáculos visuais, pois exatamente aonde se encontram, as vistas são fundamentais de cima à baixo (principalmente na sala de jantar) e através da transparência conferida pelo vidro, essas vistas não se perdem.

Também conferem uma linguagem moderna, refletida no uso do aço e do cristal, que resumem, ainda que representativas de algo menor, e, portanto, negligenciadas muitas vezes das reflexões sobre arquitetura, o exato alinhamento ideológico enquanto partido arquitetônico. Assim, nas contribuições de Tenreiro para a casa, há a exata compreensão e mais uma vez se manifesta o diálogo afinado com o projeto de Libeskind, pois compreende as "duas faces" dessa arquitetura - conectada ao que é próprio do lugar (as madeiras, e a expressão nacional) com a linguagem internacional.

Ainda pertence ao conjunto do mobiliário da casa duas poltronas "mole" (sala de estar com pé direito duplo) com estrutura em madeira de lei maciça torneada, com travessas que permitem a passagem de percintas em couro sola que sustentam os almofadões do assento, do encosto e dos braços, unidos numa só peça, de autoria de Sergio Rodrigues, de 1957.

Segundo Santos, o trabalho mais significativo desse momento histórico foi o do arquiteto e designer carioca Sergio Roberto dos Santos Rodrigues. "Sergio foi um homem de vanguarda cuja produção, em meados dos anos 1950, antecipou as principais propostas do nacionalismo no móvel. " (...) A proposta estética da mobília por ele criada antecipou exemplarmente os principais temas e tendências do móvel brasileiro, ocorrido nos anos 1960, sendo um elemento fundamental para a compreensão da produção desse período".10 
Há no tratamento dos pisos das salas de estar e de (alguns) elementos estruturais, como os pilares da sala de estar, guarda-corpos da escada, guarda-corpo da sala de jantar, fechamento de alguns armários, divisória do escritório, portas com trabalhos de entalhamento (acesso principal e acesso para área íntima) que prezam pela utilização da madeira como tradição de um saber e de uma técnica e riqueza desse patrimônio acumulado por mais de quatrocentos anos e do esmero da mão de obra, associados à generosidade de nossa flora que também iriam reverberar no estabelecimento de uma verdadeira tradição do móvel em madeira no Brasil, que, ainda segundo Santos, voltaria a emergir, com muita força, na obra de alguns designers do século XX, particularmente com a produção do próprio Joaquim Tenreiro (1906-1992), José Zanine Caldas (1919-2001), Sergio Rodrigues (1927-2014), Maurício Azeredo (1948-) e Carlos Motta (1952-).

No âmbito do design produziu-se, em certos momentos de plenitude criadora, um móvel com formas originais, mais condizente com nossas condições e expressivo caráter brasileiro.

A "Cadeira de Três Pés" (1947) de Tenreiro - imbuia, pau-marfim, jacarandá, roxinho e mogno - é o exemplo mais próximo desta vertente de uma materialidade brasileira de um conteúdo nacional. Mas a questão a ser destacada aqui neste trabalho é a de uma "leveza" e de uma "tradição de rigor" do desenho moderno funcionalista - menos matéria e mais performance estrutural dos componentes - integrado à expressiva materialidade brasileira. Tenreiro falava em fazer móveis mais "graciosos", aludindo àquelas peças bem torneadas e leves das suas poltronas e cadeiras, caso do mobiliário presente na casa de Libeskind descrito acima.

Este rigor presente no desenho apurado e sem excessos do mobiliário de Tenreiro, portador de uma expressividade suave, estabelece a conexão com a arquitetura de Libeskind, também afluente de uma plasticidade comedida, do apuro no detalhe, do apreço com a estrutura sem excessos, vigorosa e plácida. É possível ainda afirmar que ambas as manifestações estão conectadas com o terceiro personagem destacado para este trabalho, Alberto da Veiga Guignard, e o seu processo do ensino da pintura em Belo Horizonte, decisivo para a formação do jovem Libeskind, com o seu traço preciso, estruturado num grafismo de origem arquitetônica.

Ainda em relação ao móvel no Brasil, para Artigas, por exemplo, o que importava era recuperar o afeto especial que o homem brasileiro sempre teve pela madeira, redescobrir a origem nos nomes das essências vegetais e das diversas madeiras. Dizia que "só assim sairemos de nossas raízes, partiremos 
para o plano universal da forma moderna e, depois, reencontraremos na nossa

própria terra os principais elementos que compõe o passado de nosso gosto". Dessa maneira, concluiu ele, "[...] a consciência do colonizado flui sob o pé do colonizador". ${ }^{11}$

Segundo Santos, "trata-se de um processo mais abrangente de racionalização da arte, que obedece a certa lógica sistêmica, uma espécie de Zeitgeist - espirito de época - que faz com que tanto a arquitetura quanto a pintura ou a produção de objetos de uso apresentem a mesma sintaxe. Assim, por exemplo, ela vem associada entre nós ao triunfo da arte abstrata. Dessa forma, o mobiliário é produzido dentro do mesmo espírito que preside as demais artes. Ele é expressão de seu tempo e liga-se, de alguma maneira, às correntes estéticas em vigor."

A opção de Libeskind pelo conjunto de obras de arte - pintura e escultura, mobiliário, peças de iluminação - em consonância com a arquitetura (espaço) está inserida neste contexto ou espírito de um tempo e reúne o todo que significa a arquitetura, ideia de obra de arte total.

Mas é também uma forma de construção do seu próprio legado artístico, porque a eleição daquelas obras consiste em uma forma de autorrepresentação, daí fazer sentido uma autobiografia do autor em forma de casa habitada.

Compreendendo a construção do espaço que prescinde da hierarquia colocada entre arquitetura e peças de decoração - como itens de menor importância, Walter Gropius afirmou em 1923, que "arte e técnica são uma e mesma coisa", e isso representou, na época, uma mudança importante na maneira de encarar a produção dos objetos de uso doméstico, onde até então prevalecia a oposição entre objetos utilitários e objetos decorativos.

Para Libeskind, o mobiliário e os arranjos internos que se organizavam com telas e esculturas - objetos não apenas afetivos, mas sobretudo representantes do testemunho artístico e da manifestação estética - deveriam condizer com a pujança da revolução arquitetônica moderna, que certamente não era apenas externa. Citando Benjamin, "Para o homem privado o interior representa o universo. Reúne nele o longínquo e o passado. Sua sala é a plateia no teatro do mundo."12

Há uma cenografia, um apelo visual que se manifesta nesse arranjo. E há um ator para este palco, o arquiteto metropolitano. Neste teatro, Libeskind cria seu próprio mundo circundado pelas presenças visuais e afetivas de seus TOS. p. 103 
pares de construção ideal de um tempo artístico. A casa se relaciona intimamente com este homem, sua configuração depende da situação e do modo de vida deste seu habitante; e quando este lhe imprime seu caráter próprio e pessoal, a casa assume uma dimensão vital: a dimensão simbólica.

Ainda refletindo sobre essa casa habitada, percebe-se a aproximação significativa do processo de projeto de Libeskind com a busca pela construção de uma ambiência moderna. Isso o coloca num lugar muito próprio no cenário da produção moderna brasileira pela qualidade específica referente ao caráter dessa arquitetura. A partir das referências de projeto explicitadas por Libeskind: Frank Lloyd Wright e Richard Neutra é possível afirmar que - de forma circunscrita ao que se pretende enquanto análise para este trabalho - ambas as referências estão presentes na sua obra, sintetizadas de forma distinta na sua casa, e auxiliam na compreensão dos aspectos espaciais e construtivos da sua arquitetura, mas, sobretudo, na identificação do território cultural, simbólico e ideológico de atuação do arquiteto.

No primeiro caso, Frank Lloyd Wright (1869 - 1959), como o representante de uma vertente que preserva, com muito zelo, a condição autoral da arquitetura, não afeito às ideias de padronização ou de internacionalização, defensor de francos compromissos com o lugar e do diálogo com a cultura local. Assim, por exemplo, com uma postura alternativa à estandardização do mobiliário moderno, vai procurar expressar sua visão de obra de arte total - "Gesamtkunstwerk"- num processo de criação de uma totalidade projetual, muito bem expresso pela sintaxe das Casas da Pradaria. Neste caso, o ornamento é parte constitutiva da ação que integra a arquitetura a cada pormenor. Cada parte que se relaciona com o todo é fruto de um esmero pelo detalhe, explorado nas possibilidades de reconhecer no desenho um meio de expressão pessoal. Portanto, não cabe neste processo a obra feita a várias mãos, na medida em que o controle das intenções daquilo que se pretende está garantido. Assim, espaço e ambiente (composto por todo o mobiliário e demais elementos configuradores do espaço construído) estão absolutamente associados no domínio da criação do espírito puro, cujo objetivo é provocar emoções plásticas de acordo com a expressão do seu criador, que retoma, segundo Frampton ${ }^{13}$, a ideia de transformação da técnica industrial por meio da arte.

Em Wright também é possível localizar a opção de Libeskind pelo acerto com o lugar, que, segundo Montaner ${ }^{14}$ modela o espaço, a partir do progra1997.p. 61 
ma funcional, utilizando materiais tradicionais. Ainda, segundo o autor, é, de

fato, "no espaço aberto e extenso que Wright descobre mediante a destruição da caixa compartimentada convencional (que) já está presente a concepção específica do lugar". Há também a opção por uma quase absoluta ausência de paredes divisórias e uma enorme coerência da geometria - isso inclui os objetos e móveis, que reforçam a presença de "paredes de ar"15 entre os espaços intersticiais que se conectam.

Nesse sentido, está presente na arquitetura de Libeskind a lição aprendida de Wright dos planos horizontais contínuos e muros limítrofes (muitas vezes baixos) de expressão monolítica com impressões de blocos têxteis, ${ }^{16}$ em fortes contrastes com os volumes internos de pés-direitos duplos que se abrem para o exterior. ${ }^{17}$

Segundo Argan, para Wright, o edifício com relações de verticais e horizontais, de planos e volumes, ressalta as linhas estruturais do local, dá-Ihes precisão: é "esse determinado local", mas reestruturado pelo homem para torná-lo um local da vida, onde o processo tradicional da concepção arquitetônica não parte mais do exterior, e sim do interior, do local desta vida abrigada.

A lareira também representa um outro elemento significativo para Libeskind em associação com Wright - afora toda a reflexão já realizada sobre o tema do elemento fixo em espaços fluídos - pois o arquiteto a trata como um elemento extraordinário, único e irreproduzível, ou seja, não a replica de forma padronizada em sucessivos projetos, mas, ao modo de Wright, desenha para cada casa, como na sua própria residência e nas residências Antonio Mauricio da Rocha, Germinal Ortiz Garcia e Natan Faerman, um elemento que marca o desejo, a partir da franca revelação da sua alvenaria e da chaminé como "a expressão de um abrigo, enfatizada como única substância sólida desejável num interior de crescente fluidez".18

Para Libeskind esse volume também é, via de regra, objeto de exploração plástica e material, o que revela seu protagonismo e importância.

2ª. ed. rev. e ampl. São Paulo: Editorial G. Gili, 2012. p. 35

15 COHEN, Jean-Louis. O futuro da arquitetura desde 1889: Uma história mundial. São Paulo: Cosac Naify, 2013. p. 62

16 Ibidem, p. 224. Expressão utilizada pelo autor a partir de Henry-Russel Hitchcock, referindo-se aos "textile bloks", moldados em cimento e montados com hastes de aço, que Wright empregou entre 1923 e 1924 nas casas Ennis, Storer, Freeman e Millard - um reflexo do encontro com o ambiente acolhedor da Califórnia.

17 FRAMPTON, 1997, p. 226. Wright também foi, segundo o autor, subitamente possuído pelas qualidades expressivas do vidro, cuja transparência cristalina podia ser mais bem complementada pelos atributos liberadores da planta livre de colunas. 
A contribuição definitiva de Wright para a obra de Libeskind talvez repouse no fato de que "o estilo do artista pode ser considerado como um conjunto de elementos típicos organizados em conjuntos completos que, por si só, assumem padrões genéricos e característicos. Um estilo baseado em um princípio que incorporará uma espécie de "sistema" de formas construtivas que se combinam e recombinam de acordo com regras gramaticais e intuitivas. Tal "fórmula" é o oposto de um "clichê" repetitivo e pobre, ela é uma abstração que permite muitas possibilidades criativas a partir de alguns poucos temas centrais". ${ }^{19}$

Esta contribuição torna-se evidente através das sucessivas experimentações particulares de Libeskind nos seus projetos que os considerava ensaios sobre a totalidade espacial percebida, sem uma demarcação clara do lugar específico da arte ou da arquitetura, porque estas estão sempre em fusão. Por isso é possível afirmar que "cada nova tarefa de construção é mais uma oportunidade para explorar o tipo ideal e, ao mesmo tempo, descobrir novos significados". ${ }^{20}$

No segundo caso, Richard Neutra (1892-1970) - que irá trabalhar para Wright, em 1925, em Los Angeles, após já ter trabalhado para ele por dois anos em Chicago - como um destacado representante da ambiência moderna, assimilando o mobiliário, ${ }^{21}$ com linhas afinadas com a sua arquitetura, incorporado ao espaço por ele projetado, tomando para si as prerrogativas de um projeto para construção seriada, no desenvolvimento e na produção dos componentes arquitetônicos, ainda que vinculadas às questões imanentes de uma região.

As transparências possibilitam o franco diálogo entre interior e exterior como forma da integração visual total, completa, ininterrupta. Neste caso o léxico moderno está posto, uma vez que um conjunto de elementos originários de uma mesma matriz ideológica se constitui para garantir o máximo propósito desta arquitetura. O esquema compositivo fundamental das plantas de Neutra - que irão influenciar definitivamente o processo de projeto de residências de Libeskind - se resume, segundo Cohen ${ }^{22}$, no emprego de um volume longitudinal relativamente simples e aberto de um só lado que pode ser acoplado com texto de casas particulares, como cadeiras, sofás, mesas e luminárias, e em todos esses casos essas peças expressavam o espírito da sua época. Exemplo da cadeira Cantilever, de 1929, desenhada para a Casa Lovell; a versão em madeira para a Casa Branch, de 1924 e com encosto mais alto para a Casa Tremaine, de 1947.

22 COHEN, 2013. p. 346 
elementos semelhantes para produzir as mais variadas disposições, e a abertura para o exterior se transforma em uma porosidade quase total.

A arquitetura de Neutra representa o aço preciso, o vidro laminado, a transparência e a iluminação, "onde os planos minimalistas e flutuantes do Estilo Internacional recebiam uma expressão distinta de acordo com o clima e a topografia",23 explicitada, sobretudo, nas casas californianas.

Entende-se que a relação entre a obra de Neutra e a de Libeskind aproxima-se mais pela linguagem material e por perseguir um resultado espacial limpo, conectado, não compartimentado do que propriamente em relação à técnica construtiva com o emprego do aço como componente estrutural, elemento que foi o leitmotif do programa das Case Study Houses.

Argan ressalta a importante relação que, sob o ponto de vista histórico, no século XX, se estabelece entre a arquitetura europeia e os Estados Unidos. Os primeiros arquitetos europeus a escolherem os EUA, isto, é, o país tecnologicamente mais avançado, como campo de trabalho são, entre outros, Richard Neutra, aluno de Loos, em 1923 e Eero Saarinen, no mesmo ano. A conjunção entre o geometrismo racionalista e o estruturalismo orgânico, ainda segundo Argan, (principalmente em Neutra, cuja atividade na Califórnia contribuiu para a formação de uma florescente "escola californiana") colaborou para a determinação da tipologia da "casa de campo refinada."

Para compreender Wright deve-se passar pela tradição americana, sobretudo, pela Escola de Chicago, através de Louis Sullivan. Mas não apenas isso, ele expandiu seus horizontes voltando-se para o oriente, de onde recoIheu elementos fundamentais para a sua arquitetura. Neutra pertenceu a outra geração, e experimentou nos anos de sua formação a chegada de um movimento que se converteria em elemento fundamental da sua doutrina artística.

Desta forma, o que no século XIX era pura fantasia arquitetônica - inter-relação e penetração de planos verticais e horizontais, transparentes e opacos e abertura radial para a paisagem - havia se convertido, no século XX, em uma forma de vida.

Esta condição confere uma qualidade atemporal para a arquitetura, de uma elegância tranquila e que convoca um outro aspecto não menos importante, relativo à própria construção imagética desta arquitetura, tomada como exemplo a documentação do programa Case Study Houses e toda a sorte de fotografias de autoria de Julius Schulman. ${ }^{24}$ No caso específico de Libeskind,

24 Julius Shulman (10 de outubro de 1910 - 15 de julho de 2009) foi um fotógrafo de arquitetura americano mais conhecido pela sua fotografia da "Case Study House 22", do arquiteto Pierre 
assim como de todo um grupo relevante de arquitetos modernos brasileiros, a documentação das suas obras estava, na grande maioria das vezes - com exceção de algumas fotografias tiradas pelo próprio arquiteto - a cargo do respeitável fotógrafo José Moscardi. Essas imagens estavam imbuídas de um olhar revelador, bastante sensível ao espírito de uma arquitetura absolutamente vinculada à qualidade ambiental, em consonância também, fato essencial, com o processo de documentação e divulgação dela própria.

E é justamente ao se debruçar sobre esses registros que se faz possível refletir sobre a produção da arquitetura moderna brasileira, suscitando afirmar que havia um conjunto significativamente coeso, ainda que não necessariamente hegemônico, na construção deste espírito que trabalhava em consonância: a lógica cultural de uma época da qual Libeskind é um legítimo representante. ${ }^{25}$

Neste trabalho procura-se reconhecer este lugar ou o espírito de uma época, a partir de um aprofundamento e ao mesmo tempo de uma síntese, uma vez que o objeto central de análise - ponto de saída e de chegada - é a casa do arquiteto, lugar para onde converge o universo de referências concretas e vividas, abstratas ou remotas apontadas aqui. O esforço em identificar modos de operar dessa arquitetura através de recortes ou, dito de outra forma, estabelecendo quadros aproximados, tem como método a investigação pela palavra, como já explicado, mas também através da organização das imagens proposta de tal sorte a tornar possível avançar na construção de uma crítica da produção brasileira que possibilite ultrapassar os limites inerentes da historiografia, fruto do trabalho com os acervos a partir do contato com as fontes primárias ou secundárias. Nesse sentido, há um sabor ensaístico, ainda que prevaleça o rigor perseguido na tentativa de estabelecer com clareza as pontes de associação entre uma coleção significativa de personagens, lugares, tempos e referências.

Koenig, em Los Angeles, de 1960. A fotografia de Shulman divulgou a arquitetura moderna da Califórnia do meio do século XX para o mundo. A clareza do seu trabalho transformou a fotografia de arquitetura numa forma de arte independente. Cada imagem unia a percepção e a compreensão dos edifícios e da paisagem onde estavam implantados. A composição precisa revelava não apenas as ideias por trás da superfície do edifício, mas também as visões e esperanças integrais das ideias. O senso de humanidade estava sempre presente em seu trabalho, ainda que a figura humana não estivesse.

25 É patente a admiração de Oswaldo Arthur Bratke (formado no curso de engenheiros-arquitetos do Mackenzie em 1930) pela arquitetura que se desenvolveu na Costa Oeste dos Estados Unidos, sobretudo da obra de Richard Neutra e das manifestações em torno da revista de vanguarda Arts \& Architecture. Segundo Hugo Segawa, Bratke é o mais paradigmático entre os profissionais que compartilharam desses princípios, não se atendo à influência de Le Corbusier como a maioria de seus colegas de geração. 
O espírito de uma época, mas também a valorização do espírito do lugar, em Libeskind, está colocada na relação com os modos de vida e não necessariamente com uma autorreferência estética ou individualista, ou com uma abstração cultural, ou ainda com um aspecto regional de reconhecimento das culturas locais e populares.

A visão do processo racionalista do Movimento Moderno não se bastou na busca expressiva de uma nova arquitetura, de pronto absorvida pelo jovem Libeskind, e nem como resposta às grandes demandas sociais, mas no compromisso dessa arquitetura como resposta a uma vertente que não se vincularia, necessariamente, à corrente predominante de raiz "corbusiana".

Segawa ${ }^{26}$ comenta que "o contato ao vivo com Wright (que esteve no Brasil em 1933) 27 não comoveu Lucio Costa tanto quanto o proselitismo literário, a amplitude da abordagem de Le Corbusier, imbuído em espírito de transformações sociais". E nesse sentido, o autor reforça que a "linha paulista foi um conjunto de vertentes não formalmente em acordo entre si, unitário, mas examinadas em seus fundamentos, derivadas de uma saudável dialética entre as duas escolas de arquitetura (USP e Mackenzie), um ativo departamento regional do Instituto dos Arquitetos e profissionais independentes, respeitados por suas realizações" - e este último seria o caso de Libeskind, uma vez que a sua formação se deu fora do eixo Rio de Janeiro - São Paulo e não possuía vinculação acadêmica.

Ainda sobre as referências diretas e indiretas Segawa completa: "a arquitetura brasileira em geral estava atenta a determinadas discussões ou personalidades no plano internacional. A polarização entre posições "organicistas"(da linha de Frank Lloyd Wright e do proselitismo de Bruno Zevi) e "racionalistas"(Le Corbusier, Gropius, Mies) tomou boa parte dos debates até o início dos anos de 1960. Um arquiteto que inspirou muitos jovens brasileiros foi Richard Neutra, que visitou o país e foi o único arquiteto estrangeiro nesses anos que teve uma publicação bilíngue editada no Brasil (Arquitetura Social em Países de Clima Quente/ Architecture of Social Concern in Regions of Mild Climate, 1948)."

Ainda que formado em Minas Gerais, Libeskind também absorveu as influências apontadas por Segawa, que gradualmente se consolidaram a partir da sua vivência na metrópole paulista. Mas há uma certa liberdade de expresUniversidade de São Paulo, 2018. p. 81

27 Frank Lloyd Wright visita, no Rio de Janeiro, a exposição de Arquitetura Tropical, a qual reúne trabalhos de Gregori Warchavchik, Lucio Costa, Affonso Eduardo Reidy e Marcelo Roberto. 
são conquistada por Libeskind, talvez por sua condição "migrante", que permite expressar um princípio que define de maneira direta e pessoal a sua relação com o mundo. Remonta, nas palavras de Argan, à posição de Wright, "onde o contato direto do indivíduo com a realidade se lhe afigura antes como o princípio da democracia, no sentido próprio da máxima lincolniana. (...) e a casa não deve ser um espaço dado e rigidamente subdividido, que condiciona a existência; deve ser o meio de um contato com a realidade, onde cada qual realiza a si mesmo". ${ }^{28}$

A arquitetura de Libeskind é uma afirmação da cultura moderna brasileira que reivindicou a liberdade criativa para a arte; que adotou nos projetos o núcleo gerador que está recolhido a partir das relações dinâmicas e opostas entre poder da matéria construída e da transparência leve, compreendendo que o ambiente interior é o elemento essencial da vida, amparado pelos avanços da tecnologia, mas sem necessariamente se maravilhar pelas possibilidades plásticas do concreto armado ou por sua aparência bruta, ou, ainda, pela filiação a um projeto político, porque está inserido num contexto muito expressivo, ainda que equilibrado e rigoroso.

As discussões do lugar da arquitetura moderna brasileira a partir da década de 1960, justamente a partir da construção de Brasília, revelam um momento de importante revisão dos caminhos seguidos pelo Movimento Moderno e que apontavam para diferentes direções, num contexto de incertezas. Parece absolutamente saudável, nesse sentido, que Libeskind tenha procurado um caminho que pode ser considerado próprio, a partir das interpretações pessoais das referências internacionais. Isso não é afirmar um racionalismo nacionalizado, ou um regionalismo, mas apontar que as suas experiências estavam em sintonia com o que se revelou, a partir da crítica externa, nos anos 1940, como uma recepção que "valorizava na experiência brasileira a capacidade de adaptação dos princípios formulados na Europa e nos Estados Unidos às peculiaridades climáticas, técnicas e culturais do país. Boa parte se constituiu a partir de interpretações sofisticadas das manifestações internacionais, e gerou surpresa e reconhecimento favorável por parte da crítica estrangeira. (...) Os arquitetos brasileiros demonstravam em suas obras um entendimento adequado das premissas modernas de que o novo deveria necessariamente se constituir como uma crítica do passado. (...) era perceptível no Brasil uma resistência à um modelo único."29 
Assim sendo, Libeskind colaborou com a ampliação dos horizontes da linguagem da arquitetura moderna brasileira, apresentando-nos a sua compreensão do lugar do projeto. 


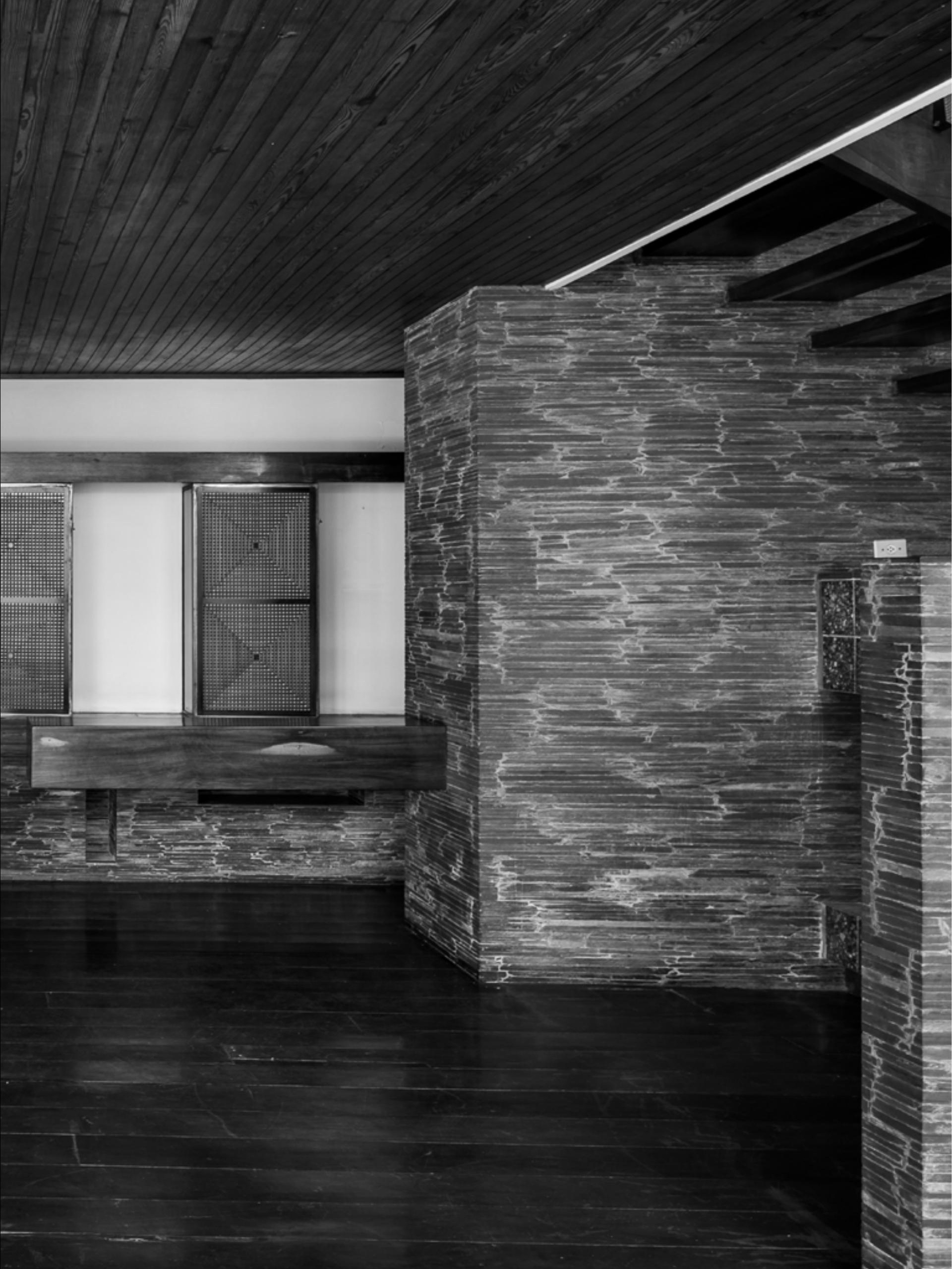



TERCEIRO ATO: ARQUITETURA EM TRÂNSITO 


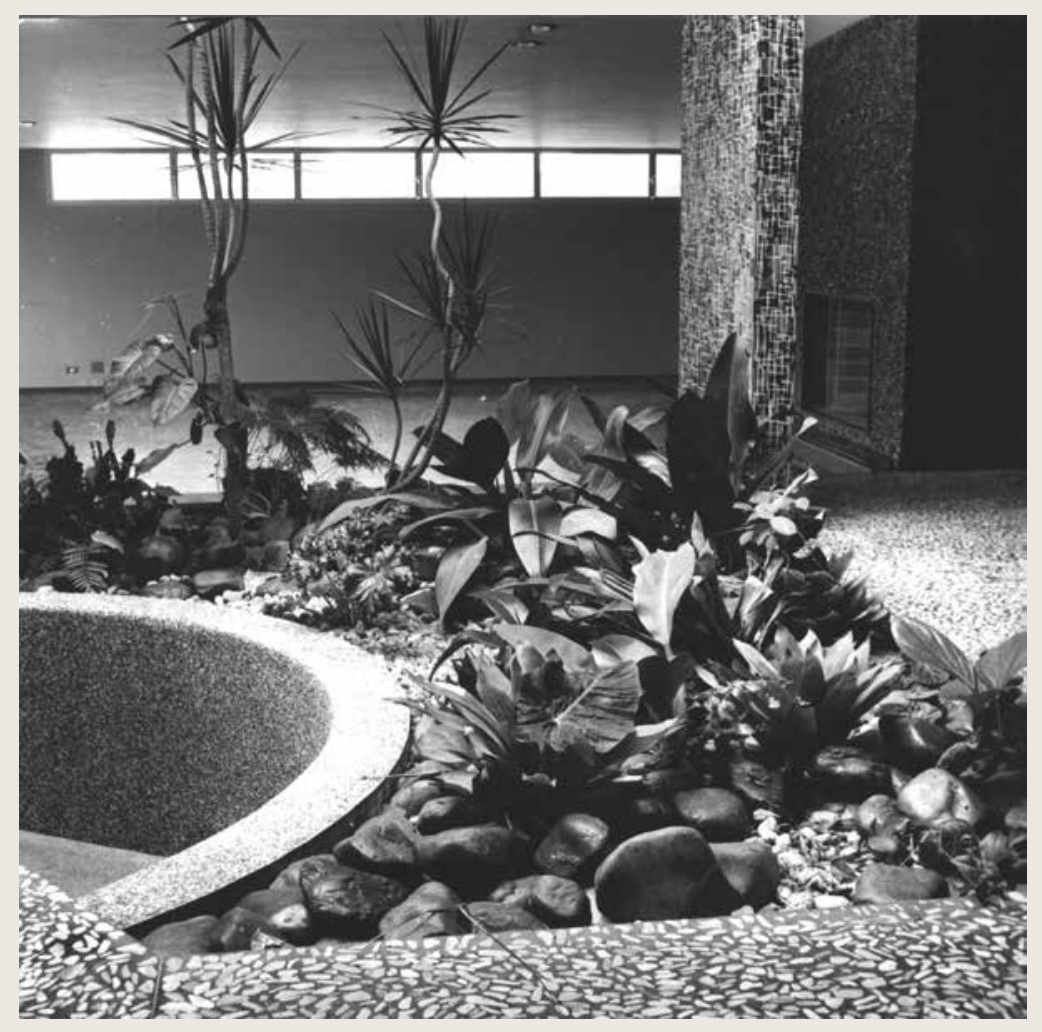




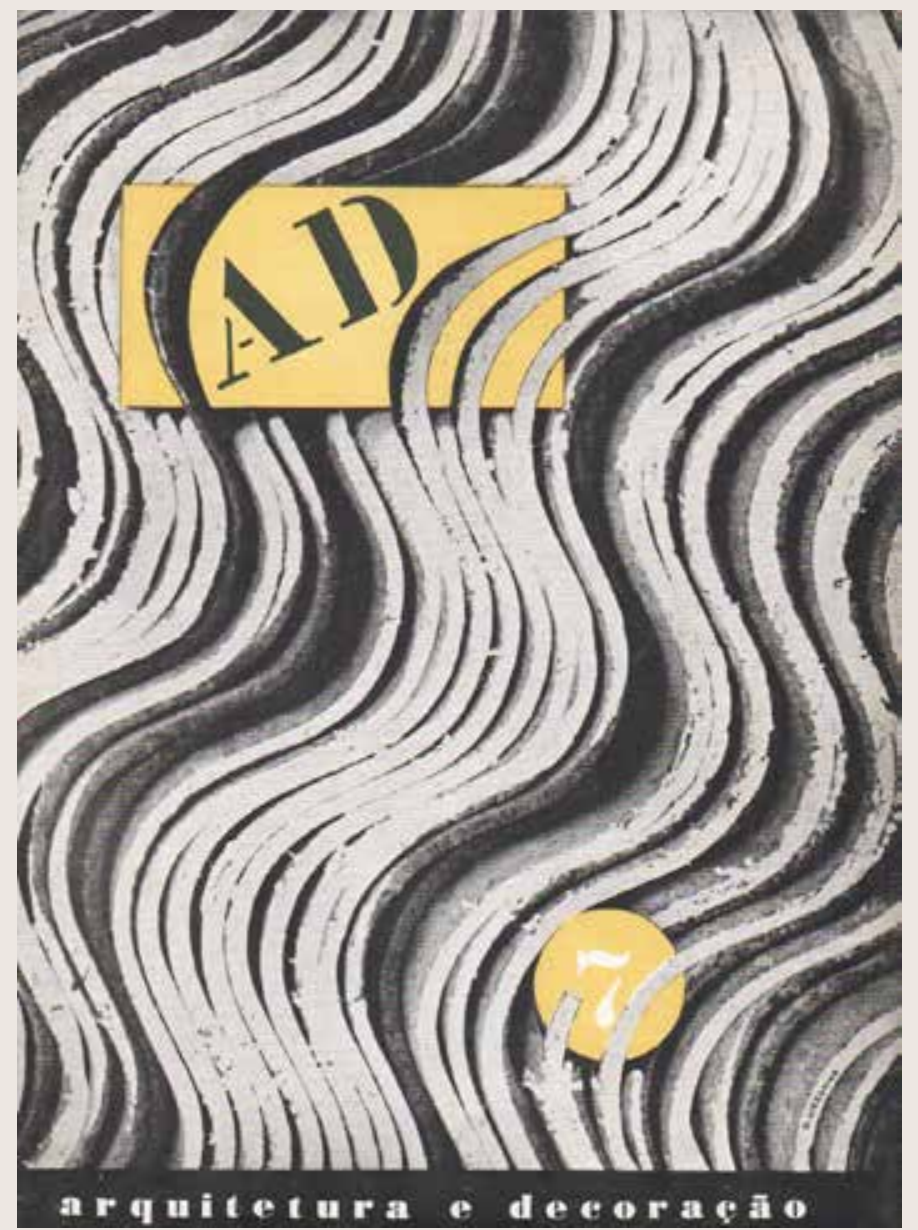


66
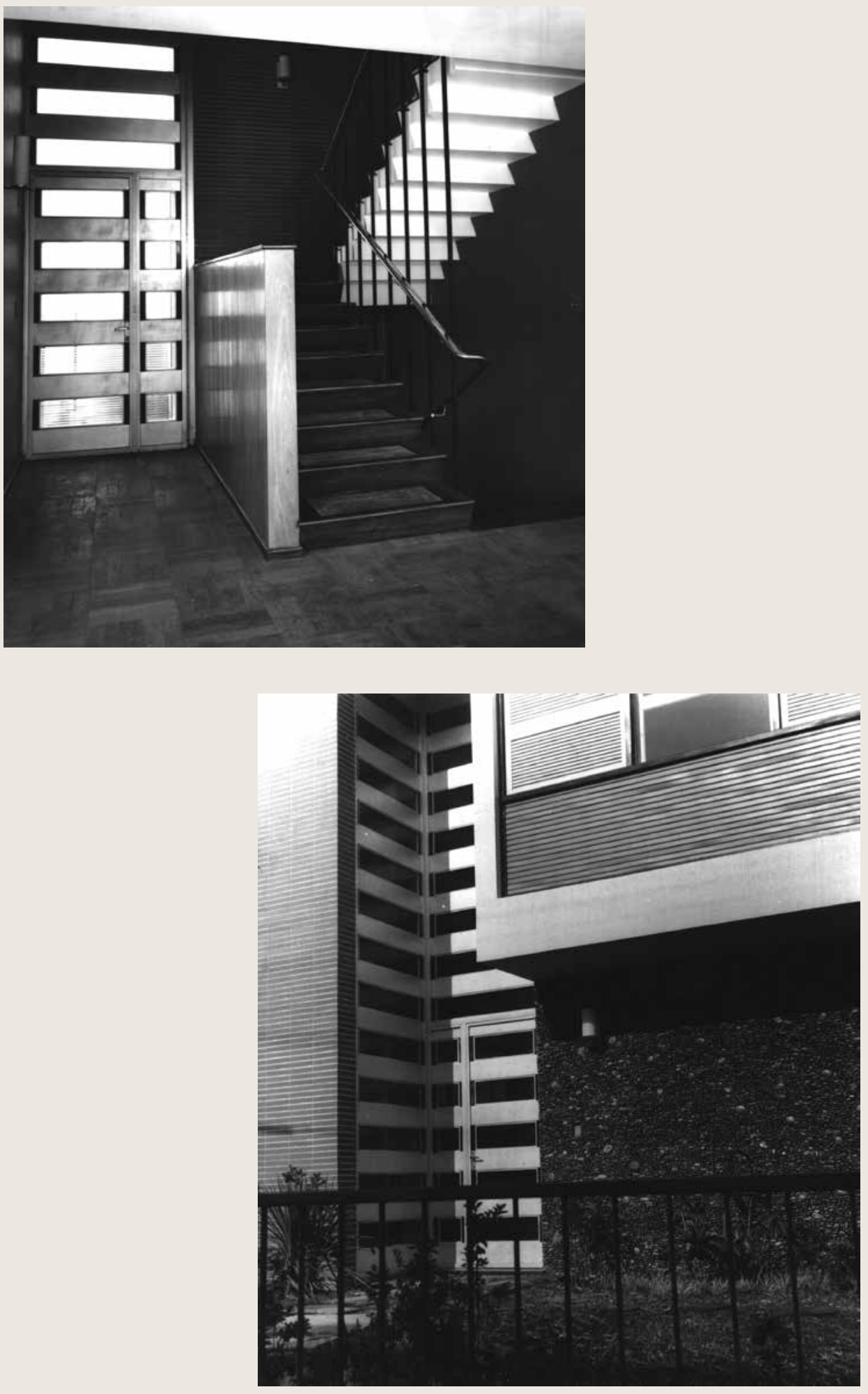

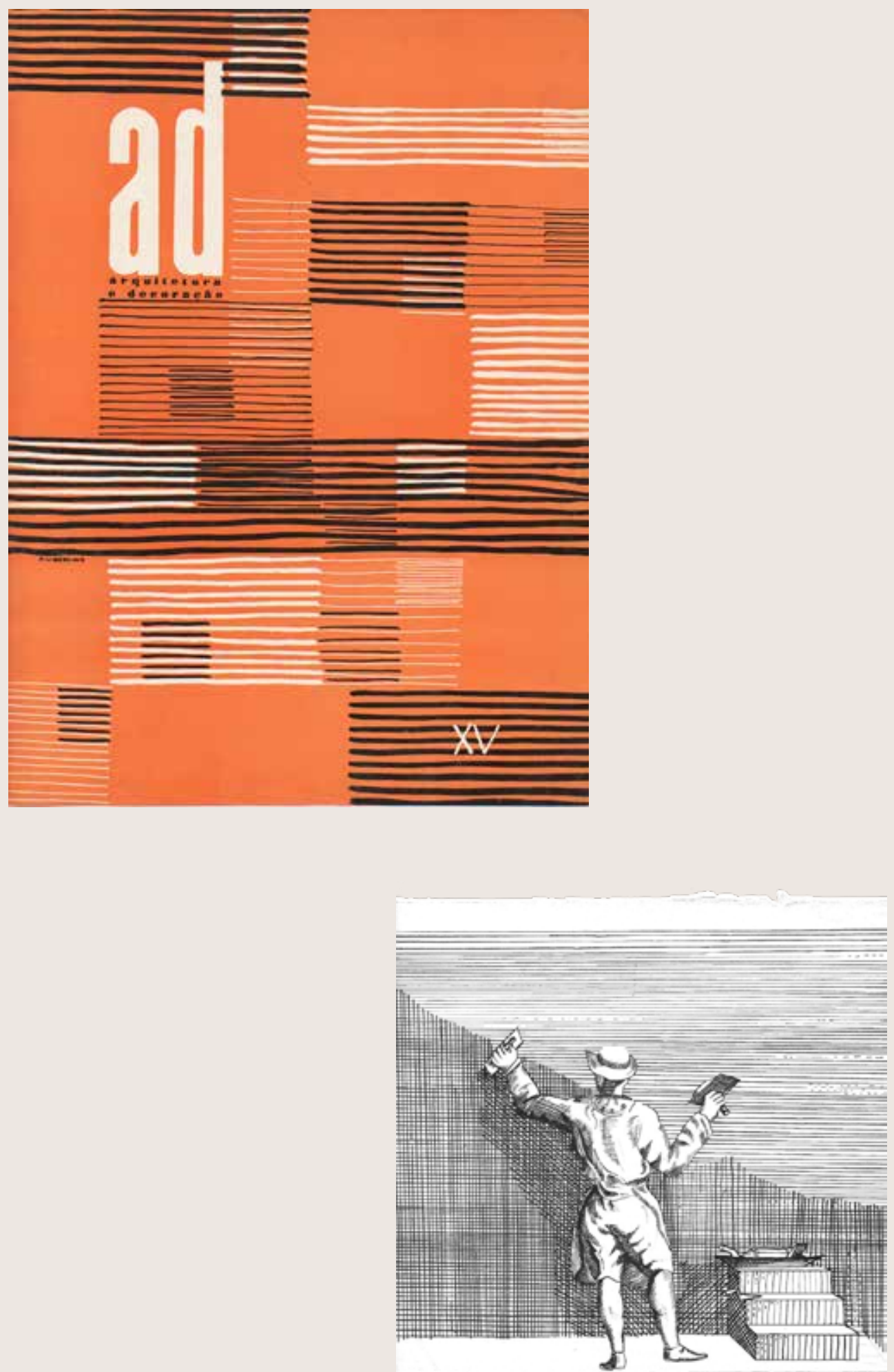

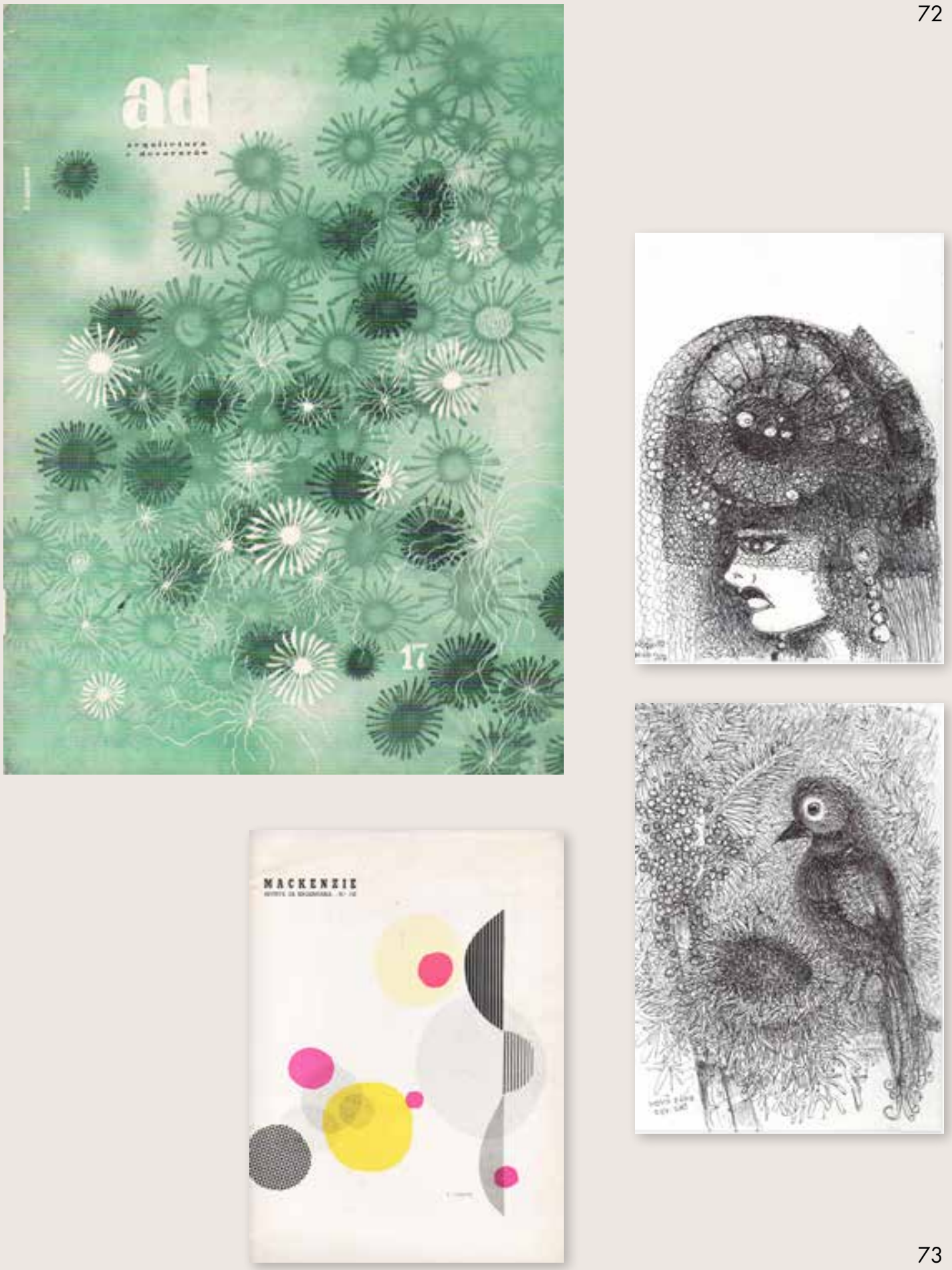

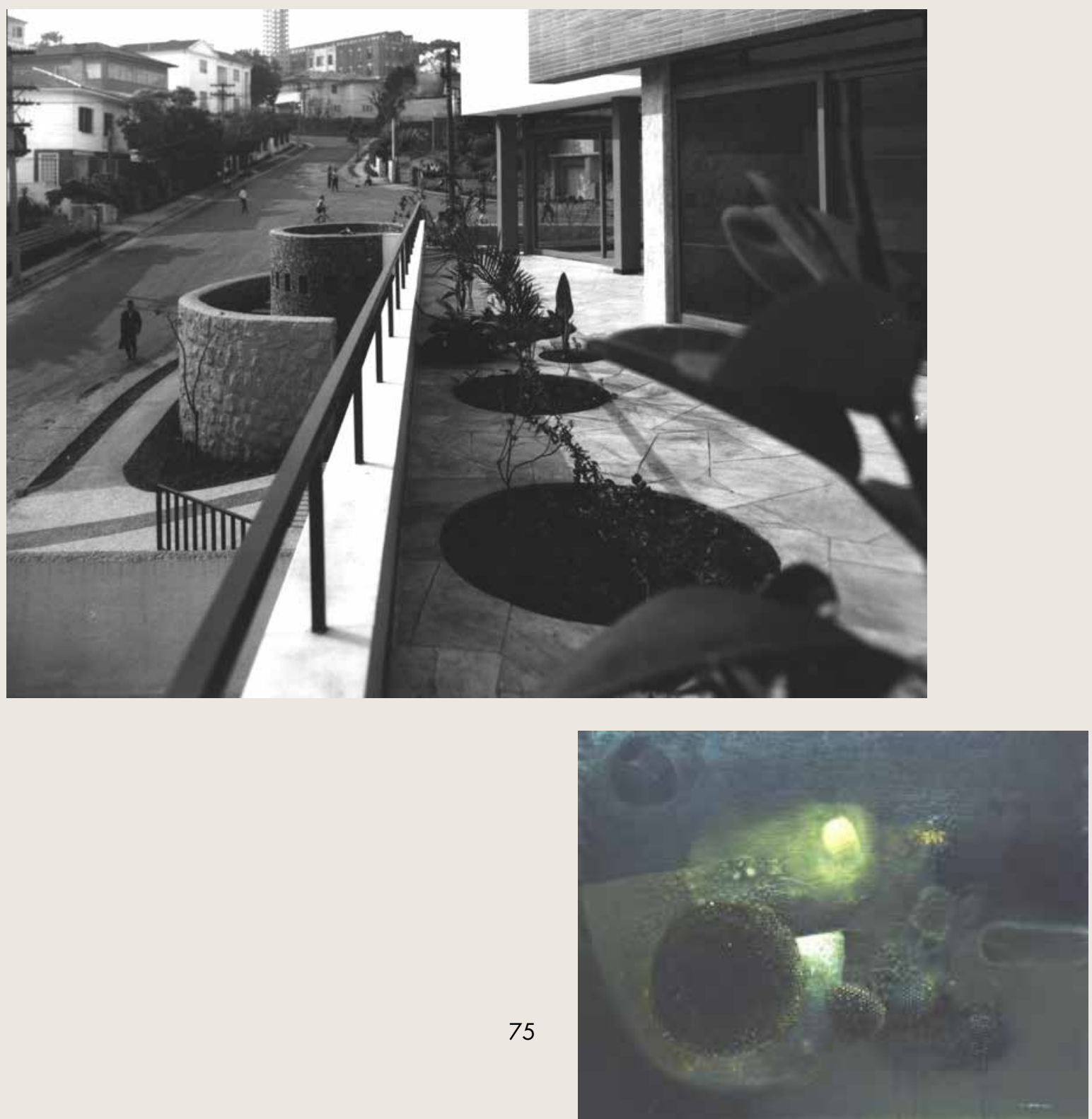

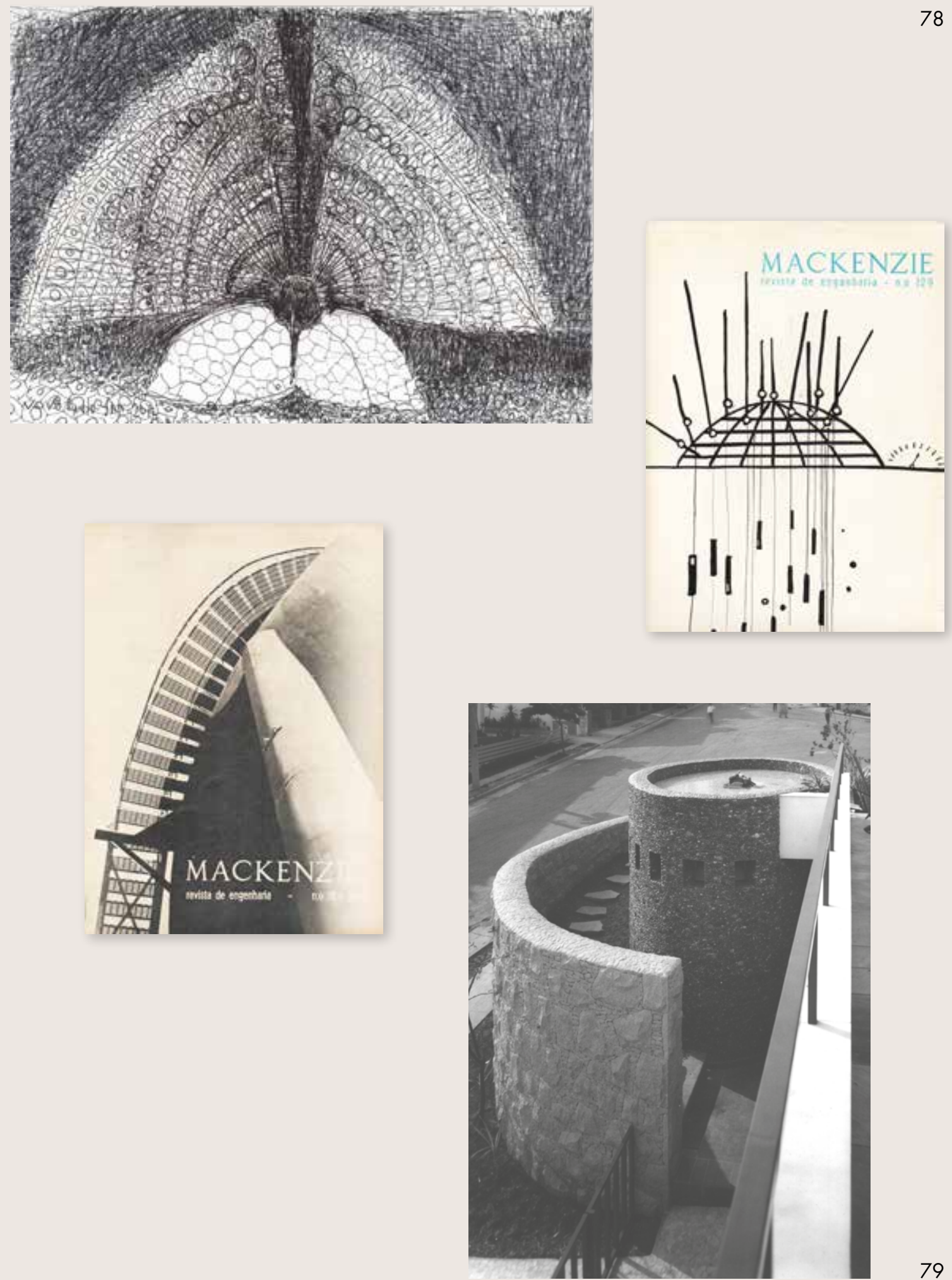

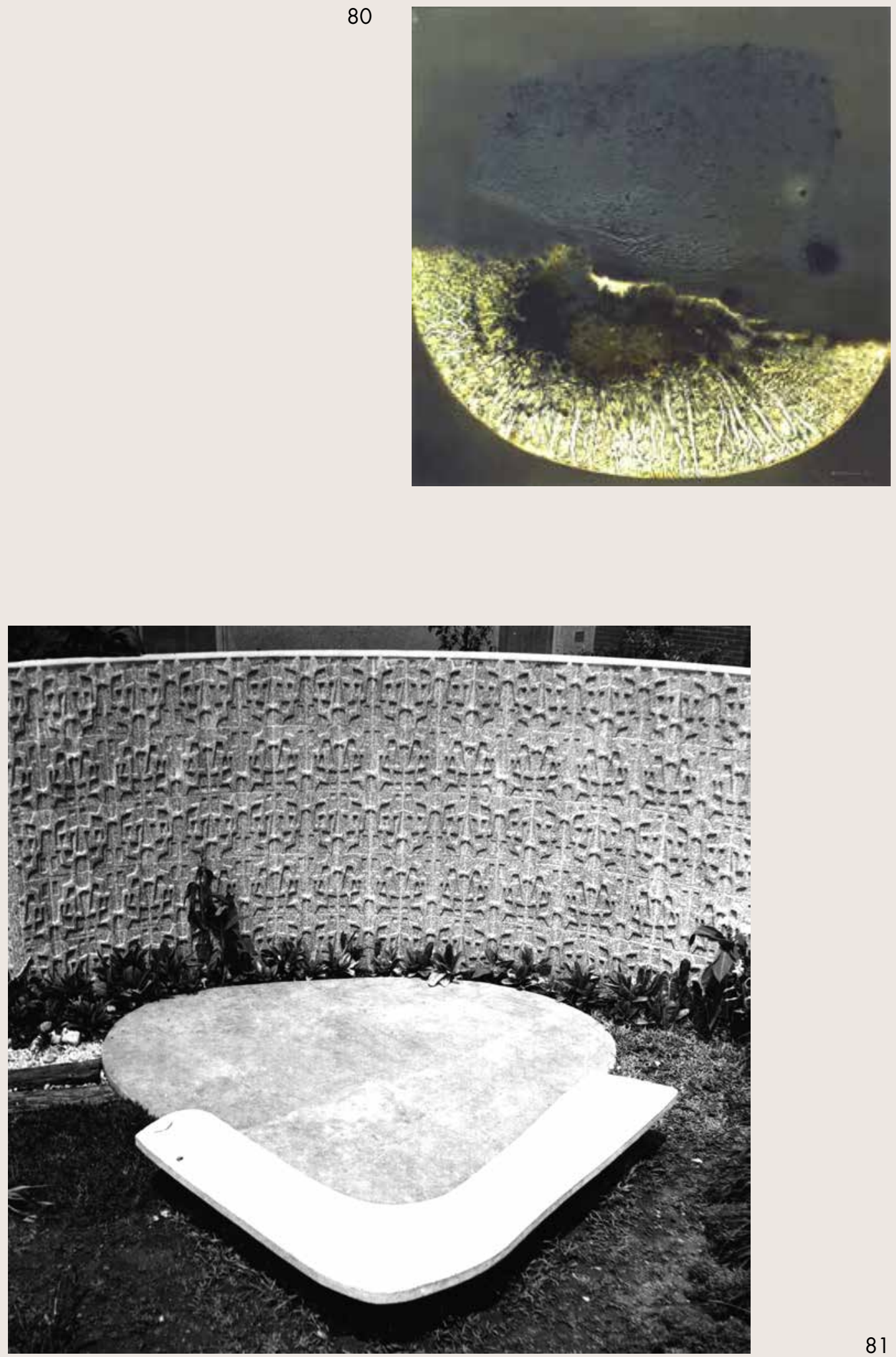

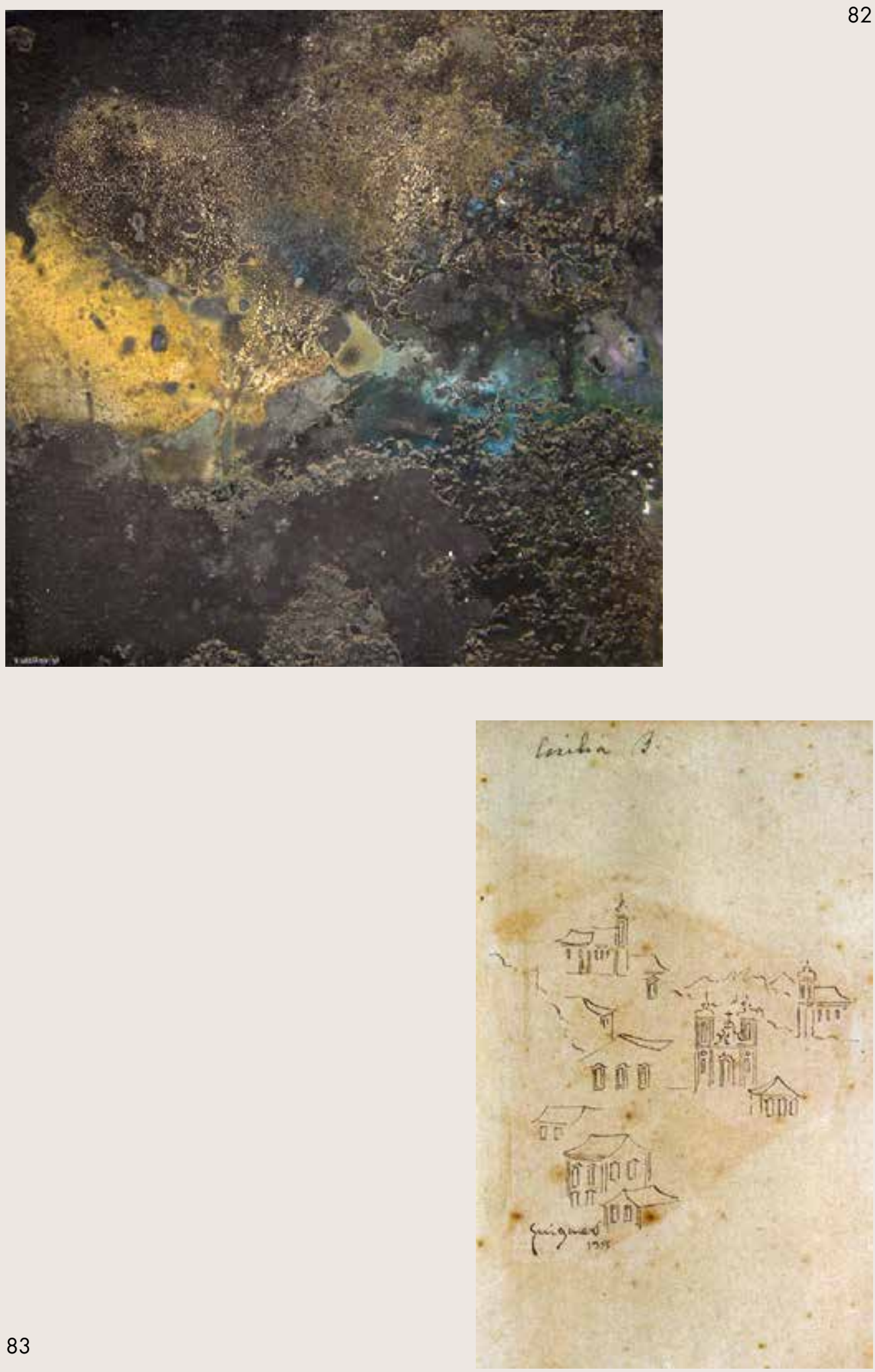

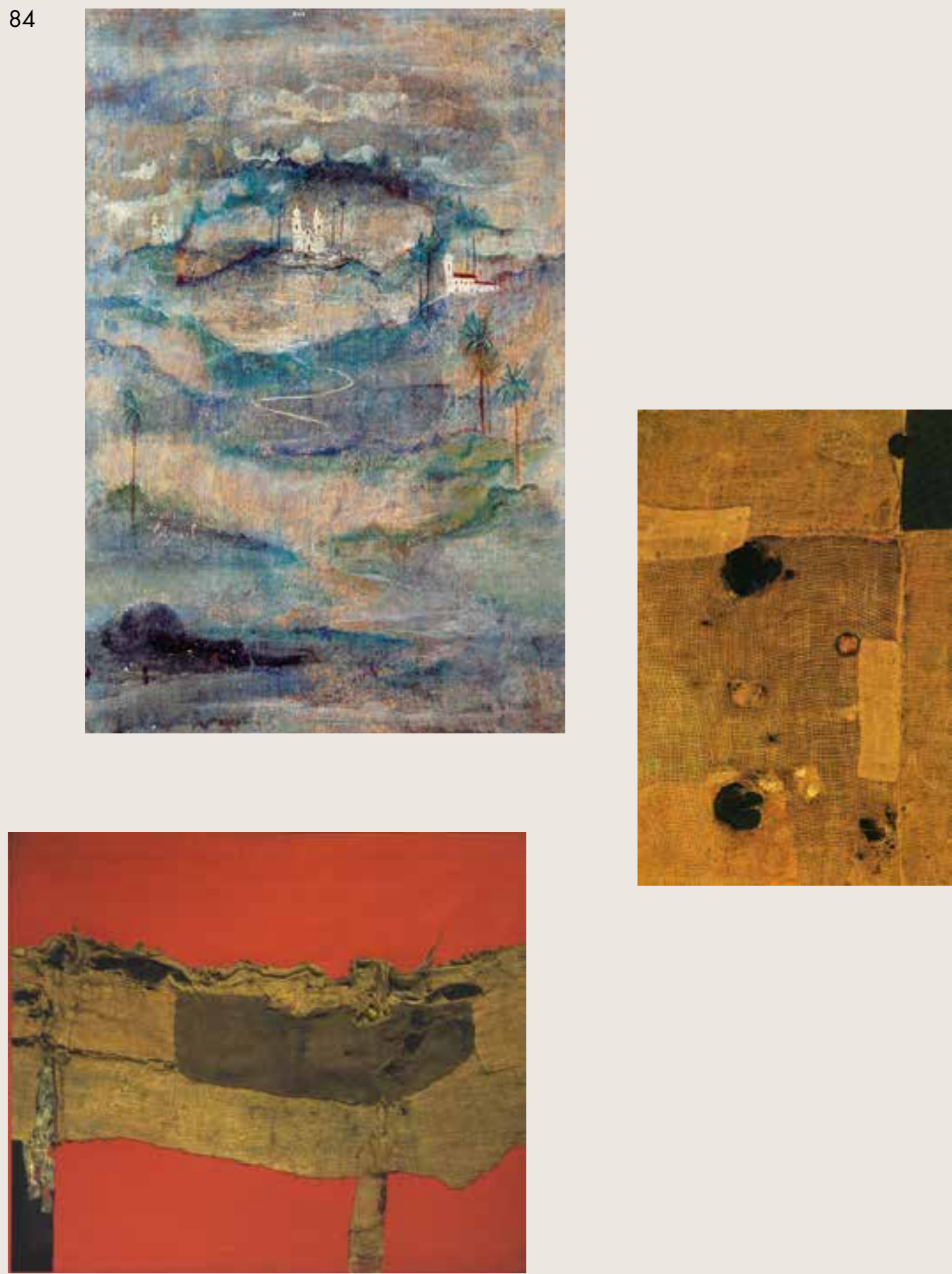

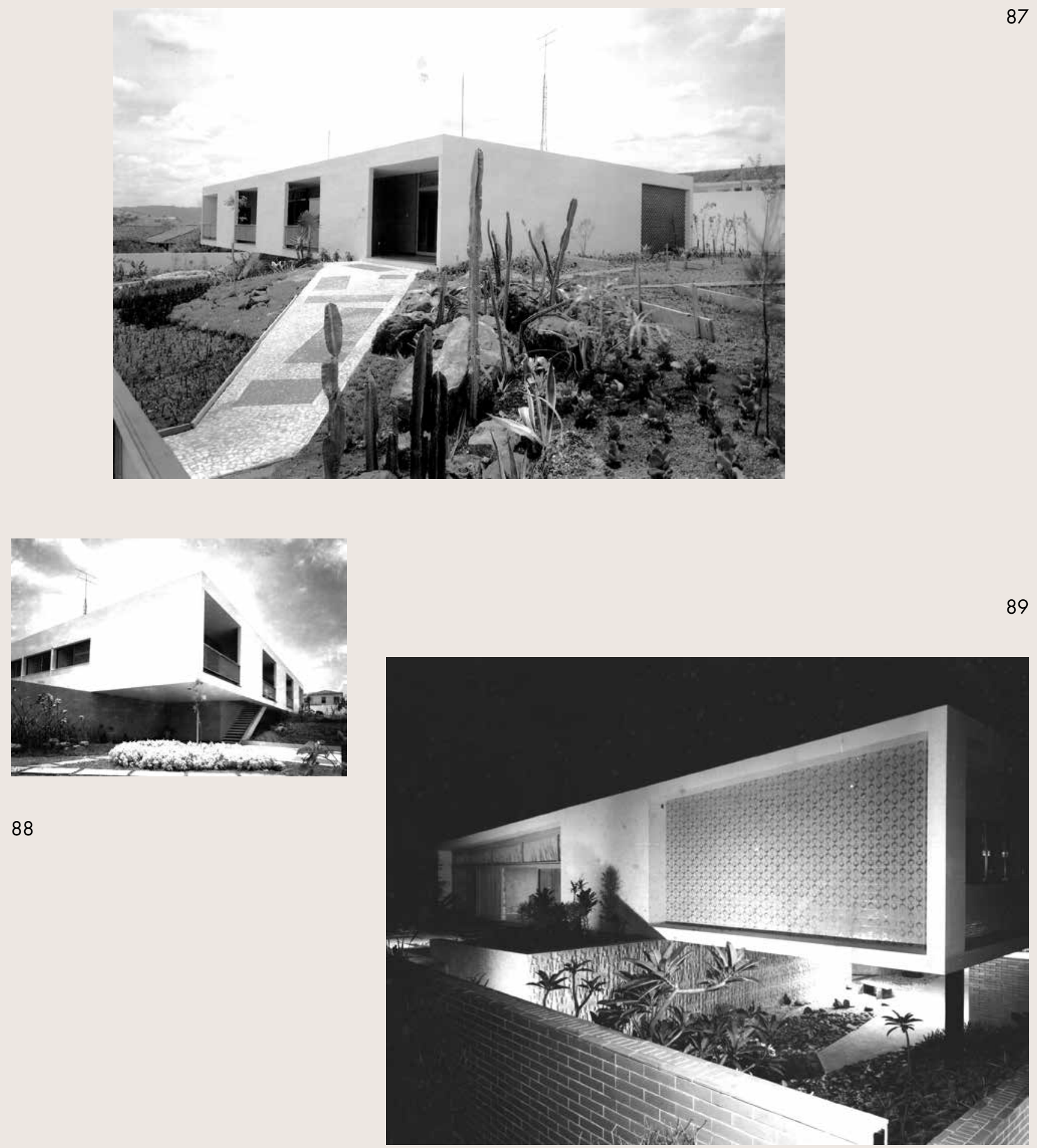


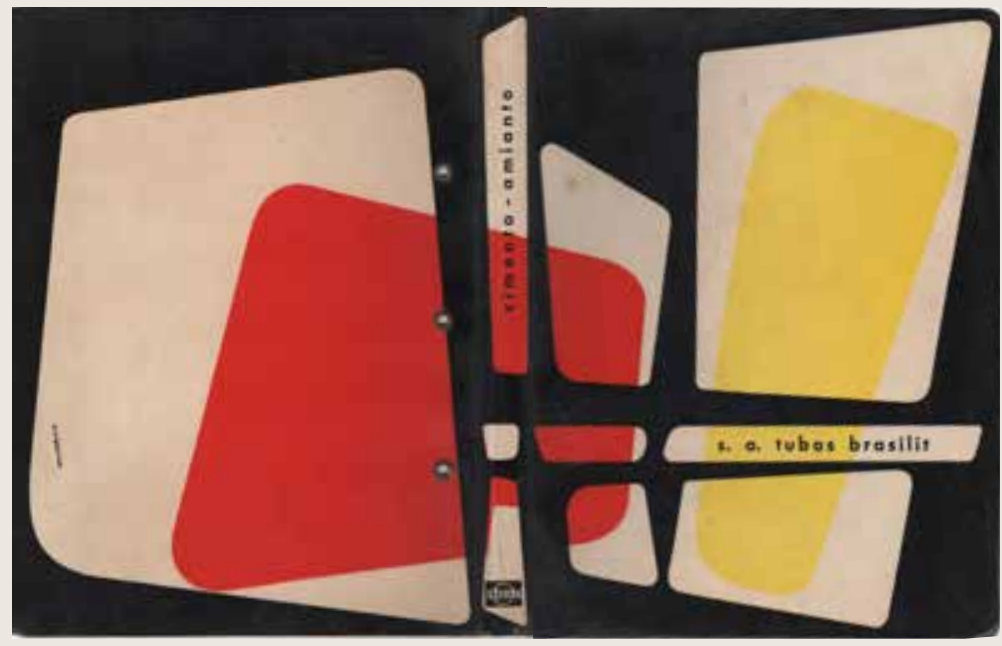




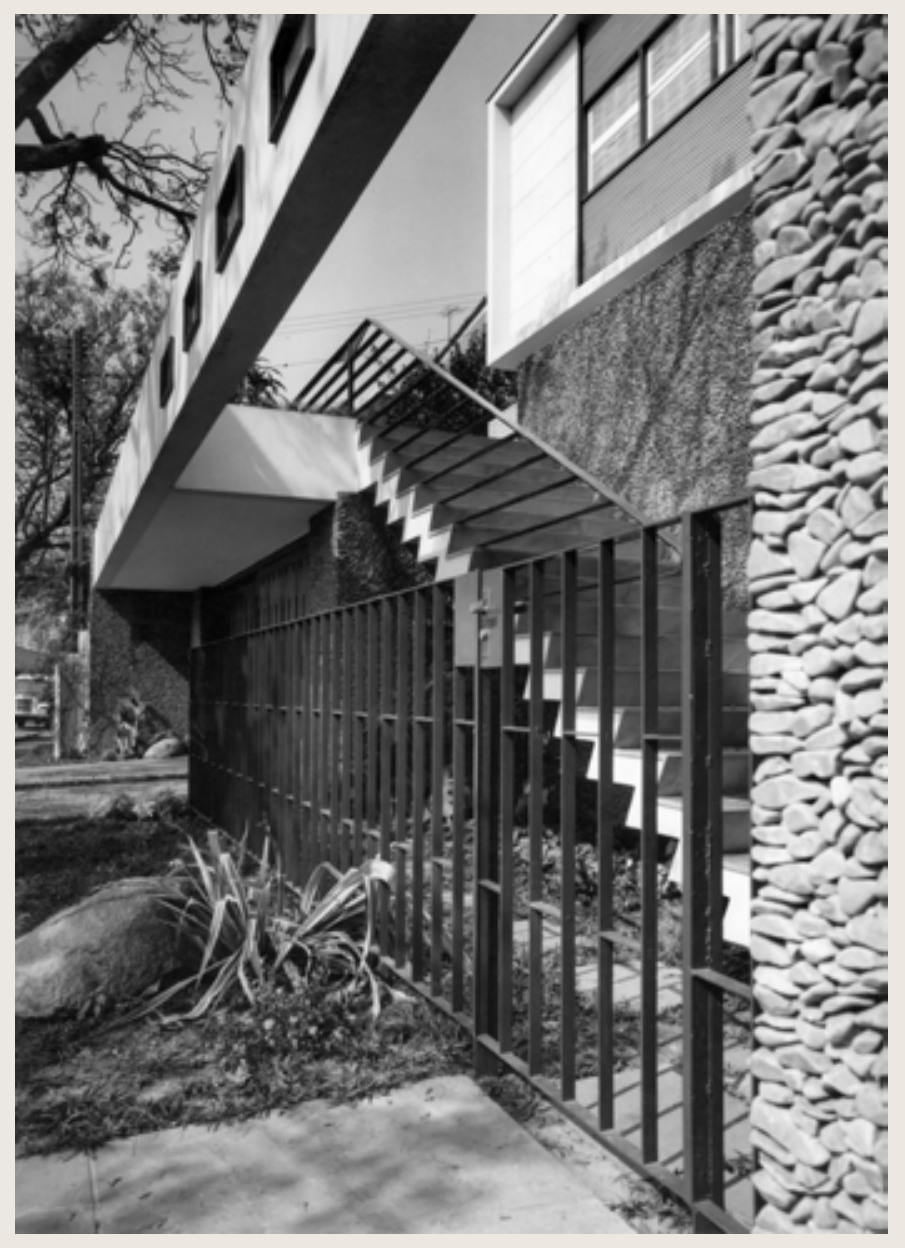



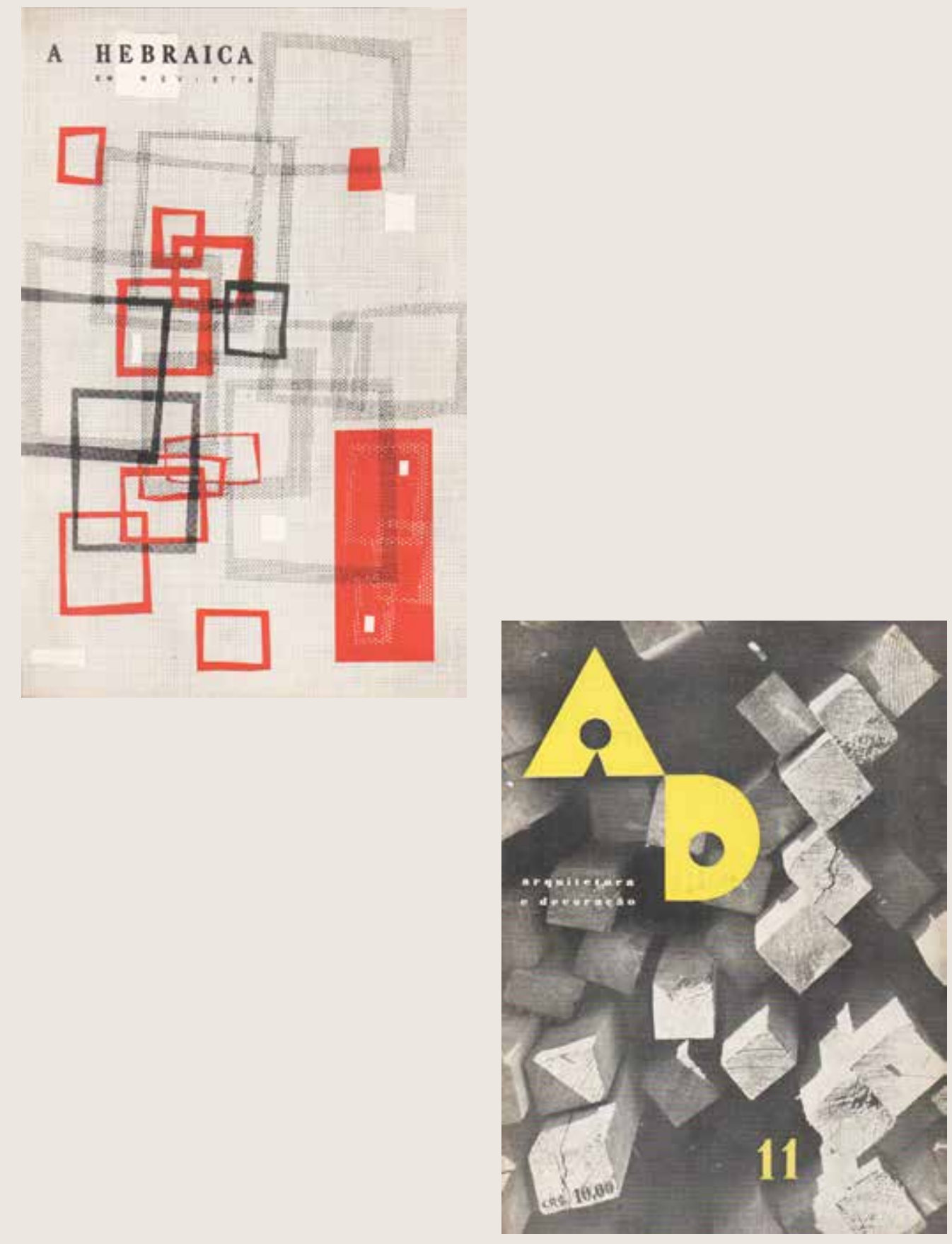


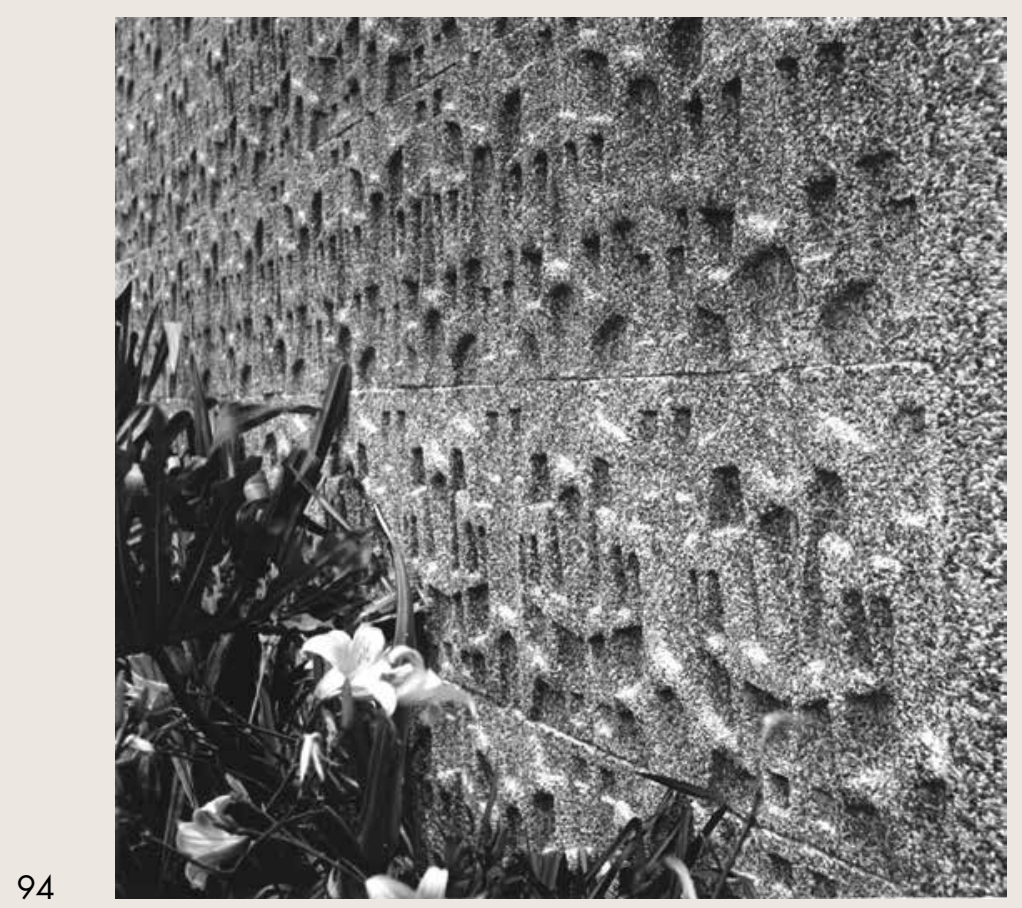



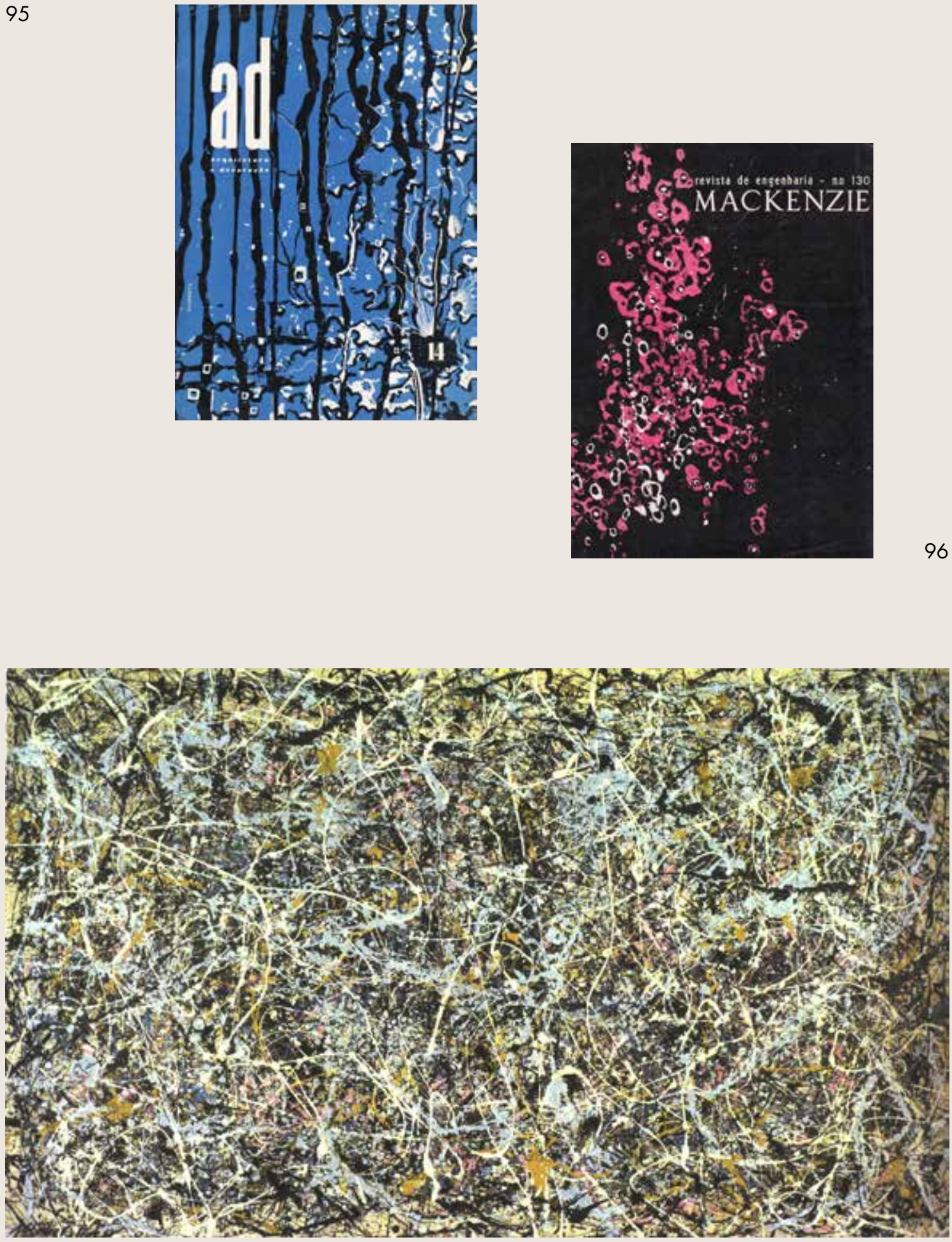


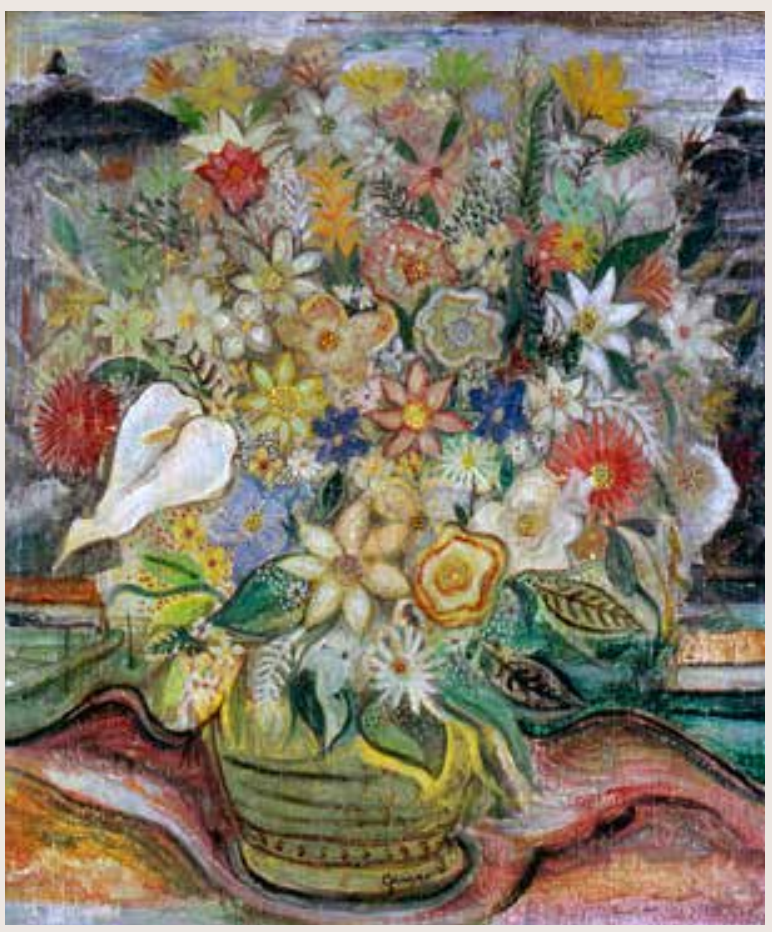

98 


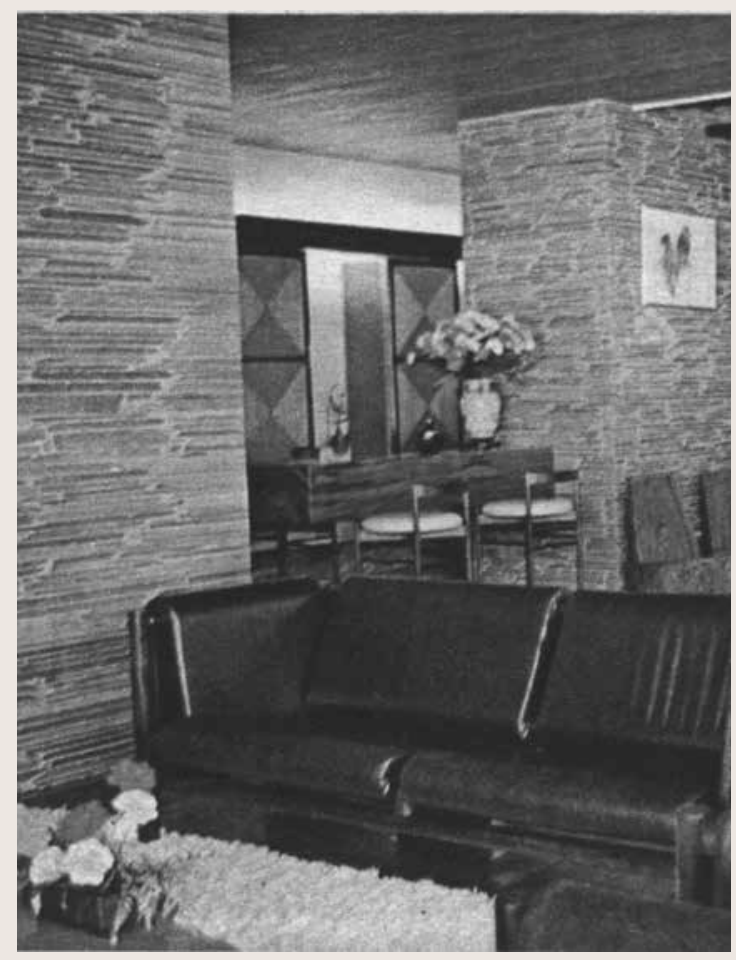


GUIGNARD E AS CIDADES QUE FLUTUAM EM NÉVOAS 
"Ora, a arte, e notadamente a pintura, nutrem-se nesse lençol de senti-

do bruto do qual o ativismo nada quer saber. Elas são mesmo as únicas a fazê-lo com toda inocência(...). O pintor é o único que tem direito de olhar para todas as coisas sem nenhum dever de apreciação. Dir-se-ia que, diante dele, as palavras de ordem do conhecimento e da ação perdem sua virtude...Como se houvesse na ocupação do pintor uma urgência que excede qualquer outra urgência. Ele aí está, forte ou fraco na vida, porém soberano incontestável nas suas mãos se dão, à força de ver, à força de pintar, obstinado em tirar, desse mundo onde soam os escândalos e as glórias da história, "telas" que quase nada acrescentarão às cóleras nem às esperanças dos homens, e ninguém murmura. Que ciência secreta é, pois, essa que ele tem ou procura? Nessa dimensão segundo a qual Van Gogh quer ir "mais longe"? Esse fundamental da pintura, e quiçá de toda a cultura?" Maurice Merleau-Ponty

O movimento moderno em Minas Gerais se deu a partir dos anos 1920 com repercussões no campo da cultura e uma série de inquietações em torno da renovação artística, com o surgimento de intelectuais que seriam os novos agentes da cultura. Segundo Klabin, ${ }^{1}$ Guignard ${ }^{2}$ tornou-se um ponto de referência 1982. p. 26

2 Alberto da Veiga Guignard (Nova Friburgo RJ 1896 - Belo Horizonte MG 1962). Pintor, professor, desenhista, ilustrador e gravador. Muda-se com a família para a Europa em 1907. Em dois períodos, entre 1917 e 1918 e entre 1921 e 1923, freqüenta a Königliche Akademie der Bildenden Künste [Real Academia de Belas Artes] de Munique, onde estuda com Hermann Groeber (1865 - 1935) e Adolf Hengeler (1863 - 1927). Aperfeiçoa-se em Florença e em Paris, onde participa do Salão de Outono. Retorna para o Rio de Janeiro em 1929 e integra-se ao cenário cultural por meio do contato com Ismael Nery (1900 - 1934). No ano seguinte, instala ateliê no Jardim Botânico, que retrata em várias obras. Participa do Salão Revolucionário de 1931, e é destacado por Mário de Andrade (1893 - 1945) como uma das revelações da mostra. De 1931 a 1943, dedica-se ao ensino de desenho e gravura na Fundação Osório, no Rio de Janeiro. Entre 1940 e 1942, vive num hotel em Itatiaia, pinta a paisagem local e decora peças e cômodos do hotel. Em 1941, integra a Comissão Organizadora da Divisão de Arte Moderna do Salão Nacional de Belas Artes, com Oscar Niemeyer (1907 - 2012) e Aníbal Machado (1894 - 1964). Em 1943, passa a orientar alunos em seu ateliê e cria o Grupo Guignard. A única exposição do grupo, realizada no Diretório Acadêmico da Escola Nacional de Belas Artes - Enba, é fechada por alunos conservadores e reinaugurada na Associação Brasileira de Imprensa (ABI). Em 1944, a convite do prefeito Juscelino Kubitschek (1902 - 1976), transfere-se para Belo Horizonte e começa a lecionar e dirigir o curso livre de desenho e pintura da Escola de Belas Artes, por onde passam Amilcar de Castro (1920 - 2002), Farnese de Andrade (1926 - 1996) e Lygia Clark (1920 - 1988), entre outros. Permanece à frente da escola até 1962, quando, em sua homenagem, esta passa a chamar-se Escola Guignard. Sua produção 
essencial, através da sua atuação como professor e artista plástico, estruturando pouco a pouco uma nova tendência estética, que modificaria sensivelmente as novas gerações de pintores que o sucederam.

O núcleo inicial do grupo modernista mineiro iria se congregar em torno de revistas e escolas literárias, apesar de se processarem divergências nas suas propostas estéticas, e tinham em comum uma atitude renovadora. Entre os componentes desta geração que tiveram participação ativa na vida intelectual mineira encontravam-se, entre outros: Carlos Drummond de Andrade, Emílio Moura, Pedro Nava, Martins de Almeida, João Alphonsus.

A academia Mineira de Letras, que havia sido fundada em 1909 em Juiz de Fora havia sido transferida dez anos depois para Belo Horizonte. Neste mesmo ano, Mário de Andrade realizara a sua famosa visita às cidades coloniais mineiras, percebendo a sua riqueza artística que era vista, ao longo do século XIX, como aberração ou excentricidade, em consequência da ânsia de europeização até então dominante e da obediência às normas neoclássicas. Mário de Andrade voltaria, em 1924, às cidades históricas mineiras com a caravana paulista modernista, viagem que seria um marco na redescoberta do

compreende paisagens, retratos, pinturas de gênero e de temática religiosa.

Por dedicar-se a praticamente todos os gêneros da pintura - retrato, auto-retrato, paisagem, natureza-morta, flor, pintura de gênero e pintura religiosa - costuma, em muitas obras, tratar de dois ou mais gêneros na mesma tela, como em suas naturezas-mortas, de número reduzido e quase sempre de caráter fantástico, que trazem uma paisagem ao fundo.

Os retratos, considerados por alguns críticos como a vertente mais fértil de sua obra, constituem a maior parte de sua produção e trazem pessoas de sua família, amigos ou filhos de amigos, intelectuais, artistas e auto-retratos. Nesses não deixa de fazer menção ao seu defeito congênito, o lábio leporino, também presente em representações de Cristo e outras figuras religiosas. Na produção de retratos destaca-se a obra As Gêmeas (1940), com a qual recebeu o prêmio de viagem ao país, na divisão moderna do Salão Nacional de Belas Artes. A tela retrata as irmãs Léa e Maura sentadas num sofá, tendo ao fundo a paisagem de Laranjeiras, bairro do Rio de Janeiro.

O crítico de arte Teixeira Leite vê na obra de Guignard traços da nova objetividade - movimento alemão que transpõe os limites do real, buscando impregná-lo de poesia -, aproximando-a, pelo tema tratado, à obra do pintor francês Henri Rousseau (1844 - 1910), especialmente na fase denominada lirismo nacionalista, representada por Casamento na Roça (1960), Família do Fuzileiro Naval (ca.1937) e Família na Praça.

Para o historiador da arte Rodrigo Naves, a pintura de Guignard tem um caráter decorativo acentuado, como a obra Os Noivos (1937), repleta de arabescos e outros motivos. Em sua pintura o decorativo está presente nos retratos, nos arranjos florais, nas estampas das roupas e em toda ornamentação em torno de seus modelos femininos, além de tetos, painéis, móveis e objetos que pintou. Guignard também inovou em sua atividade docente.

Na década de 1960, Guignard pinta as "paisagens imaginantes". Nelas, sua palheta volta-se para um cinza esbranquiçado e, como aponta Rodrigo Naves, tudo parece estar em suspensão, sem solo ou pontos de apoio firmes. Não há caminhos, acidentes geográficos nem distâncias. Há apenas um mundo nublado e tristonho.

Guignard, Alberto da Veiga. In: Enciclopédia Itaú Cultural de Arte e Cultura Brasileiras. São Paulo: Itaú Cultural. 
nosso material artístico.

Em 1925 surgiram diversas escolas superiores. Dois anos mais tarde foi criada oficialmente a Universidade de Minas Gerais, na qual Libeskind se formou arquiteto, na Escola de Arquitetura, em 1952.

O Movimento Moderno é lançado, então, em Minas em 1925, com a publicação de "A Revista" contendo artigos de Mário de Andrade, Emílio Moura, Carlos Drummond de Andrade, Pedro Nava, Manuel Bandeira, João Alphonsus, Abgar Renault, entre outros. Em seus editoriais divulgavam as suas propostas, revelando posições regionalistas dentro da ótica do nacionalismo, como se verifica nesta afirmação: "Procuraremos concentrar todos os esforços para construir o Brasil dentro do Brasil, ou, se possível, Minas dentro de Minas."

Se no âmbito da literatura o movimento modernista não encontrou serias resistências para penetrar no ambiente cultural mineiro, no terreno das artes plásticas o confronto com as estruturas acadêmicas se caracterizou, segundo Klabin, desde o seu início, "por um tom de acirrada polêmica, que levará à formação de duas facções, opostas que agruparam pró e contra as atividades do grupo Guignard."

Belo Horizonte, sob a administração do prefeito Juscelino Kubitschek, viveu três acontecimentos que provocariam uma enorme significação, sacudindo o morno ambiente cultural da capital mineira e gerando mudanças de rumo para as atividades artísticas.

A primeira iniciativa foi a abertura para a arquitetura moderna, alterando os padrões tradicionais e introduzindo novos conceitos na linguagem plástica. Isso se deu com o projeto de urbanização da área da Pampulha, para a qual são convidados artistas integrados ao espírito moderno.

Oscar Niemeyer, em 1942, desenvolveu um projeto para o conjunto da Pampulha, compreendendo várias edificações que seriam erguidas em torno da área do lago: o Cassino (atual Museu de Arte), o late Clube, a Casa de Baile e a Igreja de São Francisco de Assis. Dentro da ideia de integrar a arquitetura nas artes plásticas, Niemeyer teria colaboradores: Cândido Portinari, que realiza as pinturas de azulejos da Igreja; Athos Bulcão; Alfredo Ceschiatti, para a complementação escultórica, e Roberto Burle Marx, para a concepção paisagística. Com a construção do conjunto da Pampulha introduziu-se um novo repertório para a arquitetura moderna em Minas Gerais. A partir de então, várias obras dentro desta tendência seriam construídas na capital mineira, contribuindo para alterar a fisionomia da cidade.

No ano de 1944 a prefeitura de Belo horizonte patrocina a primeira 
grande mostra de arte moderna. Trata-se de uma exposição coletiva, que teve entre seus organizadores Oswald de Andrade, e que reunia os representantes mais significativos do movimento moderno: Tarsila, Di Cavalcanti, Segall, Portinari, Ismael Nery, Rebolo, Bonadei, Scliar, Clóvis Graciano, Heitor dos Prazeres, Djanira, entre outros. A participação de artistas não acadêmicos numa exposição de arte já era uma grande conquista para o acanhado ambiente cultural mineiro.

O catálogo da exposição (prefaciado por J. Guimarães Menegale) , procurou explicar: "Esta arte - a moderna - não é tão ilógica, tão enigmática, tão criptográfica, enfim, que o comum dos observadores, à força de vê-la, não acabe por compreende-la e, por consequência, estima-la... Minas tem, por excelência, a fonte de inspiração da arte moderna, pois oferece um ambiente, um clima, uma atmosfera específica no país, social e psicológica, que não se confunde com a do Rio e São Paulo e que poderá completar, com uma soma de fatores próprios, a originalidade da arte nacional".

O tema da Arte Nacional aparece como algo a ser perseguido dentro das expressões artísticas, sejam elas do campo da literatura ou das artes plásticas, e isso não seria diferente na arquitetura.

Ainda segundo Klabin, esta mostra de arte moderna teve as suas consequências não só com acentos agressivos, como a reação de uma visitante que rasgou com um canivete a tela do pernambucano Luís Soares, "A Nau Catarineta", como também foi a causadora de múltiplas controvérsias e incompreensões, gerando uma série de debates e conferências. Era o início de um período de agitação em torno de novas ideias, iniciando-se uma tímida reação ao espírito acadêmico.

No âmbito de tais acontecimentos, é criada a Escola de Belas-Artes, em 1943, para a qual Guignard é convidado por Juscelino, com o objetivo de dirigir um curso livre de desenho e pintura, e a ideia era justamente contratar um pintor moderno que viabilizasse a implantação de novas normas estéticas capazes de implantar o espírito vanguardista em Belo Horizonte.

Guignard já havia trabalhado como professor de desenho e pintura na Fundação Osório, no Rio Comprido (1934/43); num curso de desenho livre na antiga Universidade do Distrito Federal (1935), por um período de seis meses e num curso gratuito de desenho e pintura na sede da União Nacional dos Estudantes, na Praia do Flamengo. Nesta época ele estava instalado num atelier coletivo, do qual faziam parte, entre outros, Alcides da Rocha Miranda, Iberê Camargo, Geza Heller, Milton Ribeiro, Elisa Byington, Werner Amacher.

O convite feito por Juscelino é imediatamente aceito e Guignard trans- 
fere-se para a capital mineira, da qual nunca mais se afastou, a não ser provi-

soriamente, desenvolvendo as suas atividades entre Belo Horizonte, São João del Rei, Sabará e Ouro Preto. O seu afastamento do Rio de Janeiro, então palco das discussões travadas entre os acadêmicos e modernistas, teve algumas repercussões. A este respeito, acrescenta Quirino Campofiorito:

"Houve um pouco de polêmica no ambiente artístico sobre se Guignard deveria ou não ir para Belo Horizonte; se isto correspondia a um benefício para Guignard ou para Belo Horizonte. Eu fui um dos que foram contra, porque se Guignard naquele tempo não podia se expandir no Rio de Janeiro, imagine então em Belo Horizonte. Nós não estávamos pensando no futuro de Belo Horizonte, mas no futuro da arte. Belo Horizonte era uma grande-aldeia. Seria benéfico para os alunos, mas não para Guignard. Manifestei-me contra isto, mas Guignard foi para lá e foi muito bom; os alunos lucraram muito. Aqui perdeu-se um pouco de Guignard."3

A presença de Guignard em Minas e sua atuação frente à Escola do Parque, como era chamada, iria gerar uma série de conflitos frente a estrutura acadêmica. A implantação e a consolidação da pintura moderna foram realizadas com muitas dificuldades, como registra o seu aluno Mario Silésio:

"Guignard foi quem trouxe realmente para Belo Horizonte a maneira de enxergar a pintura moderna. Nós tivemos uma exposição de pintura moderna brasileira com Portinari, o próprio Guignard, Anita Malfatti, etc. Já havia um início, mas o povo não se sentia bem em relação à modernidade. Com a vinda de Guignard é que começamos a fazer exposições, conferências e aqui se criou um certo movimento que dura até hoje. Quase todo dia a imprensa apoiava com artigos, entrevistas com alunos, tudo para movimentar. Foi com ele que realmente surgiu o movimento modernista. Ele encontrou um campo fértil, com todos os alunos dedicados a ele, sem nenhum conhecimento anterior".

Pode-se afirmar que a Escola instalada no Parque Municipal seria o marco inicial do movimento modernista em Minas Gerias e Guignard participou efetivamente da luta entre modernistas e acadêmicos.

3 ZILIO, Carlos (coord). A Modernidade em Guignard. Pontifícia Universidade Católica. Centro de Ciências Sociais. Departamento de História e Coordenação de Cursos de Extensão. Rio de Janeiro: Lis Gráfica e Editora Ltda., 1983. p. 18

4 KLABIN, 1982. p.46 
Segundo Klabin instalou-se um período de inimizades, indisposições, incompatibilidades e agressões que envolveram as duas facções - acadêmicos e modernistas - e Guignard foi um destes protagonistas, que entrou na luta depois de ser empurrado para ela, porque não era exatamente este o perfil da personalidade de Guignard - estar à frente de um embate.

A Escola de Belas-Artes criada em 1943 por Juscelino Kubitschek, vai sofrer uma modificação através do decreto municipal no. 151, datado de 28 de fevereiro de 1944. Por este decreto fundou-se o Instituto de Belas Artes, que funcionava como um curso livre, mas com conteúdo superior. O objetivo era enquadrar os cursos ministrados na Escola de Arquitetura em correspondência aos da Escola de Belas-Artes do Rio de Janeiro, visando garantir o reconhecimento federal e, portanto, a sua inserção no sistema oficial de ensino da arquitetura que havia se iniciado com a Missão Artística Francesa.

Esta linha de ensino não é, entretanto, aceita por Guignard, que vai ter uma atuação importante no sentido de preservar a autonomia didática para a Escola de Belas-Artes, não se sujeitando a nenhum tipo de regulamento que pudesse enquadrar o seu curso dentro de um sistema acadêmico de ensino equivalente ao da escola Nacional de Belas-Artes. A união destas escolas acaba fracassando, sendo que em 1946 a Escola de Arquitetura é incorporada à Universidade de Minas Gerais e o Instituto de Belas-Artes sofre uma reforma administrativa em 1947, adotando o nome Curso de Belas-Artes.

Em 1948 o prefeito Otacílio Negrão de Lima decide fechar a Escola, sob a alegação de que "favorecia sensivelmente as tendências artísticas modernas", indo justamente contra o princípio colocado por Juscelino ao trazer Guignard para Belo Horizonte. Apesar do esvaziamento institucional em que a Escola se viu mergulhada e da ausência completa de assistência material à Escola, Guignard continuou lecionando para uma turma composta de sessenta alunos. É instituída uma comissão diretora composta por Guignard, Amílcar de Castro e Mário Silésio, com o objetivo de obter uma subvenção através do governo do Estado e de se registar a escola como uma sociedade civil.

Apesar das dificuldades, a atuação autônoma de Guignard frente à sua Escola abriu novos caminhos trazendo uma enorme contribuição não só para a formação dos primeiros artistas modernos como também para a implantação e o desenvolvimento da arte moderna em Minas. Nas palavras de Otto Lara Rezende:

"A verdade é que a Escola de Belas-Artes de Belo Horizonte se confunde com Alberto Guignard. Talvez aí esteja a sua grande vantagem: a Es- 
cola é o pintor Guignard, auxiliado por uma assistente, Edith Behring,

ex-aluna de Portinari. Guignard ensina atualmente a 60 alunos. $\bigcirc$ método de ensino é o mais antiburocrático possível. Não há atribuição de notas, nem livro de presença, nem divisão do curso em anos... $\bigcirc$ que sabe - e todos eles sabem - é que estudam com Guignard, que assiste a cada um individualmente, segundo o desenvolvimento e as tendências de cada discípulo particularmente. Trata-se de uma escola como já não se vê hoje em dia, qualquer coisa que sugere a atmosfera medieval com os aprendizes em torno do mestre."

Corpo e alma da Escola, Guignard a ela se dedica intensamente. Até o início de 1949 teve Edith Bhering como assistente. Franz Weissmann ensinou escultura até 1954, quando as aulas são suspensas por falta de verba.

Em 1954, Guignard vai para Ouro Preto, onde passa a maior parte do tempo e morre em 1962.

Mario de Andrade irá destacar, em 1944, a importância do trabalho de Guignard na "Escola do Parque" ou "Escolinha do Parque" como era costumeiramente chamada: "entre os milagres do Brasil, havemos de colocar Belo Horizonte, e entre os bons milagres, ela mantem agora uma escola Municipal de Pintura, dirigida por Veiga Guignard."

A partir de 1946, Libeskind então com 18 anos, passou a frequentar as aulas de pintura de Guignard e em pouco tempo se transformou em um de seus destacados alunos. Durante os primeiros anos, sob a orientação do mestre, realizava pintura figurativa, pintando paisagens das cidades históricas mineiras, tendo sido publicado em diversas oportunidades nos jornais da época.

Enquanto professor, Guignard dará inteira liberdade de expressão aos seus alunos, não havendo uma imposição para uma determinada conduta estética. Analisando o seu método antiacadêmico de ensino, Mário Silésio afirmou: "Ao contrário dos outros mestres acadêmicos que ensinaram dentro das salas, servindo-se da memória ou de elementos subsidiários, Guignard foi ao encontro da natureza, aconselhando aos seus alunos que tomassem o assunto que mais Ihes interessasse. Cada qual dispõe o cavalete onde quer, ajustando-se ao motivo e de todos os recantos do Parque começavam a surgir estudos e telas, algumas muito curiosas. Se Guignard Ihes deu a liberdade de escolha, deu-Ihes igualmente a liberdade de inspiração pictórica".

Cabe destacar o método de ensino de Guignard, que iniciava o processo com desenho de observação a lápis de grafite dura $(2 \mathrm{H}, 4 \mathrm{H}, 5 \mathrm{H}$ ou até $9 \mathrm{H})$.

5 REZENDE, Otto Lara. "Guignard e 60 Aprendizes". Rio de Janeiro: O Jornal, 1/01/1949. 
"Havia uma liberdade absoluta. Podia tudo. Mas tinha certas coisas importantes.

Essas coisas marcavam muito os alunos, a necessidade de precisão, de ordem, de organização, de estrutura. Isso é Guignard. (...) O desenho dele é limpo, simples, direto, sem sombra nenhuma. Quase como uma gravura no papel. Esse é o sentido que ele trouxe para aqui. Quando entrávamos na escola a única coisa que ele queria era que desenhássemos. Se não tivesse qualidade, qualidade de arte, ele ia batalhando com o aluno até sair qualquer coisa. Ele ensinava preparação de tela, de tinta, mas não era isso o importante. O principal era a forma, a linha, a feitura da linha. (...) Não era um sujeito de organizar coisas, mas sabia que aquele era o caminho".6

Em depoimento, a artista Yara Tupinambá, aluna de Guignard, se lembra: "Não interessava a cópia da natureza, mas uma interpretação do que víamos e do que era melhor. Era uma filtragem em vez de ser uma cópia."

Jefferson Lodi, também seu aluno, complementa: "O modo dele corrigir um desenho era muito interessante: recortava uma "janelinha" num cartão, ia passando pelo desenho e comentando à medida que encontrava um trecho que achava bom ou ruim. Os comentários eram muito interessantes e nos faziam voltar ao original e observar de novo. Era uma fragmentação do trabalho, onde ele salientava as linhas e a composição."

Ou ainda Sara Ávila também recorda: "Aprendemos com ele o que depois ficou na moda - a capacidade de concentração, a observação. Íamos todo dia para o parque e lá ficávamos, observando a ordem da natureza, a formação das plantas. Ele não ensinava, a gente descobria sozinho. $\bigcirc$ entendimento com ele era feito através da sensibilidade, como se fosse pela pele. Por mais que se descreva, não dá para conhecer como ele era realmente. Querer julgar Guignard como nossos padrões não dá. Ele era diferente da gente."

Guignard, na medida em que não elaborou teoricamente seus conceitos e nem estabeleceu bases para um método de trabalho definido e sistemático, foi um ato que começou e terminou em si mesmo. Único e irreproduzível, já que totalmente dependente da força de uma personalidade e só possível em dado momento histórico graças à conjunção de fatores propícios diversos tais como localização, contexto político e social, indivíduos específicos e especiais.

Era uma fusão de disciplina e liberdade, pois, segundo relato de Li- 
beskind, "em um dia ela dava lápis duro, no outro alguma coisa para soltar a

imaginação, um trabalho mais solto de manchas, e isso era uma maravilha - me marcou muito, sabe?"

Esmiuçando a importância do método para os alunos, Amilcar de Castro - citado em artigo de Susane Worcman - faz sua descrição daquela época: "essas coisas marcavam muito os alunos, a necessidade de precisão, de ordem, de organização, de estrutura. Ele ensinava preparação de tela, de tinta, mas não era isso o importante. O principal era a forma, a linha, a feitura da linha."

E no exercício com este lápis duro o futuro arquiteto Libeskind revelaria seu talento artístico. As lições de Guignard se revelariam presentes nas várias camadas de expressão experimentadas por Libeskind durante toda sua vida, sobretudo onde o desenho e a pintura se encontravam - pistas para compreender os seus projetos de arquitetura, através das suas experiências gráficas com a cor e com os materiais. Isso é revelado em toda a sorte de revestimentos por ele empregados, superfícies opacas e brilhante, transparentes e turvas. Natureza imagética e pele da matéria.

"O caminho pelo qual se chega a determinado resultado, ainda que esse caminho não tenha sido fixado de antemão de modo deliberado e refletido", era, segundo Silésio, o resultado que Guignard buscava para a formação de artistas e não de discípulos.

E Guignard dizia: "São três as minhas exigências, mas muito importantes: faço questão que meus discípulos tenham estes atributos: disciplina, tenacidade e amor à sua arte. $\bigcirc$ resto vai bem, pois o meu ensino consiste em demonstrações práticas tanto no desenho como na pintura. Porque - digamos a verdade - desenhar não é brincadeira. É uma arte muito séria e nela só chegamos a resultados que podem ser ótimos com uma grande força - na observação e na perseverança."

E o artista permaneceu à frente da Escola do Parque, em Belo Horizonte, até sua morte.

Alguns fatos expressivos sobre a sua produção: em 1927 expõe no Salão do Outono, em Paris, em 1928 conhece Picasso, reside em Paris e participa de Bienal de Veneza.

Em 1929, expõe no Salão dos Independentes, no Grand Palais, em Paris, e retorna definitivamente para o Brasil e reside no Rio de Janeiro, onde torna-se amigos dos pintores Pedro Correia de Araújo, Ismael Nery, Cândido Portinari, Di Cavalcanti, e dos escritores Murilo Mendes, Jorge de Lima e Aníbal Machado e do gravador Goeldi.

Em 1942 o Museu de Arte Moderna de Nova York adquire o quadro 
“Noite de São João", e, em 1944, participa da Exhibition of Modern Brazilian Painting na Royal Academy de Londres, e neste mesmo ano o arquiteto Sylvio de Vasconcellos (professor de Libeskind na Escola de Arquitetura) leva Guignard nas pequenas viagens que realiza a serviço do SPHAN às cidades históricas do ciclo do ouro.

Em 1953 envia oito desenhos para a II Bienal de São Paulo, retirando-se da mostra em seguida, em um gesto de apoio aos protestos de artistas paulistas contra a arbitrariedade dos organizadores e, neste mesmo ano, ganha uma retrospectiva de sua obra no Museu de Arte Moderna do Rio de Janeiro.

Apenas em 1956 é realizada a retrospectiva de sua obra em São Paulo, no IAB, organizada por David Libeskind. Parece que São Paulo demorou um pouco para reconhecer o talento de Guignard e isto ficou a cargo de Libeskind. Esta exposição, apesar de não se configurar como uma retrospectiva, contou ao todo com trinta e quatro trabalhos do artista, entre eles, "Autorretrato" e "A Família do Fuzileiro" (pertencente ao espólio de Mário de Andrade), com obras das coleções de Lúcia Machado de Almeida, de Sylvio de Vasconcellos e de Mário Silésio.

Libeskind iniciou seus estudos de pintura aos seis anos de idade e destacou-se de imediato. Por sua sensibilidade artística, era frequentemente estimulado por professores e incentivado já desde muito cedo a divulgar sua produção. Em suas reminiscências há lugar para Dona Olímpia, professora e artista amadora, sua primeira incentivadora; para Dona Julieta, professora do Grupo Escolar, que enviava seus desenhos e pintura para o Jornal O Estado de Minas para serem publicados no caderno infantil; para Dona Conceição Lobato Felisberto, que ministrava aulas extras de figuras no Ginásio, as quais resultavam em paisagens e relevos de gesso que eram vendidos sob encomenda e rendiam algum dinheiro para o jovem artista.

Mas se deve ao estudo da pintura sob orientação do mestre Alberto da Veiga Guignard - artista brasileiro com formação na Alemanha e Itália, e conhecido por suas telas com paisagens de Minas Gerais - a fase mais significativa da sua formação artística. Foi aluno do pintor modernista durante os anos de 1946 e 1947, mas durante todo o período universitário continuou frequentando periodicamente seus cursos, quando possível.

O rápido sucesso profissional de Libeskind como arquiteto após sua chegada em São Paulo afastou-o, temporariamente, da prática artística, mas não do contato intenso com a arte e com o meio cultural efervescente da metrópole.

Ainda na década de 1950, Libeskind volta a exercer, paralelamente à 
sua atividade principal de arquiteto, uma prática já iniciada em Belo Horizonte,

em 1951, quando ilustrou a capa da revista mineira Arquitetura e Engenharia. Apesar de não se tratar do seu ofício principal, manteve uma regularidade bastante significativa, trabalhando como ilustrador gráfico entre os anos de 1954 e 1960, quando conseguiu manter uma média de produção de 5 a 6 capas de revistas por ano.

No final da década de 1950, Libeskind foi convidado pelo arquiteto Fabio Penteado para realizar as ilustrações das capas da revista Visão (edição de 29 de março de 1957), uma das mais expressivas revistas brasileiras da época. Dedicou-se nos três anos seguintes (até a edição de 24 de junho de 1960) à produção de várias capas desta revista que, em termos de projeção, transcendia o limitado campo das revistas especializadas para atingir o patamar da tiragem em grande escala com distribuição nacional.

Também se dedicou à ilustração de revistas especializadas, como por exemplo, a AD - Arquitetura e Decoração e a Revista de Engenharia Mackenzie, à ilustração de capas de livros e de catálogos para empresas especializadas em produtos para o ramo da construção civil. Ainda em 1957, o arquiteto dirigiu a revista Brasil Arquitetura Contemporânea.

Pode-se notar que Libeskind utilizou de forma recorrente nos seus trabalhos de ilustração gráfica o desenho livre, à mão, despojado, seja de forma figurativa, seja no tratamento gráfico de composições abstrato-geométricas, chegando, às vezes, na própria tipografia.

No campo da ilustração ${ }^{7}$ Guignard também atuou com tamanha desenvoltura e ao modelo do mestre, Libeskind seguiu o seu caminho. À semelhança de Guignard, é notória a convergência da técnica empregada, no que diz respeito ao grafismo, no apuro da linha, no traço que marca o contorno, quase

7 A sólida formação técnica adquirida por Guignard entre 1917 e 1922 na Real Academia de Belas Artes de Munique possibilitou que ele transitasse com desenvoltura pelos mais variados campos do fazer artístico. Assim, não se limitando apenas à pintura, seu legado também nos traz importantíssimas contribuições como desenhista e ilustrador gráfico, o que por si só bastaria para garantir sua imortalidade artística.

Ao longo de sua carreira, Guignard colaborou com vários jornais, na qualidade de ilustrador, principalmente dos suplementos literários, tão importantes na primeira metade do século XX. A mais conhecida dessas colaborações é o chamado Álbum Guignard, composto por desenhos feitos pelo artista em suas viagens pelo Brasil, de ilustrações de poemas e textos literários, que o suplemento literário do jornal A Manhã publicou esparsamente entre os anos 1942 e 1949. Existe também uma série de livros que foram ilustrados por Guignard: Manuel Bandeira - Poemas Traduzidos (1945); Alexandre Konder - Os Halifax (1952); Tomás Gonzaga - Marília de Dirceu (1944); Lúcia Machado de Almeida - Passeio a Sabará (1952); Lúcia Machado de Almeida - Passeio a Diamantina (1960) e Celina Ferreira - Hoje Poemas (1966). Informações coletadas no catálogo da exposição do Museu Casa Guignard, Ouro Preto, MG, 2017. 
ferindo a superfície do papel. Dessa forma, Libeskind também irá flutuar entre o desenho "arquitetônico" (percebido inclusive nas suas últimas ilustrações, datadas de 2012, com um grafismo rítmico, muito construído, ainda que seja para tratar de temas naturais) e um desenho de outra natureza, que servirá como esboço inicial para as suas telas, onde a cor (assim como em Guignard) assume o controle.

Ele volta a dedicar-se à pintura somente no final da década de 1950 e logo depois, em 1961, recebeu o I Prêmio no Salão Paulista de Arte Moderna, em São Paulo.

Seguem a partir deste momento algumas participações em eventos ligados às Artes Plásticas, com destaque para o 12. Salão Nacional de Arte Moderna, no Rio de Janeiro, em 1963; a VII Bienal de São Paulo, em 1963; o $13^{\circ}$. Salão Nacional de Arte Moderna, no Rio de Janeiro, em 1964; o 1. e o 2. Salão de Arte Moderna do Distrito Federal, em Brasília, em 1964 e 1965, respectivamente; a VIII Bienal de São Paulo, em 1965; o 15․ Salão Paulista de Arte Moderna de São Paulo, em 1966, onde obteve medalha de prata; a Mostra Individual na Galeria Documenta, em São Paulo, em 1971 e ainda, em 1984 na mostra Tradição e Ruptura da Bienal de São Paulo.

Ganhador do concurso para o cartaz e catálogo da VII Bienal de São Paulo de 1963, Danilo Di Prete é o grande incentivador para Libeskind enviar uma obra para a seleção dessa edição da Bienal. A seleção do quadro representou para Libeskind um marco para a retomada da sua carreira nas artes plásticas, tendo participado a seguir da VIII Bienal de São Paulo, em 1965, e da IX Bienal de São Paulo, de 1967.

Di Prete, que supervisionava nesse período as montagens das Bienais, convida o amigo Libeskind para acompanhá-las, o que Ihe vale a oportunidade de travar contato com a produção de inúmeros artistas de várias partes do mundo, que participavam das Bienais de São Paulo. Dentre eles, Libeskind destaca a obra do italiano Alberto Burri, apresentada por Di Prete na III Bienal de 1955 e que imediatamente o fascinou.

As associações com o artista e seu papel no imaginário e na formação do jovem Libeskind assim como a presença metafórica de Guignard na sua casa está representada, entre outros elementos, pela coleção de obras de Arte que Libeskind reuniu durante toda a sua vida.

São peças que reafirmam o caráter dessa arquitetura na busca da construção de uma ambiência total que se integra com a Arte, e do reconhecimento da produção cultural de um período. Sua pinacoteca particular era composta por esculturas de Francisco Stockinger, Bruno Giorgi, Ernesto de Fiori, Alfredo 
Ceschiatti, Vitor Brecheret e telas de Danilo Di Prete, Oswaldo Goeldi, Emilia-

no Di Cavalcanti, Alberto da Veiga Guignard, Antônio Bandeira, José Pancetti, Anita Malfatti, George Mathieu, Manabu Mabe, Alberto Burri e de sua própria autoria.

Seu entusiasmo no convívio com os artistas foi uma das lições que Guignard deixou para Libeskind. A Arte jamais deixaria de existir na sua vida e na sua casa e sobre a fusão entre Arte e Arquitetura, Libeskind revelou certa vez: "Não faço arquitetura se não estiver pintando, não pinto nada se não estiver projetando".8

A existência de Guignard na formação de Libeskind nos anos 1940, em Minas Gerais, marca um lugar de importância vital para a compreensão da linguagem em formação do jovem arquiteto. Sua ação em construir uma Arquitetura - que embora fortemente vinculada às lições e códigos modernos internacionais, que não passaria incólume aos direcionamentos e ensinamentos recebidos na Escola de Arquitetura, sobretudo pontuada pela presença de Sylvio de Vasconcellos, - buscou nas referências nacionais - Oscar Niemeyer (em um primeiro momento), Oswaldo Bratke e Rino Levi - e no reconhecimento de uma cultura própria em construção a consistência que amparou a possibilidade de reunir universos centrais e periféricos, entre o colonizador e o colonizado, que de certa forma estava vinculada a uma "modernização que trouxe um grau de ruptura e de desarraigamento, mas que também permitiu que a ideia de uma cultura nacional fosse moldada e formulada de novas maneiras. A própria abstração da arquitetura moderna ofereceu ao arquiteto perspicaz os meios para transcender o provincianismo e o paroquialismo enquanto evocava ecos das formas básicas e mitos antigos de tradições locais em um nível generalizado." ${ }^{\prime}$

Essa raiz nacional forjada na pesquisa material, na natureza expressa nos ensinamentos de pintura da Escolinha do Parque de Guignard, no levantamento da arquitetura barroca em Ouro Preto junto ao Iphan, na observação das primeiras obras de Niemeyer (sobretudo em Pampulha), resultaram em reverberações futuras na obra madura de Libeskind, quando desenho, pintura, ilustração, arquitetura, figuração e abstração já haviam encontrado o espaço do equilíbrio que marcou predominantemente a sua produção reconhecida pela excelência das décadas de 1950 e 1960 em São Paulo.

No processo investigativo a respeito das influências de Guignard im-

Depoimento de Libeskind à autora, em 2002.

9 CURTIS, William J. R. (1982) Arquitetura Moderna desde 1900. 3. Ed. Porto Alegre: Bookman, 2008. p. 493 
pressas em Libeskind, há de se contextualizar o momento histórico em que isso ocorreu, ou que Belo Horizonte era essa em que Libeskind iniciava a sua formação artística e sua aproximação com o universo da Arquitetura. Mas não menos importante, e talvez de fundamental relevância para a construção deste trabalho, é compreender o fazer Guignard na pintura, o seu modo de ler e resgatar nas telas a natureza brasileira e a cidade mineira, o seu processo de ensinar a pintar a partir do desenho, que imprimia nos alunos um pêndulo entre o rigor da linha e a soltura da cor.

Ademais, o convívio com o mestre Guignard marcaria uma geração de artistas que com ele conviveu e que registrou em Libeskind o gosto pela ilustração, pelo rigor da feitura do traço, pela investigação cromática e material que apareceria depois na sua obra arquitetônica e nas suas incursões pelas artes plásticas, quando das investigações abstratas das décadas de 1960 e 1970.

Mas uma outra referência, essa inicial, decisiva, ainda nos anos 1940, em Belo Horizonte, fez com que Libeskind decidisse, ainda muito jovem e frequentando as aulas de Guignard na Escolinha do Parque, pela carreira de arquiteto. Foi uma época agitada em Belo Horizonte, segundo ele, com a presença de Juscelino e Niemeyer por ali. Momento esse coroado pelo episódio da tela cortada a canivete na Exposição de Arte Moderna de 1944.

Libeskind visitou as obras de Pampulha, por volta de 1942 e tal episódio foi de imenso impacto para ele. Havia uma dúvida sobre qual carreira seguir, uma vez que a família manifestava preferência pela Engenharia e Guignard guardava grandes expectativas sobre o pupilo seguir com a carreira das Artes Plásticas. Libeskind decepcionou a ambos, pois depois de Pampulha, decidiu estudar Arquitetura e é incontestável a presença dessa influência nos seus primeiros estudos e projetos, sobretudo em sua primeira casa construída, ainda em Belo Horizonte, a residência Ângelo Aurélio Rezende Lobo, de 1942. Há nessa obra o espelho presente da plasticidade e das lições de arquitetura do mestre Niemeyer. "Guignard queria me matar", Libeskind recorda do seu ato heroico e decisivo pela profissão.

"Há uma sensibilidade Guignard. Em nosso imaginário artístico tem um peso de fato - a imagem do Brasil moderno passa pelo seu colorido, a paisagem se confunde um pouco com a estrutura formal de seus quadros. Através de seus signos plásticos reconhecemos uma certa definição do nosso ser - o lirismo nacional. A expressão de nossa alma, esta parece ser a ideia vigente Guignard. Aí estaria, portanto, um dos marcos do modernismo: assim como Portinari representa a identidade histórica 
Segundo Carlos Zílio, existe um elemento pictural capaz de nos fornecer acesso à compreensão da obra de Guignard. Esse elemento, presente em todos os temas que abordou e em todas as suas fases, é a nuvem:

"Operando como uma espécie de motivo-síntese das transformações havidas no procedimento pictórico de Guignard, podemos observar no tratamento das nuvens as tensões que percorreram a obra do artista, no seu processo de captação da modernidade. Esta luta de Guignard com a tradição se reveste de um significado maior, uma vez que se situa dentro de uma questão mais ampla da História da Arte, em que a nuvem, aí também, como elemento pictural, terá um significado particular. Na pintura ocidental, da Grécia aos iluministas, é atribuído ao desenho o fundamento da pintura, uma vez que aquele seria a estrutura básica desta, restando à cor um papel meramente complementar. A nuvem, por contradizer a ordem delineatória, contraria esta concepção, situando-se consequentemente como o elemento fora da norma."

Ainda sobre a nuvem, "É sabida a forte repercussão que teve o impacto da luz sobre Guignard no seu retorno ao Brasil. O desafio de novas possibilidades cromáticas tornou-se um problema para sua formação europeia. Pacientemente, Guignard foi elaborando soluções capazes de apreender as cores tropicais. (...). Em linhas gerais, pode-se afirmar que seu trabalho tendeu de uma pintura realizada por cores rebaixadas e matéria densa, onde as formas são delineadas por um traço preto, para uma pintura de cores intensas, com a tinta bastante liquefeita, sendo que os contornos, quando assinalados, o são ligeiramente e por meio da cor. Esta crescente liberação cromática, que coincide com uma pincelada cada vez mais solta, altera também a importância da nuvem na sua pintura. De componente de fundo, torna-se cada vez mais um elemento presente, chegando a dominar em alguns trabalhos, através de uma fusão com as montanhas, toda a superfície da tela. Neste percurso sua pintura tenderá cada vez mais a uma abertura para a subjetividade."

Zílio denota a nítida influência de Cézanne na pintura de Guignard, sobretudo na divisão do espaço, o que pode ser constatado nas naturezas mortas pintadas por Guignard e nas gradações cromáticas na relação entre volumes. Brasil da PUC/RJ. In: ZILIO, 1983. p. 18-21 
Para Argan, a produção de Cézanne conclui a parábola do Impressionismo e forma o tronco do qual nascem as grandes correntes da primeira metade do século XX. Fez da obra a sua vida, renunciou a ter uma vida para realizar sua obra.

A sua pintura, segundo o autor não era literatura figurada, tampouco uma técnica capaz de transmitir a sensação visual ao vivo: era um modo insubstituível de investigação das estruturas profundas do ser, uma pesquisa ontológica, uma espécie de filosofia. Nesse sentido, a operação pictórica não reproduz, e sim produz a sensação: não como dado para uma reflexão posterior, mas como pensamento, consciência em ação.

Seria aí onde o céu não se destaca, mas une-se à crista das colinas o lugar indefinido onde é possível também reconhecer o Guignard que fez da sua pintura a sua própria vida, de tal modo embriagado onde a luz se tornou matéria, na espessura das cores "e não tem transparência e nem brilho, apenas uma vibração pesada, como um zumbir nos ouvidos."

Como em Cézanne, Guignard vai afinar o empaste, e utilizará a aquarela, um meio mais diáfano. Posto que da mesma forma parece que tudo é atmosfera, tudo é céu e montanha, nuvem e paisagem, igrejas e nuvens, balões e árvores.

Não são elementos conhecidos representados na tela. São a imaginação de Guignard reverberando na tela, e tudo em fusão, se mistura e se desmancha imersos numa outra lógica da perspectiva ou da ordem. De componente de fundo, o céu e a nuvem tornam-se cada vez mais elementos presentes, chegando a dominar em alguns trabalhos, através de uma fusão com as montanhas, toda a superfície da tela. Neste percurso sua pintura tenderá cada vez mais a uma abertura para a subjetividade, e a nuvem admitirá todas as formas e todas as cores.

Talvez para Guignard o limite entre o real e o poético não fosse muito preciso.

No processo de superação do conflito entre o desenho e a cor, as nuvens vão tomando e determinando a tela através de pequenas pinceladas, vai surgindo pelo acúmulo de sucessivas camadas, tal como a formação das nuvens em seu processo de condensação.

Seria esse "mundo que se dissolve na lógica das aparências, onde o real se resume ao fluxo volátil de relações sem uma ordem arquitetônica que o sustente"11, o mundo de Guignard? 
Ele mesmo, o homem e o pintor não poderiam ser uma coisa ou outra e aquela paisagem de Ouro Preto passou a habitar em Guignard. $\bigcirc$ artista que fez do desenho, a base, servindo à vertigem da cor, que passou a ser o sujeito da pintura, passou a ser a sua própria estrutura.

Se em Guignard a cor aquarelada define a forma difusa e ela é o próprio gesto na indefinição da paisagem que se mescla e que mistura as partes da paisagem (montanha, céu, nuvem, árvore) nas experiências em pintura que Alberto Burri - principal referência da arte informal para Libeskind - realiza com os materiais há o resíduo; há também uma manipulação deste material original até que não se reconheça a sua proveniência, há transformação através da ação, da sobreposição e da mescla. A cor, aí, é resultante de fusão e da energia, mas não menos importante, ela surge intensa e vigorosa.

Em ambos os casos - com resultados e origens absolutamente distintos - a cor é elemento investigativo. Não a cor, em si, mas a forma como ela é tratada para que se chegue no resultado esperado.

E em ambos os casos o limite do desenho não é claro, perde-se a linha de contorno porque a intenção é homogeneizar o campo pictórico ainda que aquilo que se pretende mostrar pertença ao campo figurativo ou abstrato.

Assim a cor é um elemento definitivo para Libeskind também. Um canal utilizado pelo arquiteto para garantir a ambiência perseguida nos seus projetos. Os materiais por ele empregados para além do discurso da matéria, tem neles implícito o código da cor e tudo o que nela está implicado - brilho, opacidade, transparência e turbidez.

O fundamento da chamada "brasilidade" da obra de Guignard, provavelmente nada tenha de conexão com o nacionalismo instituído predominantemente nos anos 1930 e 1940 já apontados pelas iniciativas de abertura à arte moderna em Minas Gerais, mais precisamente em Belo Horizonte, regida pelo entusiasmo de Juscelino Kubitschek ou de uma arte engajada e política.

Talvez Guignard só estivesse em busca de adequar sua paleta europeia à luz dos trópicos, procurando encontrar no Brasil uma ambiência afetiva, e isso tenha resultado em uma linguagem muito pessoal, coincidente com o início do Modernismo. Seu modo de fazer estava apoiado num mundo com substância, real e sua missão era reconfigurá-lo através da pintura.

É uma expressão que pressupõe o mundo dado, mas que através da imaginação artística o altera, o reagencia, e há, segundo Zílio, "uma grande disponibilidade "moderna" em tudo isso, cores e formas obedecem "livremente" à imaginação do artista. É uma poética da transfiguração. (...) Guignard chegou "moderno" da Europa e nesse nível preliminar de modernidade permaneceu. 
O Brasil, vasto, vago e ignaro Ihe impôs de saída uma enorme tarefa: a de conquistá-lo e interpretá-lo com os meios de que dispunha. Guignard tentou dominá-lo pelo excesso de luz e espaço, através de um singelo sentimento pictórico, única manobra capaz de abarcá-lo sem contradição."

Ainda segundo o autor, "ao contrário de Tarsila, que foi procurar o Brasil no futuro, na metrópole de São Paulo, Guignard quis apreendê-lo a partir de seu passado mítico, Ouro Preto e Diamantina. Em Tarsila os planos visuais se superpõem como esforço de racionalização, vontade de saber, obediência às novas determinações da realidade industrial. Nas Noites de São João de Guignard os vários planos se confundem e distinguem como passe de mágica e sonho - é uma percepção atual querendo resgatar o mito de um mundo organizado por sensações solidárias. Nessas telas, no tempo histórico especifico delas, no tênue real de sua linguagem, o Brasil conseguiu se realizar assim. Por alguns momentos fugazes, o Brasil existiu, plenamente, como um conjunto de sensações solidárias."

O tempo em Guignard parece ser outro, entre aquilo que existe e o que está se desmanchando, o que está evaporando para retornar à terra. O tempo em Guignard é água, ilusão óptica que imprime na paisagem dos seus quadros o seu lirismo - sua condição interna e drama pessoal.

Guignard é o começo, a nuvem, presença expressa na relação com a vida e com a casa de Libeskind. A imaginação e a criação de um mundo novo, de uma vida a se construir, aquilo que está em formação. Este elemento simboliza o devir de metamorfoses, numa natureza confusa, indefinida e indiferenciada. Uma natureza de impermanências.

Guignard não morava nesta casa

Ela, como a cidade, é que morava nele

Tudo ao revés

Puro encantamento

Primeiro tínhamos o prédio

Depois o consagramos ao nome

Para então ocupá-lo de ideias

O acervo, por último

Não era o mais importante

Principal era tê-lo aqui abrigado

Como ele próprio prendera

A luz e o mistério da cidade

Ou como o menino, que por gostar, 
cativa o passarinho

(afinal ele era um e outro)

Falar de esteios, frechais, barrotes

madres, ombreiras, contrafeitos

seria a retórica do restauro

Importa mais lembrar quem vai fazer viver a casa

Sem de fato, jamais tê-la habitado. ${ }^{12}$

Retomando a presença e a importância de Alberto Burri ${ }^{13}$ para a produção de Libeskind, cabe aqui situar historicamente o movimento informal na arte, que, segundo Argan, "o informalismo é um termo complexo, um tanto ambíguo, empregado com frequência na segunda metade do século XX para designar genericamente obras de aspectos e conteúdos diversos. É significativo que uma tendência não figurativa, baseada na criação-destruição, apareça precisamente no momento em que acaba a Segunda Guerra Mundial, quando se apresenta a possibilidade ou necessidade de criar algo totalmente novo, com autonomia e vida própria após toda uma sociedade ser destruída pela guerra. O que aproxima as várias tendências no conceito de arte informal é a preocupação em destacar aquilo que é fundamental para a sua própria existência: a matéria." ${ }^{14}$

O informalismo como tendência fez sua aparição em 1945, e a arte informal como um todo permitiu uma variedade imensa de direções, - art autre, action painting, tachisme, espacialismo, pintura matérica, etc. -, que dominam o âmbito artístico nas décadas de 1950 e 1960. A denominação de Arte Informal tem sua origem em um termo designado por Michel Tapié, que foi o primeiro a falar da "transcendência do informal" ao explicar a própria pintura. Segundo Cirlot 15 , "o Informalismo, as custas de sua destruição furiosa, oferece um novo

12 Rodrigo Andrade, presidente do Instituto Estadual do Patrimônio Histórico e Artístico de Minas Gerais - IEPHA/MG, entre 1984 e 1987. Poesia publicada no Caderno da Casa Guignard - Ano 1 No. 0 - 1987

13 "O fato novo em Burri é que a matéria, o saco como matéria, ou a madeira ou o papel queimado, etc., é dada como matéria e deve se manter como tal: apenas num segundo momento, na adaptação do observador à obra, é que a matéria consente em retroceder e assumir seu papel predeterminado, e subordinado, na ordem inflexível da obra, como espacialidade escalonada, como cor e fonte de luz" (Brandi). (...) A matéria permanece aquilo que é, mas passa do ínfimo ao supremo grau de valor; torna-se espaço e, portanto, antítese da matéria, sem deixar de ser matéria. Será uma demonstração pelo absurdo: a um mundo orgulhoso de sua lógica, Burri mostra, seguindo a lógica, que há uma lógica que só se pode realizar por meio de um procedimento artístico." In: ARGAN, 1993. p. 625

ARGAN, 1992. p. 542 
interesse pela matéria, um redescobrimento quase místico do sentido do detalhe da força integrada na menor estrutura, na rachadura, na raiz retorcida. (...) Harmonia de proporções não tem significado, nem razão de ser. Atração irracional dos formatos desmesurados em quadros que não se oferecem a contemplação do espectador, mas que o envolvem com uma ânsia de possessão absoluta, obrigando-o a submergir-se no seu universo. (...) Concepção da obra de arte não como representação, mas como elaboração, quer dizer, como objeto real."

Pode-se dizer, portanto, que a arte informal matérica tem a intenção de acabar com uma das questões mais tradicionais da arte: a ilusão. Cria o real da arte e dá-se a realidade do ponto, da linha e do plano, e esse todo é reforçado pela presença inequívoca da matéria. Desta forma, para Cirlot, denomina-se matérica "a uma pintura na qual o maior interesse recai sobre a matéria e na qual as qualidades texturais assumem valor por si mesmas." Ou ainda, nas palavras de Argan, "situando a arte num nível pré-linguístico e pré-técnico, a atividade do artista reduz-se ao gesto, a obra a matéria não formada, mas ainda assim animada e significante. A arte já não tem relação com a sociedade, com suas técnicas e linguagem; é regressão a partir do objeto, existência em estado puro e, como a existência pura é a unidade ou a indistinção de tudo o que existe, na matéria o artista realiza sua realidade humana."

Seguindo a tendência internacional, a abstração irá monopolizar as edições da Bienal de São Paulo nas décadas de 1950 e 1960. O impacto das representações estrangeiras que aportam no Parque do Ibirapuera cria um ambiente propício para as correntes abstracionistas brasileiras.

Libeskind, nas décadas de 1960 e 1970, passa a desenvolver sua pintura com base nos preceitos da arte informal e entra para a história da pintura brasileira - segundo o Dicionário brasileiro de artistas plásticos, de Carlos Cavalcanti, e na catalogação do Instituto Itaú Cultural - como um artista vinculado à vertente do informalismo matérico.

As manifestações diversas da arte informalista irão fascinar Libeskind que, de um ângulo puramente técnico, passa a empregar certos materiais não pertencentes ao âmbito pictórico ou escultórico tradicional e cuja qualidade essencial é de ser, em sua maior parte, composta de detritos - madeiras velhas, pedaços de telas gastas, pregos oxidados, serragem, etc.

Com relação ao processo de elaboração das suas obras, Libeskind utiliza uma grande quantidade de tinta sobre a tela e, a uma mancha inicial, agrega 
diversos tipos de resíduos de materiais como serragem, isopor, areia com di-

versas texturas, pedriscos, borracha, cola branca de madeira, entre outros. Em busca do equilíbrio da composição, gira o quadro várias vezes durante todo o processo. Depois de tudo misturado ainda trabalha com o pincel para a finalização da obra. Os materiais são transformados até o ponto de não serem mais reconhecíveis e passam a integrar um novo contexto que o dota de um significado que se encontra acima da sua própria qualidade e isso contribui, de grande maneira, para outorgar as obras um intenso caráter dramático.

As experiências abstratas plástico-matéricas, foram para Libeskind, sobretudo a partir das décadas de 1950 e de 1960, fundamentais para reiterar a ideia de que toda pintura está relacionada a algo que vimos.

"Nunca parto de um esboço prévio. Sempre lanço uma mancha acidental sobre a tela e daí parto para um processo minucioso de elaboração até chegar a uma composição geral da tela. Esta elaboração é geralmente alterada diversas vezes, sobrepondo-se uma sobre as outras." ${ }^{16}$

As composições com sacos, colagens e distintos materiais presentes nas obras de Alberto Burri (1915-1995), apresentado a Libeskind por Danilo Di Prete, por ocasião da Bienais de Arte de São Paulo, marcaram profundamente Libeskind que, anos mais tarde, também adotaria materiais análogos como elementos de construção técnica dos seus quadros. Processa-se assim uma mudança na pintura de Libeskind, que a partir deste momento começa a rumar do figurativo, herança dos seus tempos de aluno de Guignard, na Escola do Parque, em Belo Horizonte, para a abstração.

"Quando vi um quadro de Burri parece que uma porta nova se abriu para mim, é como que se eu já quisesse fazer aquele tipo de coisa, aquela experimentação, mas não sabia da sua existência"17

Em 1971, Libeskind irá participar de uma exposição individual, na Galeria Documenta, em São Paulo, com 27 telas que evocavam paisagens submarinas - rochedos cinzentos cobertos de uma tênue vegetação azulada, exemplo de células examinadas ao microscópio, formas circulares estriadas de vermelho e branco e agrupadas em torno de um núcleo. A respeito desse tipo de evocação, escreveu Cirlot, em 1959, "cremos que é fator integrante a necessidade do homem atual de encontrar novos aspectos ignorados do real, necessidade 
que o induz a explorar os fundos submarinos e subterrâneos (...) A sede de "ver" algo que jamais tenha sido contemplado é a mesma que empurra os artistas a se aprofundarem desde forma conhecidas a outras menos exploradas para se lançarem a partir destas à assombrosa aventura do movimento no autêntico ignorado."

Burri participa da exposição "Younger European Painters" no Guggenheim Museum de Nova York, e entre 1953 e 54 realiza mostras individuais na Stable Gallery, também em Nova York. Argan relaciona sua obra ao informalismo europeu, descrito assim por ele: "Sacos gastos e rasgados, documentos das dilacerações, das feridas, do sangue que os extermínios, as guerras, os genocídios infligiram a humanidade, e que se encontram entre os momentos mais altos do Informal, por outro lado, que evidencia as possibilidades expressivas da matéria por si mesma, uma matéria inusual para a expressão artística, mas que não elude as características formais e estruturais próprias."

Burri irá ainda ganhar uma das maiores exibições retrospectivas - "The Trauma of Painting”, no Museu Guggenheim em Nova York, com duração de 9 de outubro de 2015 a 6 de janeiro de 2016. Esta exposição foi a primeira nos Estados Unidos nos últimos 40 anos e certamente a mais abrangente já montada, ao explorar a beleza e a complexidade do processo de embasamento do trabalho de Burri, pois a exposição posicionou o artista como protagonista central, singular e único da arte do Pós Segunda Guerra Mundial.

A obra de Burri demoliu e reconfigurou a tradição pictórica ocidental, enquanto reconceituou a colagem moderna, justamente na exploração das técnicas experimentais do artista italiano com o uso de materiais não convencionais.

A obra de Burri, objeto de atenção internacional tão recentemente, acentua o discurso deste lugar entre matéria e não- matéria na relação arte-arquitetura, presente na obra de Libeskind.

A narrativa visual construída no trabalho posiciona a casa de Libeskind como o elemento central, ponto a partir do qual várias associações são estabelecidas, diálogos com o ambiente, com as matrizes referenciais da construção espacial arquitetônica, com a expressão de uma arquitetura através da pesquisa de um esquema de texturas impressas na casa e que reúne em torno dela outros projetos também.

Desse modo há uma constelação de imagens que expressam blocos de texturas, ou "blocos têxteis", para utilizar um termo "wrightiano". Aí estão colocadas toda a sorte de pedras no tratamento de muros e de planos que estabelecem uma relação bastante aproximada com as experiências com materiais diversos nas investigações plásticas de Libeskind. 
Por outro lado, há uma constelação de imagens que expressam as trans-

parências e toda a sorte de elementos que tratam o material "liso", transparentes ou não, com experiências cromáticas riquíssimas como os azulejos com desenhos e grafismos (que convoca o artista gráfico Libeskind), cerâmicas vitrificadas, superfícies acrílicas coloridas, ou ainda as pedras lisas, roladas. Aqui, Guignard também surge metaforicamente, pois conseguiu, segundo Naves, como poucos, criar uma unidade original entre espaço, superfície, tema e textura. ${ }^{18}$

Também há as madeiras, os painéis e o aspecto gráfico que também aparece no trabalho com esse material.

Um ponto de convergência nas trajetórias de alguns arquitetos modernos era a busca por propostas que integrassem outras manifestações artísticas aos seus projetos. Valorizavam a componente estética, como um ponto emocional agregado, talvez como tentativa de superação da resposta meramente funcional. Assim um artista plástico poderia imprimir um "selo" qualitativo e distintivo aos seus projetos.

O processo artístico, e por consequência a obra de arte, para Libeskind, não é um elemento adicionado como apontado acima. O resultado da sua produção se revela como convergência e simbiose estabelecido pelos fundamentos do momento conceptivo entre arquitetura, pintura ou desenho gráfico originário de um conjunto coeso. A sua formação em desenho e em pintura ultrapassou o mero exercício circunstancial ou a educação extracurricular comum às gerações com recursos.

A casa do arquiteto é síntese dessa reunião e a abordagem realizada no trabalho, que tem como objetivo recuperar as peças matrizes do universo de formação do arquiteto, sugere que - através da liberdade colocada no trânsito do ir e vir temporal, assinalada pelos momentos em que a casa está habitada ou está vazia - Libeskind tenha um lugar ímpar no conjunto da produção da arquitetura moderna brasileira. Este não é um lugar de exceção ou algo que possibilite reconhecê-lo imerso num campo extraordinário ou alienígena, mas, assim como Guignard, afirmar que ele construiu a sua própria lógica artística, que, numa primeira aproximação e para efeito de compreensão inicial, sugere pertencer a um grupo atestado como aquele desvinculado da corrente brutalista paulista, de viés político, ou ainda, que estivesse ligado às manifestações culturais populares.

Nesse sentido, Libeskind parece então estar muito mais próximo das correntes norte-americanas, e isso não deixa de fazer sentido por uma lado, 
haja visto as presenças de Wright e Neutra, mas também as possibilidades de reunir alguns arquitetos paulistas em torno da sua produção - Rino Levi, Oswaldo Bratke e Miguel Forte. Mas, por outro lado, as aparições cromáticas e materiais com toda a sorte de texturas, brilhos, opacidades, ranhuras, grafismos, transparências presentes nas suas obras são advindas de outras regiões criativas que se fundem e constroem ativamente a sua arquitetura, o que sugere que este arquiteto-artista só possa ser de fato compreendido através da colocação de que a sua obra é resultante da interlocução entre arquitetura e arte, mas que isso ultrapassa uma compreensão sintática e que aponta para o campo simbólico.

Nessa conjuntura de análise estrutural, só parece fazer sentido uma abordagem da sua obra realizada por processos ou métodos de análise onde a realidade dos seus projetos vai se conformando a partir de dados aparentemente isolados, mas que, ao contrário, fazem parte de um todo maior, e este todo é a sua própria arquitetura, resultante das inúmeras formas interdependentes de associação de tais elementos. Assim, o ciclo se fecha e a noção de que "tudo é arquitetura" revela Libeskind através da sua casa, uma autobiografia com muitas camadas que resiste pela memória, ainda que a casa esteja vazia.

Posto que a sua casa o explica, assim como as bibliotecas de Benjamin e Mangel. ${ }^{19}$

19 Nas operações inversas de desempacotar a biblioteca - no caso de Benjamin, e de embalar a biblioteca, no caso de Mangel, o que se observa é a relação da vida entre os artistas com os objetos testemunhas da sua existência. "Muitas vezes senti que a minha biblioteca explicava quem eu era, me conferia um eu sempre em mudança, que se transformava constantemente ao longo dos anos". MANGEL, Alberto. Embalando a minha biblioteca: uma elegia e dez divagações. Trad. Rita Almeida Simões - 1'. ed. Lisboa: Tinta da China Editora, 2018. p.15. 



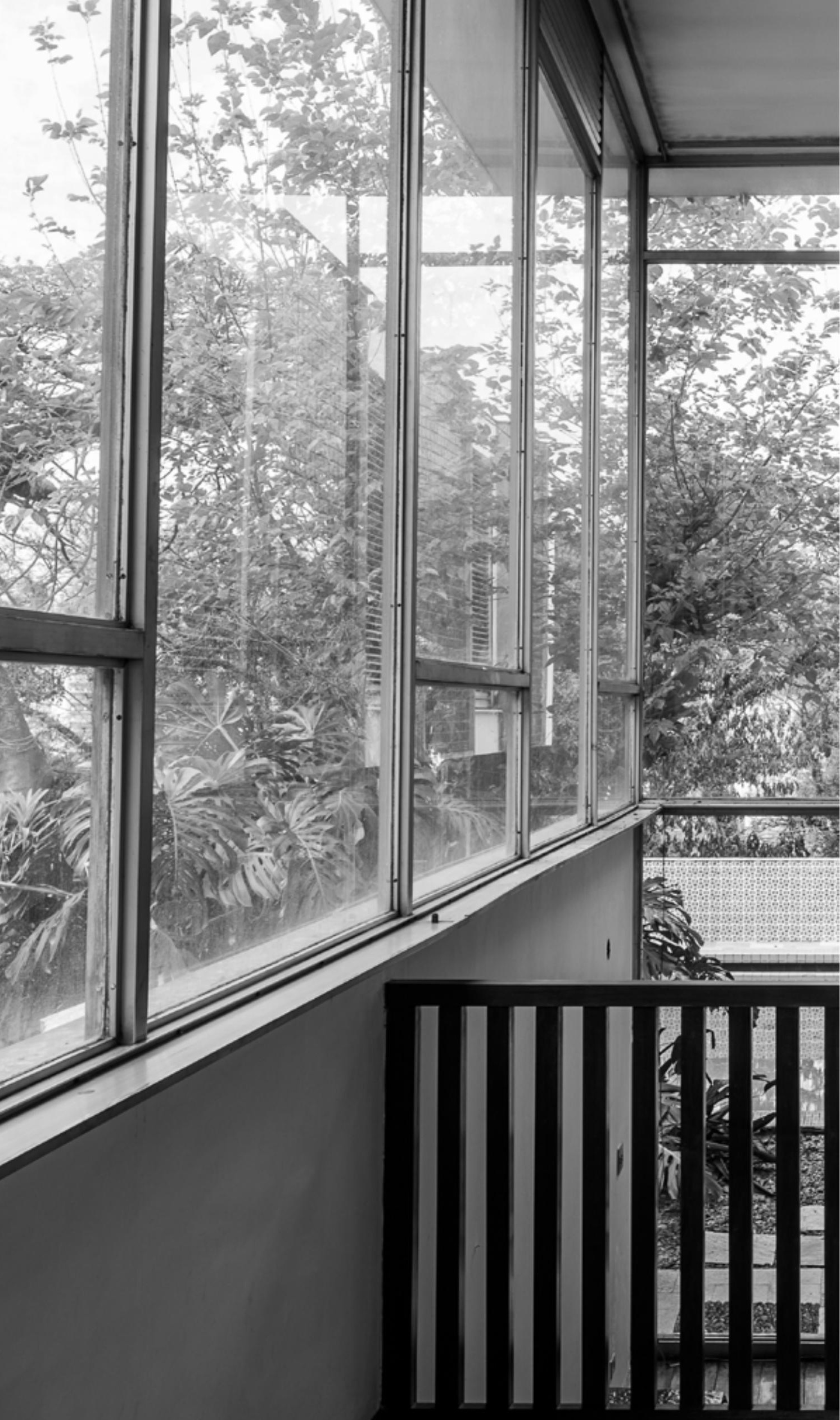




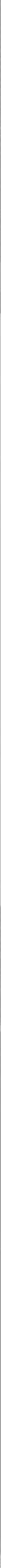


INTERLÚDIO: A CASA VAZIA OU A MORTE DO ARQUITETO 
"É preciso sustentar que a palavra cria o fato, coloca-o de pé, e ao mes-

mo tempo que o fato silencioso é coberto pela terra. O fato é sempre a resistência entre o que o ato de falar arranca e o que a terra enterra. É um ciclo do céu e da terra, da luz exterior e do fogo subterrâneo e, principalmente, do sonoro e do visual, que não reconstitui jamais um todo,

mas constitui a cada vez a separação das duas imagens, ao mesmo tempo que o novo tipo de relação entre elas, uma relação de incomensurabilidade bastante precisa, não uma ausência de relação."

Gilles Deleuze

Eu só vi poesia ali quando voltei na casa em 2016. Quando ela estava vazia. Quando Libeskind me acompanhou sem matéria. Sua presença pairava em tudo, exalando em cada desgaste o seu próprio rastro.

Havia um silêncio insuportável, mesmo que todas as vozes da sua obra ecoassem naquele lugar. A casa vazia não era em nada parecida com a ideia da casa concebida e muito menos com ela preenchida pelos seus objetos em vida. A casa vazia parecia com Libeskind. Decrépita, rasgada, descolorida. Tinha cheiro de madeira velha. Tinha lodo na piscina. O piso manchado e descolorido pelo sol que atravessava sem piedade as grandes aberturas envidraçadas e desprotegidas.

A casa era pesada apesar do nada que ali estava contido. O peso grave era do tempo que em tudo imprimia uma importância insuportável, que desgarrado da mácula moderna agora desmaterializara tudo. A casa era uma rua que eu não queria atravessar. A piscina repleta de folhas, água turva e imprecisa, lembrou-me Guignard e a sua nuvem. Juventude em precipitação do jovem Libeskind, tudo a despencar ferozmente em força nova estava ali.

O bar era uma caverna. E Libeskind estava lá. Era de lá que o som da sua voz lenta e descompassada chegava aos meus ouvidos assim meio mineiro e meio paulista. Doente e cansado. Mas surpreendentemente atento para segurar com firmeza um copo de whisky. Eu desci as escadas com cuidado, invadindo o lugar privado da arte, seu estúdio de pintura. Vazio e estranhamente limpo, como jamais teria sido. Por que logo ali o que insistia em sobressaltar aos meus olhos era aquele piso azul tão brilhante que nada revelava das suas experiências desorganizadas e explosivas? Por que um espaço tão controverso? Seria assim em você, Libeskind? Um pêndulo inebriante entre uma coisa e outra que não te deixava em paz? Tudo na casa é ambiguidade entre permanência e movimento, entre claustro e transparência, entre vida e morte. 
A casa estava impiedosamente fria, apesar do mês de abril de céu azul, quando me encontrei com você impregnado nas paredes, tatuado nas cerâmicas, colado à sua lareira. Você estava lá e não me deixou em paz. E eu precisei voltar a falar de algo que não era precisamente a casa e nem propriamente você. Eu precisei me aproximar da insuportável necessidade de falar da arquitetura sem falar da arquitetura. Ou do sentido que percebi na arquitetura através do conjunto latente da sua obra na sua casa.

Eu me esfreguei naquelas paredes com os olhos e mergulhei naquela piscina pra falar com você.

Todos os seus telefonemas eram de desespero, você sabia que a vida estava nas últimas gotas, mas que tinha uma história pra ser contada através da sua casa. Foi um pacto silencioso que travamos, um daqueles arranjos leves e aparentemente descomprometidos que o tempo inexoravelmente nos cobra.

Eu invadi a sua casa com fome de fazer uma dissertação de mestrado nos anos 2000 e não poderia saber que nela morava a síntese da sua obra completa. Sobrevoei a sua vida pousando aqui e ali para colher os capítulos da sua biografia. Fui a Minas Gerais em 1940, andei pelo parque com Guignard e flutuei nas suas igrejas "levitantes". Sentei-me entre Juscelino e Niemeyer para compreender Pampulha e toda essa vontade de BH ser moderna. Almocei com Rino, Artigas e Bratke no IAB dos anos 1950 para cavar o Conjunto Nacional. Capítulo à parte que revirou seu futuro e selou seu destino. Nem no sonho mais ousado poderia imaginar que carimbaria 150.000 m2 construídos em uma quadra da Avenida Paulista assim tão precocemente. Mas o imponente edifício multifuncional também está lá na sua casa, ele imprimiu uma condição de maturidade antecipada para sua obra.

Peregrinei por doze das suas casas, redesenhei seus projetos, analisei as suas plantas, montei e desmontei possíveis relações entre elas, mas sem desconfiar que todas habitavam em você.

Naquela época você andava às voltas com uma perturbação. Eu era a sua confidente em longas tardes de pesquisa junto ao seu acervo. Às vezes a saúde permitia mais diálogo, às vezes era puro silêncio no remexer dos papéis. O tempo era seu, o que comandava o ritmo era a sua disposição. Tudo sempre andou conforme o seu controle, até quando este estava à sua própria revelia.

Havia alguém querendo roubar a sua obra. Essa era a sua desconfiança ainda em vida, alguém que rondava a sua casa, e você ansiava em sossegar.

Johnnie Walker também perambulava por ali, o cão que não poderia ter outro nome, e não poderia suportar a sua partida, então delicadamente se retirou antes de você. 
E aquele seu motorista? Eu me lembro dele, que me recebia todas as vezes que eu ia te visitar. Havia um certo formalismo que se desmanchava quando começávamos a falar de arte e de arquitetura. Você preferia falar dos outros artistas do que de si mesmo. Sim, você apenas queria conversar sobre arte e sobre seus amigos, a verdade era essa. Você quase não falava de arquitetura. Gesto delicado, que guardava a austeridade mineira simples e gentil por trás do grande arquiteto do Conjunto Nacional. Sim, há uma imponência na relação com a super escala daquele edifício que sobrepujou a você mesmo. De modo que sempre havia uma explicação a ser dada: "David Libeskind, o arquiteto do Conjunto Nacional"... Sua obra era mais conhecida que você. Isso te incomodava? Não sei dizer exatamente, mas sei que a sua obra esperava o registro que foi feito. E agora a sua casa precisava assegurar que nada fosse levado, que este ladrão oculto dos seus delírios não desaparecesse com os seus feitos.

Esse foi o Libeskind que conheci pessoalmente. $\mathrm{O}$ jovem arquiteto ficara impregnado em todas as imagens e fotografias que manuseei.

Assim que tenho duas memórias: a do convívio com o já cansado Libeskind e suas histórias do passado e dessa casa vazia que me revelou, de fato, a arquitetura.

Rastro e memória numa tábua desfigurada e rompida como num quadro de Burri. $\bigcirc$ que estava desgastado e dilacerado pela guerra entre a vida e a morte e tudo o que está entre uma coisa e outra é o tempo percorrido e sedimentado nessa casa.

Libeskind não se mudaria para outra casa. Ele habitou a casa até a sua morte. E isso claramente se revela como evento absoluto: a imaterialidade deste fato denota paradoxalmente a permanência, a presença imanente.

E só pode haver um compositor que cabe aqui: Beethoven. Porque em tudo na casa há rigor e explosão. Síntese da construção clássica em estruturas familiares. Emoção grave e pura técnica. Sem excessos, transparência e controle, revelações cromáticas e tácteis.

E como a surdez em Beethoven, Libeskind perdeu a sua fonte de controle mecânico e não podia mais desenhar. A ele restou organizar a sua própria obra.

E tudo acontecia naquela casa. As fontes primárias espalhadas na mesa do escritório ainda eram para mim um punhado de informações desconexas.

O sentido só chegou com a casa vazia. A existência que revela um destino. Uma flutuação que só percebi na rotação entre o bar e a lareira e na força vertical da relação escritório e sala de jantar. Quando vi paredes lavadas sem os quadros e percebi a força dos planos com seus mais variados tratamentos. 
Um desbotamento que torna imprecisa a tonalidade. Ruídos visuais que perturbam a ordem impecável, mas que permitem a aproximação com a imprevisibilidade da vida. A força incrustada na casa estava independente de qualquer aparecimento. A casa já era sua própria biografia. O fato já existia por si. A morte não era nada. Tudo estava lá, porque houve um antes. Naquele dia pude compreender essa conexão temporal da casa. Ela estava em mim enquanto fato vivido. Seria essa a tal da Fenomenologia?

Libeskind estava lá sentado à beira da piscina, orgulhoso da obra de arte mais vultosa da sua coleção: Banho de Sol, de Brecheret.

Por ali deveriam brincar os filhos que ele podia vigiar do ateliê através do visor com vista para a água da piscina. A vista não seria nítida a partir daí.

Seu ateliê estava na memória e na vida. A única vez que visitei, em sua companhia, o seu tanque de mergulho, encontrei um jacaré "matérico" que espreitava sobre o cavalete. Sua última realização em pintura. E tudo era líquido assim como as gotas de tinta que Di Prete jogava nos guarda-chuvas dos transeuntes que passavam pela rua lá embaixo. Ou aquela história do Guignard na banheira, embriagado de tanta cachaça. Tudo isso num caldo submerso, oceânico, aquático, amniótico e flutuante. A base da sua casa era impermanente. Era para lá que você descia para sustentar paradoxalmente a sua arquitetura?

A centralidade da posição do escritório era perturbadora e denunciava que, absolutamente tudo, passava por ali. Tudo passava por você. Sempre. Controle do percurso da vida e da obra. Ainda que ali se implantasse o caos dos seus papéis em orgia produtiva - e essas são as minhas lembranças mais nítidas. Uma caixa suspensa em muito boa companhia. Assim eu definiria o seu escritório: livros, agendas, pastas, porta-retratos, desenhos e documentos que garantiam que a vida era importante. Aquela falsa importância dos contratos.

Eu me cansava daquelas suas pastas verdes de elástico que você deixaria eu retirar toda semana dali. Eram três pastas por vez, o nosso combinado. Nelas eu poderia encontrar de tudo. E o mais impressionante eram as fotos do Moscardi misturadas com aos seus desenhos impecáveis. Agora tudo isso já virou catalogação de biblioteca, mas um dia estava lá adormecido e desesperado, porque continha a sua luta contra o tempo que a cada dia o arrancava mais um pouco da vida.

Eu posso ouvir a sua voz lânguida e macia me explicando aquela foto. A mais impressionante de todas. Aquela que por descuido meu caiu de dentro de um livro e foi fazendo um vôo leve até pousar no chão.

Era a II Bienal em São Paulo e Mies, sim, o Van der Rohe, em pessoa, fora clicado olhando a maquete do Conjunto Nacional. 
Ainda penso naquela foto do Mies preso ali dentro de um livro. Após a sua liberdade surgiram também o Neutra, o Wright...

Há uma elegância discreta na obra de Libeskind que também convocava Bratke, Tenreiro, Bruno Giorgi, Stokinger. Era tudo de uma tonalidade profunda, firme, consistente e divinal, como em uma sinfonia, que vai se conformando aos poucos, convocando cada instrumento num conjunto harmônico. Amigos, contemporâneos de vida e de obra, estes personagens eram sempre comentados por Libeskind numa importância a privilegiar o convívio, as obras trocadas aqui e ali por quadros e esculturas. Ao me revelar este conjunto de referências, ele falava dele mesmo, num sentido figurado, talvez como forma de burlar a autodescrição.

Mas nas esquinas da sua casa também pairava um Goeldi com suas sombras de escuridão incertas. Penumbra de solidão em cada fragmento cediço, dos projetos que não vingaram, da vida pessoal posta de lado, do descarrilar incontrolável da vida e das suas variantes que rompem em pavores cíclicos e penetrantes. E inevitavelmente um dia você me falou: "agora só recebo telefonemas de convites para velório. Meus amigos se foram."

Ali você já era um desencaixe no mundo, peça solta em vagas cenas de um tempo paralelo com a vida no correr de um fio, imersa num (quase) póstumo.

Convocar esta casa vazia e todos os seus extratos pode ser uma decisão perturbadora, pois sempre há algo que deve ser dito, um gesto que revela a exaustão, alguma verdade oculta fincada na casa-vida. Libeskind se comunicava com o mundo através da sua casa, o seu jeito de estar no mundo, e, portanto, a sua fala é a fala interior desta casa. O tempo e a casa selaram uma união, que rompe com a lógica linear e flerta com a imposição das memórias (suas e minhas) que se confundem, propositalmente rompendo em alguns momentos com qualquer verossimilhança. Há um pouco de fantástico nessa narrativa, assim como há claramente colocado o desmoronamento lento da casa em analogia com o desaparecimento do ser e suas dependências emocionais e suas ambições. E quando é anunciada a morte, nasce um outro ser. A casa que ainda está lá, como massa a ser colocada no forno numa mistura de tantos aromas e sabores, também às vezes com gosto bloqueado, gosto travado, e tudo nela relativizado pela sua existência ímpar.

As ausências se estabelecem na mesma proporção das presenças. Não existir enquanto fato material não consegue afogar a matéria ou a memória. Derrete-se cada vez mais essa dependência do existir enquanto realidade existencial. Na desaparição de Libeskind o fato da sua casa ainda se tornou mais 
forte, testemunho da dilaceração na crença de uma liberdade de expressão criadora total. Um anti-academicismo perturbador para o qual não há remédio nesse caso.

Convocar para si este espaço libertador requer um preço, semelhante àquele pago por Guignard, recluso e perdido entre as ruas de Ouro Preto, vagando ele mesmo dentro do seu próprio recorte de paisagem.

E tudo aquilo que não foi programado, o que com o tempo se transformou e adquiriu novos contornos, desmonta na casa vazia a ideia de um marco inocente, exemplar arquetípico da produção de um tempo circunstanciado. Este lugar íntimo e por vezes inóspito, com exatidão do seu significado, ou aquilo que enquanto estrangeiro é mal acolhido, reedita seu valor construído e colabora para que em todas as situações de construção sobre si mesma concebida, recém-inaugurada, habitada com a família, habitada em solidão e finalmente vazia - seja testemunha de um hábito - habitat.

Sua expressão teve afortunadamente um lugar para se desenvolver na possibilidade de se expandir em diversas direções, imerso em um universo predominantemente masculino, retrato da inexistência maternal.

Vi um vaso de flores numa foto de época em que a casa foi habitada pela família. Ali houve uma mulher, algum dia, que conseguiu silenciosamente penetrar no predomínio dos homens arquitetos e artistas e no seu mundo difícil envolto em conflitos sociais, culturais e políticos, que lhes foram impostos ao longo dos anos.

E não encontrei em mais nada a presença do sentido da palavra feminino nesta casa.

Ainda que a sala de jantar insinue um cortejo com o escritório, porque há a contínua troca de olhares entre eles, a mim sempre pareceu ser este o lugar estranhamente infértil da casa. Ali estava ausente a família, as refeições que trazem o motor vital da existência.

Tudo que se devora, comida dos próprios olhos lutava anacronicamente com a impecabilidade deste espaço. Algo que talvez tenha se preservado melhor devido à escolha dos materiais ali empregados, apresentando pouco desgaste, ruptura entre passado e presente. Assim a sala de jantar parecia o único espaço congelado da casa, inerte às ações do tempo. E se colocava o embate entre as ações de um e de outro ambiente, mesmo esvaziados das suas atividades de outrora. Havia um motor trabalhando que foi a última máquina desligada na casa a partir da ausência de Libeskind. Era o escritório, porque também se colocava em posição central.

Quando eu voltei, na casa vazia havia latência, eu ainda encontrava incu- 
bação, porque não há uma forma definitiva em algo que se expande no tempo,

contrária, ela mesma, à sua forma geométrica e arquitetônica.

Posso assim chamar a arquitetura da casa com todos os princípios nela implicados, de desdobra. Subjetivação do verbo, porque é coisa que existe como síntese de um acontecimento consumado.

Retornar à casa vazia foi para mim (e em mim) um impacto arquitetônico emocional, muito mais relacionado a um ato e não a um objeto ou elemento propriamente visual. E aqui se dá o exatamente oposto, o substantivo volta a ser verbo. Aproximar, entrar, olhar, percorrer. Viver e morrer nesta casa eternizam a sua existência.

Não se trata de enfeitar a morte com imagens, mas de mostrar aquilo que é próprio do processo de negação, as imagens podem "ajudar" as palavras, fazer ouvir, no presente, o sentido vivo e atemporal do que elas dizem.

Talvez a arte seja o presente de uma ausência e a partir dela seja possível construir a visibilidade do espaço onde ele é audível. Porque nisso tudo há um limite para aquilo que é visível, ou ainda um limite para aquilo que pode ser lembrado através de imagens, cenas e lugares que se colam na memória e transitam de um lado para o outro, sem razão. Mas há um privilégio, da esfera de um significado indeterminado nesse procedimento de transformar a vida e sua banalidade intrínseca em matéria de arte absoluta. A casa vazia apresenta através de mim um olhar que transita entre o consciente e o inconsciente. E o processo de subtração da vida objetiva contraposto ao registro documental oficializa a memória, pelo simples fato de existir um modo de ser cotidiano.

Nas suas perturbações também havia um Libeskind indignado com o lugar da arquitetura na imprensa até aquele momento, na ausência das discussões importantes sobre a vida das cidades e dos edifícios na cidade como elementos que deveriam ser indissociáveis da própria discussão do cotidiano. Porque para ele fora sempre assim e este tempo perdido revelava o lugar também perdido da arquitetura enquanto cultura. E isto não era pura retórica de arquiteto modernista. Era força motriz para Libeskind. Então ele falava: "Não me refiro a esse caderno sobre cidades, generalista, ou quando muito voltado para a publicidade dos novos empreendimentos. Refiro-me ao caderno sobre arquitetura que tinha nos velhos tempos, a gente falava sobre arquitetura, a gente discutia, sabe?"

Como eu tornaria sensível o inumano e a não presença?

A pausa e não o fim. Um entreato.

A história não conta nada, o que me interessa é este som do ranger daquela porta, ou ainda aquele vento que perturba a água parada. O que me 
encanta são as arquiteturas entre os pedriscos, a turbulenta massa que compactou tudo, a lisura de um comportamento inesperado que ao escorregar diretamente se choca com a viga metálica.

Rompe-se, assim, a carne, que há tempos mutilada ardia para escapar do enquadramento da tela. Todas as arestas que insistiram em manter a ebulição em cativeiro. A ingenuidade também ficou morando lá, escondida atrás de uma cortina.

Pode voar naquele balãozinho "entre-montanhas", que agora a sua casa está segura. 


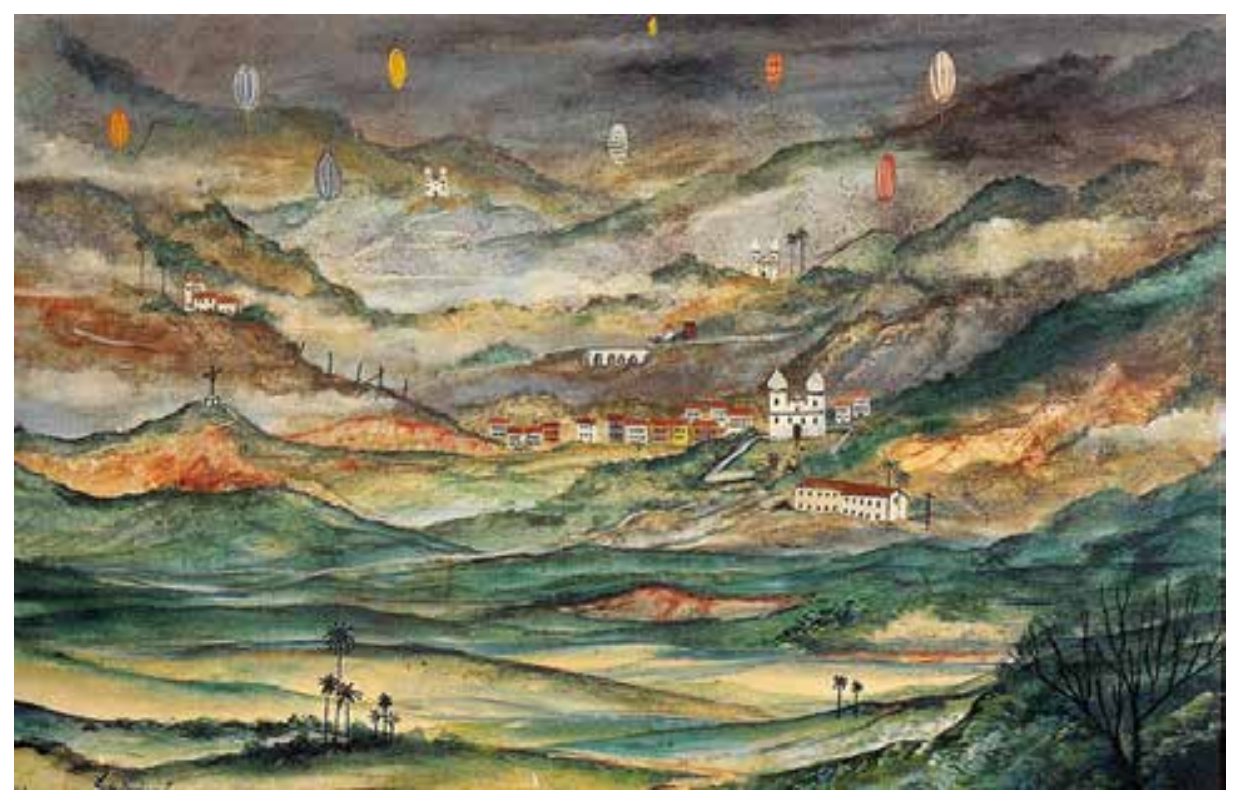



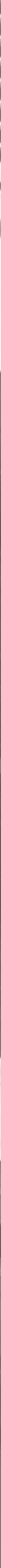


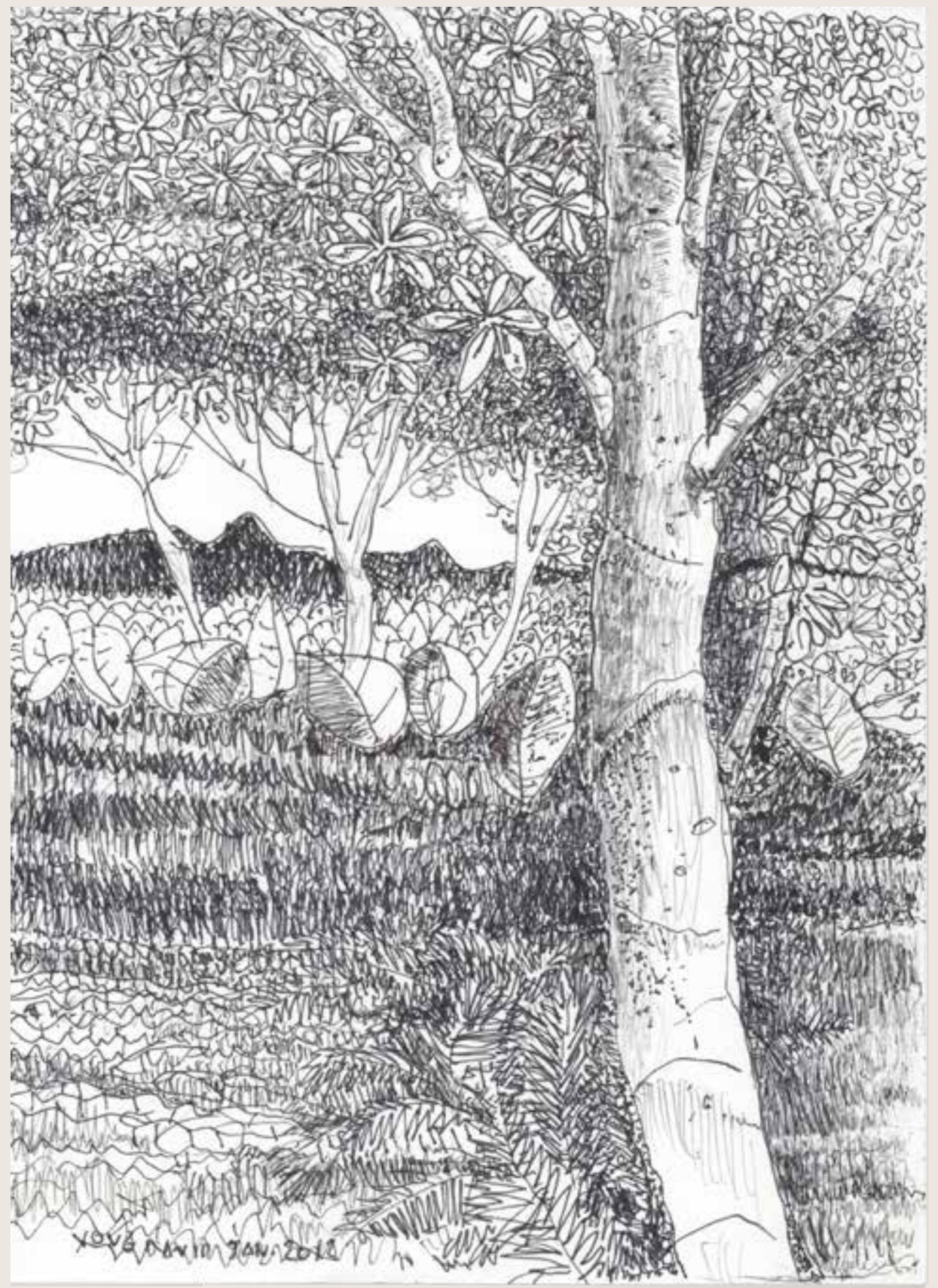


ÚLTIMO ATO: ARQUITETURA DO DESENHO 
No final da vida, num tempo de absoluta impossibilidade de fazer arquitetura ou pintura, Libeskind irá convocar, como último recurso expressivo, o movimento involuntário provocado pela doença para reinventar o seu desenho. A nova fórmula ainda revelará o rigor da estrutura arquitetônica e geométrica da composição do quadro combinado às texturas das experiências livres e táteis uma inequívoca mobilização da sintaxe arquitetônica no ritmo e na construção dessa arquitetura gráfica.

Em uma singela coleção de pouco mais de dez pequenas gravuras realizadas no ano de 2012 - dois anos antes da sua morte - Libeskind revela a sua síntese nos desenhos adormecidos no fundo de uma gaveta do seu escritório, que seriam as últimas testemunhas de uma casa habitada por um arquiteto-artista moderno que se formou na certeza de que a arte poderia resolver o mundo, porque deu conta do seu universo interior, deixando como derradeiro recado a contribuição para a produção brasileira através de uma leitura ao revés, daquilo que não é o fim, mas que permeia as incertezas que acompanham os processos e que ultrapassam os limites da arquitetura num discurso não linear.

Recupera-se, numa gravura de uma paisagem natural, os vestígios de uma vida, ainda que agora falte nessa casa o hálito vital, pois passa o tempo e o impacto das existências abrigadas começam a ser notadas por um nova coesão: a casa sofre uma sutil transformação, agora ela é o elo - início e fim - e a razão para tudo aquilo que é imprevisível, pois "a arte é um fazer e se faz aqui e agora, não ontem ou amanhã; e faz objetos, que o tempo não engole e que permanecem presentes". ${ }^{1}$

Guignard segura a mão de Libeskind e dirige o traço preciso, rigoroso, que cria sulcos no papel. Tudo feito na grafite dura, mas também feito no gesto, porque a mão do desenho é o pulso moldado no olho, no ritmo sincopado que alterna tempos fortes e fracos como a respiração do final da vida.

As árvores regulam o eixo vertical do desenho e o sentido de ligação entre terra e céu. Seus troncos criam o módulo estrutural, guiado pela arquitetura que organiza a composição e ordena a divisão das partes da figura para que a visão se distribua por completo. A arquitetura informa esta paisagem de 
que há uma lógica assimilada pela orientação moderna que dirige a criação. As

camadas horizontais regulam as linhas de vegetação plantadas no solo - fundação do lugar e do chão onde todos os elementos do desenho se ancoram.

Ao fundo há montanhas escuras, que delicadamente sinalizam o plano horizontal de divisão entre as colinas e o céu. Este pequeno pedaço de horizonte é uma ausência calculada no desenho, a pausa para que tudo ao redor possa saltar em contrastante energia - folhas e flores que se agitam como matéria viva - texturas sobrepostas reveladoras de um conjunto vigoroso e expressivo a partir da unidade multiplicada e da lição do ornamento delicado posto na medida justa.

As relações entre parte e todo estão expressas através das linhas que constroem a perspectiva, a luz e as sombras, conferindo movimento a esta arquitetura de planos tão exatos no apuro do tratamento zeloso de cada elemento, que revela o seu pormenor - exercício da reta e da curva expresso por meio de um repertório gráfico que afirma o domínio da linguagem. E neste ponto o discurso do desenho revela o caráter da arquitetura, a fala que é base da substância da vida e da obra do artista.

A mão de Libeskind agora se liberta e todo o seu corpo está em harmonia pela última vez olhando para a paisagem-síntese. Foram-se o livro e a cadeira, os quadros e as luminárias. Foram-se também todos os ruídos embalados numa caixa de papelão.

Agora há dois homens que caminham na distância das montanhas entre os tempos: o arquiteto jovem e o maduro reunidos num resquício de papel, último vestígio da sua presença na casa - reverberação perene da memória. 

APÊNDICE: DESENHOS ARQUITETÔNICOS DA CASA 


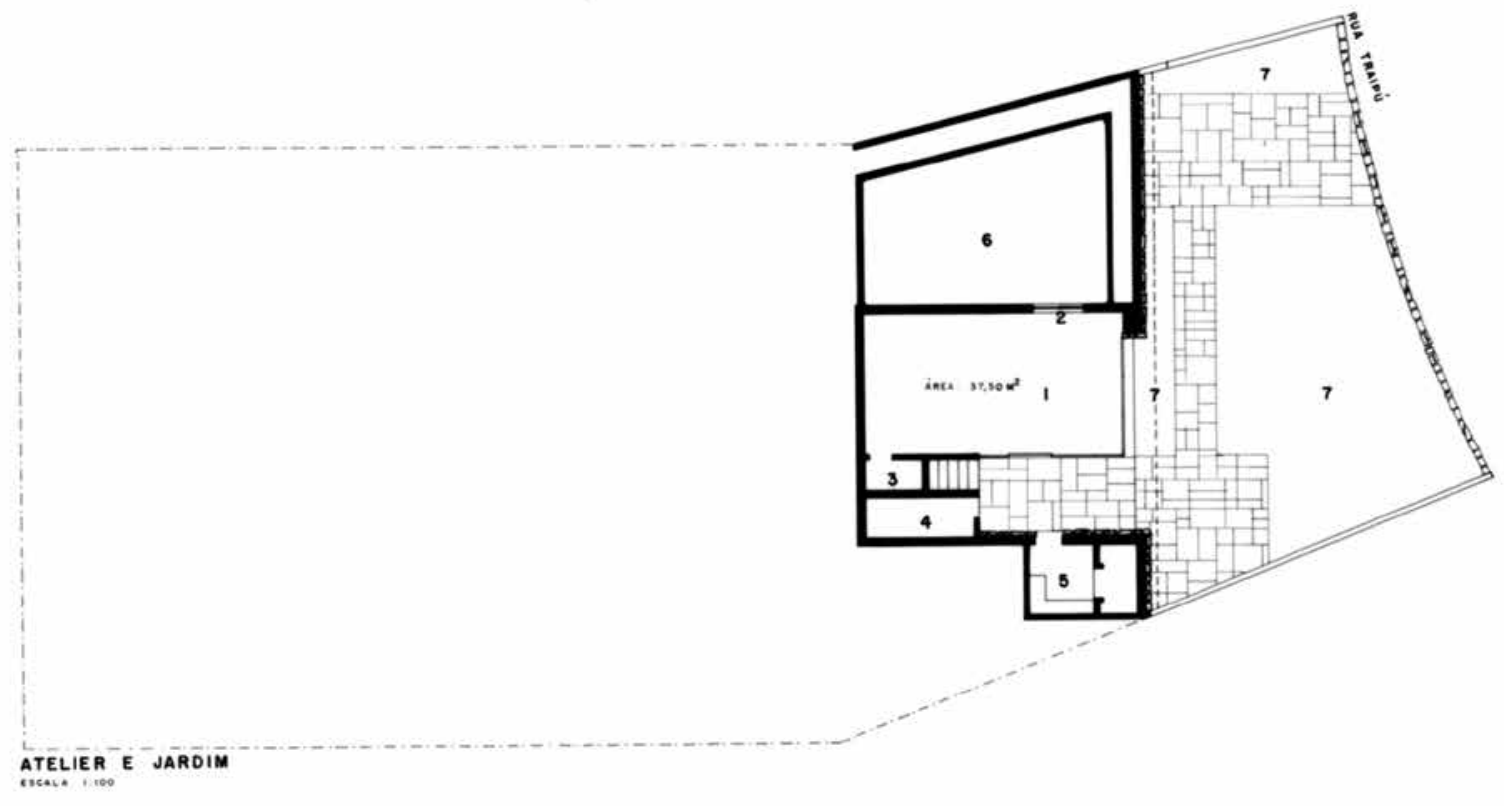

\section{legenda}

1. atelier de pintura

2. visor

3. armário

4. instalação sanitária

5. laboratório fotográfico

residência David Libeskind

6. fundo da piscina

7. jardins

planta original atelier e jardim sem escala 


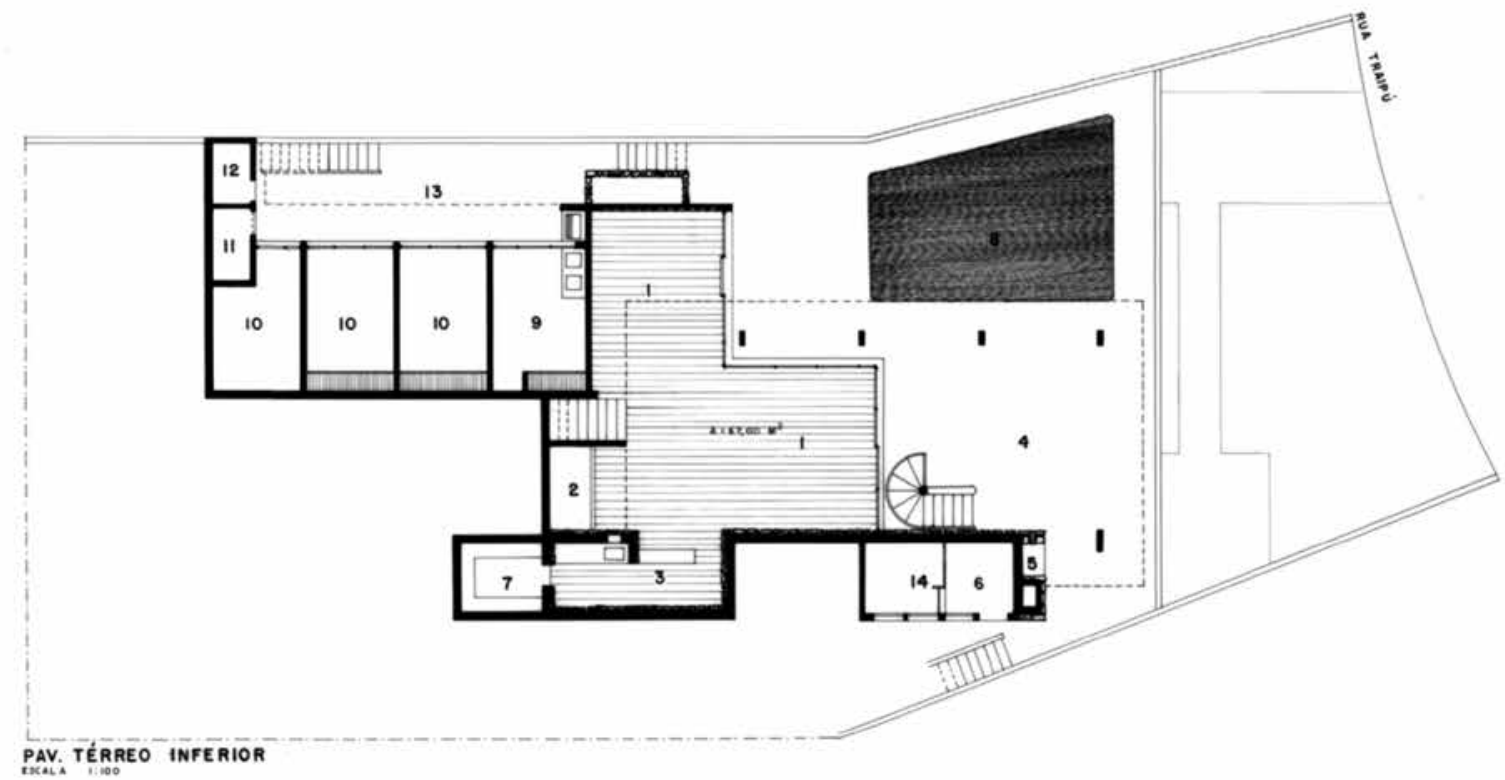

legenda

1. sala de estar 2

2. lareira

3. bar

4. jardim coberto

5. churrasqueira

6. depósito

7. adega

8. piscina

9. lavanderia

10. dormitório serviço

11. banho serviço

12. gás

residência David Libeskind

13. páteo de serviço

planta original térreo inferior

14. casa de máquinas

sem escala 


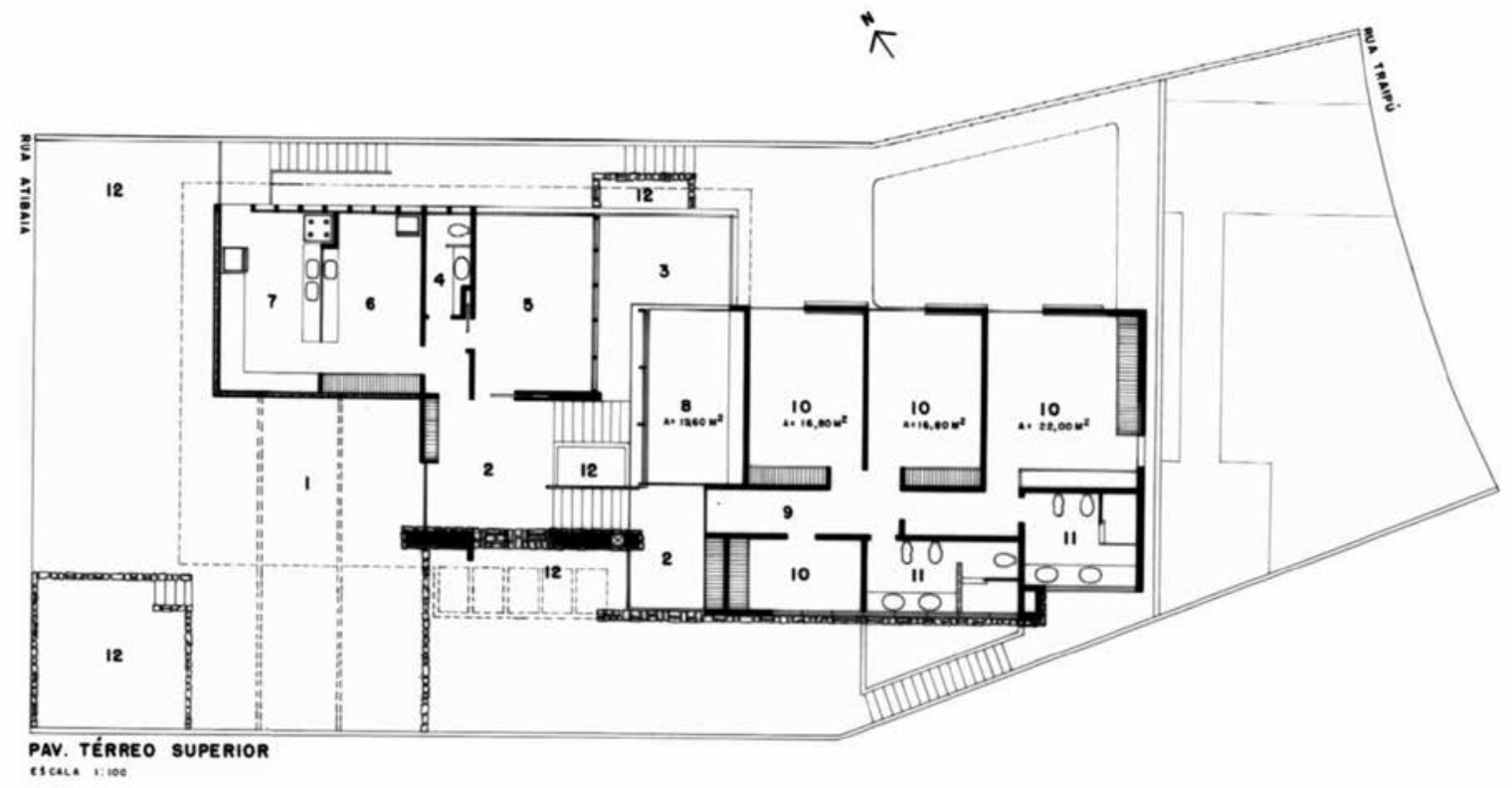

legenda

1. garagem

2. vestíbulo do acesso principal

3. vazio da sala de estar 1

4. lavabo

5. jantar

6. copa

7. cozinha

8. escritório

9. circulação

10. dormitórios

residência David Libeskind

11. banhos

planta original térreo superior

12. jardins sem escala 

LEGENDA E CRÉDITO DAS IMAGENS 
IMAGENSDE

ABERTURA DE

CAPÍTULOS

\section{Pags. 10 e 11}

Residência David Libeskind (1961)

Vista da garagem e acesso

principal da casa

Foto: Karen Balsevicius Evangelisti (2016)

\section{Pags. 22 e 23}

Residência David Libeskind (1961)

Área externa coberta para acesso

do ateliê

Foto: Karen Balsevicius Evangelisti (2016)

\section{Pags. 28 e 29}

Residência David Libeskind (1961)

Vista a partir da sala de estar 2 (contígua ao bar) para a área da piscina.

Foto: Karen Balsevicius Evangelisti (2016)

\section{Pags. 86 e 87}

Residência David Libeskind (1961)

Muro da piscina - azulejos -

desenho/ grafismo de David

Libeskind

Foto: Karen Balsevicius Evangelisti (2016)
Pags. 128 e 129

Residência David Libeskind (1961)

Bar - Joaquim Tenreiro, adega,

muros de pedra, piso e forro de

madeira

Foto: Karen Balsevicius Evangelisti (2016)

Pags. 176 e 177

Residência David Libeskind (1961)

Vista a partir da sala de jantar -

volume do escritório acima, à direita

Foto: Sissy Eiko

Pags. 188 e 189

Residência David Libeskind (1961)

Piscina e elevação lateral da casa

Foto: Karen Balsevicius Evangelisti (2016)

Pags. 194 e 195

Residência David Libeskind (1961)

Escada de acesso para ateliê

Foto: Karen Balsevicius Evangelisti (2016)

Pags. 234 e 235

Residência David Libeskind (1961)

Garagem - porta principal e vigas metálicas

Foto: Sissy Eiko 
PRIMEIRO ATO:

UM PROJETO DE

ARQUITETURA

1

Residência David Libeskind (1961)

Painel de azulejos - muro da piscina

Foto: Karen Balsevicius Evangelisti (2016)

\section{2}

Residência David Libeskind (1961)

Elevação lateral - abeturas dos

dormitórios - painéis em cerâmica

vitrificada

Foto: Karen Balsevicius Evangelisti (2016)

\section{3}

Residência David Libeskind (1961)

Elevação frontal - vista a partir da Rua Atibaia

Foto: Karen Balsevicius Evangelisti (2016)

4

Residência José Felix Louza,

Goiânia (1952)

Vista a partir da esquina - painéis em elemento vazado, azulejos e tijolos

Foto: David Libeskind (1952)
5

Residência David Libeskind (1961)

Vista externa a partir da garagem tratamento das superfícies em pedra

Foto: Karen Balsevicius Evangelisti (2016)

6

Residência David Libeskind (1961)

Pátio externo ligado ao ateliê elevação da Rua Traipu

Foto: Sissy Eiko (2014)

7

Residência David Libeskind (1961)

Pérgola sobre pátio e jardim do vestíbulo da área íntima

Foto: Bebete Viégas

8

Residência David Libeskind (1961)

Escada de acesso ao ateliê

Foto: Sissy Eiko (2014)

9

Residência David Libeskind (1961)

Sala de estar 2 (contígua ao bar)

- vista para a área externa e piscina

Foto: Sissy Eiko (2014) 
Residência Joseph Khalil Skaf (1958)

Vista a partir da Sala de Jantar para o Parque do Ibirapuera

Foto: José Moscardi (1958)

11

Residência David Libeskind (1961)

Vista a partir da sala de jantar para volume do escritório e área externa.

Foto: Sissy Eiko (2014)

12

Residência David Libeskind (1961) Vista a partir da sala de jantar para a sala de estar 1 (pé direito duplo), escritório e área externa.

Foto: Sissy Eiko (2014)

13

Residência David Libeskind (1961)

Vista a partir da sala de jantar para a sala de estar 2 .

Foto: Sissy Eiko (2014)

14

Residência Joseph Khalil Skaf (1958)

Pérgola sobre varandas laterais dos dormitórios

Foto: José Moscardi (1958)
Residência Joseph Khalil Skaf (1958)

Elevação frontal a partir da Rua

República do Líbano

Foto: José Moscardi (1958)

16

Residência Natan Faermann (1958)

Sanitário

Foto: José Moscardi (1958)

17

Residência David Libeskind (1961)

Elevação para a Rua Traipu - muro em pedra e ladrilhos

Foto: Bebete Viégas

18

Residência David Libeskind (1961)

Elevação Rua Atibaia - muro de pedra e jardim elevado

Foto: Karen Balsevicius Evangelisti (2014)

19

Residência David Libeskind (1961)

Sala de Estar 1 - lareira e escada

Foto: Karen Balsevicius Evangelisti

(2016)

20

Residência Natan Faermann (1958)

Lareira

Foto: José Moscardi (1958) 
Residência Natan Faermann

(1958)

Iluminação zenital - vista do estar para o vestíbulo em plano elevado

Foto: José Moscardi (1958)

\section{2}

Residência David Libeskind (1961)

Vista a partir da Sala de estar 2 escada e pilar de madeira

Foto: Sissy Eiko (2014)

\section{3}

Residência David Libeskind (1961)

Escritório - painel e móvel de Joaquim Tenreiro

Foto: Sissy Eiko (2014)

\section{4}

Residência David Libeskind (1961)

Vista pata o bar de Joaquim Tenreiro a partir da sala de estar 2 (contígua ao bar), lareira e escada - muros de pedra, piso e forro de madeira

Foto: Karen Balsevicius Evangelisti (2016)

\section{5}

Residência David Libeskind (1961)

Vista a partir do vestíbulo de acesso principal da casa - cota intermediária - Rua Atibaia

Foto: Karen Balsevicius Evangelisti (2016)
Residência Antônio Mauricio da

Rocha (1957)

Acesso principal - vista Rua Itacira

Foto: José Moscardi (1957)

27

Casa Kaufmann, Richard Neutra, Palm Springs, USA. (1947)

Vista externa

Foto: Julius Schulmann

\section{8}

Residência David Libeskind (1961)

Vista interna da sala de jantar mesa e cadeiras de Joaquim Tenreiro

Foto: Sissy Eiko (2014)

\section{9}

Casa Kaufmann, Richard Neutra,

Palm Springs, USA. (1947)

Vista interna da sala de jantar

Foto: Julius Schulmann

\section{0}

Casa Singleton, Richard Neutra, Bel Air, California, USA. (1947)

Vista externa - vigas metálicas

Foto: Julius Schulmann (1960)

\section{1}

Residência David Libeskind (1961)

Vista do muro lateral - área de serviço - painéis em vidro.

Foto: Bebete Viégas 
Residência David Libeskind (1961)

Elevação frontal - Rua Atibaia

Foto: Bebete Viégas

33

Residência David Libeskind (1961)

Elevação da Rua Traipu

Foto: Bebete Viégas

\section{4}

Residência David Libeskind (1961)

Volume da casa a partir da Rua

Traipu

Foto: Bebete Viégas

35

Residência Joseph Khalil Skaf

(1958)

Elevação posterior - varanda da sala de jantar

Foto: José Moscardi (1958)

36

Residência Natan Faermann

(1958)

Desenho da elevação Frontal -

Rua Natingui

Foto: acervo pessoal David

Libeskind
Residência David Libeskind (1961)

Elevação da Rua Atibaia - garagem

- vigas metálicas

Foto: Bebete Viégas

\section{SEGUNDO ATO:}

ARQUITETURA VIVIDA

\section{8}

Residência David Libeskind (1961)

Vestal Reclinada com Pássaro-

Escultura de Vitor Brecheret, déc. 1930

Foto: acervo pessoal de David Libeskind

39

Richard Neutra - Kaufmann House , Palm Springs, USA. (1947)

Vista externa da piscina

Foto: Julius Schulmann

40

Residência David Libeskind (1961)

Vista a partir da sala de estar 2 para área externa (escultura de $\mathrm{V}$. Brecheret - fig.33 ao fundo)

Foto: acervo pessoal de David Libeskind 
Anita Malfatti

Residência David Libeskind (1961)

Antonio Bandeira

Obras de arte - da esquerda para

Antonio Bandeira

a direita:

Bruno Giorgi - escultura em ferro

Francisco Stockinger - escultura

em ferro, madeira e bronze

Oswaldo Goeldi

Foto: acervo pessoal de David

Libeskind

Emiliano Di Cavalcanti

Foto: acervo pessoal de David

Libeskind

\section{2}

Residência David Libeskind (1961)

Obras de arte - da esquerda para

a direita:

Ernesto de Fiori - escultura

Bruno Giorgi - escultura em

bronze

Bruno Giorgi - escultura em

mármore

Em 1․ Plano na foto:

Bruno Giorgi - esculturas em

mármore

Foto: acervo pessoal de David

Libeskind

44

Residência David Libeskind (1961)

Obras de arte - em primeiro plano:

Francisco Stockinger - escultura

em ferro, madeira e bronze

Tela de David Libeskind

Obras de arte - em segundo plano:

Bruno Giorgi - escultura em ferro

Tela de Danilo Di Prete

Foto: acervo pessoal de David

Libeskind

\section{5}

Frank Lloyd Wright - Hotel

Geneva, Lake Geneva, 1911

Lobby fireplace

Foto: Richard Nickel (1967)

\section{3}

46

Residência David Libeskind (1961)

Obras de arte - da esquerda para a

direita, de cima para baixo:

Emiliano Di Cavalcanti

Alberto da Veiga Guignard

José Pancetti

Residência David Libeskind (1961)

Lareira - cerâmicas vitrificadas

- desenho de David Libeskind,

bancos em tronco de vinhático

gema de ovo - Joaquim Tenreiro, escada de acesso ao pavimento do

escritório e área íntima.

José Pancetti

Foto: acervo pessoal de David

Libeskind 
Residência David Libeskind (1961)

Sala de estar 1 (pé direito duplo)

Obras de Arte - da esquerda para

a direita, acima:

Danilo Di Prete

Alberto Burri

Bruno Giorgi - escultura em

mármore (sobre a mesa de centro)

Mobiliário - da esquerda para a

direita:

cadeira de balanço estruturada em

madeira com assento e encosto

em couro, de 1947 e cadeira de

balanço em jacarandá e palhinha

trançada, de 1959, de Joaquim

Tenreiro

duas poltronas "mole" com

estrutura em madeira de lei maciça

torneada, com travessas que

permitem a passagem de percintas

em couro sola que sustentam os

almofadões do assento, do encosto

e dos braços, unidos numa só peça, de 1957, de Sérgio Rodrigues.

Foto: acervo pessoal de David Libeskind

\section{8}

Frank Lloyd Wrigrht - Robbie

House, Chicago, USA, 1908-1910.

Lareira

Foto: James Caulfield, The Wall

Street Journal (2019)
Residência Spartaco Vial (1956)

Desenho da sala de estar

Foto: acervo pessoal de David

Libeskind

50

Residência Edmon Mario Hage

(1966)

Desenho da sala de estar

Foto: acervo pessoal de David

Libeskind

\section{1}

Richard Neutra - Kaufmann House

, Palm Springs, USA. (1947)

Vista do terraço

Foto: Julius Schulman

52

Residência David Libeskind (1961)

Joaquim Tenreiro - porta de acesso

principal

Foto: Sissy Eiko

53

Residência David Libeskind (1961)

Joaquim Tenreiro - painel armário

Foto: Sissy Eiko 
Residência David Libeskind (1961)

Joaquim Tenreiro - guarda-corpo

escada - ligação piso de acesso

(Rua Atibaia para área íntima)

Foto: Sissy Eiko

\section{5}

Residência David Libeskind (1961)

Joaquim Tenreiro - painel do

escritório

Foto: acervo pessoal de David

Libeskind

\section{6}

Residência David Libeskind (1961)

Joaquim Tenreiro - lustre em vidro

Foto: Sissy Eiko

\section{7}

Richard Neutra - Kaufmann House

, Palm Springs, USA. (1947)

Vista sala de estar - elementos verticais

Foto: Julius Schulman

\section{8}

Richard Neutra - Tremaine House

(1961)

Painéis de madeira pivotantes

Foto: Julius Schulman
Residência David Libeskind (1961)

Ateliê (piso inferior) - visor da

piscina

Foto: Sissy Eiko

60

Residência David Libeskind (1961)

Sala de jantar - Joaquim Tenreiro

- lustre em vidro e latão e conjunto de mesa e cadeiras

Foto: acervo pessoal David

Libeskind

\section{1}

Residência David Libeskind (1961)

Joaquim Tenreiro - Luminárias em

vidro e latão

Foto: Sissy Eiko

62

Richard Neutra - Kaufmann House , Palm Springs, USA. (1947)

Vista para painel da sala de estar

Foto: Julius Schulman

\section{3}

Residência David Libeskind (1961)

Primeiro plano: painel de Joaquim

Tenreiro (escritório)

Vista a partir do escritório para vestíbulo e porta principal de acesso (cota Rua Atibaia)

Foto: Karen Balsevicius Evangelisti (2016) 
TERCEIRO ATO:

\section{ARQUITETURA EM TRÂNSITO}

\section{4}

Residência Germinal Ortiz Garcia (1957)

Jardim de inverno - escada de acesso ao piso inferior.

Foto: José Moscardi

65

Capa revista AD - Arquitetura e Decoração n.7 (1956:09/10) ilustração de David Libeskind

Foto: acervo pessoal David Libeskind

66

Residência João Manuel Domingues Perez (1960)

Vista interna do vestíbulo de acesso para porta principal e escada

Foto: José Moscardi

67

Residência João Manuel Domingues Perez (1960)

Vista externa para elevação da Rua Livreiro Saraiva- porta de acesso principal

Foto: José Moscardi
68

Capa revista AD - Arquitetura e

Decoração n.15 (1956:01/02) -

ilustração de David Libeskind

Foto: acervo pessoal David

Libeskind

69

Desenho de Libeskind (década de 1940)

Nanquim sobre papel

Foto: acervo pessoal David Libeskind

70

Capa revista AD - Arquitetura e Decoração n.17 (1956:05/06) ilustração de David Libeskind

Foto: acervo pessoal David Libeskind

\section{1}

Capa Revista Engenharia Mackenzie n. 140 - década de 1950 - ilustração de David Libeskind

Foto: acervo pessoal David Libeskind

\section{2}

Desenho de Libeskind (2012)

Lápis sobre papel

Foto: acervo pessoal David

Libeskind 
Desenho de Libeskind (2012)

Lápis sobre papel

Foto: acervo pessoal David

Libeskind

\section{4}

Residência João Manuel

Domingues Perez (1960)

Vista externa para Rua Livreiro

Saraiva - elementos do paisagismo

Foto: José Moscardi

\section{5}

Pintura de David Libeskind

Exposição Galeria Documenta (1971)

Foto: acervo pessoal David

Libeskind)

\section{6}

Desenho de Libeskind (2012)

Lápis sobre papel

Foto: acervo pessoal David

Libeskind

\section{7}

Capa Revista Engenharia Mackenzie n. 124-5 - década de 1950 ilustração de David Libeskind

Foto: acervo pessoal David Libeskind
Capa Revista Engenharia

Mackenzie n. 129- década

de 1950 - ilustração de David

Libeskind

Foto: acervo pessoal David

Libeskind

79

Residência João Manuel

Domingues Perez (1960)

Detalhe do muro

Foto: José Moscardi

80

Pintura de David Libeskind

Exposição Galeria Documenta (1971)

Foto: acervo pessoal David Libeskind)

\section{1}

Residência Germinal Ortiz Garcia (1957)

Jardim externo

Foto: José Moscardi

82

Pintura de David Libeskind

Década de 1960

Foto: acervo pessoal David

Libeskind 
83

Alberto da Veiga Guignard - Ouro Preto (1955)

Nanquim sobre papel

Acervo Museu Casa Guignard

84

Alberto da Veiga Guignard -

Fantasia sobre Minas Gerais

(1960)

Óleo sobre madeira

Acervo do Museu da Inconfidência

\section{5}

Alberto Burri - Sacking and Red (1954)

Saco e óleo sobre tela

Fondazione Palazzo Albizzini -

Collezione Burri, Città di Castello,

Perugia

86

Alberto Burri - Sack IV (1954)

Saco e óleo sobre tela

Coleção particular de Beatrice

Brandini

87

Residência Spartaco Vial (1956)

Vista para área externa e jardim

Foto: José Moscardi
88

Residência Spartaco Vial (1956)

Vista da elevação a partir da Rua

99 (Sorocaba)

Foto: José Moscardi

89

Residência Germinal Ortiz Garcia

(1957)

Elevação lateral

Foto: José Moscardi

90

Capa para catálogo de S.A.Tubos

Brasilit (década de 1960)- ilustração de David Libeskind

Foto: acervo pessoal David

Libeskind

91

Residência Jankief Zilberkan

(1958)

Viga com aberturas e tratamento do muro

Foto: José Moscardi

\section{2}

Capa revista A Hebraica em Revista (ano VI)-ilustração de

David Libeskind

Foto: acervo pessoal David

Libeskind 
93

Capa revista AD - Arquitetura e Decoração n.11 (1955:05/06) -

ilustração de David Libeskind

Foto: acervo pessoal David Libeskind

\section{4}

Residência Germinal Ortiz Garcia

(1957)

Muro com tratamento de blocos de texturas

Foto: José Moscardi

\section{5}

Capa revista AD - Arquitetura e Decoração n.14 (1955:11/12) ilustração de David Libeskind

Foto: acervo pessoal David Libeskind

\section{6}

Capa Revista Engenharia Mackenzie n. 130- década de 1950 - ilustração de David Libeskind

Foto: acervo pessoal David Libeskind

\section{7}

Jackson Pollock - Number 1 (1949)

Esmalte e pintura metálica sobre tela

The Taft Schreiber Collection

\section{8}

Alberto da Veiga Guignard - Vaso de Flores (1930)

Óleo sobre madeira

Acervo do Museu da Inconfidência

99

Residência David Libeskind (1961)

Vista para o bar com vaso de flores

Foto: acervo pessoal David Libeskind

\section{INTERLÚDIO: A casa vazia ou a morte do arquiteto}

Pg. 187

Alberto da Veiga Guignard - Ouro Preto (1960)

Óleo sobre madeira

Coleção Particular

ÚLTIMO ATO: arquitetura do desenho

\section{Pg. 190}

David Libekind - (2012)

Lápis sobre papel

Foto: acervo pessoal David Libeskind 

BIBLIOGRAFIA 
ÁBALOS, Iñaki. La Buena Vida - visita guiada a las casas de la modernidade. Bar-

celona: Editorial Gustavo Gilli, 2000.

ACAYABA, Marlene Milan. Branco \& Preto - uma história de design brasileiro nos anos 50. São Paulo: Instituto Lina Bo e P. M. Bardi, 1994.

ALDAY, Iñaki \& LLINÀS, José \& LAPEÑA, José Antonio M. \& MONEO, Rafael. Aprendiendo de todas sus casas. Textos i Documents D’Arquitectura. Barcelona: Edicions Universitat Politécnica de Catalunya, 1996.

AMARAL, Aracy. Arte para quê? A Preocupação social na arte brasileira 19301970. São Paulo: Nobel, 1984.

ANDREOLI, Elisabetta \& FORTY, Adrian (org.). Arquitetura Moderna Brasileira. New York: Phaidon Press Limited, 2004.

ARANTES, Otília Beatriz Fiori. O lugar da arquitetura depois dos modernos. São Paulo: Nobel/Edusp, 1993.

\& ARANTES, Paulo. Sentido da Formação. Rio de Janeiro: Paz e Terra, 1997.

ARGAN, Giulio Carlo (1988) Arte Moderna: Do lluminismo aos movimentos contemporâneos. São Paulo: Companhia das Letras, 1992.

Arte e crítica de arte. Lisboa: Estampa, 1995.

História da arte como história da cidade. São Paulo: Martins Fontes, 1992.

(1968) 1.a. ed. História da Arte Italiana: Da Antiguidade a Duccio - v. 1. São Paulo: Cosac \& Naify, 2003.

Projeto e Destino. São Paulo: Ática, 2001.

ARNHEIM, Rudolf. Arte e percepção visual. 5 ed. São Paulo: Pioneira, 1989.

BACHELARD, Gaston. A Poética do Espaço. São Paulo: Martins Fontes, 1993. 
BAKER, Geoffrey H. Le Corbusier. Analisis de La Forma. Editorial Gustavo Gili. Barcelona, $5^{\text {a }}$ edição ampliada, 1994.

BANHAM, Reyner. El brutalismo em arquitectura: ética o estética?. Barcelona: Ed. Gustavo Gili, 1966.

BARDI, Lina Bo. Tempos de Grossura: o design no impasse. São Paulo: Instituto Lina Bo e P. Maria Bardi, 1994.

BARREÑADA, Rafael Diez. Coderch: Variaciones sobre una casa. Colección Arquíthesis 12. Fundación Caja de Arquitectos. Barcelona, 2003.

BENJAMIN, Walter. Illuminations. Edited and with an introduction by Hannan Arendt. New York: Schocken Books, 1931.

Obras Escolhidas: Magia e técnica, arte e política. São Paulo: Brasiliense, 1985.

BERGSON, Henri. Matéria e memoria. 2ed. São Paulo, Martins Fontes, 1999.

BLASER, Werner (1985) Patios - 5000 años de evolución, desde la antigüedad hasta nuestros días. Editorial Gustavo Gili. Barcelona. $2^{a}$ edição, 1999.

BOJUNGA, Cláudio (2001) JK - O artista do impossível. Editora Objetiva. Rio de Janeiro

BOSI, Ecléa. A Casa e outros Poemas. São Paulo: Com-Arte, 2018.

BRASIL, Luciana Tombi. David Libeskind- Ensaio sobre as residências unifamiliares. São Paulo: Romano Guerra Editora/ Edusp. Coleção Olhar Arquitetônico, 2007.

BRUAND, Yves. Arquitetura contemporânea no Brasil. 2. Ed. São Paulo, Perspectiva, 1991.

CAVALCANTI, Carlos. Dicionário Brasileiro de Artistas Plásticos. Rio de Janeiro: INL, 1973. 
CAVALCANTI, Lauro. Quando o Brasil era Moderno: Guia de Arquitetura 1928-

1960. Rio de Janeiro: Aeroplano Editora, 2001.

(org.) Artes Plásticas no Rio de Janeiro: 1905-1960. Rio de Janeiro: Aeroplano Editora, 2001.

CIRLOT, Juan Eduardo. El Arte Otro - Informalismo em la escultura y pintura más recientes. Barcelona: Seix Barral, 1957.

. Informalismo. Barcelona: Editora Omega, 1959.

CIRLOT, Lourdes. La pintura informal en Cataluña, 1951-1970. Barcelona: Anthropos Editorial del Hombre, 1983.

CLARK, Roger H. \& PAUSE, Michael (1996) Arquitectura: Temas de Composición. $3^{a}$ ed. México: Editorial Gustavo Gili, 1997.

COHEN, Jean-Louis. O Futuro da arquitetura desde 1889: Uma história mundial. São Paulo: Cosac Naify, 2013.

COLQUHOUN, Alan. (1989) Modernidade e Tradição Clássica: ensaios sobre arquitetura 1980-87. São Paulo: Editora Cosac \&Naify, 2004.

Postmodernism and Structuralism. Cambridge: MIT Press, 1989.

COMAS, Carlos Eduardo Dias \& ADRIÁ, Miquel. La Casa Latinoamericana Moderna: 20 Paradigmas de mediados del siglo XX. México: Ediciones G. Gili, 2003.

CORNOLDI, Adriano (1988) La Arquitectura de la vivienda unifamiliar. Manual del espacio doméstico. Barcelona: Editorial Gustavo Gili, 1999.

COUTO, Mia. Um rio chamado tempo, uma casa chamada terra. São Paulo: Companhia das Letras, 2003.

CURTIS, William J. R. (1982) Arquitetura Moderna desde 1900. 3a. Ed. Porto Alegre: Bookman, 2008.

DAL CO, Francesco (1985) Mario Botta - Architecture 1960-1985. New York: Electra/Rizzoli, 1987. 
DELEUZE, Gilles. A imagem-tempo. São Paulo: Brasiliense, 1990.

DRILLER, Joachim. Breuer Houses. London: Phaidon Press Limited, 2000.

DURAND, José Carlos. Arte, privilégio e distinção: artes plásticas, arquitetura e classe dirigente no Brasil, 1855 - 1985. São Paulo: Perspectiva, 1989.

ECO, Umberto. Obra Aberta. Barcelona: Ed. Ariel, 1979.

FABRIS, Annateresa (org.). Modernidade e Modernismo no Brasil. Arte: Ensaios e Documentos. Campinas: Ed. Ariel, 1994.

FARIAS, Agnaldo (Ed). Bienal de São Paulo 50 Anos - 1951 2001. São Paulo: Fundação Bienal de São Paulo, 2001.

FERRAZ, Geraldo. Warchavchik e a introdução da arquitetura moderna no Brasil: 1925 a 1940. São Paulo: Museu de Arte de São Paulo, 1965. Prefácio de P. M. Bardi.

FERREIRA, Gloria \& COTRIN, Cecília (orgs.). Escritos de Artistas. Rio de Janeiro: Jorge Zahar Editor, 2007.

FICHER, Sylvia \& ACAYABA, Marlene. Arquitetura Moderna Brasileira. São PauIo: Projeto Editores Associados Ltda., 1982.

FOSTER, Hal. O complexo arte-arquitetura. Sao Paulo: Cosac Naify, 2015.

FRAMPTON, Kenneth (1980) História crítica da arquitetura moderna. São Paulo: Martins Fontes, 1997.

Studies in Tectonic Culture: The Poetics of Construction in Nineteenth and Twentieth Century Architecture. Edited by John Cava. Cambridge, Mass.: Graham Foundation for Advanced Studies and The MIT Press Ltd., 1995.

GIEDION, Sigfried. Space, Time and Architecture: the growth of a new tradition. Cambridge, Massachussets: Harvard University Press, 5 ${ }^{\text {th }}$ ed., 1967.

GOODING, Mel (2001) Arte Abstrata. (Tate Gallery Publishing). São Paulo: Cosac \& Naify Editora, 2002. 
GOODWIN, Philip. Brazil Builds. Architecture new and old 1652-1942. New

York: Museum of Modern Art, 1943.

GREENBERG, Allan \& MAC CORMAC, Richard \& VAN DE BEEK, Johan \& PADOVAN, Richard Espacio Fluido versus Espacio Sistemático. Textos i Documents D’Arquitectura. Barcelona: Edicions UPC, 1995.

GUERRA, Abíilio (org.) Textos fundamentais sobre história da arquitetura moderna brasileira: v2. São Paulo: Romano Guerra, 2010.

HARAGUCHI, Hideaki. A Comparative Analysis of 20 $0^{\text {th }}$-Century Houses. London: Academy Editions, 1988.

HARVEY, David - A Condição pós-moderna. São Paulo: Loyola, 1998.

HAYS, Michael K. Architecture Theory since 1968. Columbia University Graduate School of Architecture, Planning and Preservation, New York. London: The MIT Press, Cambridge, Massachusets, 2000.

HEIDEGGER, Martin. Construir, Habitar, Pensar. Ensaios e conferências. Trad. Márcia Sá Cavalcante Schuback. Petrópolis: Vozes, 2002.

Poetry, Language, Thought. Hofstadter (org.). Nova York: Harper \& Row, 1971.

HEREU, Pere \& MONTANER, Josep M. \& OLIVERAS, Jordi. Textos de Arquitectura de la Modernidad. Madrid: Editorial Nerea, 1994.

HITCHCOCK, Henry-Russell. Frank Lloyd Wright: Obras 1887-1941. Barcelona: Editorial Gustavo Gili S. A., 1982.

(1955) Latin American Architecture Since 1945. New York: The Museum of Modern Art, 1995.

JACKSON, Lesley. Contemporary - Architecture and interiors of the 1950s. London: Phaidon Press, 1994.

JORGE, Luís A. O Desenho da Janela. São Paulo: Annablume editora, 1995. 
JUNQUEIRA, Maria Alice \& ZEIN, Ruth Verde. Brasil, arquiteturas após 1950. São Paulo: Perspectiva, 2010.

KAHN, Louis I. Conversations with students. New York: Rice University School of Architecture, Princeton Architecture Press, 1998.

KAPSTEIN, Glenda. Espaços Intermedios - Respuesta Arquitectonica al Medio Ambiente. Santiago de Chile: Fundación Andes Editorial Universitaria San Francisco, 1998.

KOPP, Anatole (1985). Quando o moderno não era um estilo e sim uma causa. São Paulo: Livraria Nobel, 1990.

LAMPUGNANI, V. M. - org. (1983). Enciclopédia GG de la arquitectura del siglo XX. Editorial Gustavo Gili. Barcelona, 1989.

LASEAU, Paul \& TICE, James. Frank Lloyd Wright - between principle and form. New York: Van Nostrand Reinhold, 1992.

LEACH, Neil. (org). Rethinking Architecture: A reader in cultural theory. London and New York: Routledge, 1997.

LLEÓ, Blanca. Sueño de Habitar. Colección Arquíthesis núm. 3. Barcelona: Fundación Caja de Arquitectos, 1998.

LOURENÇO, Maria Cecília França. Operários da modernidade. São Paulo: Hucitec/ Edusp, 1995.

MALUENDA, Ana Esteban. (ed.) La Arquitectura Moderna em Latinoamérica: Antologia de autores, obras y textos. Estudios Universitarios de Arquitectura n. 27. Barcelona: Editorial Reverté, 2016.

MANGEL, Alberto. Lendo Imagens: uma história de amor e ódio. São Paulo: Companhia das Letras, 2001.

MINDLIN, Henrique E. (1956) Arquitetura Moderna no Brasil. Rio de Janeiro: Aeroplano Editora, 1999. 
MONTANER, Josep Maria. Después del Movimiento Moderno: Arquitectura de la segunda mitad del siglo XX. Barcelona: Editorial Gustavo Gili, 1993.

A modernidade superada: ensaios sobre arquitetura contemporânea. São Paulo: Editora G. Gilli, 2012.

MORAIS, Frederico. Alberto da Veiga Guignard. Rio de Janeiro: Monteiro Soares Editores e Livreiros, 1978.

Panorama das artes plásticas: séculos XIX e XX. 2ª . Ed. rev. São Paulo: Itaú Cultural, 1991.

NESBITT, Kate (Org). Uma nova agenda para a arquitetura: antologia teórica (1965-1995). São Paulo: Cosac \& Naify Editora, 2006.

NEUTRA, Richard. La Natureza y la Vivienda. Barcelona: Ed Gustavo Gili, 1970. El Mundo y La Vivienda. Barcelona: Ed Gustavo Gili, 1962.

OCKMAN, Joan (1993). Architecture Culture 1943 1968: A Documentary Anthology. $2^{\text {nd }}$. Ed. New York: Columbia Books of Architecture, Rizzoli, 1996.

PAREYSON, L. Os problemas da estética. São Paulo: Martins Fontes, 1997.

PEDROSA, Mário. Dos murais de Portinari aos espaços de Brasília. São Paulo: Perspectiva, 1981.

RANCIĖRE, Jacques. Figuras da História. Trad. Fernando Santos, - 1ª ed. São Paulo: Editora Unesp, 2018.

RICHTER, Gerhard. Atlas. Ed.Helmut Friedel. New York: D. A. P. (Distributed Art Publishers), 2006.

RYBCZYNSKI, Witold (1986). La casa: Historia de uma idea. (9ª ed.) Madrid: Nerea Editorial, 2013.

SACRISTE, Eduardo. Que és la casa. Colección Esquemas, Buenos Aires: Editorial Columba, 1968. 
SACK, Manfred (1994). Richard Neutra Editorial Gustavo Gili, Barcelona. $2^{a}$ edição, 1997.

SANTOS, Maria Cecília Loschiavo. Móvel Moderno no Brasil. São Paulo: Editora Senac São Paulo/ Editora Olhares, 2017.

SCHULZ, Norberg (2000). Los pricipios de la arquitectura moderna: sobre la nueva tradición del siglo XX. Estudos Universitarios de Arquitectura. Barcelona: Editora Reverté, S.A. 2005

SCULLY JR., Vincent (1961). Arquitetura Moderna: a arquitetura da democracia. São Paulo: Editora Cosac \& Naify, 2002.

SEGAWA, Hugo. Arquiteturas no Brasil: 1900-1990. 3a. ed. São Paulo: Editora da Universidade de São Paulo, 2018.

\& DOURADO, Guilherme M. Oswaldo Arthur Bratke. São Paulo: Pro-Editores Associados, 1997.

SMITH, Elizabeth A. T. Case Study Houses: 1945 - 1966, l'impulsion californienne. Germany: Taschen, 2006.

STEELE, James \& JENKINS, David. Pierre Koenig. London: Phaidon Press Limited, 1998.

SYKES, A. Krista. O campo ampliado da arquitetura: Antologia Teórica 19932009. São Paulo: Cosac \& Naify, 2013.

TAFURI, Manfredo. Projecto e utopia: arquitetura e desenvolvimento do capitalismo. 1ª ed. Lisboa: Ed. Presença, Coleção Dimensões, 1985.

Teorias e história da arquitetura. São Paulo: Martins Fontes, 1987.

The Sphere and the Labyrinth: Avant-gardes and Architecture from Piranesi to the 1970's. Cambridge, MA: The MIT Press, 1978.

\& DAL CO, Francesco. Modern Architecture. Milão: Electa/Rizzoli, 1986. 
TEYSSOT, Georges. Da Teoria da Arquitetura: doze ensaios. Departamento de Arquitetura da Faculdade de Ciências e Tecnologia da Universidade de Coimbra. Lisboa: Edições 70 Ltda., 2010.

TRIGUEIROS, Luiz. Fernando Távora. Lisboa: Editorial Blau, 1993.

URSPRUNG, Philip; LOPES, Diogo Seixas; BANDEIRA, Pedro. Eduardo Souto de Moura: Atlas de Parede Imagens de Método. Porto: Dafne Editora, 2011.

VASCONCELOS, Sylvio de. Arquitetura no Brasil, pintura Mineira e outros Temas. Belo Horizonte: Edição Escola de Arquitetura, 1959.

VIEIRA, Ivone Luzia. A Escola Guignard na cultura modernista de Minas, 19441963. Pedro Leopoldo, MG: Companhia Empreendimento Sabará, 1988.

XAVIER, Alberto - org.(1987) Arquitetura Moderna Brasileira: Depoimento de uma geração. São Paulo: Editora Pini Ltda. - co-edição ABEA/FVA/PINI, $2^{a}$ edição, 1991.

\& LEMOS, Carlos \& CORONA, Eduardo. Arquitetura Moderna Paulistana. São Paulo: Editora Pini, 1983.

WAISMAN, Marina. O Interior da História: historiografia arquitetônica para uso de latino-americanos. São Paulo: Perspectiva, 2017.

WARBURG, Aby. Atlas Mnemosyne. Trad. Joaquín Chamorro Mielke; Ed. Martin Warnke. Ed Española Fernando Checa. Madrid: Akal, 2010.

WEAVING, Andrew \& FREEDMAN Lisa. Living Modern. São Francisco, Califórnia: Chronicle Books LLC, 2002.

WELSH, John. Modern House. London: Phaidon Press Limited, 1995.

ZABALBEASCOA, Anatxu. As Casas do Século. Lisboa: Editorial Gustavo Gili / Editorial Blau Ltda., 1998. 
ZEVI, Bruno (1951). Saber ver arquitetura. 4a. ed. São Paulo: Editora Martins Fontes, 1994.

ZILIO, Carlos (coord). A Modernidade em Guignard . Pontifícia Universidade Católica. Centro de Ciências Sociais. Departamento de História e Coordenação de Cursos de Extensão. Rio de Janeiro: Lis Gráfica e Editora Ltda., 1983.

ZUMTHOR, Peter. Pensar a arquitetura. Barcelona: Editorial Gustavo Gili, 2009. 

TEXTOS, ARTIGOS, PERIÓDICOS E SITES 
ALBERTO Burri. In: ENCICLOPÉDIA Itaú Cultural de Arte e Cul-

tura Brasileiras. São Paulo: Itaú Cultural, 2019. Disponível em: <http://enciclopedia.itaucultural.org.br/pessoa10707/alberto-burri>. Acesso em: 10 de Fev. 2019. Verbete da Enciclopédia. ISBN: 978-85-7979-060-7

ALMEIDA, Lucia Machado de. Exposição de Guignard em São Paulo. AD - Arquitetura e Decoração, São Paulo, n.13, 1955.

ANDRADE, Mário de. Pintura em Minas - notícia sobre a Escola Municipal. Diário de Notícias, Rio de Janeiro, 29 out. 1944. Apud KLABIN, Vanda Mangia. Op cit.

AZEVEDO, Ricardo M. Tipo e caráter no discurso da arquitetura, Pós. Revista do Programa de Pós-Graduação em Arquitetura e Urbanismo da FAUUSP, 23(7), p. 20-33. São Paulo, 2015.

BAEZA, Alberto Campo. De la materialidad de la Luz. In: Diseño Interior n.38, pp. 04-05. Madrid: Editorial Globus/ Comunicación, 1994.

BAYEUX, Gloria Maria. Debate da arquitetura moderna brasileira nos anos 50. São Paulo: FAU-USP, 1991. (Tese de doutorado).

BRASIL, Luciana Tombi. (2004) David Libeskind- Ensaio sobre as residências unifamiliares. São Paulo: FAU-USP, 2004.

CAMARGO, Monica Junqueira de. Princípios de arquitetura moderna na obra de Oswaldo Bratke. São Paulo: FAUUSP, 2000. (Tese de doutorado).

CASTRO, Amílcar. Apud WORCMAN, Susane. O ensinar de Guignard. In: ZíLIO, Carlos (Org.) A modernidade em Guignard. Rio de Janeiro, Petróleo Ipiranga/ PUC-RJ, 1982.

COLOMINA, Beatriz. Prototipos modernos: la casa norteamericana de posguerra. In: Arquitectura Viva, n.60, pp.23-29. Madrid, 1998.

DANILO Di Prete. In: ENCICLOPÉDIA Itaú Cultural de Arte e Cultura Brasileiras. São Paulo: Itaú Cultural, 2019. Disponível em: 
<http://enciclopedia.itaucultural.org.br/pessoa18751/danilo-di-prete>. Acesso em: 10 de Fev. 2019. Verbete da Enciclopédia. ISBN: 978-85-7979-060-7

FABRIS, Annateresa. Redefinindo o Conceito de Imagem. Revista Brasileira de História. Vol.18, n.35. Escola de Comunicação e Artes - Universidade de São Paulo. São Paulo: 1998.

FERNANDÉZ-GALIANO, Luis. Casas Materiales. In: Arquitectura Viva n.86 [Introdução]. Madrid, 2002.

. "Las formas del informe", Arquitectura Viva n.50. Madrid: 1996.

GIORGI, Bruno. Carta de Bruno Giorgi a Leontina Ribeiro. Carrara, maio, 1970. Arquivo do artista, Rio de Janeiro. Apud GRIMBERG, Piedade. Bruno Giorgi 1905-1993. São Paulo: Metalivros, 2001.

GUIGNARD.In:ENCICLOPÉDIAItaú CulturaldeArteeCulturaBrasileiras.São Paulo: Itaú Cultural, 2019. Disponível em: <http://enciclopedia.itaucultural.org. br/pessoa8669/guignard>.Acessoem:10deFev.2019.VerbetedaEnciclopédia. ISBN: 978-85-7979-060-7

HERBST, Hélio. Promessas e conquistas: arquitetura e modernidade nas Bienais. São Paulo, São Paulo: FAUUSP, 2002. (Dissertação de mestrado).

JOAQUIM Tenreiro. In: ENCICLOPÉDIA Itaú Cultural de Arte e Cultura Brasileiras. São Paulo: Itaú Cultural, 2019. Disponível em: <http://enciclopedia.itaucultural.org.br/pessoa10084/joaquim-tenreiro>. Acesso em: 10 de Fev. 2019. Verbete da Enciclopédia. ISBN: 978-85-7979-060-7

JORGE, Luís A. A arquitetura é um acerto de contas com o lugar. Sistematização crítica da produção acadêmica. São Paulo: FAUUSP, 2016. (Tese de Livre Docência).

KATINSKY, Júlio. Depoimento. In: CONDE, Luiz Paulo; KATINSKY, Julio; PEREIRA, Miguel Alves. Arquitetura brasileira após Brasília - depoimentos. Rio de Janeiro, IAB/RJ, 1978. 
KLABIN, Vanda Mangia. Guignard e a modernidade em Minas. In: ZÍLIO, Car-

los (org.) A modernidade em Guignard. Rio de Janeiro, Petróleo Ipiranga/PUC-RJ, 1982.

LEVI, Rino. Síntese das Artes Plásticas. Acrópole n.192, p. 567-69. São Paulo, 1954.

LIBESKIND, David. Pintura noturna. Veja, São Paulo, n.167, 17 nov. 1971. Seção de Arte, p.104

. Vernissage de David Libeskind. A Gazeta, São Paulo, 03 nov.1971.

Caderno Variedades, p.10.

LIERNUR, Francisco. Nacionalismo y universalidade em la arquitectura latino-americana. In: Modernidad y postmodernidad en América Latina. Colección Historia y teoria latino-americana. Madri: Escala, 1991.

LIRA, José Correia Tavares de. Fraturas da vanguarda em Gregori Warchavchik. São Paulo: FAU-USP, 2008. (Tese de livre-docência).

MARQUES, Maria da Graça O. G. El Arte Matérico hoy. Materias de carga y materiales encontrados. Madrid: Facultad de Bellas Artes, Universidad Complutense, 1994. (Tese de Doutorado).

MARTINS, Carlos Alberto Ferreira. Arquitetura e Estado no Brasil. Elementos para uma discussão da constituição do discurso moderno no Brasil. São Paulo: FFLCH USP, 1988. (Dissertação de mestrado).

MENDONÇA, Denise Xavier de. Arquitetura metropolitana. São Paulo década de 50: análise de 4 edifícios. Copan; sede do Jornal O ESTADO de S. Paulo; Itália; Conjunto Nacional. São Carlos: Escola de Engenharia de São Carlos, USP, 1999. (Dissertação de mestrado)

MERLEAU-PONTY, Maurice. "O olho e o espírito" em textos selecionados da coleção: Os Pensadores, trad. De Marilena Chauí, ed. Abril, São Paulo, 1980.

MEYER, Regina Maria Prosperi (1991) Metrópole e Urbanismo - São Paulo Anos 50. São Paulo: FAU-USP, 1991. (Tese de Doutorado) 
MUSEU Casa Guignard. Nova Exposição de Longa Duração. Ouro Preto, MG: Petrobrás, Governo de Minas Gerias, Secretaria de Estado de Cultura, Superintendência de Museus e Artes Visuais, 2017.

NAVES, Rodrigo. Talvez o maior. Estado de Minas, 22 de junho de1991. P.1

PINI, Sandra Maria Alaga. Documento David Libeskind: a modernidade imanente. Arquitetura e urbanismo - AU, São Paulo, n. 94, 2000, pp.76-81.

RAMÍREZ, Juan Antonio. A contrapelo. El Informalismo como Estilo Internacional. in Arquitectura Viva n.67, p. 66-69. Madrid: Arquitectura Viva, 1999.

RESIDÊNCIA [Antonio Mauricio da Rocha]. Casa e Jardim. São Paulo, n.92, set. 1962, p.28-31.

RESIDÊNCIA [Antonio Mauricio da Rocha]. Acrópole, São Paulo, n.266, dez. 1960, p.58-61.

RESIDÊNCIA em Alto de Pinheiros. [Natan Faermann]. Acrópole, São Paulo, n.275, out. 1961, p.384-386.

RESIDÊNCIA [Germinal Ortiz Garcia]. Casa e Jardim. São Paulo, n.54, jul. 1959, p.4-8.

RESIDÊNCIA [Spartaco Vial] AD - Arquitetura e Decoração. São Paulo, n.5, maio/junho. 1954.

ROWE, Colin e SLUTZKY, Robert. Transparency: Literal and Phenomenal. Perspecta n. 8, 1963, p. 46 [ed. Bras.: "Transparência: Literal e Fenomenal", trad. Leila Vasconcellos, Gávea, n. 2, p. 33-50, 1985].

SALZSTEIN, Sonia. Guignard. São Paulo: Museu Lasar Segal, 1992. Um ponto de vista singular, p.15.

SORIANO, Frederico. Hacia una definición de la planta profunda, de la planta anamórfica y de la planta fluctuante. In: El Croquis n. 81-82, p. 04-13. Madrid: El Croquis Editorial, 1996. 
SPADONI, Francisco. A transição do moderno: Arquitetura Brasileira nos anos 1970. São Paulo: FAUUSP, 2003. (Tese de doutorado).

"Decoração: sobriedade, distinção e acolhimento". Módulo. Rio de Janeiro, 1(2):58-61, Agosto, 1955.

TELLES, Sophia, A arquitetura modernista: um espaço sem lugar. In: Caderno-síntese do $1^{\circ}$ Seminário Nacional de Arquitetura, p. 26-29. Campinas: FAU PUCCAMP, 1984.

VAN EYCK. Aldo. El Interior del tiempo. In: Circo n.37. Madrid: Editado por Luis M. Mansilla, Luis Rojo y Emilio Tuñon, 1996.

VASCONCELLOS, Sylvio de. Inquérito nacional de arquitetura. Jornal do Brasil, Rio de Janeiro, 25 fev., 4,11,18 e 25 mar. 1961. In: XAVIER, Alberto (Org.). Arquitetura moderna brasileira - depoimento de uma geração. São Paulo: Pini/ Abea/FVA/Pini, 1987.

VIEIRA, Ivone Luzia. A obra modernista de Guignard: Inocência poética em questão. www1.cultura.mg.gov.br/museuguignard. 2019.

WAISSMAN, Marina (org). Arquitectura y crítica. Buenos Aires: Summarios, fev./mar., 1977. 


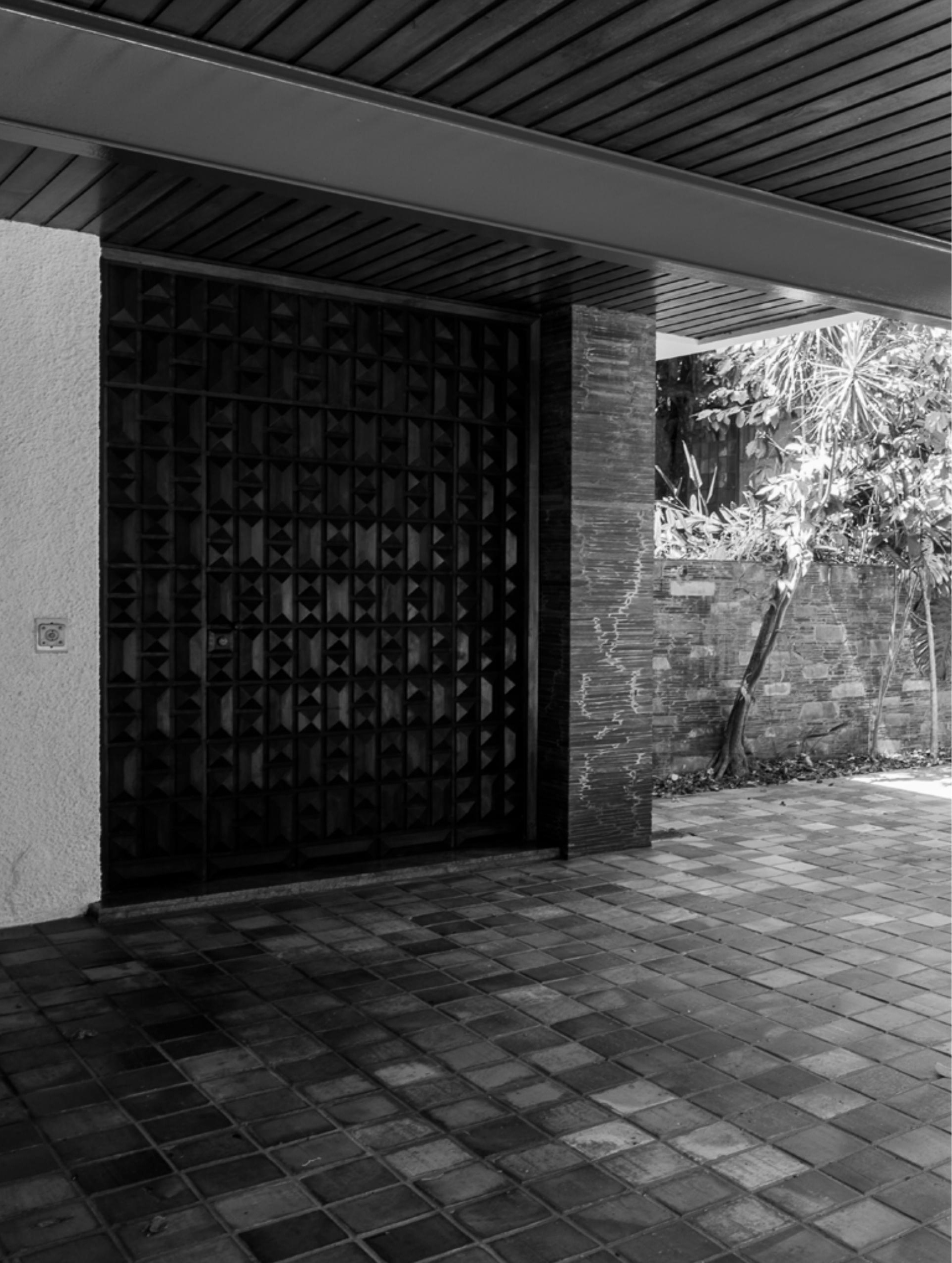


AGRADECIMENTOS 
À Faculdade de Arquitetura e Urbanismo da Universidade de São Paulo - FAU USP.

Ao Prof. Dr. Luís Antônio Jorge,

Minha profunda gratidão, por sua generosidade ímpar e pela inestimável contribuição às ideias apresentadas aqui, sem as quais este trabalho não seria possível.

Aos Profa. Dra. Mônica Junqueira de Camargo e Prof. Dr. Ricardo Marques de Azevedo

Pelas decisivas considerações no exame de qualificação.

Ao Carlos Verna, pelo incentivo constante e pelas conversas que foram fontes renovadas de inspiração.

À Seção técnica de materiais iconográficos da biblioteca da FAUUSP, em especial às meninas da equipe:

Eliana de Azevedo Marques, Dina Uliana, Amarílis Montagnoli Gomes Corrêa, Gisele Ferreira de Brito, Maria Satiko Matsuoka em todo o processo de documentação da obra do arquiteto David Libeskind.

Aos colegas e amigos professores da Faculdade de Arquitetura e Urbanismo da Universidade São Judas Tadeu e da Universidade Mackenzie, pela convivência e pelas reflexões diárias, em especial: Juliana Braga Costa, Eneida de Almeida, Maria Isabel Imbronito e Patrícia Pereira Martins.

À Joana Melo, sempre presente, mesmo na distância.

À Karen Balsevicius Evangelisti e André Scarpa, pelas imagens cedidas.

À Julia Sayeg Tranchesi, pela diagramação.

Ao Marcelo Libeskind, por seu entusiasmo contagiante com o trabalho sobre a obra do seu pai.

Aos meus pais, Ivanilde Tombi Brasil e Evaldo Lins Brasil pelo apoio em todo o processo e por suas presenças tão amorosas. Sem vocês este trabalho não existiria.

À Vitória, pela paciência em me esperar.

Ao David Libeskind (in memorian), pela inspiração. 



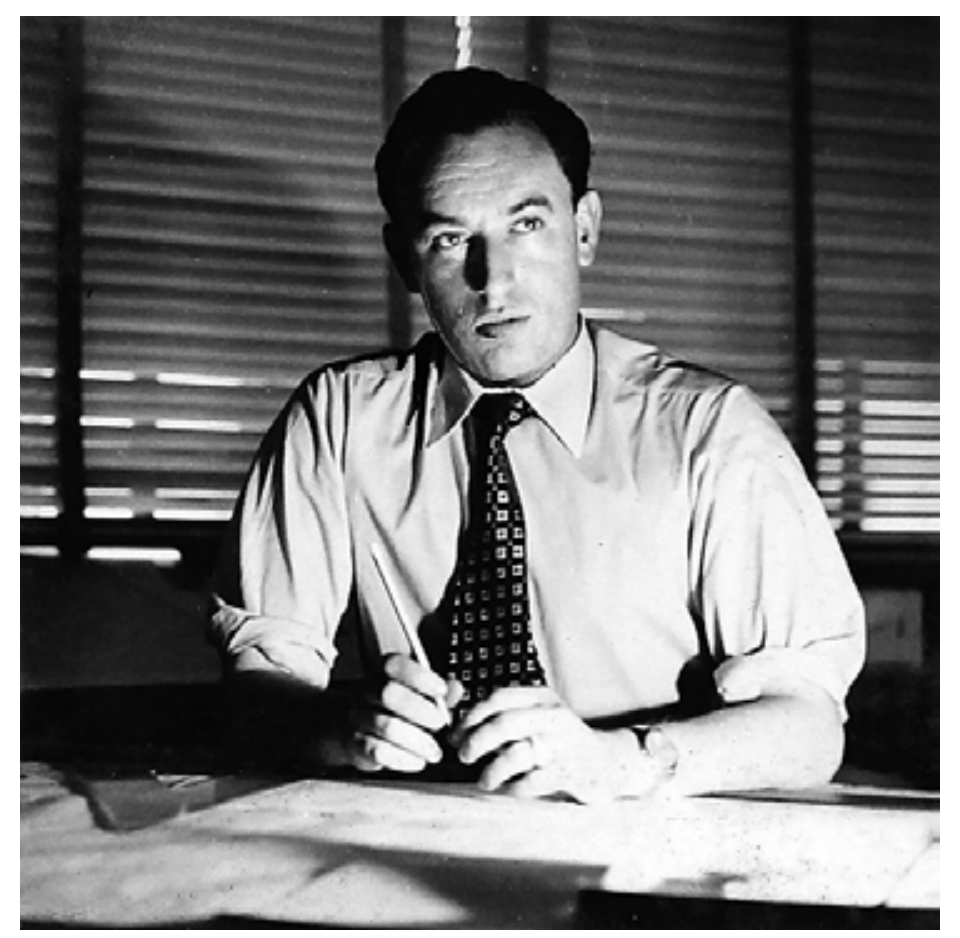

